\title{
De vraag naar diensten van de huisarts
}

Citation for published version (APA):

van der Zee, J. (1982). De vraag naar diensten van de huisarts. [Doctoral Thesis, Maastricht University]. Rijksuniversiteit Limburg. https://doi.org/10.26481/dis.19821203jz

Document status and date:

Published: 01/01/1982

DOI:

10.26481/dis.19821203jz

Document Version:

Publisher's PDF, also known as Version of record

\section{Please check the document version of this publication:}

- A submitted manuscript is the version of the article upon submission and before peer-review. There can be important differences between the submitted version and the official published version of record.

People interested in the research are advised to contact the author for the final version of the publication, or visit the DOI to the publisher's website.

- The final author version and the galley proof are versions of the publication after peer review.

- The final published version features the final layout of the paper including the volume, issue and page numbers.

Link to publication

\footnotetext{
General rights rights.

- You may freely distribute the URL identifying the publication in the public portal. please follow below link for the End User Agreement:

www.umlib.nl/taverne-license

Take down policy

If you believe that this document breaches copyright please contact us at:

repository@maastrichtuniversity.nl

providing details and we will investigate your claim.
}

Copyright and moral rights for the publications made accessible in the public portal are retained by the authors and/or other copyright owners and it is a condition of accessing publications that users recognise and abide by the legal requirements associated with these

- Users may download and print one copy of any publication from the public portal for the purpose of private study or research.

- You may not further distribute the material or use it for any profit-making activity or commercial gain

If the publication is distributed under the terms of Article $25 \mathrm{fa}$ of the Dutch Copyright Act, indicated by the "Taverne" license above, 


\section{DE VRAAG NAAR}

\section{DIENSTEN VAN DE HUISARTS}





\title{
De Vraag naar Diensten van de Huisarts
}

\section{Proefschrift}

ter verkrijging van de graad van doctor in de geneeskunde aan de Rijksuniversiteit Limburg te Maastricht, op gezag van de Rector Magnificus Prof.Dr. H. C. Henker, volgens besluit van het College van Decanen in het openbaar te verdedigen op vrijdag 3 december 1982 , des namiddags om 16,00 uur precies, in de aula van de universiteit

\author{
door
}

Jouke van der Zee

geboren te Amerongen in 1947 
Promotores: Prof.Dr. H. Philipsen

Prof. B. S. Polak

Referenten: Prof.Dr. C. A. de Geus

Prof.Dr. A. Hazewinkel

Het onderzoek dat in dit proefschrift wordt beschreven is uitgevoerd als project van het Nederlands Huisartsen Instituut te Utrecht. 
Omslag, lay-out en tekeningen : M. M. Cornelius, Nederlands Huisartsen Instituut Computergrafieken 


\section{Inhoud}

1. Inleiding en werkwijze

\section{Deel I: Klachten}

2. Inleiding bij deel I

3. De bruikbaarheid van de bevolkingsstudies voor het vaststellen van de vraag naar diensten van de huisarts

3.1. Inleiding

3.2. Enkele bevolkingsstudies

3.2.1. De selectie van de 'bevolking'

3.2.2. Het meten van 'doktersbezoek' 14

3.2.3. De vraagzijde in gezondheidsenquêtes 16

3.2.4. De aanbodzijde in bevolkingsenquêtes 17

3.2.5. De theoretische aanpak en bevolkingsstudies 17

3.3. Kritische kanttekeningen bij bevolkingsstudies 19

3.3.1. Inleiding 19

3.3.2. Kritiek op de vorm van bevolkingsstudies 21

3.3.3. Inhoudelijke kritiek: de dubbelzinnigheid van het verschijnsel 'lichamelijke klachten' 25

3.4. Samenvatting

4. De dubbelzinnige betekenis van lichamelijke klachten 27

4.1. Stress, labiliteit of slechte gezondheid 27

4.2. De klachtenlijst als meetinstrument in de gezondheidszorg 31

4.3. Samenvatting 33 
5. Constructie van een model voor de verklaring wan klachtenscores

5.1. Waarmee hangen klachten samen 34

5.2. Constructie van een model ter verklaring van klachtenscores $\quad 38$

5.2.1. Gezondheidstoestand $\quad 40$

5.2.2. Emotionele labiliteit 43

5.3. Samenvatting en conclusie $\quad 49$

6. Onderzoeksresultaten I; het verklaren van iemands score op een lijst met lichamelijke klachten

6.1. Inleiding 51

6.2. Kunstgrepen. Het probleem der ontbrekende waarden $\quad 52$

6.3. Operationalisering van de variabelen 53

6.3.1. De onafhankelijke variabelen in het model 53

6.3.2. De afhankelijke variabelen in het model 55

6.4. Specificatie van het model $\quad 57$

6.5. Resultaten $\quad 59$

6.5.1. Chronische ziekte 60

6.5.2. Emotionele labiliteit 66

6.5.3. Lichamelijke klachten (de VOEG) 71

6.5.4. De jacht op de 'groene weduwe'; op zoek naar probleemsituaties van jongere gehuwde of altijd ongehuwd geweest zijnde vrouwen - 75

6.6. Samenvatting

7. Samenvatting van deel I

\section{Deel II: Doktersbezoek}

\section{Inleiding}

9. Factoren van invloed op de vraag naar doktersbezoek 96

9.1. Het klachtenmodel 96

9.2. Andere vraagfactoren 98

9.2.1. Klachten van kinderen 98

9.2.2. De invloed van verzekering tegen ziektekosten en inkomensderving 100

9.3. Aanbodfactoren

9.4. Samenvatting

10. Resultaten 2. Eerste contacten, terugbestelcontacten en verwijzen. Gegevens uit de Engelse gezondheidszorg

10.1. Inleiding

10.2. Het Second National Morbidity Survey in Engeland en Wales

10.3. Beschrijuing van het materiaal

10.4. Analyse 
10.4.2. Terugbestellen en verwijzen. Substitutie in de Engelse gezondheidszorg?

10.5. Samenvatting

11. Resultaten 3. Doktersbezoek in het Leef Situatie Onderzoek 1977.

11.1 Inleiding

11.2. Verantwoording van de gebruikte gegevens

11.3. Verwachtingen

11.4. Analyse 1: Wel of niet naar de huisarts

11.5. Analyse 2: Het aantal contacten met de huisarts gegeven het feit dat men eenmaal is geweest

11.6. Doktersbezoek onder verschillende condities

11.7. Samenvatting en conclusie

\section{Samenvatting van deel II}

13. Discussie over de resultaten

13.1. De betekenis van de resultaten voor de constructie van een model woor de Nederlandse gezondheidszorg

13.2. De betekenis van de resulltaten in specifiek-sociaal wetenschappelijke zin

13.3. De maatschappelijke betekenis van de resultaten 162

13.4. Suggesties voor verder onderzoek

14. Summary; The Demand for General Practioner's Services.

\section{Noten}

Hoofdstuk $\mathbb{1}$

177

Deel I

178

Deel II

\section{Literatuur}

Bijlagen

A Schematisch Overzicht van onderzoeksresultaten op het gebied van de verklaring van lichamelijke klachten

B Een hulpmodel voor berekening van de variabele 'sociale status' voor niet-gehuwde en geen beroepsarbeid verrichtende vrouwen

C Enkele niet in de tekst (hfdst. 6) gepresenteerde resultaten ten behoeve wan het construeren van een model ter verklaring van lichamelijke klachten

D Beschrijving van de resultaten van een factor-analyse op de items van de verkarte VOEG 
E Enkelc aanvullende gegevens wit het 2 nd National Morbidity Survey in Engeland en Wales. 1970/71

If Enkele alanwullende gegevens met betrekking tot de analyse van 'medische consumptie" in het Leef Situatie Onderzoek 1977

Dankwoord 


\section{Inleiding en werkwijze}

Hoewel zeker het eerste gedeelte van deze studie als twee druppels water lijkt op een 'gewone' studie naar het verschijnsel 'medische consumptie', zijn er toch enkele belangrijke verschillen met de gebruikelijke aanpak op dit gebied aan te wijzen. Deze verschillen zijn met name het gevolg van het doel waarmee de studie is ondernomen, namelijk het vullen van een leemte in de bestaande modellen die zijn geconstrueerd voor het verklaren van het functioneren wan de gezondheidszorg. De studie is dan ook onderdeel van een serie van studies die met het verschijnen van

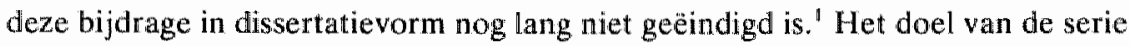
studies (tezamen met B. H. Posthuma gepubliceerd en te publiceren onder de titel: 'Tussen 1e en $2 \mathrm{e}$ echelon') is het ontwerpen van een zo verantwoord en volledig mogeli jk model van de Nederlandse gezondheidszorg.

Met "verantwoord' en "volledig' bedoelen we dat de in de modellen gehanteerde onderstellingen over de gedragingen van de betrokkenen in de gezondheidszorg steunen op onderzoek en theorie.

De maatschappelijke behoefte aan een dergelijk model of aan dergelijke modellen (voor verschillende sectoren van de gezondheidszorg) is groot.

De combinatie van een uitgekiend stelsel van collectieve machtsuitoefening door belanghebbenden èn een neiging tot maximalisatie bij de consumenten maken de beheersing van deze sector tot een weinig dankbare aangelegenheid.

Als men dan ook nog in het duister tast met betrekking tot de oorzaken en gevolgen van de processen die men poogt te beheersen en als zelfs de effecten van bepaalde maatregelen niet of slechts gebrekkig kunnen worden vastgesteld, dan is er sprake van een zekere urgentie voor het wervaardigen van goede evaluatie-instrumenten. De pogingen die daartoe zijn en worden ondernomen, worden echter gehinderd door de volgende factoren:

1. de stand van zaken op theoretisch gebied 
2. (hiermee samenhangend) het meestal gebruikte hoge aggregatieniveau van de modellen.

3. het gebrek aan bruikbare gegevens.

Ad 1.

Niet woor niets worden de gebruikte modellen vaak 'rekenmodellen' genoemd. De inhoudelijke kant is meestal niet de sterkste. Het zijn vaak economen die zich op deze wijze met de gezondheidszorg bezig houden (sociologen zouden het zich overigens wel mogen aantrekken dat ze op dit vlak geheel niet in tel zijn) en zij worden gehandicapt doordat ze in de gezondheidszorg ( $\mathrm{en}$ in andere onderdelen van de 'collectieve sector") met de voor de mark tsector ontwikkelde vraag/aanbodmodellen slecht uit de voeten kunnen.

Vraag en aanbod zijn daar waar de leverancier van diensten de mogelijkheid heeft zijn eigen vraag te scheppen niet van elkaar te onderscheiden, wat tamelijk ingrijpende aanpassingen wan de gebruikelijke theorieën vergt.

\section{Ad 2 .}

De gebruikelijke modellen heten niet alleen 'rekenmodellen', ze worden meestal 'macro-rekenmodellen' genoemd. Het aggregatie-niveau is hoog. Nu is dat op zich zelf geen bezwar; alleen in het geval dat niet goed bekend is hoe de relaties op microniveau zich voltrekken - en dat geldt dan met name voor de wijze waarop en de omstandigheden waaronder dienstverleners hun eigen vraag scheppen - kan men tot onjuiste conclusies komen.

Wil men de dynamiek van de gezondheidszorg goed begrijpen, dan zal men moeten verklaren waarom mensen de hulp van bijvoorbeeld een huisarts inroepen, hoe deze op de hulpvraag reageert (in termen van terugbestellen, medicijnen voorschrijven, verwijzen naar een andere hulpverlener) en wat er verder met de hulpvrager gebeurt (of er bij verwijzing naar een polikliniek een opname volgt etc.) Dergelijke ingewikkelde processen vergen onderzoek op microniveau naar het ontstaan van de behoefte aan hulp, naar het hulpverleningsproces en naar de onderlinge relaties tussen verschillende subsystemen van de gezondheidszorg.

\section{Ad 3.}

Dit laatste houdt meestal in dat nieuwe gegevens moeten worden verzameld; een tijdrovende en wooral kostbare aangelegenheid. Zouden we bijwoorbeeld vraagaanbodrelaties in de huisartsenpraktijk willen bestuderen dan zouden we

a. van een bij een groot aantal huisartsenpraktijken ingeschreven ziekenfonds- en particuliere patiënten moeten weten

1. hoe vaak en met welke klachten ze op eigen initiatief bij de huisarts zijn geweest en hoe vaak ze zijn terugbesteld

2. welke, voor de studie van de vraag naar deze contacten, relevante kenmerken ze bezitter. 
b. de mogelijkheid moeten hebben de werkwijze van de huisarts en wan prakrijkas. sistenten en de wijze waarop de praktijk is georganiseerd te bestuderen.

c. moeten beschikken over een betrouwbare registratie van contacten en verwijzingen over een langere periode.

d. dit alles moeten kunnen bekijken onder verschillende omstandigheden, die van grote invloed zijn op het functioneren van huisartspraktijken (afstand tot en omvang van de specialistisch/medische zorg).

Men kan zich voorstellen dat het verzamelen van dergelijk materiaal een kostbare, tijdrovende en daardoor vrijwel onmogelijke opgave is. Meestal moet men zich baseren op bestaande gegevens. Deze zijn echter sterk afhankelijk van de eigenaardigheden van het systeem van gezondheidszorg. Ook in Nederland is dit het geval. Huisartsen worden per abonnement betaald voor hun ziekenfondspatiënten; hun particuliere patiënten zijn veelal niet voor huisartsenhulp verzekerd, zodat hun rekeningen niet ergens worden gedeclareerd en geadministreerd.

Specialisten en ziekenhuizen kennen daarentegen een tamelijk goed gespecificeerd rekeningenstelsel; vandaar dat over dat gedeelte van de gezondheidszorg veel meer bekend is. Opnamestatistieken van ziekenhuizen, warin de herkomst van alle ziekenhuispatiënten precies bekend is, worden door de Geneeskundige HoofdInspectie voor de volksgezondheid al sinds 1960 vervaardigd. De Stichting Medische Registratie en het Landelijk Informatie Systeem der Ziekenfondsen bezitten tot in aanmerkelijk detail gegevens over de productie van specialisten en ziekenhuizen. Het KISG (het KLOZ (en dat betekent weer Kontaktcommissie Landelijk Overleg van Ziektekostenverzekeraars) Informatie Systeem voor de Gezondheidszorg) dekt helaas nog maar een gedeelte van de door particuliere patiënten ingediende declaraties van ziekenhuisopnamen en specialistenrekeningen, maar ook uit deze sector is voldoende bekend voor het maken van verantwoorde gevolgtrekkingen.

Makers van modellen voor de Nederlandse gezondheidszorg hebben dus meestal well de beschikking over gegevens uit de klinische sector (en zeker voor het gedeelte van de bevolking dat bij de ziekenfondsen is verzekerd); ook nog wel (sinds 1974; het eerste jaar met bruikbare gegevens uit het Landelijk Informatie Systeem der Ziekenfondsen) over verwijscijfers uit huisartspraktijken, maar moeten zich meestal met enkele vooronderstellingen behelpen als het dat gedeelte van de gezondheidszorg betreft dat aan een verwijzing vooraf gaat.

Een zekere (en begrijpelijke) fixatie van onderzoekers op de gevolgen van een verwijzing doet snel vergeten dat verreweg de meeste zaken in de eerstelijnsgezondheidszorg zelf worden afgehandeld. Zelfs een huisarts met een verwijspercentage van 50 of meer op een modale praktijk van 2400 ziekenfondspatiënten schrijft niet meer dan 1200 verwijskaarten per jaar uit. Een respectable aantal, maar alls men beseft dat a) bijna $25 \%$ verwijzingen naar de oogarts betreft, b) een $20 \%$ van de verwijzingen van de specialist zelf afkomstig is - namelijk in de gevallen dat hij de behandeling na een jaar wil continueren-, dan zijn slechts ruwweg 600 
verwijzingen bij zo'n veelverwijzende huisarts als actieve beslissingen te karakteriseren, wat op ongeveer 250 werkdagen en wat weekeinden niet meer dan 2 per dag betekent ${ }^{2}$ De andere contacten ( 30 tot 50 ) worden zelfstandig afgehandeld. Eén verwijzing meer per dag is voor een huisarts een beslissing van 1 op $30,40,50$ contacten, maar betekent een verhoging van het verwijs percentage (het aantal verwijzingen per 100 patiënten) van $20 \%$. In de dagelijkse gebeurtenissen van de huisartspraktijk is 'verwijzen' minder belangrijk dan in de gedachtenwereld van onderzoekers, beleidsmensen en (uiteraard) van specialisten en moeten we ons eerder op "terugbestellen" concentreren en op hetgeen de huisarts zelf voor zijn rekening neemt, dan op het verklaren van het verwijscijfer. ${ }^{3}$

Zoals echter aل gezegd is, ontbreken in de Nederlandse gezondheidszorg op voldoende ruime schaal verzamelde gegevens over de gang wan zaken in de huisartspraktijk. Wèl wordt regelmatig in de bevolkingsenquêtes (zoals in het door het Centraal Bureau voor de Statistiek georganiseerde Leef Situatie Onderzoek gehouden in 1974 en 1977 en de specifieke op de gezondheidszorg gerichte met ingang van 1980 gehouden Gezondheidsenquêtes) aan mensen gevraagd hoe vaak ze contact met de huisarts hebben gehad, of ze in het ziekenhuis opgenomen zijn geweest en of ze lijden aan bepaalde aandoeningen. Deze bevolkingsenquêtes zijn voor ons doel niet in alle opzichten bruikbaar, maar, omdat het meestal grote, landelijk representatieve steekproeven betreft, kan op grond van de resultaten toch nog wel iets gezegd worden over de factoren die de vraag naar diensten wan de huisarts beinvloeden. Voor het gedeelte van onze studie over de vraagzijde zijn bevolkingsenquêtes zeker relevant. Door het ontbreken van op woldoende ruime schaal verrichte praktijkstudies is de aanbodzijde echter in het onderzoek dat de huisartspraktijk als object van belangstelling heeft, slecht belicht.

In de genoemde bevolkingsstudies wordt meestal niet aan de mensen gevraagd hoeveel patiënten hun huisarts heeft of wat voor soort spreekuur hij houdt, of het altijd druk is, enzovoorts. ${ }^{4}$ Het is de vraag of mensen zoiets weten (praktijkgrootte bijvoorbeeld) en als ze het al weten (drukte in de praktijk) zijn onderzoekers er blijkbaar niet zo in geïnteresseerd geweest.

Aangezien we toch iets meer wilden weten over de invloed van een wariabele als de grootte van de huisartspraktijk op de vraag naar diensten van de huisarts, hebben we onze toevlucht genomen tot gegevens die in de. Engelse gezondheidszorg zijn verzameld.

De Engelse gezondheidszorg lijkt in sommige opzichten op de Nederlandse. Zo is de toegang tot de specialistische zorg net als bij ons, via de huisarts gereguleerd. Zo heeft iedere huisarts een omschreven praktijk (patiënten op naam), en wordt hij in een soort abonnementssysteem betaald. ${ }^{5}$ Het grote verschil is dat specialisten in het algemeen in loondienst werken (huisartsen zijn zelfstandige ondernemers, net als bij ons) en dat het verschijnsel "particuliere patiënt" (in de doorsnee-huisartspraktijk) nauwelijks van betekenis is. Bovendien is in de Engelse gezondheidszorg de controle voor de ziektewet in de eerste periode in handen wan de huisarts. 
Geen verrichtingensysteem in de huisartspraktijk en geen vrije toegang van hogere echelons zijn kenmerken die de Engelse en de Nederlandse gezondheidszorg (voor het ziekenfondsgedeelte van de praktijk》 gemeen hebben.

Vandaar dat wij op zoek zijn gegaan naar gegevens uit Engelse huisartspraktijken. Deze gegevens hebben we gevonden in het in 63 Engelse huisartsprakti ken gehouden (tweede) National Morbidity Survey, een samenwerkingsproject van de Research Unit van het Engelse Royal College of General Practitioners (onder leiding van Dr. D. L. Crombie) en het Engelse CBS (Office of Population Censuses and Surveys, OPCS). In de jaren 1970-71 is gedurende een heel jaar lang in deze 63 praktijken een register bijgehouden van alle arts-patiëntcontacten. Een deel van deze gegevens zullen wij gebruiken in ons onderzoek naar factoren die de vraag naar diensten van de huisarts beïnvloeden.

Wij hebben dus de beschikking over twee gegevensbestanden. Het eerste bestand wordt gevormd door de resultaten van het door het CBS in 1977 gehouden Leefsituatie Onderzoek, waarin een belangrijk deel van de vragen gewijd was aan de gezondheidszorg; hierin benadrukken wij vooral de vraagzijde. Het tweede bestand wordt gevormd door gegevens over huisarts-patiëntcontacten uit 1970-71, verzameld gedurende een jaar in 63 Engeise huisartspraktijken uit het 2 nd National Morbidity Survey. Met behulp van dit bestand belichten we de aanbodzijcle met betrekking tot doktersbezoek. Beide bestanden worden in de betreffende hoofdstukken nog uitvoerig beschreven. De lezer dient te beseffen dat het om sub-optimaal onderzoeksmateriaal gaat, dat alleen geschikt is voor het toetsen van een aantal onderstellingen, die wij anders ongetoetst zouden hebben moeten poneren, omdat ieder model voor de Nederlandse gezondheidszorg, dat gebaseerd is op bestaand cijfermateriaal, als het ware 'begint' bij het aantal ziekenfondsverzekerden dat van de huisarts een verwijskaart ontvangt. ${ }^{6}$

\section{Werkwijze}

Bovengenoemde verzamelingen van gegevens (het Leef Situatie Onderzoek 1977 en het tweede National Morbidity Survey) vormen elk de 'pièce de résistance' van een deel van het boek.

Het eerste deel is genaamd 'klachten' en behandelt aan de hand van het Leef Situatie Onderzoek (en na een uitvoerige beschrijving van de literatuur op dit gebied) het voor meer uitleg vatbare begrip 'klagen'; de belangrijkste determinant van doktersbezoek. In deel I proberen we de vraag te beantwoorden wat het betekent als iemand een bepaalde score behaalt, als hem een lijst met lichamelijke klachten voorgelegd wordt.

Deel II gaat over 'doktersbezoek'. In dit deel wordt aan de hand van Engelse gegevens geprobeerd enig zicht te krijgen op de werking van aanbodfactoren en tenslotte proberen we, nadat een aantal aanbodfactoren aan het Leef Situatie Onderzoek is vastgekoppeld, het door de deelnemers aan dit onderzoek opgegeven aantal contacten met de huisarts te verklaren. Onze werkwijze brengt met zich mee 
dat wij ons bij het verklaren van het aantal malen dat iemand de huisarts bezoekt, zullen beperken tot factoren, die zonder al te veel moeite op macroniveau gemeten en verzameld kunnen worden. Dit betreft vooral gegevens die door instanties als het Centraal Bureau voor de Statistiek toegankelijk worden gemaakt voor sociaal-wetenschappelijk onderzoek op macroniveau. 
Deel I: Klachten 



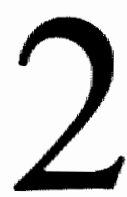

\section{Inleiding bij deel I}

De vraag waarmee we dit hoofdstuk beginnen is: 'In hoeverre zijn bevolkingsenquêtes bruikbaar voor het vaststellen van de vraag naar diensten van de huisarts?' Wij zullen achtereenvolgens bezien

1. of de 'bevolking' overeenkomt met de samenstelling van een huisartspraktijk

2. hoe de vraag naar diensten van de huisarts is vastgesteld

3. wat men zoal aan de vraagzijde meet

4. welke aspecten van de aanbodzijde zijn gemeten.

Naar aanleiding van de kritiek die door Philipsen (1971) destijds en door Mechanic recentelijk (1979) op bevolkingsenquêtes is geuit, zullen we een aantal bevolkingsstudies kritisch bespreken. Onze kritiek heeft vooral betrekking op de manier waarop in dit soort studies 'gezondheid" is gemeten. Meestal is dit gebeurd door mensen een lijst met lichamelijke klachten voor te houden en hun score op deze lijst indicatief te achten voor hun behoefte aan medische hulp. Dit blijkt een dusdanig dubieuze assumptie te zijn, dat onze oorspronkelijke vraag 'zijn bevolkingsstudies bruikbaar voor het vaststellen van de vraag naar diensten van de huisarts' zijn vervolg vindt in een beschouwing over de vraag "watom klagen mensen" on wat is de betekenis wan jemands score op een lijst met lichamelijke klachten. Aan deze twee vragen is het eerste en grootste deel van dit proefschrift gewijd. Doktersbe. zoek komt pas in deel II aan de orde.

Ons betoog verloopt als volgt:

Hoofdsuk 3 hier vragen we ons af of bevolkingsstudies bruikbaar zijn voor het vaststellen van de vraag naar diensten van de huisarts.

Bij onze kritische beschouwing stuiten we op het probleem van de manier waarop in dergelijke studies de 'behoefte aan zorg' is gemeten.

Wij werken dit uit in 
Hoofdsuk 4 waarin 'klachten' centraal staan en we ons afvragen wat deze betekeners.

Nadat we hierover enkele beslissingen hebben genomen geven we in

Hoofdstuk 5 een overzicht van de literatuur waarin verklaring van de variatie in klachtenscores onderwerp van onderzoek is geweest.

De conclusies die we uit deze literatururstudie trekken proberen we te toetsen in

Hoofdstuk 6 waarin we met gegevens uit het Leef Situatie Onderzoek 1977 individuele verschillen in klachtenscores proberen te verklaren.

Tenslotte wolgt in

Hoofdstuk 7 een samenvatting. 


\section{3}

\section{De bruikbaarheid van bevolkingsstudies voor het vaststellen van de vraag naar diensten van de huisarts}

\subsection{Inleiding}

In hoofdstuk 2 is al uiteengezet dat we de vraag naar de bruikbaarheid van bevolkingsstudies voor het waststellen van de vraag naar diensten van de huisarts tamelijk formeel aanpakken. Na het beschrijven van enkele studies (paragraaf 3.2.) bezien we in paragraaf 3.2.1. in welke mate de 'bevolking' in bevolkingsstudies afwijkt van de 'bevolking' van een huisartspraktijk. Daarna (paragraaf 3.2.2.) gaan we na hoe 'doktersbezoek' in deze studies is gemeten, en vervolgens bekijken we in de paragrafen 3.2.3. en 3.2.4. welke factoren aan de vraag-respectievelijk de aanbodzijde in deze enquêtes zijn opgenomen. In paragraaf 3.2 .5 . beschrijven we de theoretische aanpak van de studies. Kritische kanttekeningen bij deze bevolkingsstudies worden gezet in paragraaf 3.3., zowel in formele (paragraaf 3.3.2.) als inhoudelijke (paragraaf 3.3.3.) zin.

Deze inhoudelijke kritiek spitst zich toe op de rol die "lichamelijke klachten" in dit soort onderzoek spelen, maar dan zijn we al weer aan het volgende hoofdstuk toe. Eén opmerking moeten we nog maken; als we spreken over 'vraag' dan hebben we het over de gerealiseerde vraag. Het feitelijk aantal contacten met de huisarts. Alleen in het grote internationale onderzoek van Kohn en White $(1976,171-76)$ wordt nadrukkelijk gevraagd naar gewenste. maar niet gerealiseerde hulp. In alle andere ons bekende studies is het geraliseerde aantal contacten met hulpverleners en instellingen in de gezondheidszorg de operationalisering van de vraag nalar deze zorg. 


\subsection{Enkele bevolkingsstudies}

In Nederland is Gadourek ermee begonnen; aan het eind van de jaren vijftig verzamelde hij zijn materiaal over 'Riskante gewoonten en de zorg voor eigen welzijn" (Gadourek, 1963) door een breed opgezette, representatieve steekproef uit de Nederlandse bevolking te ondervragen over voedings-, rook- en drinkgewoonten, klachten over de toestand van de lichamelijke en geestelijke gezondheid en acties op dit gebied ondernomen: het slikken van al dan niet voorgeschreven geneesmiddelen, bezoek aan huisarts, polikliniek of ziekenhuis en verzuim van school, kantoor of fabriek.

Gadourek's aanpak is, met andere accenten, later nagevolgd. Hijzelf legde de nadruk op 'riskante gewoonten' (een onderwerp dat nu als veell actueler ervaren wordt dan aan het eind van de sobere jaren wijftig); zijn promovendus Aakster (1972) besteedt vooral aandacht aan de door de ondervraagden geuite lichamelijke klachten en de relaties tussen clusters van klachten en een aantal door de respondent in dezelfde klachtenlijst geuite levensproblemen; Cassee (1973) wijkt in zoverre af dat hij zijn uitgebreide vragenlijst (met name aandacht voor de determinanten van doktersbezoek) voorlegt aan een (vergeleken met de landelijke onderzoekingen veel kleinere) in een grote stad gesitueerde steekproef, maar de in 1974 gepubliceerde studie van de Groningse werkgroep onder leiding van J. L. Jessen vertoonde weer cle vertrouwde, brede, landelijk representatieve opzet.

De verzameling van het materiaal voor het merendeel der bovengenoemde studies dateert uit 1968-1970; dat geldt ook voor de grote internationale, onder auspiciën van de WHO uitgevoerde, studie over gezondheidszorg; 'Health Care, an international study", waarvan de uiteindelijke rapportage uit 1976 dateert (Kohn en White, 1976).

Alleen het materiaal werzameld in het kader van het Belgisch Nationaal Onderzoeksprogramma in de Sociale Wetenschappen is van later datum (1976-1977) en is naar verhouding in korte tijd na de verzameling van het materiaal gepubliceerd (Nuyens e.a., 1979, Nuyens, 1981). 'Dit betekent dat de onderzoekers (met uitzondering van de equipe van Nuyens) van elkaars ervaringen niet hebben kunnen leren en dat men (achteraf beschouwd) een aantal gemeenschappelijke kenmerken tegenkomt, waardoor ze minder geschikt zijn om als basis te dienen voor een voorspelling over het aantal personen dat een huisarts dagelijks ziet.

\subsubsection{De selectie van de 'bevolking'}

Om als huisarts in het Register van Huisartsen te worden opgenomen dient men praktijk uit te oefenen voor een patiëntengroep die niet (a priori) eenzijdig mag zijm samengesteld naar leeftijd of geslacht (Huisarts Registratie Commissie, 1981, 54555). Artsen die bijvoorbeeld uitsluitend patiënten uit een verpleeghuis waaraan zij zijn verbonden 'op hun naam hebben staan', vallen niet onder deze omschrijving van 'huisarts". 
Wil men, uitgaande van bevolkingsenquêtes, berekeningen maken over het aantal patiënten dat dagelijks een beroep op de huisarts doet, dan zouden idealiter deze bevolkingsenquêtes een doorsnede van de gehele bevolking moeten bevatten. Dit is echter zelden het geval.

Soms is dat wel begrijpelijk; als men, zoals Aakster, het meegemaakt hebben van bepaalde levensproblemen in verband wil brengen met het uiten van klachten over de gezondheid, dan lijkt het ondervragen van kleine kinderen hierover niet zo zinvol. Aakster legt echter zonder verantwoording de bovengrens bij 65 jaar.

Ook de selectie van Cassee's steekproef uit het Utrechtse bevolkingsregister is, zonder nadere uitleg beperkt tot personen tussen 20 en 65 jaar. Jessen e.a. hanteren wel een onderste leeftijdsgrens ( 16 jaar), maar geen bovengrens. In het CBS-Leefsituatie- Onderzoek is de onderzochte groep 15 jaar of ouder. In het onderzoek wan Nuyens e.a. wordt de steekproeftrekking wel uitvoerig verantwoord (deel $L F$, hfdst. II, 108 e.v.). De onderste grens (15 jaar) wordt pragmatisch vastgesteld (opnemen van lagere leeftijdscategorieën zou een aangepaste vragenlijst vergen), een bovenste grens wordt juist niet vastgesteld, omdat medische consumptie zeer sterk aan leeftijd gebonden is. Alleen in Kohn en White's internationale studie is een aparte vragenlijst voor kinderen geconstrueerd; maar in dit onderzoek werden alle leden van de geselecteerde huishoudens ondervraagd.

In de CBS-gezondheidsenquête worden alle leden wan het huishouden ondervraagd, dan wel wordt gewerkt met zgn. proxy-interviews, vraaggesprekken waarbij één van de huisgenoten, meestal de vrouw des huizes, voor de afwezige gezinsleden de gegevens verschaft.

Naarmate een studie meer bedoeld is om een beschrijvend overzicht van 'medische consumptie' te geven (Kohn en White, Nuyens e.a., Jessen) is het van groter belang dat niet bij voorbaat bepaalde groepen van onderzoek zijn uitgesloten.

Taalproblemen (vreemdelingen, immigranten, ethnische minderheden of in België meertaligheid); bevolking van inrichtingen, tehuizen, gevangenissen; permanent in het buitenland gelegerde militairen - groepen die soms onder een geheel eigen systeem van gezondheidszorg vallen (militairen, studenten), maar soms een beroep doen op de algemene gezondheidszorg ter plaatse - "dit alles zorgt voor een vertekening, die soms wordt onderkend (Nuyens e.a., deel $\mathbf{F}$ 11-121), maar meestal niet eerder wordt geconstateerd dan bij de vergelijking van de kenmerken van respondenten met de samenstelling van de totale bevolking. Met uitzondering van Kohn \& White's studie en de gezondheidsenquette wan het CBS worden individuen

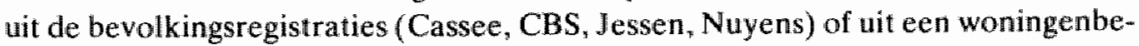
stand (Aakster) getrokken; maar ook in Kohn \& White's onderzoek worden alle gegevens per individu verwerk.t.

De selectie van de bevolking vindt in het algemeen plaats in varianten van de eenvoudige toevalstrekking uit bevolkingsregisters, nadat érst een eerdere, eveneens op toeval gebaseerde steekproef van gemeenten is getrokken (procedure door 
Nass ontworpen woor Gadourek's onderzoek (Gadourek 1963, bijlage)). Bij Jessen is deze procedure exact nagevolgd; Nuyens e.a. stratificeren de steekproef van gemeenten eerst naar urbanisatiegraad en aanbod van voorzieningen. Aakster betrekt zijn steekproef uit een bestaand, representatief, 10.000-woningen tellend woningenbestand, gestratificeerd naar regio en urbanisatiegraad. (Aakster, 1972, 80,81 ). Binnen deze categorieèn is op toevalsbasis een aantall woningen getrokken. Binnen de woningen is het benodigde aantal personen van 25-65 jaar geselecteerd. ${ }^{2}$ Kohn en White's selectie van de 12 onderzoelksgebieden (uit 7 landen) berust op een toevallige samenloop van omstandigheden; bimen de gebieden is de wijze van steekproef trekken afhankelijk van de bestaande wijze van bevolkingsboekhouding of woningregistratie, variërend van een niet meer dan 3 maanden achterlopend register van deelnemers aan een verplichte volksverzekering tegen ziektekosten in Canada tot het via luchtkartering selecteren van groepjes wooneenheden in de Verenigde Staten (Kohn en White, 1976, 28-30).

Samengevat komt het erop neer dat zelfs in onderzoek dat nadruk legt op nationale of regionale representativiteit (b.v. Nuyens' studie of de CBS-Leef-Situatie-Onderzoekingen (niet de gezondheidsenquêtes) een deel van de bevolking wordt uitgesloten. Alleen de internationale studie van Kohn en White probeert het gebruik van de gezondheidszorg wan alle categorieèn individuen te traceren. Van de oudere onderzoekingen zijn zij ook de enigen die huishoudens selecteren en iedereen per huishouden ondervragen. Van de methode waarin één van de leden van het huishouden (meestal de huisvrouw) gegevens verstrekt over het gehele gezin wordt in beperkte mate in de CBS-gezondheidsenquêtes gebruik gemaakt. Nimmer worden. waarnemingen per huishouden gegroepeerd; alle analyses gelden voor individuele personen.

\subsubsection{Het meten van 'doktersbezoek'}

Twee zaken zijn in elk van de genoemde studies te vinden: één of meerdere maten voor het gebruik van voorzieningen en een poging om het oordeel van de ondervraagde over zijn gezondheidstoestand vast te leggen.

Daarnaast heeft elke onderzoeker zo zijn ideeën over de oorzaken van variantie in het vórkomen van beide bovengenoemde verschijnselen, waarmee de rest van het onderzoek is gevuld. Onze belangstelling betreft het gebruik van de diensten van de huisarts. Van bellang zijn:

a. de periode waarop de frequenties betrekking hebben en

b. het onderscheid naar de aard van de contacten (op wiens initiatief, om wat voor reden).

In de genoemde Nederlandse studies werd tot voor kort weinig aandacht besteed aan de periode waarover respondenten nog een betrouwbare weergave van hun contact met de huisarts geven. Cassee en Jessen nemen beiden een periode van 12 maanden (en komen ook op aanzienlijk lagere aantallen uit dan de toen bekende 
landelijke cijfers); Aakster, het CBS-Leef Situatie Onderzoek en de CBS-gezondheidsenquête rekenen met een periode van 3 maanden. In opvallende tegenstelling daarmee staat de periode in Kohn \& White's onderzoek (2 weken voor contact met de huisarts) zonder verantwoording trouwens en de zorgvuldige overweging (Nuyens e.a. dl 1F, hoofdstuk IV, 141-160) in het Belgisch onderzoek van de periode ( 3 maal 3 weken met 3 interviews - als geheugensteun kregen de respondenten een gezondheidsdagboekje).

De Belgische onderzoeksgroep baseert zich vooral op de ervaringen van het Amerikaanse National Health Interview Survey (in een door hen aangehaald papier van P.S. Lawrence (1975)) en op de methode van het Franse CREDOC (Centre de Recherche et de Documentation sur la Consommation). Deze laatstgenoemde instelling heeft een grondige werk wijze. De enquêteresultaten worden aangevuld met de gegevens van het op verrichtingen gebaseerde verzekeringssysteem (Mizrahi \& Mizrahi, 1976, 6).

De keuze van de onderzochte periode is van eminent belang voor de opzet van het onderzoek en voor de mogelijk heden tot analyse van het materiaal; we moeten hier constaterem dat de genoemde Nederlandse onderzoekingen van ouder datum geen exacte betrouwbare gegevens verschaffen en dus alleen gebruikt kunnen worden voor een kwalitatieve analyse van het verschijnsel 'medische consumptie': de gemeten frequenties kunnen ten hoogste beschouwd worden als gemeten op ordinaal niveau.

De lengte van de gekozen periode heeft niet alleen invloed op de betrouwbaarheid van de verkregen gegevens, maar is ook van belang voor de mate waarin men een zinvol verband kan leggen tussen kenmerken op het niveau van het individu (wan welke aard dan ook) en het aantal contacten met bijwoorbeeld de huisarts. Hoe korter de periode, hoe kleiner de kans dat iemand nu net in die periode door een storing in zijn gezondheid getroffen wordt.

Niet altijd is de aard van het contact met de huisarts nader gespecificeerd; Kohn \& White, Nuyens en CBS-gezondheid maken wel onderscheid (vooral tussen contacten op grond wan een klacht over de gezondheid en bijvoorbeeld min of meer verplichte raadplegingen),

Ook worden telefonische contacten in Kohn \& White's studie onderscheiden (meestal betreffen deze herhaal-recepten). In de vier genoemde oudere Nederlandse studies wordt het onderscheid niet gemaakt, in de CBS-gezondheidsenquêtes wel. Wèl wordt goed onderscheiden dan wel nadrukkelijk gevraagd naar de contacten die men voor zichzelf met de dokter heeft.

Het iniriarief tot het contact tenslotte wordt in geen enkele van de genoemde studies vastgelegd, de uitzondering op de regel is ook hier weer de nieuwste CBS-enquête, waarin een aantal recentelijk ontwikkelde, of althans gemeengoed geworden inzichten op theoretisch gebied een verantwoorde vorm hebben gekregen.

Het is immers voor het vaststellen van de vraag naar diensten van de huisarts van groot belang te onderscheiden of het hier een initiatief van de patient of een 
herhalcontact betreft. Voor de laatstgenoemde soort contacten kunnen wij namelijk vraag- en aarbodaspecten niet van elkaar scheiden.

\subsubsection{De vraagzijde in gezondheidsenquêtes}

De sterkste kant van gezondheidsenquêtes is de uitgebreidheid van het aantal vraga-factoren; in de zogenaamde praktijkstudies heeft men veelal slechts de beschikking over enkele achtergrondkenmerken van patiënten: leeftijd, geslacht, verzekeringsvorm en sociale klasse. Zelfs in de minst pretentieus opgezette enquêtes treft men een hele batterij van "achtergrondgegevens" aan (de CBS-gezondheidsenquête telt bijna 40 wragen die erop gericht zijn 'iemands plaats in de samenleving te weten' (enquêteformulier inleiding tot vraag 42)). Dikwijls wordt daarbuiten nog gevraagd naar allerlei opvattingen over ziekte en gezondheidszorg

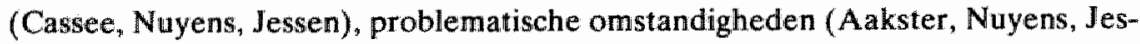
sen, LS077); riskante gewoonten (Gadourek, Aakster, Jessen, Nuyens); het belang van het raadplegen en de steun van de directe sociale omgeving (Cassee, Nuyens) en alles waar de betreffende onderzoeker nog meer belang in stelde.

ledere enquête bevat bovendien een uitgebreide beschrijving van de ervaren gezondheidstoestand.

De methode van ondervraging (we laten hier even de nergens zelfstandig gebruikte 'dagboekmethode' buiten beschouwing) is hier sterk van invloed op het resultaat. Men 'vangt" veel meer klachten als men de respondenten vraagt op een voorgedrukte klachtenlijst aan te geven of men soms, regelmatig of vaak last heeft van alles en nog wat dan als men vraagt 'hoe is het met Uw gezondheid?" en door te vragen "wat scheelt er zoal aan' als de respondent op de eerste vraag antwoordt: 'gaat wel' of "niet best".

Deze laatste methode is gebruikt door Kohn \& White, door Jessen en door Nuyens, soms vult men de op deze wijze verkregen gezondheidsklachten aan met een kort lijstje geprecodeerde klachten; de medewerkers van Kohn en White vroegen door over respiratoire aandoeningen en rheuma-achtige verschijnselen; in het onderzoek van Jessen e.a. werd kort gevraagd naar vijf zeer vaak voorkomende klachten over de gezondheid; Nuyens e.a. maken alleen gebruik van de door de respondent in de drie-weekse periode tussen de vraaggesprekken 'verzamelde' klachten.

In Jessen"s onderzoek wordt overigens wel, apart, een lijst met lichamelijke/niet-lichamelijke klachten opgenomen; de NS (neurotische labiliteit, zich manifesterend in functionele (lichamelijke) klachten) en $N$ (psycho-neurotische klachten)-schalen uit de door Wilde (1963) ontworpen Amsterdamse Biografische Vragenlijst (ABV) (Wilde, 1963, 154).

Cassee en Aakster gebruiken alleen een klachtenlijst; Cassee de door Dirken (1967), ontworpen Vragenlijst voor Onderzoek naar de Ervaren Gezondheidstoestand (de VOEG) en Aakster een zeer uitgebreide, wit verschillende bronnen samengestelde lijst. " Het CBS-Leef Situatie Onderzoek tenslotte vraagt uitwoerig naar de feitelijke toest and van de gezond heid en neemt ook een verkorte versie van 
de reeds genoemde VOEG af. Daarnaast wordt de respondenten gevraagd een algemeen oordeel ower hun gezondheidstoestand te geven, aangevuld met enkele vragen over handicaps, gebreken en chronische kwalen. In de CBS-gezondheidsenquêtes is het onderdeel 'gezondheidstoestand' nog niet operationeel (juni 1982). Soms (zoals in de onderzoekingen van Nuyens en Kohn \& White) worden de geuite klachten met behulp van medici geïnterpreteerd en in (symptoom)-diagnosen omgezet (voor zover dat mogelijk is, want klachten als 'dun bloed" blijven moeilijk classificeerbaar). Reeds genoemd is de Credoc-methode waarin men aanvullende gegevens uit de dossiers van huisarts of specialist verkrijgt.

In geen van de besproken onderzoekingen worden de respondenten medisch onderzocht.

\subsubsection{De aanbodzijde in bevolkingsenquêtes}

Vraag èn aanbod bepalen het gerealiseerde aantal contacten met de huisarts. Op dit laatste gebied schieten de enquêtes echter schromelijk tekort, de uitzondering van de CBS-gezondheidsenquetes daargelaten.

Nu valt het niet aan te nemen dat iemand weet hoe groot de praktijk van zijn huisarts is; heel goed valt echter te vragen (en dat wordt in de nieuwe CBS-enquête ook gedaan) wat voor soort praktijk de huisarts heeft; of het als regel druk is op het spreekuur; of hij een afspraakspreekuur heeft; hoe ver verwijderd de praktijk van het woonhuis van de respondent ligt etc.

Het ontbreken van deze 'aanbodfactoren' maakt de hier besproken gezondheidsenquêtes voor het vaststellen van de vraag naar diensten van de huisarts in feite slechts zeer ten dele bruikbaar.

Soms kiest men een tussenvorm. Men vraagt de respondent niet naar de door hem waargenomen eigenschappen van instellingen en leveranciers van gezondheidszorg, maar brengt op een andere manier gemeten kenmerken van de verschillende ondeydelen van het systeem van gezondheidszorg in verband met de door de respondent opgegeven gedragingen op dit gebied. Zo relateert Nuyens kenmerken van het zorgsysteem van de woonplaats van de respondent aan diens houdingen en gedragingen en koppelen van Vliet en Van de Ven zgn. "aanbodkenmerken" aan de gemeentecode van het Leef Situatie Onderzoek 1977; een werkwijze die ook wij bij de analyse van het LSO-materiaal gevolgd hebben.

Het is echter de vraag (we komen daarop in hoofdstuk 11 nog terug) of juist voor het vaststellen van de vraag naar diensten van de huisarts deze handelwijze geoorloofd is; men kan immers nooit kenmerken van de praktijk van de huisarts van de respondent aan zijn antwoorden vastknopen en men bevindt zich dus eigenlijk op een te hoog aggregatieniveau voor het doen van uitspraken ower de invloed van deze contextuele variabelen.

\subsubsection{De theoretische aanpak in bevolkingsstudies}

De theoretische aanpak in bevolkingsstudies is eenvoudig te omschrijwen. Behalve 
Aakster (1972) die van een systeem-theoretische benadering uitgaat, wordt tot aan de dag van vandaag (Van Vliet en Van de Ven, 1982) uitgegaan van een schema watrin de factoren die doktersbezoek beinvloeden samengebracht worden in drie categorieèn: de noodzaak tot, de behoefte aan en de mogelijkheid tot medische consumptie.

De meeste auteurs (Kohn \& White, Nuyens, Van Vliet en Van de Ven) baseren hun schema op een publicatie van de Amerikaanse socioloog Andersen (1968), die spreekt ower 'predisposing-', 'enabling-' en 'need-'variabelen. Ten onzent was een dergelijk schema reeds lang in gebruik bij de studies naar de achtergronden van het ziekteverzuim (Zie Philipsen, 1969, 38 e.v.), zoals Cassee (1973, 46 e.v.) laat zien. De predisponerende factoren zijn het meest heterogeen; volgens Kohn \& White (hfdst. 4, 42) vallen hieronder demografische kenmerken als leeftijd en geslacht, soort en samenstelling van het huishouden, riskante gewoonten (roken en alcoholgebruik met name), opleiding en houdingen ten opzichte van gezondheid en gezondheidszorg.

De mogelijkheid tot het gebruik maken van gezondheidszorg telt ook verschillende aspecten: afstand tot en omvang van de voorzieningen; wijze van verzekering tegen ziektekosten en/of inkomstenderving bij ziekte en, vooral voor huisvrouwen, opvang wan de werkzaamheden en de hoogte van het gezinsinkomen.

De morbiditeitsgegevens (de consumptie-noodzaak) bevatten de mening over de gezondheidstoestand, de reeds genoemde lichamelijke klachten en chronische aandoeningen en gegevens over dagen in bed en dagen met beperkte activiteiten.

Cassee vindt dat variabelen als leeftijd, geslacht en opleiding niet thuishoren bij de geneigdheids(predisponerende) variabelen; hij noemt ze 'structurele' kenmerken (Cassee, 1973, 46-47) en analyseert ze als aparte categorie.

$\mathrm{Nu}$ is het onderbrengen van variabelen in 'blokken' slechts een eerste aanzet tot modelvorming. Kohn \& White presenteren twee varianten van het 'model'. In het eerste geval hebben de drie blokken een verondersteld onafhankelijke bijdrage (Kohn \& White, 1976, 13-14); in het tweede geval spellen de morbiditeitsvariabelen een belangrijkere rol; ze worden gezien als op hun beurt beinvloed door de andere twee (mogelijkheid en geneigdheid) en beinvloeden zelf het gebruik van voorzieningen. De invloed van de mogelijkheid tot consumptie en de geneigdheid verloopt via de consumptienoodzaak (Kohn en White, 1976, 20, 21). Hoewel enkele opmerkingen wan methodologische aard over de consequentie van deze varianten op pagina 21 worden geplaatst, worden geen andere consequenties voor de analyse getrokken dan dat men de invloed van de verschillende geneigdheids- en mogelijkheidsvariabelen op bijwoorbeeld het contact met de huisarts laat zien onder het constant houden van de ziektevariabelen (partiële gestandaardiseerde regressiecoëfficienten) zie bijvoorbeeld tabel 7.3 op pagina 185). Een soortgelijke oplossing kiest Nuyens' equipe; mogelijke verklaringen van wat zij, ietwat kannibalistisch, noemen "huisartsconsumptie en specialistenconsumptie" worden in 189 meerdimensionale tabellen gepresenteerd; allén voor het gedeelte der respondenten 
$(65 \%)$ met subjectieve gezondheidsklachten (analyse: deel IH $18-94$, pag. 95 226).

Ook in onderzoekingen met een beperkter probleemstelling (bijvoorbeeld de interessante studie die Bice en White (1969) verrichtten ter voorbereiding van het grote internationale WHO-project - of, zoals bij ons de door Mootz (1978, 1980) ondernomen pogingen om consumptieverschillen tussen ziekenfonds ${ }^{-}$en particulier verzekerden te ontdoen van in haar ogen irrelevante coincidenties) wordt vak gekozen voor een aanpak waarin het verband tussen een onafhankelijk geachte variabele en medische consumptie bestudeerd wordt onder constant houden van de gezondheidsklachten (zie ook Jessen, hst. 7, 106 e.v.). Alle auteurs komen na bestudering van de onderzoeksresultaten tot eensluidende conclusies: een van gezondheidstoestand en lichamelijke klachten onafhankelijke bijdrage van ến of meer van de overige variabelen is kennelijk hetzij te verwaarlozen, hetzij incidenteel, hetzij niet interpreteerbaar. ${ }^{4}$

Wat dat aangaat had Philipsen het in $197 \mathrm{~L}$ bij het rechte eind toen hij de resultaten van zijn, bedrijfsgewijze opgezet, onderzoek naar ziekteverzuim vergeleek met Gadourek's onderzoek onder individuele werknemers (Gadourek 1965, Phillipsen 1969,1971 ) en opmerkte dat: 'Als een onderzoeker wil weren warom meneer A van zijn werk wegblijft en meneer $B$ doorwerkt, dan kan men gevoeglijk aanmemen dat meneer A griep heeft en meneer B nier' (Philipsen 1971, 322).

Deze simpele waarheid zal ons uitgangspunt moeten zijn voor een kritische evaluatie van bovengenoemde bevolkingsstudie, zoals we in de volgende paragraaf uiteen zullen zetten.

\subsection{Kritische kanttekeningen bij bevolkingsstudies}

\subsubsection{Inleiding}

David Mechanic (1979) is zeker niet de eerste die een kritische beschouwing wijdt aan wat we gemakshalve maar onder de noemer "bevolkingsstudies" zullen samenvatten. leder die het onderwerp 'medische consumptie' bestudeert kent de kritische literaturstudie van McKinlay (1972) en ook het pleidooi van Jarnes Anderson (1973) om de effecten wan verschillende vormen van gezondheidszorg in een breder perspectief te zien, is op te vatten als een vraagteken bij het nut van de gebruikelijke aanpak in dit veld.

Mechanic echter valt de in vele studies gekozen opzet aan op het meest kwetsbare punt: de resultaten. Onder de veelzeggende titel 'Correlates of Physician Uilizarion": Why do Major Mulivariate Sudies of Physician Utilization Find Trivial Psychosocial and Organizational Effects?" (Mechanic, 1979) vraagt hij zich af hoe het nu komt dat typisch sociologische probleemstellingen zoals de vraag naar de invloed van cultuurgebonden opvattingen over ziekte en gezondheid; participatie in sociale netwerken (het veel geroemde 'lekenverwijssysteem'); de plaats van ziekte 
in het gezin, weliswaar in allerlei onderzoekingen wruchtbaar zijn gebleken maar (voorzover ze al zijn 'meegenomen") van nul en generlei waarde blijken te zijn in de reeds genoemde breed opgezette bevolkingsstudies (Mechanic, 1979, 387)."

Mechanic oppert voor de vorm de mogelijkheid dat al die sociologen zo maar wat hebben beweerd; deze mogelijkheid onderzoekt hij evenwel niet verder en gaat er vanuit dat het probleem ligt in: ${ }^{6}$

1. de manier waarop de onderwerpen in begrippen zijn omgezet;

2. de aard van de gebruikte meetinstrumenten;

3. de manier waarop de gegevens zijn geaggregeerd;

4. de wijze waarop het materiaal is geanalyseerd (Mechanic, 1979, 387).

Mechanic's voornaamste kritiek heeft betrekking op de geldigheidsproblemen, veroorzaakt door de manier waarop 'ziekte' door middel van de vragenlijstmethode gemeten wordt (390-392). Daarnaast levert hij kritiek op de in bevolkingsstudies gangbare 'cross-sectionele' (dwarsdoorsnede) analyses en pleit voor een procesmatige benadering in prospectieve studies.

McKinlay's kritiek is van wat oudere datum (McKinlay, 1972). Hij bespreekt meer dan 350 'utilization studies', onderscheidt een aantal vaak voorkomende problemen, verdeelt de studies in verschillende categorieën (economische, demografische, sociaal geografische, sociaal psychologische, sociaal culturele en organisatie-studies), legt de eerste drie typen studies als te eenzijdig dan wel mechanismeloos terzijde, besteedt veel aandacht aan de laatste drie categorieën en komt tot de volgende aanbevelingen (McKinlay, 1972, 139-40):

1. meer kleinschalige, hypothese-vormende studies;

2. replicatie van oude studies om na te gaan wat de achtergronden van met elkaar strijdige resultaten zijn;

3. ophouden met het analyseren van 'routinely collected records and official statistics* en zelf materiaal verzamelen liefst in prospectieve studies;

4. diepergaand onderzoek doen naar weinig- en veel-gebruikers;

5. afstappen van de analyse van het gedrag van individuen, om in plaats daarvan gezinnen en sociale netwerken tot onderwerp van studie maken;

6. meer aandacht besteden aan de verschillende fasen en stadia van het beslisproces en de wederzijdse definities en perceptie van cliënten en zorgverlenende personen en instellingen?

Beide critici zijn doordrongen van het besef dat procesanalyse, subjectieve definities van gezondheid en ziekte, de rol van de zorgverlenende instanties en van de directe sociale omgeving van bijzonder belang zijn in de studie van het gebruik van voorzieningen in de gezondheidszorg. De kritiek van McKinlay is voornamelijk inhoudelijk van aard en heeft betrekking op een breed scala van studies. Mechanic bekritiseert de voor ons doel belangrijker bevolkingsstudies en concentreert zich (terecht) op het probleem van de lichamelijke klachten.

Onze eigen kritiek op de bevolkingsstudies is voor een belangrijk deel geïnspireerd door en loopt parallel met Mechanic's ideeën; onze voornaamste bijdrage zal zijn 
een poging tot systematisering van de kritiek. Daartoe onderscheiden we een formeel en een inhoudelijk gedeelte. In het laatste deel willen we verder ingaan op de betekenis van de 'klacht' in het onderzoek naar medische consumptie. In het formele, meer methodologische gedeelte willen we proberen de consequenties van de verschillende gebruikte modellen te formuleren.

\subsubsection{Kritiek op de vorm van bevolkingsstudies}

Reeds genoemd als punten van formele kritiek op het gebruik van bevolkingsstudies (surveys) voor het vaststellen van de vraag naar gezondheidszorg en de factoren die deze vraag beïnloeden zijn:

1. bevolkingsstudies omvatten zelden de gehele bevolking (leeftijdsgrenzen bijvoorbeeld beperken de onderzochte groep meestal tot volwassenen);

2. contacten op initiatief van de patiënt en op initiatief van de arts worden in het algemeen niet onderscheiden;

3. er ligt een onderlinge strijdigheid besloten in de eisen die aan de bevolkingsstudie worden gesteld op het vlak van de betrouwbaarheid van de gegevens en wat betreft de zinvolheid van de resultaten.

Hoe korter de bevraagde periode, hoe groter de waarschijnlijkheid dat de antwoorden van de respondent een betrouwbare weergave van zijn ziektegedrag vormen, maar hoe kleiner de kans is dat iemand nu net in die periode getroffen is door een storing in zijn gezondheidstoestand of, het andere uiterste, ten gevolge van een opname in het ziekenhuis zelfs buiten de steekproef valt.

Vraagt men de respondent over een korte periode (twee weken bijvoorbeeld), dan zou zelfs de initiatiefnemer tot het contact met de huisarts nog wel kunnen worden vastgesteld. In de nieuwste CBS-gezondheidsenquête gebeurt dit laatste ook.

Wèl komt men in de problemen als men een verband wil vaststellen tussen min of meer stabiele kenmerken van een persoon (zijn opvattingen over gezondheid, dokters en gezondheidszorg bijvoorbeeld) en het bezoek aan de dokter. Lage of zelfs ontbrekende correlaties zijn te verwachten.

Onderzoekers hebben van verschillende technieken gebruik gemaakt om een acceptabel optimum te vinden tussen bovengenoemde strijdige eisen. Meestal door de periode niet te lang (een jaar) of te kort (twee weken), maar bijvoorbeeld drie maanden te nemen, of soms, zoals in het Belgische onderzoek, door de respondenten gedurende een bepaalde periode een dagboekje als geheugensteun te verstrekken en enkele malen gedurende de (in dit geval negen weken durende) onderzoeksperiode aan de hand van de dagboekjes samen met de respondent onwelbevinden en ziektegedrag over meerdere korte perioden te reconstrueren (zie ook Moll van Charante, 1980).

Het probleem van de lage correlaties valt op te lossen door of daarmee genoegen te nemen òf niet een analyse op individueel niweau maar op geaggregeerd niveau uit te woeren (zie bijvoorbeeld de al genoemde verschillen in uitkomst tussen Gadourek's op individuen gebaseerde onderzoek naar ziekteverzuim en Philipsen's bedrijfsge- 
wijze wergelijking van verzuimcijfers; de factor individuele "vatbaarheid' is dan uitgeschakeld (Philipsen, 1971).

Een dergelijke analyse op geaggregeerd niveau is zelfs noodzaak als men onderstelt dat kenmerken van het aggregaat (in Philipsen's geval; kenmerken van het personeelsbeleid en productieproces wan de door hem onderzochte bedrijven) directe invloed hebben op de frequentie en duur van het ziekteverzuim van individuele werknemers.

Niet relevant in ieder geval is gebleken het produceren van partiële correlaties tussen de relevante onafhankelijke variabelen en doktersbezoek met constant houden van het aantal klachten en aandoeningen. (Philipsen suggereert dit als een van de oplossingen; in Jessen's onderzoek vormt het een belangrijk deel van de rapportage (hst. VII, 121-127) en ook Kohn en White produceren zo hun voornaamste bevindingen).

Deze aanpak suggereert dat de variabele "lichamelijke klachten" een verstorende factor is in de analyse en dat terwijl het ervaren van problemen in de gezondheidstoestand juist een voorwaarde is voor het doktersbezoek. Beter dan de invloed van lichamelijke klachten wit te schakelen lijkt ons een procedure waarin men de a andacht concentreert op het verklaren van de variantie in klachten-scores en vervolgens de variantie in doktersbezoek.

Hoewel het 'noodzaak-mogelijkheid-behoefte-schema' blijkbaar velen aansprak en aanspreekt, is het niet overbodig de herkomst en de constructie van het model nog eens aan een nadere beschouwing te onderwerpen.

In het oorspronkelijke model vormen de 3 groepen variabelen van elkaar onafhankelijke blokken; in schemavorm:

Figuur 3.1.: Het "noodzakelijk-mogelijkheid-behoefte-schema" ter verklaring van de vraag naar diensten van de huisarts.

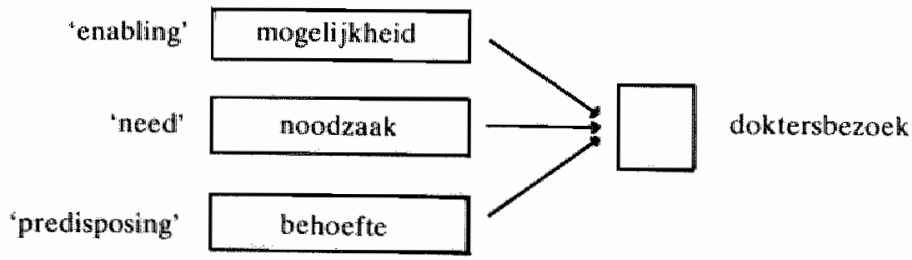

Deze opzet was heel bewust door Andersen en zijn medewwerkers gekozen omdat zij wilden onderzoeken in hoeverre het gebruik van voorzieningen in de Amerikaanse gezondheidszorg loor andere dan noodzakelijkheidsvariabelen werd bepaald. In hun ogen (vandaar ook de titel van Andersen's belangrijkste boek 'Equity in 
Health Services") is er in een systeem van gezondheidszorg van ongelijke kansen sprake als bijvoorbeeld inkomensverschillen tussen mensen meer van het gebruik van voorzieningen verklaren dan verschillen in lichamelijke gezondheidstoestand. In het hoofdstuk 'Health Service Distribution and Equity' (Andersen e.a., 1975, 9 e.v.) stelt hij dat ook met zoveel woorden.

'Equity in Health Services' is dus bereikt als het blok 'need'-variabelen de belangrijkste verklaring voor het gebruik geeft.

Wat in onze ogen dus als een triviaal resultaat wordt beschouwd - 'mensen gaan niet naar de dokter als ze niks hebben' of 'mensen gaan alleen naar de dokter als ze iets mankeren" is in de opvatting van Andersen en zijn medewerkers juist een bevredigende stand van zaken. ${ }^{8}$ Het noodzaak-mogelijkheid- behoefte-schema is bij hen een evaluatie-instrument, een middel om de mate warin de toegang tot de gezondheidszorg rechtvaardig en efficient verdeeld is vast te stellen.

Van deze achtergrond van Andersen's model moet men zich bewust zijn als men zijn aanpak over wil nemen, om niet aan het eind van de analyse met het gevoel te blijven zitten de wetenschap niet veel verder te hebben gebracht. Het schema is niet opgezet als een causaal model ter verklaring van het gebruik van woorzieningen. Andersen heeft echter aan de verwarring rond zijn schema sterk bijgedragen door zelf (in een later stadium) zijn model te transformeren tot een causaal model, waarin de ziekte-variabelen een belangrijkere rol spelen.

In 1978 publiceerden Amdersen en Aday een nieuwe 'gecausaliseerde" versie van hun model, waarin ze ter introductie van het gepresenteerde pad-model stellen, dat:

1. 'the predisposing variables influence utilization through their effects on enabling variables and levels of illness as well as directly;

2. the enabling variables influence utilization directly as well as through the illness variables; and

3. the illness variables have direct effects on utilization (Andersen en Aday, 1978, 535).

Het model ziet er schematisch als volgt uit:

Figuur 3.2: Een aangepaste versie van het noodzaak-mogelijkheid-behoefte-schema ter verklaring van de vragg naar diensten van de huisarts.

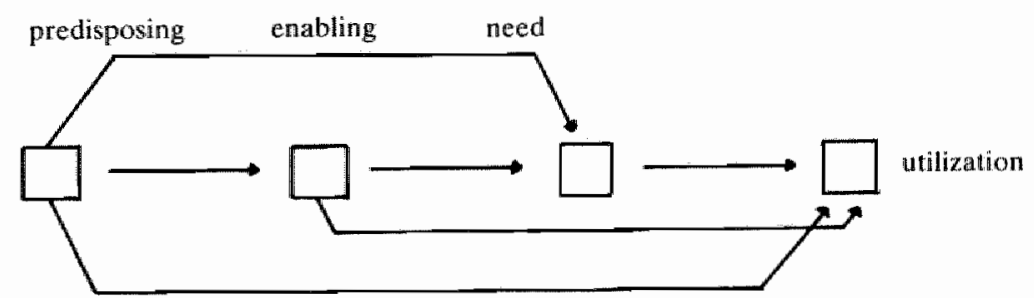


Op pagina 534 stellen de auteurs dat 'gebruik" few eerste afhankelijk is van iemands geneigdheid om dit te doen (zowel zijn socio-demografische kenmerken alls zijn houding ten opzichte van gezondheid, ziekte en gezondheidszorg), vervolgers van zijn mogelijkheid zich te verzekeren van voorzieningen, zoals aangegeven door zijn inkomen, verzekering en beschikbaarheid van die voorzieningen en tenslotte zijn lichamelijke situatie zoals door hemzelf of zijn dokters is vastgesteld. ringen zijn van mijzelf).

De keuze voor een pad-model (in navolging van een dergelijk model op basis van Health Service Interview-gegevens door Wan en Soifer, 1974) wordt nawwelijks nader beargumenteerd.

Min of meer uit het niets verschijnt een (causale) volgordle in een model waarin oorspronkelijk de blokken variabelen niet onderling zijn gerelateerd. Algemeen aanvaarde uitgangspunten voor experimenteel (Selltiz e.a., 1966) of non-experimenteel (Hyman, 1955, Blalock, 1961, Hirschi en Selvin, 1972) sociaal wetenschappelijk onderzoek zijn, dat tussen de verschijnselen A en $B$ sprake is van een causale rellatie als (Hirschi en Selvin, 1972, 126):

1. A aan B vooraf gaat;

2. A en $B$ samen variëren;

3. het verband tussen $A$ en $B$ niet verdwijnt als met het effect van causaal aan $A$ en $B$ voorafgaande variabelen rekening wordt gehouden.

Selltiz e.a. $(1966,80-88)$ en Blalock $(1961,9)$ benadrukken nog de "zinvolle relatie' tussen de twee verschijnselen. Ze moeten in een (theoretisch) netwerk met elkaar verbonden zijn. Zuiver samen variëren in een vast te stellen volgorde is niet voldoende. Willer (1967) spreekt in dit verband over de eis dat modellen van een 'mechanisme' zijn voorzien, opdat duidelijk is langs welke weg de theoretisch relevante begrippen op elkaar inwerken.

Het is wel duidelijk dat bovengenoemde voorwaarden slechts zeer ten dele van toepassing zijn op het 'gecausaliseerde' model van Andersen. Voor de variabelen 'leeftijd' en 'geslacht' laat zich (ook in hun combinaties) nog wel een causaal verband met gezondheidstoestand en gebruik wan voorzieningen in de gezondheidszorg vaststellen; voor alle andere factoren is ofwel de tijdsvolgorde dubieus (gaat een bepaalde houding ten opzichte van gezondheid en gezondheidszorg aan doktersbezoek vooraf of is hij juist het gevolg van iemands ervaringen in de gezondheidszorg), ofwel een empirische relatie afwezig (de samenhangen tussen de opgesomde geneigdheids- en mogelijkheidsvariabelen enerzijds en lichamelijke klachten en gebruik van voorzieningen anderzijds zijn laag) ofwel het theoretische kader zwak ontwikkeld (als het al geëxpliciteerd is).

Een algemene conclusie is dan ook, dat, gegeven het oorspronkelijke doel van Andersen's modellen, waarin niet de wetenschappelijke verklaring van het verschijnsel 'medische consumptie' maar het opsporen van mogelijke ongelijke en onrechtvaardige kanten aan de distributie van woorzieningen centraal stond, de 
transformatie van zijn oorspronkelijk in blokken verdeelde schema van variabelen tot een causaal model niet goed doordacht is en zelfs a priori op deze wije niet mogelijk was.

Desalniettemin heeft Andersen's indeling in consumptie-noodzaak, geneigdheid en mogelijkheid blijkbaar zovele onderzoekers aangesproken door zijn plausibele en directe relatie met de alledaagse ervaringen in de gezondheidszorg, dat zijn schema zeer frequent in ander onderzoek is gebruikt. Een wan de resultaten van dit overnemen (door Andersen zelf gestimuleerd door zijn eigen excercities in later werk) is geweest dat wij Mechanic's vraag "Why do Major Multivariate Studies of Physician Utilization Find Trivial Psychosocial and Organizational Effects' kunnen beantwoorden met: 'Because, originally, those Major Multivariate Studies were Designed to Produce Trivial Results'.

\subsubsection{Inhoudelijke kritek: de dubbelzimnigheid wan het verschijnsel tichamelijke klachten"}

Het tweede bezwaar dat Mechanic tegen de grootschalige surveys naar voren brengt heeft te maken met de wijze waarop in deze onderzoekingen "gezondheid' gemeten wordt. Meestal door de ondervraagde personen een 1 ijst met klachten onder de neus te houdfen en hen te vragen aan te kruisen van welke klachten ze de afgelopen periode last hebben gehad.

Mechanic wijst erop dat dergelijke klachtenlijsten vaak klachten bevatten die eerder naar "psychological distress" verwijzen dan naar lichamelijke ziekte (hoofdpijn, moeheid, malaise) (Mechanic, 1979, 390-92).

Hij concludeert dat 'This reported perception (van de eigen gezondheid JvdZ) seems to be in part learned in childhood, in part shaped by one's location in society and in part conditioned by psychological stress. It is not simply an index of physical health" (Mechanic, 1979,391 ). 10

Mechanic is niet de eerste die dit probleem signaleert; als we ons ewen tot de Nederlandse situatie beperken dan is er al sinds Wilde in 1963 zijn 'Neurotische labiliteit gemeten volgens de vragenlijstmethode" publiceerde en in zijn Amsterdamse Biografische Vragenlijst het uiten wan lichamelijke klachten als een vitaal onderdeel van de neurotische persoonlijkheid beschouwde een cnigszins indirect verlopende discussie ontstaan over de betekenis van (lichamelijke) klachten.

Indirect verlopend omdat (op de moedige poging van Ormel na (Ormel, 1980 a en b) iedere onderzoeker en vragendijst-constructeur $z^{\prime \prime} n$ uitgangspunten nauwelijks ter discussie heeft gesteld. Alleen in een voetnoot, als bijvoorbeeld blijkt dat een met veel moeite geconstrueerde "stress-vragenlijst" (Dirken, 1967, 133); of een algemeen screeningsinstrument woor de geestelijke gezondheid van groepen studenten (Appels, 1975, 172 ) toch een correlatie van .85 met een van de ABV-schalen vertoont, wordt verbaasd opgemerkt dat men zulks niet had verwacht. Bij.jkbar meten "klachten" niet zonder meer iemands gezondheidstoestand en heeft Mechanic gelijk als hij stelt dat er meer aan de hand is. 
Of een klachtenlijst nu alleen 'distress' meet, is overigens evenzeer de wraag. In het volgende hoofdstuk zullen we nader op dit probleem ingan.

\subsection{Samenvatting}

Het belangrijkste bezwaar dat men tegen de bruikbaarheid van bevolkingsenquètes voor het vaststellen van de vraag naar diensten van de huisarts kan aanvoeren, is, dat ze, nast het gegeven dat veelal slechts een selectie (en wel die selectie die zelfstandig tot het beantwoorden van de vragenlijst bereid en in staat is) uit de bevolking wordt ondervraagd, ervan uitgaan dat deze vraag geheel persoonsgebonden is. Zelden of nooit wordt rekening gehouden met het feit dat ook zgn. aanbodfactoren (kenmerken van de huisarts en diens praktijk) een belangrijk deel van de 'medische consumptie" beïnloeden. In ieder geval dat gedeelte van de vraag dat mede op initiatief van de aambieder van de zorg tot stand komt.

Een tweede bezwaar richt zich tegen de theoretische aanpak van het verschijnsel "medische consumptie". Meestal wordt in de bevolkingsstudies een causaal model gehanteerd waarin de 'noodzaak' en de 'mogelijkheid' tot en de 'behoefte' aan het gebruik van voorzieningen in onderlinge samenhang het gebruik zelf beïnvloeden. Dit 'noodzaak-, mogelijkheid-, behoefte-model' is echter beter geschikt (en oorspronkelijk ontworpen) voor het vaststellen van onrechtvaardige en inefficiënte kanten aan de verdeling van de gebruikte voorzieningen dan voor een causale analyse van het gebruik. Er komt namelijk altijd uit (althans in een systeem waar de voorzieningen niet meer schaars zijn) dat de noodzaak tot consumptie het gebruik van voorzieningen bepaalt. Maatschappelijk gezien is dit een belangrijk gegeven; wetenschappelijk leidt dit tot triviale uitspraken. Daarnaast spelen betrouwbaarheidsproblemen een rol. Naarmate men de periode waarover men contacten met de huisarts moet rapporteren korter maakt, neemt de betrouwbaarheid van de antwoorden toe, maar wordt ook de kans op het optreden van een contact, en daarmee de mogelijkheid een zinvol verband te leggen tussen verklarende en te verklaren variabelen, kleiner.

Vergeleken met de zgn. 'praktijkstudies' bieden bevolkingsenquêtes (hoe slecht ze verder ook in elkaar mogen zitten) veel informatie over de situatie waarin de ondervraagden zich bevinden en die aanleiding zijn geweest tot het optreden van onwelbevinden en het raadplegen van de huisarts.

Voor een analyse van die factoren zijn de studies wel bruikbaar - voor het berekenen van het aantal patiënten dat een huisarts, gegeven de samenstelling van zijn praktijk-bevolking, voor $z^{3} n$ loket krijgt, echter niet. 


\section{De dubbelzinnige betekenis van lichamelijke klachten}

\subsection{Stress, labiliteit of slechte gezondheid}

Lijsten waarop mensen kunnen aangeven welke lichamelijke verschijnselen hen hinderen komen, ruwweg gesproken, uit drie verschillende hoeken.

Ten eerste zijn er auteurs (meestal medici) die menen dat men met een klachtenlijst 'ziekte' meet. Bremer en Brouwer (1969) vervaardigden een anamneselijst voor de huisartspraktijk (zie ook Bremer, 1980). Pais (1977) kwam met iets dergelijks voor de (poli)kliniek interne geneeskunde, maar ook Aakster (1972) ging er vamuit dat zijn uitgebreide klachtenlijst verschillende soorten stoornissen in de gezondheid meet en (om de zaak nog ingewik kelder te maken) gebruikte Cassee (1973) de door Dirken (1967) als een maat voor psychobiologische stress ontwikkelde VOEG (Vragenlijst voor Onderzoek naar de Ervaren Gezondheidstoestand) als een mat om de noodzaak (zie het in de vorige paragrafen beschreven schema van Andersen en Philipsen) tot doktersbezoek te indiceren. (Cassee, 1973, 65 e.v.)

De tweede groep onderzoekers is al genoemd; deze gaan ervan wit dat het uiten van (lichamelijke) klachten een maat is voor 'stress'. Dirken (1967) kan men terecht de geestelijke vader van deze benadering noemen. Ook een auteur als Appels (1975), die probeert met zijn Delftse Vragenlijst een algemeen screeningsinstrument voor de geestelijke gezondheidszorg te ontwerpen dat 'aangeefr dat er warschijnlik iets aan de hand is, mat verder niet specificeert wat wa warom dar dam is en dat hort en gemakkelijk is in te wullen en te verwerken" (Appels, 1975. 24), kan men bij deze groep plaatsen.

Zowel Dirken als Appels constateren dat de samenhang tussen VOEG (Dirken) en Delftse Vragenlijst (Appels) en de verschillende sub-schalen van de Amsterdamse Biografische Vragenlijst (ABV) hoog is." Appels merkt hierover op: 'De hoge 
intercorrelatie stelt ook de theoretische vraag hoe het toch kom dat zoveel testen in feite neuroticisme testen blijken te zijn'. (Appels, 1975, 172). ${ }^{12}$

Zo komen wij in het domein van de derde groep auteurs, die menen dat een lijst met lichamelijke klachten 'neuroticisme' meet. ${ }^{13}$ Zij baseren zich, in Nederland althans, op het proefschrift van Wilde $(1963$; in 1970 verscheen een tweede wermeerderde druk op welke uitgave wij ons baseren). ${ }^{14}$ Wilde beschrijft hoe het begrip 'neurotische labiliteit" voor het eerst gemeten is in de Eerste Wereldoorlog (door (Poffenberger) en Woodworth, Wilde, 1970, 24 e.v.) toen men grote aantallen recruten op stabiliteit wilde keuren. Aan de hand van kenmerken van soldaten die na inlijving moeilijkheden vertoonden, is de eerste maat voor emotionele labiliteit geconstrueerd. L. L. en T. G. Thurstone (Thurstone-Thurstone, 1930, aangehaald in Wilde o.c. hst. 3), gebruikten deze gegevens om een vragenlijst te construeren ter opsporing van studenten die psychiatrische aandacht behoefden (Wilde, 1970, 25). Uit deze vragenlijsten zijn honderden andere ontsproten; al stelt Wilde dat 'er praktisch geen neuroticisme-vragenlijst (bestaat) waarin geen vragen woorkomen die geheel of bijna geheel gelijk zijn aan sommige warn die wit 1917' (Wilde, 0.c.,25). Een veel gebruikte schaal is de door Hathaway en McKinley ontworpen MMPI - de Minnesota Multiphasic Personality Inventory uit 500 items bestaand en op empirische gronden geconstrueerd (aan de hand van het onderscheidingsvermogen van de betreffende testen tussen criteriumgroepen). Wilde haalt zijn items uit wan de MMPI afgeleide tests (de Maudsley Personality Inventory en de Two Part Personality Measure (TPPM) van Heron), en besluit een somatische (de ABV-NS) en niet-somatische (de $A B V-N$ ) component als aparte onderdelen van de vragenlijst op te nemen (Wilde, 1970,67). Zijn argumentatie is voor ons verdere betoog niet onbelangrijk. Hij stelt: 'Indien men aam patiënten in medische zin een neurotische labiliteits-vragenlijst voorlegt, watin 'lichamelijke" items zijn opgenomen in de $N$ schaal, dan mag men een kunstmatige ('spurious') verhoging van de $N$-scores verwachen (Gainsburg, 1960, Barendregt, 1961).

In vele gevallen zullen immers de toegediende geneesmiddelen hoofdpijnklachten, duizeligheid, bemacilijkte defaecatie, maagpijn, slapeloosheid, verhoogde rranspiratie en dergelijke met zich meebrengen. Belangrijker is echter dat deze klachten soms behoren tol de fysiologisch, anatomisch, röngenologisch etc. aantoonbare symptomen van de betrokken ziekte en dus wiet zonder meer 'funtioned' te noemen zijn. Als wen patient over hoofdpijn klagat (irem 56 en 23 in de $A B V$ ) dan verliezen deze klachten aan psychologische en winmen aan medische validieit. Deze zelfde items hebben echter geringe medische betekenis bij pariënten die b.v. aan "low back pains" of pinnlijke menstruatie lijden en kunmen dan eerder van psychologische betekenis geacht worden.

Een combinatie van 'somatische' en 'non-somatische' labiliteitsitems die zonder onderscheid in een en dezelfde schaal worden gescoord (zoals bijvoorbedd in de TPPM en de MAS (de Manifest Anxiety Scale, JvdZ) het geval is) leidt dus tor een beperking van het gebruiksgebied wan de test (namelijk tot medisch gezonden) of tot 
een validiteilsvermindering (namelijk onder medisch zieken)'.

Even verderop stelt hij: 'Er is niers geimpliceend op grond wawnan men zou mogen annemen, dat de 'somatische' neuroseklachten meer mer vegetative labiliteit zouden samenhangen dan de nie-lichamelijke neurose-klachten. Wel mag worden werwach dat sommige vegetatief labiele proefpersonen wooral over lichamelik ongemak thagen en dus een hoge NS-score behalen, terwijl andere miet minder autonoom labiele proefpersonen vooral niet-lichamelijke ongemakken rapporteren. De N-schaalen de NS-schaal kunnen beide als operationele definities van het concept neurotische labiliteit worden opgevat'. (Wilde, 1970, 67-68).

Waartoe deze lange citaten? Ten eerste stelt Wilde in zijn bondige schrijtstijl het probleem helder. Ten tweede is het van belang te benadrukken dat de scheiding in wel-en niet-lichamelijke neuroticisme-scores een welbewuste daad wan de auteur is geweest.

Jammer is het dat in de uitgebreide validering van de ABV dit aspect in zijn algemeenheid verwaarloosd is. Wilde heeft nog een aangepaste ABV gemaakt (Wilde 1970, 16-64) voor personen bij wie men neurologische afwijkingen vermoedt, maar de bruikbarkeid van de ABV bij, zoals Wilde dat noemt, "medisch zieken' is nergens onderwerp van toetsing geweest. ${ }^{15}$

In feite doet Wilde de suggestie om de niet-somatische neuroticisme-score te gebruiken als er sprake zou zijn van contaminatie tussen ziekte en emotionele labiliteit.

Het is te betreuren dat hij het bij een a priori onderstelling ( $N$ en NS meten hetzelfde) laat en in zijn uitgebreide valideringsprogramma daar geen aparte aandacht aan heeft gewijd.

De vraag die hij of onderzoekers na hem zich had(den) kunnen stellen is: op welke wijze is wit de ABV-N of NS dan wel uit de VOEG het gedeelte te isolleren dat te maken heeft met een slechte toestand van iemands gezondheid. Gezondheidstoestand dan opgevat als een onafhankelijk van de klachtenscore vastgestelde (liefst tamelijk globale) karakterisering van iemands lichamelijke toestand (hartinfarctpatiënt, suikerzieke, etc.).

Het is dus niet zo dat nooit iemand heeft geconstateerd, dat lijsten met lichamelijke klachten dubbelzinnig wan aard zijn. Wilde's eigen constatering is duidelijk genoeg en ook de conclusie van de auteur van hoofdstuk 7 uit het Groningse onderzoek 'medische consumptie' (Jessen, e.a., 1974, 123) latat aan duidelijkheid niets te wensen over mar er is niet systematisch naar een oplossing van dit probleem gezocht. ${ }^{16}$ Een oplossing kan men zoeken in twee richtingen. In het eerste geval is de aandoening bekend en kan men dit gegeven als criterium beschouwen. In het tweede geval weten we niet of de betrokkene iets mankeert en hebben we alleen de beschikking over een klachten-score. Ook in dit laatste geval zullen we moeten proberen cle typisch gezondheidsgebonden en stress/neuroticismegebonden component te onderscheiden. Kunnen we nu, na de 'historie' van de klachtenlijst wat uitvoeriger te hebben bekeken niet tot een voorlopige slotsom komen? 
Er zijn wel argumenten aan te voeren om de score op een klachtenlijst niet als een maat woor stress, maar voor 'neurotische of emotionele لabiliteit' te beschouwen. Immers,

1. Vragenlijsten die nadrukkelijk zijn ontworpen om 'stress' te meten, zoals Dirken's VOEG en Appels' DV vertonen een verband met de $A B V$, dat dat van 'parallel-tests' benadert. Het is, zoals Appels opmerkt, "net olieboren in Koeweit". Elke poging is raak.

2. Dirken's psychobiologisch stress-begrip boet aan waarde in doordat hij, vrij onverwacht, overschakelt van het in de biologie gehanteerde stressbegrip, waarbij sprake is van intensieve kortdurende stressoren naar langdurige, niet intensieve stressoren (Dirken, 1967,45-47); dit om van de tot dan toe gepresenteerde laboratoriumsituaties over te kumnen schakelen naar stress in het dagelijks leven.

3. Uit het werk van Ormel (1980) wordt duidelijk dat een ABV-neuroticismescore bij personen met een hoge score een zeer stabiel gegeven is. ${ }^{17}$ Scores uit 1970 blijken 6 en 7 jaar later nauwelijks veranderd te zijn. ${ }^{18}$ Of het hier nu om een persoonlijkheidskenmerk gaat of om een kenmerk van een stabiele, onbevredigende situatie, doet er niet zoveel toe; zeker niet als men zich realiseert (zie Ormel's proefschrift, 1980b) dat er nauwelijks een relatie bestaat tussen problemen die iemand niet of nauwelijks in de hand heeft (in Ormel's termen zijn omgevingsgebonden belasting) en zijn neuroticisme-score. Daarentegen is de relatie tussen persoonsgebonden belasting (problemen die voor een belangrijk deel het gevolg zijn van handelingen van de betrokkene) en (iemands 6 jaar eerder gemeten) neuroticisme-score zeer sterk. (Ormel, 1980b, 205-224).

4. Ook de gesommeerde scores van voor medische doeleinden ontworpen klachtenlijsten (Pais" vragenlijst voor de interne kliniek. Bremer en Brouwer's huisartsenanamneselijst (Bremer en Brouwer, 1969, Bremer, 1980), Van der Velden's Algemene Klachten Vragenlijst (v.d. Velden, 1971), Aakster's General Index of Complaints, (Aakster, 1972) moeten als een vergelijkbare maat worden beschouwd. Pais gaat niet op deze mogelijkheid in, maar gebruikt als enige criterium woor de geldigheid van de lijst de sensitiviteit en specificiteit ten opzichte van de dichotomie wel/geen organisch lijden. ${ }^{\prime 9}$ Bremer (en Brouwer) (1969, 1980) bevelen hun van de Cornell Medical Index afgeleide Huisartsen Anamnese Lijst nadrukkelijk aan bij patiënten met functionele klachten. Zij geven echter niet aan hoe deze klachten van op organisch lijden wijzende klachten te onderscheiden zijn. Hun doelstelling is zuiver curatief (Bremer, $1980,53)$.

Van der Velden (1971.) laat een duidelijk verband zien tussen de ABV-N score en het aantal in zijn uitputtende Algemene Klachten Vragenlijst aangekruiste klachten (Van der Velden, 1971, tabel 50, 128) en ook Aakster vindt dat de totaalscore op zijn brede (eigen gemaakte) klachtenlijst sterk samenhangt met de volgende variabelen ("worries" $r=.439(n=1039)$; "neurasthenia" $r=.689$ 
(gecombineerde score voor: hoofdpijn, zenuwachtigheid, duizeligheid en vermoeidheid). (Aakster, 1972, 111-115). Aakster suggereert dat de hoge scores naar een extreme en neurotische antwoordneiging verwijen, en dat juist de "middenscores" op de klachtenlijst een teken zijn van onderscheidbare lichamelijke gebreken. De auteur toont dit laatste echter niet aan.

In Ormel's reeds aangehaalde onderzoek (Ormel, 1980a, b) is het in het licht van de door de auteur beoogde modelconstructie (waarin 'neuroticisme' een verklarende variabele is ten opzichte wan een reeks indices voor onwelbevinden -waronder ook een aantal lichamelijke klachten) van bellang dat neuroticisme enerzijds en een lijst met lichamelijke en psychische klachten anderzijds niet gecontamineerd zijn. Ormel verwijdert uit de oorspronkelijke neuroticisme lijst (zie noot 17) de acht items met de laagste factorladingen, die bovendien, naar zijn zeggen, inhoudelijk het meest op de indices voor onwelbevinden lijken. Niettemin blijven er tenminste 4 parallelle items over. ${ }^{20}$ Ormel komt tot de conclusie, dat zijn lijst met lichamelijke en psychische klachten en de door hem gereduceerde versie van $A B V-N$ en $A B V$ NS naar verschillende begrippen verwijzen op grond van het feit dat de neuroticisme-items enerzijds en de klachten anderzijds op verschillende factoren laden. Beziet men de factorladingen nauwkeurig (bijlage C en D op pagina 347) dan is het de vraag of de auteur bovenstaande conclusie wel had mogen trekken; met evenveel recht kan men tot het 'bestaan' besiuiten van een 'psychische' en een 'lichamelijke' factor, waarin van beide groeperingen ( $k$ lachtenlijst en neuroticisme) de psychische en lichamelijke component op twee afzonderlijke factoren laden. ${ }^{21}$ We mogen wel concluderen dat een lijst met lichamelijke klachten in ieder geval geen 'stress' meet, en waarschijnlijk het best te duiden is als een resultante van emotionele of neurotische labiliteit enerzijds en slechte gezondheid anderzijds. Het is niet zo dat deze twee componenten makkelijk te scheiden zijn. Als men van de psychische (cle $A B V-N$ ) en de somatische (de ABV-NS) component van de ABV probeert de 'soortgenoot-validiteit vast te stellen', zoals de auteurs van het themanummer over de vragenlijstmethode van het Nederlands Tijdschrift woor de Psychologie deden, dan kan men toch nog tot verschillende conclusies komen, afhankelijk bijvoorbeeld wan hat aantal factoren dat men extraheert. Eén auteur (Luteyn, 1980) extraheert vier factoren, een ander drie (Akkerman, 1980). In het eerste gevall laden ABV-N en $A B V-N S$ op verschillende factoren en in het tweede geval samen op én factor. Hoe moeten we de 'labiliteits-' en 'gezondheidscomponent' nu van elkaar scheiden?

\subsection{De klachtenlijst als meetinstrument in de gezondheidszorg}

Wil men met een lijst van lichamelijke en psychische klachten zowel klaaggeneigdheid als gezondheidstoestand meten, dan kan men op verschillende manieren te werk gaan. Het gemakkelijkst is het als men beschikt over een goede karakteristiek van de gezondheid; de aard van de aandoening(en) bijwoorbeeld. Door vergelijking 
van combinaties (clusters) van klachten voor personen met verschillende aandoeningen en vergelijking tussen scores van personen met en zonder aandoening kan men ziekte-specifieke items van algemene 'klaag' items onderscheiden. Op deze wijze onderscheidde Bloos (1972) items voor hartinfarct-patiënten en nierdialysepatiënten in Dirken's VOEG. Een voorwaarde voor een dergelijke techniek is, dat de klachtenlijst voldoende breed van samenstelling is; dat wil zeggen dat de belangrijke klachtengebieden (min of meer parallel lopende met de anatomische tractus: hart/ademhaling (thorax), spijsvertering, bewegingsapparaat, etc. etc.) in de lijst wertegenwoordigd zijn.

Wat dat betreft is de VOEG in zijn volledige vorm al niet ideal (Dirken heeft nadrukkelijk gezocht naar a-specifieke, vegetatieve, dikwijls uit de toxicologie afkomstige klachten) en vertoont de tot 21 items verkorte versie ernstige gebreken op dit gebied. Zo bevat deze verkorte versie vier items die exclusief op maagklachten betrekking hebben en bijvoorbeeld slechts twee vragen over het bewegingsapparaat. Een dergelijke onevenwichtigheid eist zijn tol op het moment dat de lijst bij "medisch zieken" wordt afgenomen; de hoogte van de score krijgt dan iets willekeurigs.

Het is niet waarschijnlijk dat de verkorte VOEG bruikbaar is om ziekte-specifieke items te indiceren - daartoe moet men op z'n minst uitgaan van de complete versie en liefst van een vragenlijst, die zowel "functionele" als orgaan- of ziekte-specifieke klachten bevat.

Reeds genoemd is Aakster's suggestie dat de 'middenscores' op zijn klachtenlijst (en dus op elke soortgelijke lijst) naar een aandoening zouden verwijzen. Aakster geeft hiervoor geen bewijs. Het is ook niet zo voor de hand liggend - of liever gezegd het zou alleen het geval zijn als aandoeningsspecifieke klachten ongecorreleerd zouden zijn met in-specifieke vegetatieve klachten en als "klaaggeneigdheid" niet als een continuüm zou zijn af te beelden, maar alleen door een extreem hoge score gekenmerkt zou worden.

Bloos toont aan dat dit niet het geval is - ook personen met een chronische aandoening of handicap kunnen daar bovenop een zekere neiging tot klagen vertonen. Dat is echter geen regel; men kan zich als het ware ook "beperken" tot de ziekte-specifieke klachten of zelfs helemaal nauwelijks klachten noemen.

Conclusie: Als men alleen de beschikking heeft over een klachtenscore met een beperkte reikwijdte (de verkorte VOEG, een gereduceerde versie van ABV-N of $\mathrm{NS}$ ) en men weet wèl wat de betreffende personen mankeren - dan heeft het niet veel zin on door middel van het opsporen van ziektespecifieke items de scores te corrigeren voor 'gezond heidstoestand'. Men moet dan een model ontwerpen waarin klatage neigdheid of emotionele labiliteit èn gezondheidstoestand een afzonderlijke invloed op de hoogte van de klachtenscore hebben en afzien van nadere specificatie. Voor sociaal epidemiologisch onderzoek verdient een uitgebreide klachtenlijst met een zeg matar 'medische' en een 'functionele' component de voorkeur. Aakster is de enige hierboven vermelde auteur die deze twee componenten nadrukkelijk in zijn 
klachten heeft ingebracht - maar ook de uiteindelijke selectie van zijn items is enigszins duister. ${ }^{22}$

Beschikt men niet over zo'n lijst (en er bestat een sterke neiging om de verkorte versie van de VOEG te gebruiken of hem zelfs tot enkele items nog verder te verkorten (Sikkel, 1980, Jansen en Sikkel, 1981) of weet men niet precies wall de ondervraagde personen mankeren, dan moet men proberen op een globale en niet op een aandoeningsspecifieke wijze beide componenten te onderscheiden.

\subsection{Samenvatting}

De Amerikaanse socioloog David Mechanic heeft zich in een kritische bespreking van de resultaten van de in het vorige hoofdstuk beschreven bevolkingsonderzoeken afgevraagd waarom de onderzoekers steevast als resultaat vinden dat mensen alleen naar de dokter gaan als ze last van iets hebben en waarom alle pogingen om houdingen, meningen, opvattingen en omstandigheden in verband te brengen met doktersbezoek zo weinig opleverden.

Eên van zijn suggesties is, dat de manier waarop in dergelijke studies 'gezondheidstoestand' wordt gemeten (gewoonlijk door mensen op een lijst met klachten te laten aankruisen waar ze weleens last van hebben) heel weinig met 'gezondheid' te maken heeft, maar eerder wijst op, wat hij noemt 'psychological distress' en wat wij met 'spanningsklachten' zouden vertalen.

Naar aanleiding van deze opmerking is de Nederlandse literatuur over dit onderwerp nog eens op een rijtje gezet.

Er blijkt bij psychologen al een vrij lange en gedegen traditie te bestaan om lichamelijke klachten te beschouwen als een kenmerk van een neurotische persoonlijkheid, waarbij de belangrijkste auteur op dit terrein (Wilde) weliswaar goed besefte dat zo'n lijst met lichamelijke klachten ook 'slechte gezondheid' meet, doch volstond met de watschuwing dat men aan 'medisch zieken' een paralleltest, een lijst met psychische, niet-lichamelijke klachten zou moeten voorleggen.

Afgezien van het feit dat velen zich niet aan zijn waarschuwingen hebben gehouden, komt men als onderzoeker in moeilijkheden als men niet weet of iemand ziek is of niet. Bovendien heeft Wilde nooit aangetoond dat 'medisch zieken' niet ook een verhoogde score op een lijst met psychische klachten zouden kunnen hebben.

Wij kunnen hieruit twee dingen concluderen: ten eerste, dat een lijst met lichamelijke klachten zowel 'neurotische of emotionele labiliteit' meet als ook 'slechte gezondheid' en ten tweede dat we moeten proberen beide componenten in zo "n lijst te onderscheiden.

Dat latste zullen we in de volgende hoofdstukken proberen. 


\section{5 \\ Constructie van een model voor de verklaring van klach- tenscores}

\subsection{Waarmee hangen klachten samen}

Hoewel het uiten van lichamelijke en psychische klachten vaak onderwerp van onderzoek is geweest, is er toch niet zo veel bekend over het verband tussen achtergrondkenmerken en klachtenscores.

Dit heeft diverse oorzaken. Ten eerste zijn lichamelijke klachten in de meeste bevolkingsstudies van sociologische makelij als een afzonderlijke, op onafhankelijke wijze de medische consumptie beïnvloedende categorie beschouwd (zie onze bespreking van het consumptiemodel van Andersen paragraaf 3.3.2.) Veel interesse voor de factoren die op hun beurt weer de klachten beïnvloeden is er bij deze auteurs niet. Ook in de gevallen waarin men Andersen's model in een versie presenteert waarbij de klachtenscore niet als exogeen wordt beschouwd, volstaat men met vermelding van enkele terloopse relaties. Een zelfde (begrijpelijk) gebrek aan belangstelling vindt men bij de medici, die van een klachtenlijst gebruik maken (bij hen gat het om het opsporen van individuele en unieke combinaties van klachten), bij een auteur als Dirken, die vooral geînteresseerd is in de invloed van specifieke werkomstandigheden (lawaai, gevaarlijke stoffen, ploegendienst) op de lichamelijke klachten van industrie-arbeiders en bij de auteurs met een psychologische achtergrond, die als constructeurs of gebruikers van een persoonlijkheidstest welhaast per definitie niet in verderliggende achtergronden zijn geïnteresseerd. Alleen 'biografische' variabelen willen nog wel eens de revue passeren.

Alleen bij degenen die, hetzij in de epidemiologie en het woorkomen van 'psychische stoornissen' (van welke stoornissen neuroticisme een onderdeel vormt; in ons land de school van de Groningse sociaal psychiater Giel; in Engeland het werk van Goldberg en anderen) hetzij in de verklaring van het verschijnsel 'klachten' zijn geinteresseerd (in ons land het werk van Aakster, 1972, en Nijhof, 1979) vinden wij 
gegevens waarop we ons verder kunnen oriënteren.

Wij hebben de onderzoekingen bij elkaar gezet in bijlage $A_{\text {; }}$ een gedetailleerde beschrijving in de tekst zou teveel ruimte in beslag nemen.

Van de in bijlage A opgenomen onderzoekingen is vermeld: tijdstip, aantal en soort onderwraagde personen, soort klachtenlijst, gevonden relaties, bivariaat of multivariaat en indien multivariaat, onder constant houden van welke andere variabelen, soort verband (product moment correlatie, gestandaardiseerde partiële regressiecoefficiënt). De noten 23-30 hebben betrekking op de in de bijlage beschreven onderzoekingen.

De meeste relaties zijn bivariaat weergegeven, ondanks de in de meeste studies gebruikte multivariate analysetechnieken. Dit komt omdat deze laatstgenoemde technieken alleen dan relevant zijn als ze in grote lijnen voor het beantwoorden van dezelfde vraagstelling zijn gebruikt. Dit is, zoals al is uitgelegd, zelden of nooit het geval. Verklaring van klachtenscores is zelden een zelfstandig onderwerp van onderzoek en als het verschijnsel at bestudeerd wordt in een aan onze aampak verwant kader, dan zijn er weer andere factoren die een interpretatie van de resultaten moeilijk maken. Zo neemt Aakster variabelen op die wij niet als noodzatkelijk voorafgaand aan de klachten zouden beschouwen (piekeren, affectieve dissatisfactie); en heeft bijvoorbeeld de studie van Pommer en Van Pragg 'satisfactie' als onderwerp. In het geval van de door Nuyens' groep gepresenteerde analyses zijn 'ziektegeschiedenis' en 'chronische aandoening" vaste condities waaronder de andere verbanden worden bezien.

Dit heeft ook ten gevolge dat de auteurs (een uitzondering als Nuyens daargelaten) niet erg gespitst zijn geweest op interactie-effecten van leeftijd, geslacht, burgerlijke staat, wel/niet actief werkzaam. Meestal is of een enkelvoudige relatie berekend, of zijn de variabelen in bijvoorbeeld een multiple regressie of partieel correlatiemodel gebracht, waar de invloed van de variabelen onder constant houden van de overige in het model opgenomen wariabelen wordt bestudeerd. Een methode, die niet erg geschikt is om interactie tussen onafhankelijke variabelen op te sporen.

Resulraten (zie Bijlage A)

Allereerst bezien we de algemene biografische variabelen: leeftijd, geslacht, sociale status (c.q. opleiding, beroepsprestige, inkomen) en burgerlijke staat. Een relatie met "geslacht" vinden vrijwel alle auteurs. Vrouwen hebben hogere klachtenscores dan mannen; dit geldt zowel voor de lijsten met lichamelijke als met niet-lichamelijke klachten. Alleen Cassee vermeld het ontbreken van een verband tussen VOEG-score en geslacht. In het reeds elders uitvoerig besproken pad-model van Andersen en Aday ontbreekt de variabele 'geslacht'. Nijhof (1979) doet zijn onderzoek alleen onder mannen.

Leefrijd vertoont een minder duidelijk verband. Cassee, Jessen, Ormel, Aakster, vinden geen relatie. Pommer en Van Praag alleen een zwak positief verband tussen leeftijd en VOEG-score. Nijhof vindt een (zwak) verband met ABV-NS en VOEG 
en niet met de overige klachtenlijsten. Alle auteurs doen onderzoek onder personen die terminste 15-20 jaar oud zijn.

Nuyens treft bij wrouwen meer klachten aan als ze ouder dan 50 zijn en bij mannen juist minder. Bij Arrindell klagen jongeren meer dan ouderen. Deze laatstgenoemde resultaten statan in sterke tegenstelling tot de door Andersen en Aday gevonden

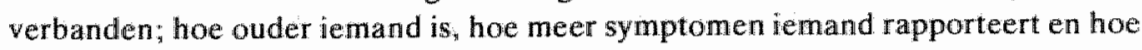
negatiever het totaalbeeld van zijn gezondheid is.

Opleiding, sociale status, inkomen. Nijhof's onderzoek is exclusief aan de relatie tussen sociaal economische status (sociale ongelijkheid) en het woorkomen van psychische stoormissen gewijd. Zijn vier indicatoren woor SES (beroepsstatus vader, beroepsstatus, hoogte opleiding, inkomen) hangen bij de door hem onderzochte populatie (ziekenfondspatiënten van 5 Rotterdamse huisartsen) zwak samen met de door hem gebruikte klachtenlijsten (Nijhof, 1979, 95). De sterkste relatie geeft inkomen bij mannen tussen 20 en 50 jaar. De meeste verbanden verdwijnen als men partiële correlaties berekent met gezondheidstoestand. " Interpretatie van Nijhof's resultaten is niet eenvoudig omdat hij om niet geheel navoelbare redenen de variantie in zijn onafhankelijke variabele (status) sterk beperkt heeft tot de laagste status-categorieën zonder daar bijvoorbeeld nadere verfijningen binnen deze categorieën aan te brengen (in dit geval het verschil tussen havenwerkers en andere industrie-arbeiders bijvoorbeeld).

Jessen, Ormel, Aakster vinden geen verband. Cassee vindt: hoe lager de opleiding, hoe hoger de VOEG. Pommer en Van Praag vinden dat ook, zij het sterker voor de $A B V-N$ dan voor de VOEG. Nuyens vindt daarentegen dat, gegeven geslacht, leeftijd, ziektegeschiedenis en chronische aandoeningen mensen met een hogere opleiding meer klagen; bij Andersen en Aday hebben mensen met een hogere opleiding een hogere klachtenscore. Let well, het betreft hier (behalve bij Nuyens) enkelvoudige verbanden. Ter verklaring wan een negatieve relatie wordt gewezen op de in een slechte gezondheid resulterende maatschappelijke deprivatie; bij een positief verband wordt gewezen op de grotere mondigheid (tenslotte is "klagen" ook de mond open doen) van mensen met meer opleiding.

Burgerlikke staat. Geen van de auteurs besteedt veel aandacht aan de mogelijke invloed van "burgerlijke staat" op gezondheid en welbevinden. Cassee neemt de variabele niet op, evenmin als Aakster en Nijhof; Jessen e.a. vinden een zwak verband tussen al dan niet gehuwd zijn en de klachtenscores (met ABV-N een correlatie van -. 10 met ABV-NS een correlatie van-.06); bij Ormel is een correlatie afwezig. Ook Pommer en Van Praag treffen zeer zwakke verbanden (gescheiden personen $\mathrm{ABV}-\mathrm{N} \mathrm{r}=07$; weduwschap met $\mathrm{ABV}-\mathrm{N} \mathrm{r}=.09$ ). Nuyens vindt dat niet-gehuwden meer klachten rapporteren.

Als men een verband windt is dat in het algemeen zeer $z$ wak; het is ook niet duidelijk of hier van een slechtere geestelijke dan wel lichamelijke gezondheid sprake is. Gezordheidstoestand. Zowell Jessen als. Pommer van Van Praag vonden een verband tussen 'chronische aandoening' of 'langdurige aandoening' en ABV-NS (Jes- 
sen) en VOEG en ABV-N (Pommer en Van Praag). Men moet met een dergelijk verband voorzichtig zijn; het is alleen van belang als gezondheidstoestand en klachtenscore niet gecontamineerd zijn.

Met name de in het CBS-leefsituatie survey gebruikte indlicator 'langdurige aandoening' voldoet niet erg aan deze voorwaarde. ${ }^{32}$

Nijhof vindt $(1979,282)$ hoge correlaties tussen de variabele 'gezondheidstoestand' VOEG, ABV-NS en de Langner-schaal met algemene psychiatrische stoornissen ( $\mathrm{r}$ resp. $.43, .39$ en $.36 \mathrm{n}=1544$ ). Het wordt echter uit zijn boek niet duidelijk hoe deze variabele precies is gemeten; alleen word vermeld dat het hier het eigen oordeel van de respondent betreft.

Overige variabelen. In Ormel's onderzoek is werken/riet werken een belangrijke factor. Het probleem bij deze mat is dat ook personen die krachtens de Wet op de Arbeids Ongeschiktheid geen werkzaamheden meer verrichten meegeteld zijn. Contaminatie met 'chronische aandoening' ligt hier voor de hand. Aakster vindt nog een verband tussen 'sociale mobiliteit' en de klachtenscore en een verband met "desintegratie ouderlijk gezin".

In het SCP-cahier is nog de relatie tussen 'sociale isolatie' en met name de ABV-N het vermelden waard. Nuyens vindt voor mannen onder de 50 jaar een hogere klachtenscore bij zwaardere werkomstandigheden (ploegendienst, meer dan 9 uur per dag werken, meer dan een kwartier reistijd) en, en dat is woor de uiteindelijke model-constructie van belang, een verband tussen de "dichtheid van het aanbod wan voorzieningen' en het gemiddeld aantal klachten, gecorrigeerd voor leeftijd, geslacht en ziektegeschiedenis. Niet voor verstedelijkingsgraad overigens. Als het inderdaad zo zou zijn dat het aambod van voorzieningen ook positief zou werken op het aantal gezondheidsklachten, dan is dat een belangrijk gegeven voor de constructie van ons model. In Nijhof's onderzoek worden relaties gevonden met werkomstandigheden (ook weer volgens opgave respondent) en met een aantal 'onbehagen' metende schalen (machteloosheid, anomie etc.) Nijhof $(282,283)$. De auteur stelt de validiteit wan zijn schalen (van de klachtenschalen en van de overige) echter niet ter discussie.

\section{Conclusie}

Als we ons beperken tot de wier basiswariabelen "leeftijd', 'geslacht", "status' en 'burgerlijke staat' dan is de relatie tussen klachtenscore en geslacht consistent (Cassee's bevinding uitgezonderd), het verband met leeftijd niet ondubbelzinnig, is het bij 'status" de vraag welke rol de variabele 'gezondheidstoestand' in het geheel speelt (iets wat uiteraard ook bij 'leeftijd' een rol moet spelen) en is niet veel aandacht besteed aan de relatie burgerlijke staat en klachten. Bovendien blijken klachtenscores samen te hangen met arbeidsomstandigheden, werkloosheid en andere maatschappelijke problematiek. In de meeste onderzoekingen is het effect van 'gezondheidstoestand' geen onderwerp van analyse geweest, in de meeste studies wordt een lijst met lichamelijke klachten of als indicator voor 'gezond- 
heidstoestand" opgevat, of als een maat voor emotionele of neurotische labiliteit of er wordt nar believen tussen deze interpretaties heen en weer gesprongen.

Het lijkt ons een eerste vereiste om 'slechte gezondheid' en 'emotionele labiliteit' analytisch en liefst ook empirisch van elkaar te scheiden.

\subsection{Constructie van een model ter verklaring van klachtenscores}

Uiteraard is het weer Mechanic die in zijn artikel 'the experience and reporting of common physical complaints' (Mechanic, 1980) ons vóór is met de constructie van een model waarin een lijst met lichamelijke k]achten de afhankelijke variabele vormt en 'slechte gezondheid' en 'neuroticisme' de twee belangrijkste onafhankelijke variabelen zijn. Mechanic's model komt erop neer dat bepaalde variabelen iemands neuroticisme-score verklaren en andere iemands gezondheidstoestand en dat deze beide factoren van invloed zijn op het aantal opgegeven lichamelijke klachten. ${ }^{33}$ (Mechanic, 1980, 152-153)

Wij zullen zijn model overnemen met een voor ons doel adequate set variabelen.

In ruwbouw ziet ons model er als volgt uit:

Figuur 5.1.: Schematische weergave van een model ter werklaring van lichamelijke klachten.

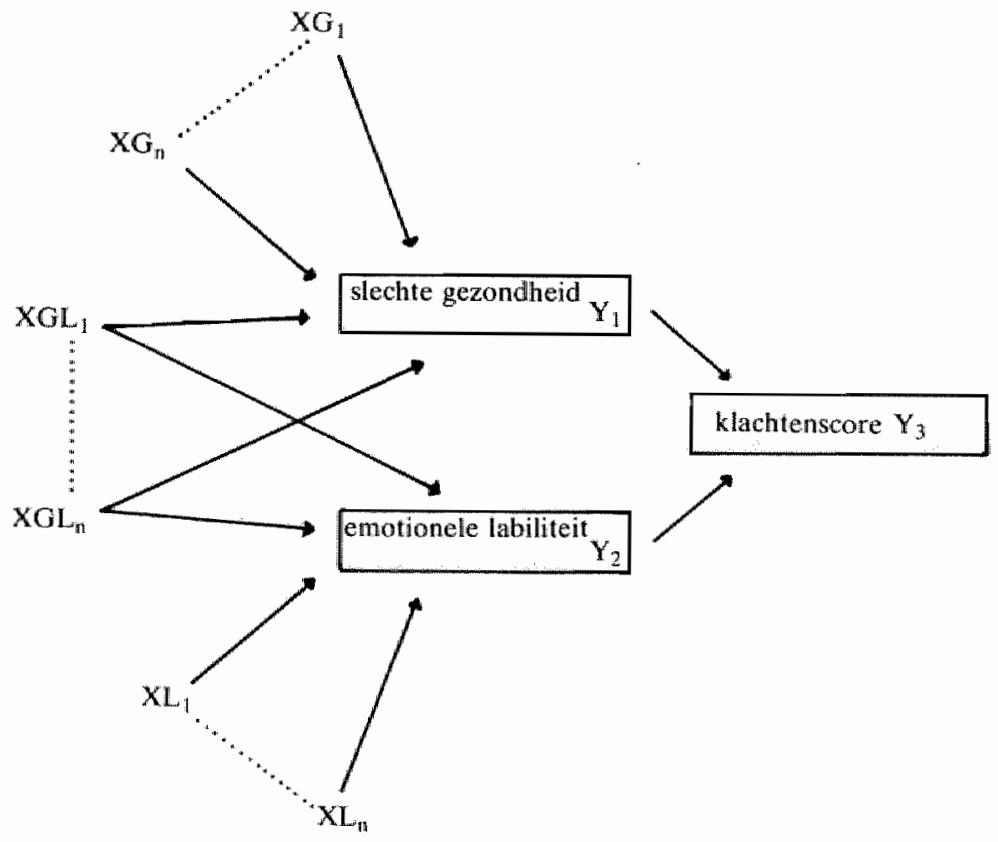


Een aantal niet verder verklaarde (gepredetermineerde in modeltermen) variabelen beinvloedt hetzij alleen gezondheidstoestand, hetzij alleen emotionele labiliteit, hetzij beide variabelen. Deze laatste beïnvloeden op hun beurt iemands score op een lijst wan fysieke klachten.

De belangrijkste opgave waarvoor we ons hier gesteld zien is het vaststellen (op grond van reeds verricht onderzoek) welke variabelen van invloed zijn op iemands gezondheidstoestand en iemands emotionele labiliteit. Aan beide onderdelen zullen we een paragraaf wijden, waarna we tenslotte een model ter toetsing zullen construeren.

Bij de constructie van ons model ter verklaring van klachtenscores hebben we ons (evenals bij de modelconstructie voor de verwolgfasen: doktersbezoek en verwijzingen) een rigoureuze beperking opgelegd.

We beperken ons namelijk tot die verklarende variabelen, die te beschouwen zijn als algemene biografische achtergrondkenmerken (leeftijd, geslacht, burgerlijke staat, status, werkomstandigheden, gezinssamenstelling) en die slechts de ruwe contouren aangeven van het menselijk gedrag.

Wij hebben hiervoor twee redenen. De eerste is, dat wij willen streven naar de constructie van een model voor de gezondheidszorg als geheel, op basis van beschikbare gegevens. In het algemeen heeft men slechts de beschikking over hetgeen meestal als "achtergrondkenmerken" wordt betiteld. Men kent de verdeling van de bevolking naar leeftijd, geslacht, burgerlijke staat, inkomen, verzekeringsvorm, enzovoorts, maar hoe opvattingen over ziekte, gezondheid en gezondheidszorg, gesteld dat deze van invloed zouden zijn, over de bevolking zijn gespreid, is zelden bekend.

Op dit punt wijkt onze studie, zoals we in de inleiding hebben gezegd, het sterkst af van de gebruikelijke studies naar medische consumptie.

Ook in de zogenaam de 'praktijkstudies' weet men zelden meer van de patiënten dan de huisarts op zijn kaart heeft aangetekend; in het algemeen slechts summiere demografische kenmerken.

Ten tweede willen wij niet in de vaak gemakte fout vervallen van nietszeggende samenhangen. Iemands klachten over zijn gezondheid hangen in het algemeen tamelijk hoog samen met de tevredenheid over zijn gezondheid. De tevredenheid over $z$ ijn gezondheid is weer onderdeel van iemands tevredenheid met het leven in zijn algemeenheid. Alle schalen die in deze sector worden gebruikt (en dal zijm er nogal wat) hangen met elkaar samen op basis van dit algemene gevoel van tevredenheid onbehagen of machteloosheid. Multicollineariteitsproblemen maken een analyse met een causale volgorde tussen leden van deze schalenfamilie tot een hachelijke onderneming. Daarom vindt men in dit werk zo min mogelijk correlaties tussen anomie, vervreemding, machteloosheid, satisfactie, enz. enz. en gezondheidsklachten. Alleen het gedeelte van de klachten dat te verklaren is uit de randwoorwaarden woor iemands gedrag is onderwerp van bespreking in de volgende paragrafen. 


\subsubsection{Gezondheidstoestand}

Gezondheidstoestand willen we operationaliseren op een manier die enerzijds niet of in ieder geval zo min mogelijk gecontamineerd is met een klachtenscore, maar anderzijds ook weer niet een tautologische relatie heeft met medische consumptie. Stel dat men gezondheidstoestand zou indiceren met het al dan niet opgenomen geweest zijn in een ziekenhuis in de periode voorafgaande aan de ondervraging, dan heeft men weliswaar een tamelijk goede kans dat de gezondheid van de ondervraagde niet optimaal was in de betreffende periode, maar is een verband tussen de op deze wijze geoperationalliseerde variabele en variabelen als contact met huisarts en specialist met de wijze van operationaliseren gegeven. Op analoge wijze is het indiceren van gezondheidstoestand met enkel en alleen de perceptie van iemands gezondheid al te zeer gecontamineerd met een klachtenscore.

We dienen dus te streven naar een maat die enerzijds zo min mogelijk subjectief is en anderzijds niet direct gecontamineerd is met consumptie.

Binnen de beperkingen wan het vragenlijstonderzoek hebben we gekozen voor de (in paragraaf 6.3. in detail beschreven) antwoorden op vragen naar het lijden aan in het algemeen als ernstig of chronisch beschouwde aandoeningen. 'Gezondheidstoestand' betekent in ons onderzoek 'chronisch slechte gezondheid'.

\section{Gezondheidsioestand beinvloedende factoren}

Dat gezondheidstoestand in belangrijke mate bepaald wordt door 'leefrijd' hoeft geen betoog. De enige vraag die we moeten beantwoorden is die naar de aard van het verband. Betreft het cen lineaire relatie of is de samenhang complexer. Ons zijn geen onderzoekingen bekend waar de relatie tussen gezondheidstoestand en leeftijd anders dan lineair is afgebeeld. Dit in tegenstelling tot het verband tussen leeftijd en medische consumptie, waar de verschillende modelconstructeurs (zie bijvoorbeeld Van der Gaag, 1978, Rutten, 1978) het bekende kromlijnige verband in een fraaie meertoppige curve hebben trachten te vangen. We houden het voor deze studie, gegeven het feit, dat onze leeftijdsverdeling pas bij 15 jaar begint, voorlopig op een lineair verband, mochten de resultaten tot een modificatie aanleiding geven, dan zullen we daar nog op ingaan.

\section{Geslach}

Als men levensverwachting en sterftekansen als geldige indicatoren wan gezondheidstoestand beschouwt (en dat zijn het in globale zin uiteraard ook-vergelijk de levenswerwachting van de inwoners van Noord Amerika met die van het Zuidelijk deel van dit continent) dan komen vrouwen er beter af dan mannen. Daar staat tegenover dat voor alle andere gezondheidsindicatoren (ziekenhuisopnamen, frequentie van ziekteverzuim, morbiditeitscijfers) vrouwen hoger scoren, ook als men rekening houdt met het gegeven dat er dankzij de hogere levenswerwachting, meer oudere vrouwen dan mannen zijn.

Verbrugge (1976) wijdt een beschouwing aan deze paradox aan de hand wan 
gegevens over de periode 1957-1972 gedestilleerd uit de Amerikanse Health Interview Surveys. Uit haar gegevens blijkt dat, op de morbiditeitscategorie 'ongevallen' na, vrouwen meer acute aandoeningen rapporteren en daarvoor vaker en langer in bed liggen (Verbrugge, 390-92), dat ze ook meer chronische aandoeningen rapporteren, maar op dat gebied wat minder gehinderd zijn in dagelijkse activiteiten (Verbrugge, 1976,396). Over de periode 1957-1972 wordt het verschil in de incidentie van chronische aandoeningen tussen mannen en vrouwen kleiner, hetgeen samenvalt met de afnemende levensverwachting voor mannen in dezelfde periode. Verbrugge stelt dat een deel van deze verschillen te wijten is a an de aard van het meetinstrument (vooral bij de 'acute condities' benadert het Health Interview Survey een algemene klachtenlijst en zouden vrouwen meer geneigd zijn te klagen-op-uitnodiging, bovendien wordt in de Health Interview Surveys aan de vrouw des huizes gevraagd te rapporteren over de afwezige (meestal mannelijke) gezinsleden, thetgeen onder-rapportage teweeg kan brengen), voor een deel aan verschillen in leefwijze en dagelijkse bezigheden tussen mannen en vrouwen (mannen roken en drinken meer en rijden meer auto, cf de hogere scores woor ongevallen) en voor een deel aan geslachtsbepaalde morbiditeit (vrouwen zouden een hormonale bescherming hebben tegen (voortijdige) doodsoorzaak nr. 1 - het hartinfarct) (zie ook Verbrugge, 1975).

$\mathrm{Zij}$ doet bovendien de interessante suggestie dat wellicht vrouwen een op de langere termijn gezondere reactie op verstoringen van hun lichaam hebben; bedrust nemen, kalm aan doen, huisarts raadplegen zijn wellicht zaken die in eerste instantie de aan ziekteverzuimcijfers, en geneeskundige behandeling gerelateerde kosten van de gezondheidszorg verhogen, maar op de lange duur minder slijtage aan het organisme veroorzaken.

Hoe het ook zij - we kunnen verwachten dat, hoewel we hebben geprobeerd de contaminatie tussen aandoeningen en klaaggeneigdheid zo gering mogelijk te maken, ook bij onze variabele 'chronisch ziek' vrouwen hoger zullen scoren dan mannen.

\section{Sociale Status}

Op grond van buitenlandse differentiële sterftestatistieken (Van Poppel, 1978, geeft hiervan een helder overzicht ${ }^{34}$; helaas ontbreken in Nederland dergelijke statistieken nog) blijkt een aanzienlijke sociale ongelijkheid voor de dood.

Hoe lager men op de maatschappelijke ladder staat, hoe slechter de levensverwachtingen zijn. De bijdragen op het in 1980 gehouden jubileumcongres van de Algemene Nederlandse Vereniging van Sociaal Geneeskundigen (zie de bijdragen van Morris, Zielhuis, Merens-Riedstra, Van Sonsbeek en Bonte, allen 1980) geven evidentie uit verschillende bron.

Newacheck e.a. (1980) laten op grond van gegevens uit het Amerikaans National Health Interview Survey van 1977 zien, dat de grote 'overall" verschillen in gegevens over ziekte en consumptie tussen gezinnen met een inkomen onder of boven de 
"armoededrempel" (6000 dollar) vooral gelden voor volwassenen van 45-64 jaar. Onder en boven deze leeftijdscategorie zijn de versehillen geringer. Zij maken a annemelijk dat wooral de bij de laagbetaalde groep op jongere leeftijd optredende, chronische aandoeningen verantwoordelijk zijn voor de grote verschillen in de leeftijdscategorie 45-64 jaar.

Hoe lager men op de maatschappelijke ladder staat hoe eerder men chronisch ziek zal zijn. Over de gehele linie zal men meer chronisch zieken vinden onder mensen met een lagere dan met een hogere status. ${ }^{35}$

\section{Burgerligke Staat}

Er is wel literatuur bekend waaruit men zou kunnen afleiden dat "alleen leven' ongezonder is dan samenleven met anderen. Zo bezien Kobrin en Hendershot (1977) sterftecijfers naar burgerlijke staat én positie in het gezin (niet getrouwd zijn betekent overigens in het geheel niet dat men ook alleen leeft) en komen tot de conclusie dat een gezinsverband in één of andere vorm (of dat nu compleet is of niet) een zekere bescherming biedt tegen de gevaren des levens; zij sluiten met hun conclusies a an bij de bewindingen van Gove (1974), die laat zien dat niet getrouwden hogere sterftecijfers hebben in diagnosecategorieën die te maken hebben met icmands leefgewoonten (alcohol, roken, autorijden) en geestelijke gezondheid (zelfmoord). De verschillen in de categorieën zijn echter voor mamen sterker dan voor vrouwen.

Gove stelt dat het huwellijk voor mannen meer voordelen en bescherming biedt dan voor vrouwen; ongehuwde of niet meer gehuwde mannen zijn er slechter aan toe dan vrouwen in vergelijkbare omstandigheden; gehuwde vrouwen daarentegen weer slechter dan hun echtgenoten (als men tenminste moet afgaan op sterftecijfers). Gove wijt hogere sterftecijfers van ongehuwden of niet meer gehuwden vooral aan zogenaamde 'riskante gewoonten', en het ontbreken van dagelijkse sociale controle. In zijn cijfers kan hij (in tegenstelling tot in zijn betoog, waarin hij in navolging van Durkheim wijst op de sociale bescherming die het hebben van kinderen biedt) geen onderscheid maken tussen burgerlijke staat en de samenstelling van iemands directe sociale orngeving. Hij meet niet welke gehuwd geweest zijnde personen ook geheel alleen leven.

Naast deze sterftecijfers zijn verder weinig gegevens over de samenhang tussen burgerlijke staat en gezondheid bekend. Butler en Morgan (1977) wijzen op een hogere frequentie van ziekenhuisopnamen onder niet (meer) gehuwde personen, maar merken op dat de keuze tussen intramurale en ambulante zorg ook zal worden ingegeven door het al dan niet ontbreken van woldoende zorg in de directe sociale omgeving.

We moeten hier concluderen dat het niet echt duidelijk is of niet (meer) gehuwden nu 'ongezonder' zijn, alle andere factoren meegerekend.

Gaat men uit van klachtenscores dan is dubieus in welke mate nu geestelijke en lichamelijke factoren een rol spelen; gaat men uit wan gegevens over hospitalisatie, 
dan is het moeilijk wit te maken in welke mate het ontbreken van mogelijkheden tot thuisverpleging de cijfers beïnwloedt en tenslotte zijn sterftecijfers niet de meest ondubbelzinnige indicatoren voor gezondheidstoestand.

We zullen voor ons model geen relatie formuleren; we houden het or op dat "chronisch slechte gezondheid" vooral een functie is van leeftijd en in mindere mate van geslacht (in de zin dat we verwachten dat wrouwen een slechtere gezondheid hebben dan mannen) en sociale status (mensen uit de laagste statuscategorie hebben de slechtste gezondheid).

\subsubsection{Emotionele labiliteit}

We spreken liever over 'emotionele labiliteit' dan over 'klaaggeneigdheid', niet zozeer omdat we nu het uiten van klachten (op uitnodiging) willen toeschrijven aan kenmerken van de persoon van degene die de klachten uit, maar omdat 'klaaggeneigdheid' niet zo'n fraaie term is. ${ }^{3.6}$ Het is, methodologiseh gesproken, een dispositie-term en zou eigenlijk onafhankelijk van het feitelijk klagen gemeten moeten worden. Er zijn wel pogingen in die richting ondernomen. Zo heeft Dirken met behulp van vragen als 'Hebt $\mathbf{U}$ weleens last van een pijnlijk gevoelige schedel' geprobeerd het 'klagen' te isoleren van het 'last hebben van symptomen'. Deze en dergelijke vragen werden echter massaal met 'neen' beantwoord. 'Klagen' zonder 'last hebben van' komt niet voor. Ormel (1980b, 172-73 en 272-74) laat de inverviewer de respondenten beoordelen op de dimensie: "klagen-loochenen" en 'openhartig-gesloten'. Hij vindt een correlatie van -.23 tussen neuroticisme en de eerstgenoemde dimensie. Beide bevindingen wijzen in de richting van een zekere contaminatie tussen 'klaag-geneigdheid' en 'neuroticisme'. We zullen daarom met opzet nu en dan de termen 'emotionele labiliteit', 'klaaggeneigdheid', "malaise" en 'spanningsklachten' door elkaar gebruiken. Onzes inziens is de term 'emotionele labiliteit' het meest neutraal (al zou men ook deze term een dispositie-term kunnen noemen). Met de bovengenoemde termen benoemen we iemands score op een lijst met niet-lichamelijke klachten.

In het Leef Situatie Onderzoek 1977 is een verkorte versie opgenomen van de niet-somatische sublijst van de Amsterdamse Biografische Vragenlijst (ABV-N): deze lijst is niet gecontamineerd met icmands lichamelijke gestelcheid en meet een zekere mate van onwelbevinden waarvan we modelmatig onderstellen, dat dit de k laagcomponent van de lichamelijke klachtenscore representeert. Of, in fatsoenlijk Nederlands: het stukje wan de score op de lijst met lichamelijke klachten dat toe te schrijven is a an een algemeen gevoel van malaise. We zullen het eerst bezien hoe de drie variabelen (leeftijd, status en geslacht) watrvoor we een verband met gezondheidstoestand werwachten vermoedelijk verband houden met het uiten wan bowengenoemde klachten. Verwolgens zullen we enkele overwegingen formuleren met betrekking tot andere variabelen. 
Leefrijal

In tegenstelling tot de biologisch bepaalde relatie tussen leeftijd en gezondheidstoestand achten wij het verband tussen leeftijd en het uiten van klachten eerder een generatiegebonden verschijnsel. De oudere generatie is minder geneigd zijn klachten naar buiten te brengen dan de jongere en heeft in het algemeen (zie Philipsen, 1977) een wat sterkere neiging tot dissimulatie van klachten en ziekteverschijnselen.

Als deze verwachting correct is dan geeft dit meteen een verklaring voor soms moeilijk te interpreteren relaties tussen leeftijd en klachtenscores, die in verschillende onderzokkingen gevonden zijn (zie paragraaf 5.1.). Het ontbreken wan een werband kan goed verklaard worden door de tegengestelde werking van de biologische component van leeftijd en de cultureel bepaalde generatiecomponent.

\section{Geslacht}

Vrouwen klagen meer dan mannen. In onze cultuur is het vrouwen meer toegestaan dan mannen om hun gevoelens en emoties te tonen en aandacht te besteden aan het functioneren van hun lichaam.

Vele studies zijn aan dit verschijnsel gewijd, (zie bijvoorbeeld de studies van en discussie tussen Dohrenwend en Dohrenwend $(1976,1977)$ enerzijds en Gove en Tudor (1977) anderzijds), alle auteurs zijn het erover eens dat vrouwen hogere klachtenscores hebben.

Meestal wordt de hogere score van vrouwen in verband gebracht met hun burgerlijke staat, hun rol in het gezin en het al dan niet volledig werkzaam zijn in de huishouding. Hierover is tussen Gove (en verschillende mede-auteurs - Zie Gove en Tudor (1973), Gove en Geerken (1977), Hughes en Gove (1981)) en anderen (Mechanic (1978), Fox (1980)) een interessante discussie ontstaan, die wij zullen weergeven bij de behandeling van de invloed van 'burgerlijke staat" op "emotionele labiliteit'.

In tegenstelling tot de verwachte invloed van leeftijd (hoe ouder, hoe slechter de gezondtheid, maar hoe jonger hoe meer geneigd tot klagen) zal de verwachte invloed van 'gesiacht' op 'emotionele labiliteit' in dezelfde richting zijn als het verband tussen "geslacht' en 'gezondheid". ${ }^{3.7}$

Aangezien in de meeste studies de geestellijke en lichamelijke (d.w.z. aan slechte gezondheid toe te schrijven) component van de klachten niet worden onderscheiden, vrezen wij dat dit dan wel geleid heeft tot het overschatten van het aantal psychoneurotische stoornissen bij vrouwen dan wel tot een onderschatting van de gezondheidstoestand wan (met name oudere) vrouwen. Voor ons model doet dat er niet zoveel toe; we verwachten zowell een sterke relatie met "emotionele labiliteit" als een verband met gezondheidstoestand; tezamen zorgt dit een door het gecombineerd effect voor een hoge score op de lijst met lichamelijke klachten. 


\section{Sratus}

Dezellfde moeilijkheid (het onderscheiden van de gerondheids- en de klaagcomponent) doet zich voor bij het vaststellen van de invloed van de factor 'status'; een

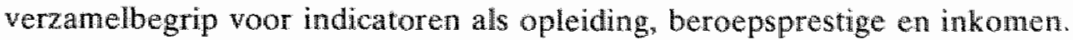

In paragraaf 5.1. stelden we al dat in Nijhof's studie het verband tussen de meeste status-indicatoren en de door Nijhof gebruikte batterij met psychiatrische tests verdween als men de gezondheidstoestand van de respondent constant hield. (Alleen het verband met inkomen hield nu en dan stand).

Daar kan men tegen inbrengen dat in Nijhof's onderzoek 'gezondheid' wel zeer subjectief was gemeten (alleen het globale eigen oordeel van de respondent). hetgeen een contaminatie tussen de maten van onwelbevinden en 'gezondheid" tengevolge kan hebben gehad, waardoor het verdwijnen wan het verband niet zo veel zegt.

De meeste onderzoekers (zie onze bespreking van de literaturur over klachtenscores) vinden dat mensen meer klagen naarmate hun sociaal economische status lager is. Dit geldt zowel voor lichamelijke klachten als voor psychische spanningsklachten (zie bijvoorbeeld bij Pommer en Van Praag het verband tussen gezinsinkomen en ABV-N).

Gevolg van dit alles is een hogere score op een lijst met lichamelijke klachten voor personen onder aan de maatschappelijke ladder. Toch zouden wij op voorhand niet durven zeggen of nu de slechte gezondheid danwel de 'klaagcomponent' de sterkste invioed uitoefent en of het effect van deze laatste component niet verdwijnt als de invloed van gezondheidstoestand is verdisconteerd of dat de coëfficiënt (net als bij leeftijd) zelfs van teken verandert. Nuyens e.a. troffen immers aan dat (vooral vrouwen) uit de hogere sociaal-economische strata meer klachten rapporteerden, gegeven (onder meer) hun gezondheidstoestand.

\section{Burgerlijke Staat}

Meer overeenstemming dan over het antwoord op de vraag of burgerlijke staat unvloed heeft op iemands lichamelijke gezondheid is er over het bestaan van een relatie tussen burgerlijke staat en geestelijke gezondheid. Alleen over de aard van het verband zijn de geleerden het niet eens. De meeste auteurs vinden vootal bij gescheiden vrouwen en weduwen hoge scores op lijsten met lichamelijke dan wel psychische symptomen. (Zie bijw. Dohrenwend en Dohrenwend, 1976, Verbrugge, 1976). Walter Gove houdt echter staande dat juist getrouwde vrouwen de hoogste scores hebben en dat zelfs de in-het-algemeen-hogere-scores van vrouwen terug te voeren zijn op hogere scores van deze groep. (Gove, 1972 , 1974, Gove en Tudor. 1973,1977 ). In een kritische bespreking van het werk van Gove stelt Fox dat Gove slordig omspringt met z'n bewijsvoering. Hij baseert zich op een samenstel van maten, waarvan de gegevens over behandelde geestelijke gezondheid de belangrijkste plaats innemen en dat waar in feite (ook volgens Gove zelf) onbohandelde symptomen wan onwelbevinden beter geschikt zijn. ${ }^{36}$ 
Als Fox aan de hand van de door Gove (en Tudor) zelf opgestelde criteria een (her)analyse onderneemt van verschillende landelijke survey's, dan windt hij dat vrouwen in alle wormen van burgerlijke staat hoger scoren en in het algemeen hogere scores woor niet meer gehuwde personen. Van Gove's stelling, dat de scores van getrouwde vrouwen de algeheel hogere scores van vrouwen zouden verklaren, blijft niets over. Fox" conclusie is dat het blijkbaar van de definitie van "mental illness' afhangt (behandelde versus onbehandelde) of Gove's stelling wordt bewezen of weerlegd. Op zichzelf is dat een interessante constatering; voor ons doel (het verklaren wan klachtenscores) zijn Fox" bevindingen het meest van belang. We houden het erop dat het getrouwd geweest zijn, het verlies van een partner door scheiding of dood, voor mannen èn vrouwen een verhoogde klachtenscore oplevert, ook als men (bij weduwen en weduwnaren bijvoorbeeld) rekening houdt met hun door leeftijd bepaalde slechtere gezondheid en hun generatiegebonden geringere neiging tot klagen. We verwachten voor gescheidenen (voor zover ze althans van een jongere generatie zijn) nog hogere scores te vinden dan voor verweduwden, nadat we de 'gezondheidscomponent' in de klachtenscores hebben uitgeschakeld. Vrouwen-met-een-partner zouden niet zozeer meer klagen maar gegeven de hoogte van de klachtenscore vaker behandeld worden bijvoorbeeld door een huisarts of hulpverleners in de geestelijke gezondheidszorg.

\section{Werkloosheid; WAO}

Geen werk meer hebben door arbeidsongeschiktheid of ontslag is evenals het niet meer hebben van een partner te karakteriseren als een min of meer stabiele suboptimale situatie, zeker (wat werkloosheid betreft) in een neergaande conjunctur. De kansen op de arbeidsmarkt voor oudere en jeugdige werklozen en de kansen op de huwelijksmarkt voor bijvoorbeeld oudere vrouwen zijn ronduit sllecht. $\mathrm{Er}$ is weinig aan de situatie te veranderen; men wordt er voortdurend (door bijvoorbeeld sollicitatieplicht bij werkloosheid) aan herinnerd.

Een dergelijke stabiliteit zou heel goed kunnen verklaren waarom klachtenscores zo weinig in de tijd veranderen. In Ormel's proefschrift (1980b, 166-67) ziet men dat de klachtenscores bij herhaling van de meting na zes jaar weinig zijn veranderd. Bowendien blijken acuut optredende problemen de scores nauwelijks, of in ieder geval niet consistent, te beïnvloeden. Ormel vindt ook voor werklozen en arbeidsongeschikten hoge scores evenals Adriaanse e.a. in thet verslag van het onderzoek in het kader van de actie Nederland-Oké (Adriaanse, Drop. Halfers en Philipsen, 1981). In Engeland laten Marks, Goldberg en Hillier (1979) zien dat gescheiden wonende nog gehuwde personen en gescheiden personen hogere scores vertonen op de reeds genoemde General Health Questionnaire. Zij vinden dezelfde hogere scores voor werklozen, met uitschieters voor vrouwen, inclusief huisvrouwen, die zichzelf als werkloos beschrijven. (Marks, e.a., 342-43). Bij arbeidsongeschiktheid speelt de 'gezondheidscomponent' uiteraard een belangrijke rol; bij werkloosheid niet of minder. Wij verwachten niet dat werklozen een slechtere gezondheid zullen 
hebben dan, op grond van hun leeftid, geslacht en status kan worden verwat.

\section{Geen goede gezondheid meer}

Een derde suboptimale situatie is te omschrijwen op het gebied van ziekte en gezondheid. Een slecht lichamelijk functioneren, slecht ter been zijn, niet goed kunnen meekomen, telt des te sterker, menen wij, als de meeste van iemands generatiegenoten nog in goede gezondheid verkeren; bijvoorbeeld bij mensen jonger dan 65 jaar.

Bovenstaande onderstelling compliceert het model aanzienlijk; het geeft een verband aan tussen twee gescheiden componenten van ons model en vergt een extra toetsing van de loop van het causale verband.

Voor het model zou beter zijn als 'gezondheid' en 'emotionele labiliteit' niet zouden samenhangen. Wij hebben nadrukkelijk geprobeerd om de begrippen van contaminatie te zuiveren (het meest voorkomende euvel in dit type onderzoek); wij kunnen uiteraard niet voorkomen dat de beide componenten van het model ook in feite samenhangen.

We verwachten dat personen met een slechte gezondheid ook gemiddeld een wat hogere score op de lijst met niet-lichamelijke klachten zullen hebben, deels doordat niet alle contaminatie kan worden verwijderd (per slot van rekening gaat het om een samenhang tussen zaken die in laatste instantie gemeen hebben dat ze aan mensen worden gevráagd) en deels doordat het verlies van bepaalde functies het leven inderdaad moeilijker en zwaarder maakt.

\section{Normatieve integratie}

Het aantal mogelijke theorieèn en modellen ter verklaring van fluctuaties in scores op lijsten met klachten van lichamelijke en geestelijke aard is legio, zoals we al hier en daar hebben laten zien. Klachtenscores spelen een rol in de theorieën rond het ontstaan van psychische stoornissen, in de theorieën rond het begrip 'stress", in de persoonlijkheidspsychologie, in de aetiologie van psychosomatische afwijkingen en stoornissen, in de empirische operationele benadering van het begrip "vervreemding' (Sierksma, 1971), in de 'social biology' en in de literatuur rond het begrip 'afwijkend gedrag'.

Het gaat ons cenvoudige denkraam verre te boven een integratie van ook maar enkele van deze benaderingen te geven en wij zouden dan ook niet het woord 'normatieve integratie' boven dleze subparagraaf hebben geplaatst als onze aandacht niet was getroffen door enkele resultaten uit de rapportages die medewerkers van het Sociaal en Cultureel Planbureau en het Centraal Bureau voor de Statistiek over het Leef Situatie Onderzoek 1977 hebben verzorgd. Reeds vermeld is het verband dat Pommer en Van Praag vonden tussen 'sociale isolatie' en de ABV-N (Pommer en Van Praag, 1.978, correlatiematrix); Jol (1980a) vond in haar beschrijving van 'balende huiswrouwen' (een voorbeeld overigens, wan een analyse met wel erg heterogene variabelen) dat onkerkelijke vrouwen een negatiever oordeel over 
heit huishouden hadden dan kerkelijke en met name kerkse vrouwen.

Deze resultaten zijn te interpreteren als men bekend is met de dissertatie van Drop (1979) en van de daarin met behulp van per gemeente verzamelde gegevens getoetste hypothesen over de relaties tussen arbeidsverdeling, sociale beheersing, normatieve integratie en een index van intropunitieve, legitieme gedragingen (vluchtgedrag) en de op anderen gerichte, meest illegitieme gedragsvormen (index aggressief gedrag);

Drop $(1979,35-39)$ beschouwt opname in een psychiatrische inrichting met een diagnose in de categorie neurosen evenals echtscheiding en niet-stemmen bij verkiezingen als een worm van wiuchtgedrag, een op zichzelf gerichte ontwijkende reactie van het individu. ${ }^{39}$

De belangrijkste factor ter verklaring van de gedragsindices (zie Drop, 1979, 152-176, voor een overzicht van haar bevindingen) is de index 'normatieve integratie' (bestaande uit 3 indicatoren: \% kerkelijken, \% autochtonen, en een coëfficiënt voor de diversiteit van de door de inwoners uitgeoefende beroepen). Deze index normatieve integratie hangt negatief met vluchtgedrag -- hoe minder geïntegreerd, hoe meer vluchtgedrag - en positief met agressief gedrag samen. Naast normatieve integratie zijn er in deze op Durkheim stoelende theorie over het ontstaan van afwijkend gedrag nog twee belangrijke factoren.

Ten eerste de omvang van de al dan niet geintegreerde groep. Hoe groter de groep is, des te moeilijker valt het om het gedrag van de groepsleden te beheersen. Vluchtgedrag met name ontstaat in situaties waarin gedragsalternatieven mogelijk zijn. In het model van Drop wordt bovendien, in de Durkheimiaanse traditie, gesteld dat een sterke mate van arbeidsdeling de normatieve integratie in negatieve zin beinvloedt.

Als we ervan uitgaan dat neurotische of emotionele labiliteit een vorm van vluchtgedrag is, dan kunnen we, blijkens het voorgaande, een zinvol verband leggen tussen zaken als inwonertal van de woongemeenschap, indicatoren alls kerkbezoek, kerklidmaatschap, autochtonie (helaas, helaas niet als variabele in het LSO 77 (wel in dat van '74) opgenomen) en deze meestal legitieme (dat wil zeggen niet onder het strafrecht vallende) afwijkende gedragingen, dat wil zeggen vluchtgedrag in het algemeen en neurotische labiliteit in het bijzonder. De in het Leef Situatie Onderzoek opgenomen variabelen: 'lidmaatschap kerkgenootschap', 'kerkbezoek' en "sociale integratie' alsmede de ornvang van de woongemeente kunnen op grond van deze overwegingen als verklaring voor de fluctuaties in klachtenscore (althans voor het niet door slechte gezondheid verklaarde deely in het model worden opgenomen. 


\subsection{Samenvatting en conclusie}

Nadat wij in hoofdstuk 3 hadden geconstateerd dat ieder die de vraag 'waarom gaata mensen naar de dokter' met behulp wan ingewikkeld en duur onderzoek heeft willen beantwoorden, niet veel verder is gekomen dan "omdat mensen klachten hebben over hun gezondheid', hebben we ons in hoofdstuk 4 de vraag gesteld: 'Wat zijn dan lichamelijke klachten?'

Dat bleek dus (gelukkig voor de sociale wetenschappen) tamelijk ingewikkeld in elkaar te zitten; enerzijds hebben lichamelijke klachten betrekking op iemands gezondheidstoestand, anderzijds heeft 'klagen-op-uitnodiging' ook te maken met iemands geestelijke gezondheid en wel met iemands emotionele of neurotische labiliteit.

In hoofdstuk 5 zijn we op zoek gegaan naar onderzoekingen die het uiten van lichamelijke klachten in verband hebben gebracht met persoonlijke en maatschappelijke omstandigheden. In de door ons bestudeerde en beschreven literatuur spelen "gezondheidstoestand" en "klaaggeneigdheid' tamelijk onsystematisch door elkaar. De meeste auteurs maken geen onderscheid tussen beide componenten, hetgeen hun resultaten doorgaans moeilijk interpreteerbaar maakt, zeker als een bepaalde variabele 'gezondheidstoestand' en 'klaaggeneigclheid' tegengesteld beinvloedt. Zo'n gegeven is "leeftijd". Uiteraard wordt de gezondheid slechter bij het ouder worden, maar de oudere generatie is wat minder geneigd om in te gaan op een uitnodiging tot het uiten van klachten. Haalt men deze twee componenten niet uit elkaar dan hangt het van toevalsfactoren af welke relatie men tussen 'leeftijd' en 'Jichamelijke klachten' vindt.

Na het literatuuroverzicht zijn we overgegaan tot het formuleren van verwachtingen over hetgeen we in ons onderzoek zullen aantreffen. Het ligt, gegeven het voorgaande betoog, voor de hand dat wij onze verwachtingen apart hebben geformuleerd voor de twee componenten van ons model: slechte gezondheid en emotionele labiliteit.

Heel kort samengevat zijn onze verwachtingen wat betreft 'slechte gezondheid' als volgt:

We verwachten:

1. een sterk verband met leeftijd. Hoe ouder men is, hoe slechter de gezondheid

2. een verband met geslacht (vrouwen hebben een slechtere gezondheid dan mannen)

3. cen verband met sociaal economische status (hoe hoger op de maatschappelijke ladder, hoe beter de gezondheid)

4. geen verband met burgerlijke staat (of althans - we weten niet wat we moeten verwachten).

Wat betreft 'emotionele labiliteit' verwachten we:

1. een negatief verband met leeftijd 
2. een zelfde verband met geslacht als woor "slechte gezondheid"

3. waarschijnlijk een negatief verband met social economische status; al weten we niet zeker of het verband, net als bij leeftijd, niet wan teken verandert, als met gezondheidstoestand is rekening gehouden

4. een verband met burgerlijke staat - in die zin dat we verwachten dat gescheiden personen, weduwen of weduwnaars hogere klachtenscores zullen hebben dan gehuwde of altijd ongehuwd geweest zijnde personen

5. dat werkelozen en arbeidsongeschikten hoger zullen scoren; de laatste groep ook op 'slechte gezondheid"

6. personen met een chromisch slechte gezondheid ook hogere scores op de factor 'emotionele labiliteit' zullen hebben

7. lagere klachtenscores voor (normatief) geïntegreerde personen; kerkbezaek en integratie in de directe woonomgeving zullen met lagere scores op een lijst met niet-lichamelijke klachten samenhangen

8. in grotere gemeenten de mensen meer geneigd zijn tot het uiten van klachten dan in kleinere.

De onder 1-3 genoemde relaties hebben betrekking op iemands globale positie in de maatschappij; de onder 4-6 geformuleerde verwachtingen hebben betrekking op wat we hebben aangeduid als "suboptimale" situaties (tamelijk onwrikbare, ongunstige omstandigheden) en de onder 7 en 8 genoemde verwachtingen slaan op iemands (normatieve) integratie, de mate waarin hij of zij is opgenomen in een normatief systeem en in de directe sociale omgeving; het aantal inwoners van de woongemeente geeft de mogelijkheden aan tot 'sociale beheersing'.

Deze verwachtingen zullen we toetsen met behulp van gegevens uit het Leef Situatie Onderzoek 1977, van welke toetsing we de resultaten in het volgende hoofdstuk presenteren. 


\section{Onderzoeksresultaten I; het verklaren van iemands score op een lijst met lichamelijke klachten}

\subsection{Inleiding}

Voor de toetsing van het in de vorige paragrafen omschreven model hebben we gebruik gemaakt van de door het Centraal Bureau voor de Statistiek verzameld en ons welwillend ter beschikking gesteld enquêtemateriaal, namelijk het bestand van het in 1977 gehouden Leef Situatie Onderzoek. ${ }^{40}$

Over deze nationale persoons-enquête is ruimschoots gepubliceerd (zie voor een algemene beschrijving de volgende publicaties: CBS, 1978, Sociaal Cultureel Rapport, 1978, en sommige deelpublicaties in het Sociaal Cultureel Kwartaalbericht, Jol, $1980 \mathrm{a}-\mathrm{c}$ ). Recentelijk publiceerden Van Vliet en Van de Ven (1982) een analyse van de gegevens op het gebied van medische consumptie (bezoek aan huisarts en specialist, gebruik van medicijnen).

De opzet van thet LSO komt er in het kort samengevat op neer dat een omvangrijke (in het geval van LSO' 77 telt men 4157 ingevulde vragenlijsten op een totaal van 5919 benaderde personen van 15 jaar en ouder) steekproef van Nederlanders uitvoerig wordt ondervraagd over wonen, werken, huishouden, gezondheid en welzijn in de ruimste zin van het woord. ${ }^{41}$ Voor ons doel is het gedeelte uit de wragenlijst dat betrekking heeft op de gezondheid der respondenten het meest wan belang. In dit gedeelte bevinden zich de variabelen die voor de operationalisatic van ons modell relevant zijn.

Het materiaal is, in aanmerking genomen dat het niet met onze oogmerken is verzamell, redelijk bruikbaar voor ons doel, zij het dat we hier en daar enige kunstgrepen hebben moeten toepassen om het materiaal woor analyse geschikt te maken. Aangezien de resultaten in sociall wetenschappelijk onderzoek in de gezondheidszorg dik wijls eerder tot toevalligheden in de samenstelling van het onder zoeksmateriaal dan tot verschillen in theoretische opvattingen van de onderzoekers 
terug te vocren zijn, zullen we (net excuus aan de minder in technische details geinteresseerde lezer) onze bewerking uitvoerig verantwoorden. Dit doen we wat betreft het probleem der ontbrekende waarden in paragraaf 6.3. In paragraaf 6.4 word het model gespecificeerd en tenslotte worden in paragraaf 6.5 de resultaten gepresenteerd. Het hoofdstuk wordt afgesloten met een samenvatting (paragraaf 6.6.), die summier wordt gehouden omdat in hoofdstuk 7 eem samenvatting van het gehele cerste deel volgt.

\subsection{Kunstgrepen. Het probleem der ontbrekende waarden.}

Werken met door anderen verzameld onderzoeksmateriall heeft woor- en nadelen. Voordeel is dat moeite en vooral kosten wan materiaalverzameling worden bespaard en dat mensen niet zonder grond met onrijpe vragen en probleemstellingen worden lastig gevallen. Nadeel is, dat men zelfs bij een breed opgezet onderzoek als het LSO 77 afhankelijk is wan elders genomen beslissingem.

Bovendien kan de onderzoeker niet 'terug' naar de vragenlijsten als hij een vermoedelijk onjuiste codering tegenkomt. In de hast waarmee het Leef Situatie Onderzoek is werwerkt (evenals het onderzoek wan 1974 dient het als basis voor het én jaar later verschijnende door het Sociaal Cultureel Planbureau om de 2 jaren vervaardigde Sociaal Cultureel Rapport) is het materiaal niet volledig gezuiverd van onwaarschijnlijke en onjuiste codes. ${ }^{42}$

Bovendien hebben miet alle respondenten op alle vragen antwoord gegeven; de rubriek "geen antwoord" of 'weet niet' bevat altijd enkele en soms (zoals bij de vraag naar het gezinsinkomen) een aanzienlijke hoeveelheid personen. Tenslotte zijn respondenten soms bewust door de onderzoekers van het CBS op een bepaalde wijze gecategoriseerd (zo ontbreekt bijvoorbeeld de variabele 'sociale status' bij geen beroepsarbeid verrichtende, verweduwde of gescheiden vrouwen; deze zijn ingedeeld onder de categorie 'werkzaam in eigen huishouding'). Deze ontbrekende waarden zijn als volgt "behandeld:

In het algemeen hebben we alle niet correcte codes bij de 'ontbrekende waarden' ondergebracht; we konden immers niet terug naar het enquêtemateriaal. Soms echter waren ingewikkelde kunstgrepen nodig. Deze zullen we per variabele beschrijuen.

Aangezien voor de in ons model gebruikte variabelen geldt dat zij elk voor zich een geringe hoeveelheid ontbrekende waarden tellen maar dat in combinatie het aantal bruikbare vragenlijsten zou afnemen van 4157 naar minder dan 3500 , hebben wij in onze regressie-analyse de ontbrekende waarden door het groepsgemiddelde vervangen, ${ }^{43}$ Onze analyses thebben dus als regel betrekking op alle 4157 respondenten. 


\subsection{Operationalisering van de variabelen}

\subsubsection{De onafhankelijke variabelen in het model}

\section{Biografische variabelen}

Operationalisering van 'leeftijd' en 'geslacht" levert geen probleem. Van alle respondenten is het geboortejaar bekend en is genoteerd of men 'man' of 'vrouw' is. 'Status' is de enige variabele in deze sector waarvan de operationalisering niet direct uit het materiaal is af te leiden.

Welswaar heeft de interviewer een ruwe schatting van de status gemaakt (een in kringen van marktonderzoekers niet ongebruikelijke procedure); dit gegeven is evenals de andere door de interviewer ingevulde opmerkingen over het vraagesprek, niet op de magneetband toegevoegd.

Wel heeft het CBS op grond van beroep, opleiding en inkomen (gezinsinkomen) een variabele 'sociale groep' geconstrueerd die voor de 4157 respondenten de volgende verdeling laat zien voor de totale groep. Bij niet-kostwinners is het beroep van de partner genomen; bij niet werkenden het vroegere beroep, bij thuiswonende scholieren en studenten het beroep van de vader.

Tabel 6.1.: Frequentieverdeling van de variabele 'sociale groep' LSO 77.

n

1. zelfstandigen in vrij beroep

2. zelfstandigen in landbouw of visserij

3. overige zelfstandigen

4. directeuren NV

5. employees hoog

6. employees midden

7. employees laag.

8. employees niveau onbekend

9. arbeiders

10. sociale groep onbekend

1. 1. dienstplichtige militairen

12. scholier/student (niet thuiswonend)

13. werkzaam in eigen huishouding
60

283

51

244

359

331

629

1529

213

2

54

183

$\%$ uiteindelijke codering

totarl

4157

1.4 hoog

5.3 midden, neutraal

6.8 midden, neutraal

1.2 hoog

5.9 hoog

8.6 hoog

8.0 midden, neutraal

15.1 midden, neutraal

$36.8 \quad$ laxg

5.1 nitet in te dalen

.0 nict in te delen

1.3 niet in te delen

4.4 hushotding

$100 \%$

In deze abel valt al iets van een statusrangorde te herkennen; de eerste 9 categorieên zijn door ons verder gereduceerd. Uitoefenaren van vrije beroepen (cat. l), 
directeuren NV (4) en hoge en middelbare employees ( 5 en 6) zijn samengevat als "hoog".

De groepen 'zelfstandigen in landbouw en visserij' (2). overige zelfstandigen (3) en employees niveau onbekend (8) en lage employees ( 7 ) zijn in een neutrale categorie terecht gekomen (noch hoog, noch laag). Bij de indeling is wooral geprobeerd de hoge en lage categorie goed van elkatr te onderscheiden; de middengroep is heterogeen; deels omdat zelfstandigen, boeren en vissers buiten de hoog/laag dimensie vallen en deels omdat van een aantal respondenten (categorie 8 , employees niveru onbekend, bijwoorbeeld) nadere gegevens ontbraken.

De "white-collar'/"blue collar" - hoofd/handarbeid-dimensie is de grondslag geweest van onze classificatie, waarmee we een niet ongebruikelijke indeling in de sociale wetenschappen volgen.

Desalniettemin resteren nog enkele categorieên. Er is een groep 'onbekend'; er zijn enkele scholieren, studenten en dienstplichtige miljtairen en dan is er nog de groep 'werkzaam in eigen ltuishouding', vrouwen zonder beroepsarbeid en zonder partner.

Met name de laatste groep kan niet zomaar uit onze analyse verdwijnen; volgens ons model zullen ze een hogere klachtenscore vertonen en vormt hun positie een essentieel onderdeel in het te construeren model.

Men kan nu twee wegen volgen: ook deze groepen kunnen in de toch al heterogene midden-categorie worden ondergebracht. Men kan ook proberen de status van deze groep te schatten in een hulpmodel. Het laatste is netter: het is echter de vraag of het uiteindelijke verschil te merken zal zijn. Dat kunnen we echter pas aan de analyseresultaten zien

Het hulpmodel is als volgt geconstrueerd:

Uit de variabelen: 'netto-inkomen van het gezin', 'aantal jaren opleiding'; 'aantal duurzame gebruiksgoederen' en een welstandsindicator samengesteld uit de waarde van de woning of de hoogte van de huur en de bouwtechnische toestand is voor jongere en oudere gehuwde vrouwen (jongeren en ouderen apart omdat er grote generatie-verschillen in het verband tussen schoolopleiding en status bestaan) een statusscore geschat. (Schattingen en operationaliseringen vindt men in bijlage B). Aan de categorie net ontbrekende score is met behulp van de schattingsparameters een nieuwe score toegekend.

\section{Niet meer gehuwd zin en niet meer werken}

Uit het Leef Situatie Onderzoek zijn op eenvoudige wijze de door ons gekozen suboptimale situaties af te leiden. "Werkeloos" en "WAO'zijn respectievelijk categorie 1 en 2 van de variabele 'activiteitencategorie'. De categorieën 2 (weduwe of weduwnaar), $3+4$ (gescheiden van echt en gescheiden van tafel en bed) vara de variabele "burgerlijke staat" zijn eveneens direct te gebruiken. 


\section{Normatieve integratie}

Drop (1979) gebruikt in haar studie naar verschillen tussen gemeenten en frequenthes van afwijkend gedrag de volgende indicatoren voor normatieve integratie: $\%$ onkerkelijken per gemeente; \% allochtonin; en en coéfficient voor de sociale diversiteit (Drop, 1979, 119). Naast deze maten voor normatieve integratie spelen ook de begrippen 'sociaal volume' en 'fysieke dichtheid' (resp. het anatal inwoners en de bevolkingsdichtheid) in haar onderzoek een belangrijke rol. Zoals gezegd. ontbreekt helaas in het LSO 77 een aanduiding over de geboorteplats van de respondent. Wel is gevraagd naar kerkbezoek en kerkelijke gezindte en zujn bovenclien enkele vragen gesteld over de mate warin men zich in zijn directe socialle omgeving opgenomen acht. Eén vraag is gesteld over het soort mensen in wier omgeving men woont ('mensen zoals ik, geheel andere mensen, gemengd') en éen vraag naar het aantal contacten per week met buturtgenoten. De scores van deze twee vragen zijn bij elkaar geteld tot de variabete "integratie’. (De index loopt van 1 -9 van zwak tot sterk geintegreerd).

Gezien de te verwachten hoge correlatie tussen het aantal inwoners per woongemeente en de bevolkingsdichtheid als contextuele variabelen (hoe groter de gemeenten hoe meer individuen in de steekproef - grote gemeenten met veel inwo. ners en een stedelijke (dus grote) bevolkingsdichtheid) tellen zwaarder mee) is voor eén van beide variabelen gekozen. In Drop haar onderzoek blijkt wooral het inwonertal een belangrijke variabele te zijn; hat hypothesen over relaties tussen afwijkend gedrag en fysieke dichtheid zijn niet tegen toetsing bestand. (Dtop, 1979 . 153-155). We hebben daarom inwonertal als variabele gekozen; gezien de grote fluctuaties is dit getal logarithmisch getransformeerd.

\subsubsection{De afhankelijke variabelen in het model}

Slechle gezondheid/chronische" ziekte

In het Leef Situatie Onderzoek is uit een combinatie van scores op de vragen naar lichamelijke aandoenimgen de variabele 'gezondheidstoestand' geconstrueerd (CBS, 1978, 89 en 135,136 , zie ook noot 32 van dit hfdst.). In noot 32 is al gezegd dat de constructie van deze variabele door het CBS nogal wat wragen oproept. Zo kan men, om een extreem voorbeeld te nemen, de code "lang ziek" toegewezen krijgen als men bijvoorbeeld "een enkele keer en langer dan 3 maanden" last heeft van spataderen of aambeien, dan wel volgens de interviewer thardhorend is, slecht ziet ook zonder bril of een sprakgebrek heeft'. Daarentegen levert de score (als hij) zou voorkomen) "een enkele keer en korter dan 3 manden" voor hartafwijking. beroerte of kanker de code 'kort ziek' op.

In de totale onderzoekspopulatie $(n=4159)$ lis op deze wijze $46 \%$ van de ondervraagden van 15 jaar en ouder 'lang ziek' (CBS, 1978, 89 tabel 4.1); 52\% van de vrouwen en $39 \%$ van de mannen.

Aangezien de door ons gewenste operationalisering van 'gezondheidstoestand" zo onathankelijk mogelijk moet zijn van zaken als 'neiging tot klagen op uitnodiging" 
(zij thet dat in een onderzoek volgens de vragenlijstmethode een strikte scheiding wan beide begrippen niet mogelijk is) en dus een zo 'hard' mogelijke operationalisatie van het begrip "gezondheidstoestand' dient te bevatten hebben we een poging gedaan enige schifting in de gepresenteerde lijst van aandoeningen aan te brengen. Als een eerste poging (met dank aan A. Bartelds, huisarts, oud medewerker N.H.I.) hebben we de aandoeningen naar mate van ernst en hinder in drie categorieèn laten indelen.

Tabel 6.2.: Mate van ernst en hinder wan 26 in het LSO 77 gebruikte aandoeningen ${ }^{44}$ )

\begin{tabular}{|c|c|c|}
\hline $\begin{array}{l}\text { categorie 1.: lichtie } \\
\text { hinder/ermst }\end{array}$ & $\begin{array}{l}\text { categorie 2.: matige } \\
\text { ernst/hinder of afh. } \\
\text { wan persoon dan wel } \\
\text { fase van de aandoening }\end{array}$ & $\begin{array}{l}\text { categorie } 3 . \text { ernstig } \\
\text { of zeer hinderlijk }\end{array}$ \\
\hline $\begin{array}{l}\text { 3. neus-bijholte- } \\
\text { ontsteking } \\
\text { 7. spataderen } \\
\text { 8. aambeien } \\
\text { 10. 'Andere maagklachten } \\
\text { dan maagzweer of zweer } \\
\text { 12-v.darm' } \\
\text { 11. dikke darmstoornissen } \\
\text { diarrhee of andere } \\
\text { buikklachten } \\
\text { 15. chronische blatasont- } \\
\text { steking } \\
\text { 17. verzakking (alleen } \\
\text { voor vrouwen) } \\
\text { 24. chronische huidziekte, } \\
\text { eczeem }\end{array}$ & $\begin{array}{l}\text { 5. hoge bloeddruk } \\
\text { 9. maagzweer of zweer } \\
\text { 12-vingerige darm } \\
\text { 12. galstenen of andere } \\
\text { gablaas en leverziekte } \\
\text { 13. breuk } \\
\text { 14. nierstenen } \\
\text { 16. prostaatklachten } \\
\text { (alleen mannen) } \\
\text { 19. schildklierafwijking } \\
\text { 20. rugaandoening van hard- } \\
\text { nekkige aard; hernia } \\
\text { 21. rineumatische gewrichts- } \\
\text { pijnen, met koorts } \\
\text { (vliegende rheumatiek), } \\
\text { slijtage van gewrichten, } \\
\text { gewrichtsrheuma } \\
\text { 23. migraine of ernstige } \\
\text { hoofdpijn }\end{array}$ & $\begin{array}{l}\text { 1. asmma/chronische } \\
\text { bronchitis } \\
\text { 2. TBC } \\
\text { 4. hartafwijking } \\
\text { 6. beroente en gevolgen } \\
\text { van een beroerte } \\
\text { 18. suikerzickte } \\
\text { 22. epilepsie of andere } \\
\text { toevallen } \\
\text { 25. gezwelworming of } \\
\text { kanker } \\
\text { 26. ernstige gevolgen } \\
\text { van een ongeval } \\
\text { zoals breuken of } \\
\text { ernstige brandwonden }\end{array}$ \\
\hline
\end{tabular}

Voor de constructie van de variabele "chronisch ziek" zijn de in categorie 1 genoemde aandoeningen buiten beschouwing gelaten evenals de door het CBS meegetelde door de interviewer genoteerde handicaps (slechthorend, slechtziend en lijdend aan 
een spraakgebrekj; de aandoeningen in de tweede categorie zijn meegeteld als ze de score 4,5 of 6 (vaker dan een enkele keer) vertoonden; de aandoeningen in categorie 3 (de meest serieuze) zijn meegeleld als er iets anders dan 'neen' was geantwoord op de vraag of men de laatste 12 maanden last van de betrokken aandoening heeft gehad.

De wariabele "chronisch ziek' kreeg de waarde ' 1 " als volgens bovenstatand model ến van de aandoeningen uit de middencategorie score 4,5 of 6 of eén van de aandoeningen uit de $3 \mathrm{e}$ categorie een score groter dan 0 vertoonde. Volgens bovenstaande berekening is $32.67 \%$ var de bevolking van 15 jaar en ouder "chronisch ziek".

\section{Klachtenlijsten: $A B V-N$ en VOEG}

Over de $A B V-N$ kunnen we kort zijn. Op de magneetband met het materiaal van het Leef Situatie Onderzoek waren de afzonderlijke items niet gecodeerd; alleen de totaalscore in klassen. Ook in de rapportage van de kerncijfers van het onderzoek (CBS, 1978) wordt deze neuroticisme-score niet genoemd. We hebben daarom de scores ongewijzigd gebruikt - in de analyse zijn de ontbrekende waarden (1.2\%) aan het groepsgemiddelde gelijk gemaakt.

De scores op de VOEG zijn door ons enigszins gemodificeerd, omdat in het oorspronkelijke onderzoeksmateriaal de score op de VOEG (21 items) als 'ontbrekend" was geclassificeerd indien men éen of meer van de samenstellende onderdelen niet had ingevuld. (Het gaat hier om 131 gevallen: $3.15 \%$ van hell totaal). Nadere analyse van het aantal ontbrekende items wees uit dat het voor het grootste deel incidentele weglatingen betrof (van de 131 ontbrekende gewallen was in $69 \%$ sprake van één, in $15 \%$ van twee, in $5 \%$ van drie en in $3 \%$ van vier of meer ontbrekende waarden).

De ontbrekende scores zijn als "klacht" geteld (als er althans niet meer dan 4 ontbraken). ${ }^{45}$ De uiteindelijke afhankelijke variabele in het model omvat ook deze ontbrekende, gehercodeerde waarden.

Tot zover de manipulatie met de gegevens; we zijn nu toe aan de specificatie van het model.

\subsection{Specificatie van het model}

Voor een goed begrip van onze werkwijze is het zinvol om het in hoofdstuk 5 gepresenteerde schema voor de geest te halen, maar nu met alle in het model opgenomen variabelen. 
Figutr 6.1: Schematisehe weergave-model vertaring van lichamelike wachen

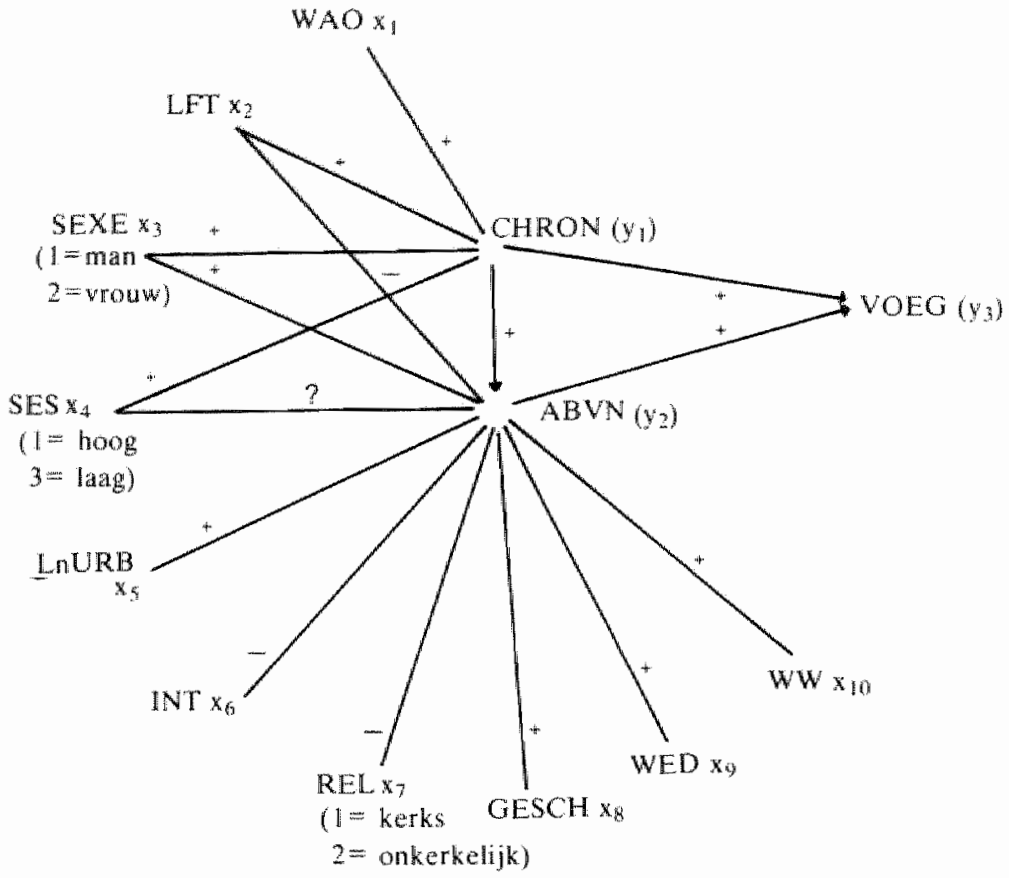

Wij definiëren drie afhankelijke variabelen:

"chronisch ziek"

$=y_{1}($ not. CHRON)

'ABV-N"

$=y_{2}($ not. $A B V N)$

'VOEG'

$=y_{3}$ (not. $\left.V O E G\right)$

en tien onafhankelijke (gepredetermineerde) variabelen)

WAO

Leeftijd

Geslacht

Soc. Ec. Status

inworters gemeente

integratie in butrt

godsdienst

gescheiden

weduwe/weduwnar

werkeloos $=x_{i}$ (not. WAO)

$=x_{2}$ (not. LFT)

$=x_{3}$ (not. SEXE)

$=x_{4}$ (not. SES)

$=x_{S}$ (not. LnURB)

$=x_{6}($ not. INT)

$=x_{7}$ (not. $\left.\mathbb{R E L}\right)$

$=x_{8}($ not. GESCH $)$

$=x_{i}($ not. WED)

$=\mathrm{x}_{10}($ not. WW $)$ 
We onderstellen

$y_{1}(C H R O N)$ afhankelijk van $x_{1.4}$

$y_{2}(A B V N)$ afhankelijk van $y_{\Perp}$ en $x_{1.40}$

$y_{3}$ (VOEG) afhankelijk van $y_{1-2}$

Formeel luidt dit model:

$y_{1}=f_{1}\left(x_{1}, \ldots, x_{4}\right)+\varepsilon_{1}$

$y_{2}=f_{2}\left(x_{1}, \ldots, x_{10}, y_{1}\right)+\varepsilon_{2}$

$y_{3}=f_{3}\left(y_{1}, y_{2}\right)+\varepsilon_{3}$

waarbij $\varepsilon_{i}(i=1,2,3)$ de verstoringstermen zijn.

We hebben geen reden om andere dan lineaire relaties te onderstellen dus:

$y_{1}=a_{1}+b_{1} x_{1}+\ldots+b_{4} x_{4}+\varepsilon_{1}$;

$y_{2}=c_{1}+d_{1} x_{1}+\ldots+d_{i} x_{i}+e_{1} y_{1}+\varepsilon_{2}$;

$y_{3}=f_{1}+g_{1} y_{1}+h_{1} y_{2}+\varepsilon_{3}$;

In de tweede vergelijking zullen coëfficiënten nul moeten zijn. We nemen a priori aan dat niet alle afhankelijke variabelen met alle onafhankelijke variabelen zullen samenhangen, hetgeen om redenen van identificatie der vergelijkingen noodzake lijk is (voor vergelijking $(2) i \leqslant 9$ ).

Men bedenke dat deze specificatie inhoudt, dat er 10 onafhankelijke, gepredetermineerde variabelen zijn en 3 afhankelijke.

In het algemeen zijn de door ons als gepredetermineerd opgevoerde variabelen niet alleen in technische, maar ook in theoretische zin onafhankelijk. Uitzonderingen zijn: de variabele WAO; in het algemeen gesproken wordt men niet chronisch ziek van arbeidsongeschiktheid, maar omgekeerd. In dit model echter (dat geen verklaring van het verschijnsel arbeidsongeschiktheid probeert te geven) zijn alle variabelen die wèl expliciet als onafhankelijk zijn gedefinieerd per definitie gepredetermineerd. Ditzelfde geldt voor de variabele: 'gescheiden'. Er zijn legio theorieën die op een precies omgekeerde manier het verband tussen geestelijke gezondheid en burgerlijke staat beschrijven. Ook hier geldt dat voor ons doel, in modeltechnische zim, het juist nodig is de betreffende variabele als gepredetermineerd op te voeren.

\subsection{Resultaten}

Drie variabelen zijn in onze analyse van bijzonder belang: "slechte gezondheid", 'emotionele labiliteit" en 'lichamelijke klachten', achtereenvolgens geoperationaliseerd in de variabelen "chronische aandoening" (notatie: CHRON), de (Neuroticisme) subschaal van de Amsterdamse Biografische Vragenlijst (notatie: ABVN) en de verkorte versie van de Vragenlijst voor Onderzoek van de Ervaren Gezondheidstoestand (notatie: VOEG). 
In deze volgorde zullen we ook paragraafsgewijs schattingsresultaten presenteren.

\subsubsection{Chronische zickle}

In paragraaf 6.3.2. is al witeengezet hoe we de variabele 'Chron' hebben geconstrueerd. Het is een wariabele die de waarde van 0 en $1 \mathrm{kan}$ aannemen; het gemiddelde geeft de proportie chronisch zieken in de steekproef weer.

In onze theoretische overwegingen hebben we geformuleerd dat de proportie personen met een chronische aandoening een functie is van leeftijd (notatie: LFT), geslacht (notatie: SEXE) en sociaal economische status (notatie: SES). We hebben a priori geen reden om af te wijken van de assumptie dat de relaties lineair en additief zouden zijn; de geringe hoeveelheid variabelen in het model maakt onderzoek naar niet-lineaire relaties of interactie-effecten echter goed mogelijk.

De belangrijkste relatie is het verband tussen chronische aandoening en leeftijd. Vervolgens bezien we het verband tussen leeftijd en slechte gezondheid voor mannen en vrouwen en voor de drie status-categorieën.

Figuur 6.2: Grafische weergave*) wan de proportie personen met chronische aandoening per leeftijdscategorie voor personen van 15 jaar en ouder $n=4157$ (leeftijd in 13 5-jaarsklassen) Leef Situatie Onderzoek 1977

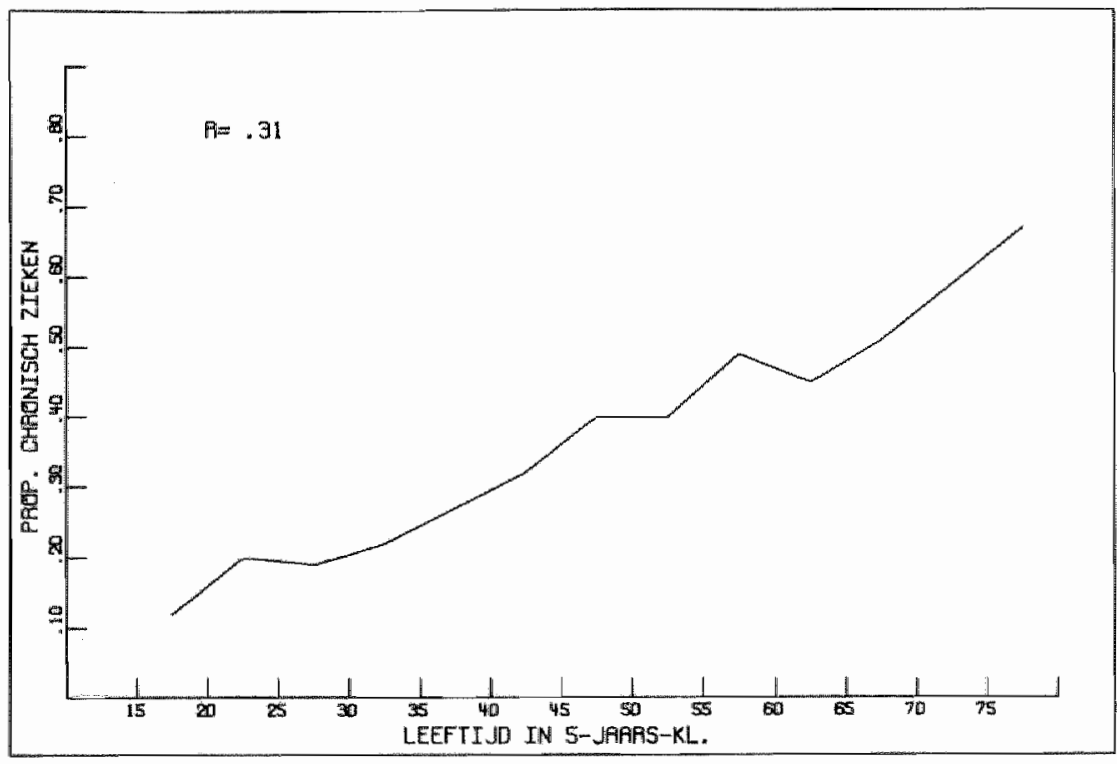

*) de bij figuur $6.2,-6.8$ behorende waarden zijn vermeld in bijlage $C$. 
Toets op lineairiteit levert geen afwijking op. Voor de steekproef als geheel is er sprake van een min of meer rechtlijnig verband tussen leeftijd en de kans op een chronische aandoening. De product-moment correlatie tussen leeftijd in jaren en de variabele chronisch ziek bedraagt voor de 4157 individuen: 310 en verschilt nauwelijks van de correlatiecoëfficiënt met leeftijid in klassen.

Voor mannen en vrouwen ziet het verband er als volgt uit.

Figuur 6.3: Grafische weergave van de proportie mannen respectievelijk vrouwen met chronische aandoening per leeftijdscategorie (leeftijd in 135 -jaarsklassen) Leef Situatie Onderzoek $1977 n=4157$.

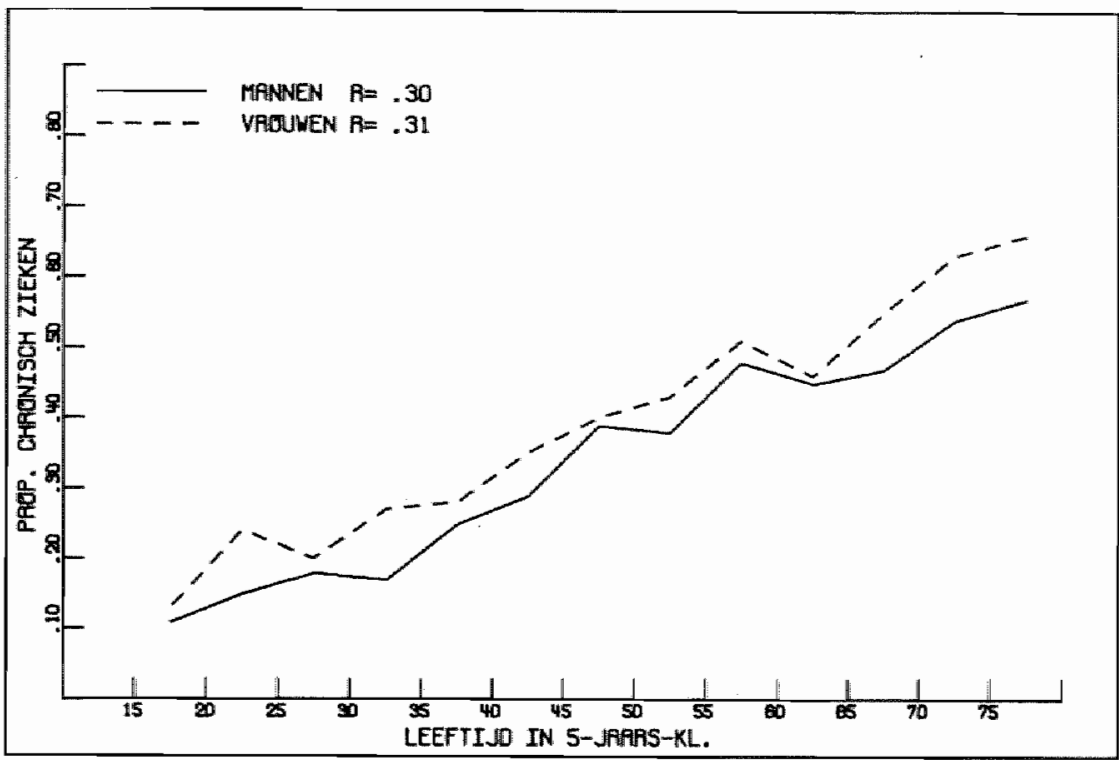

De lichte afwijking van de rechte lijn uit de vorige grafiek voor de leeftijdsgroep 20-24 jaar blijkt voor rekening van vrouwen te komen; de fluctuaties tussen 55 en 64 jaar gelden voor mannen en vrouwen gezamenlijk.

Vanaf 60 jaar gaan de proporties voor mannen en vrouwen sterk van elkaar verschillen; aangezien het hier prevalentie-cijfers betreft, zou de hogere sterfte onder mannen wel eens de oorzaak van dit groter wordende verschil kunnen zijn.

De rellatie met status moeten we in iets beknopter vorm laten zien. Door helt naar verhouding geringe aantal personen in de hoogste status-categorie moeten we leeftijd niet in 5-jaarsklassen maar in 10-jaarsklassen indelen om voldoende grote aantallen per categorie over te houden. In figuur 6.4. zijn de relaties grafisch weergegeven. 
Figutir 6.4: Grafische weergave van de proportie personen met chronische aandoening per status-ategoric en le eftijdsklasse (zes 10-jaarskassen) in het LSO $1977 \mathrm{n}=$ 4157.

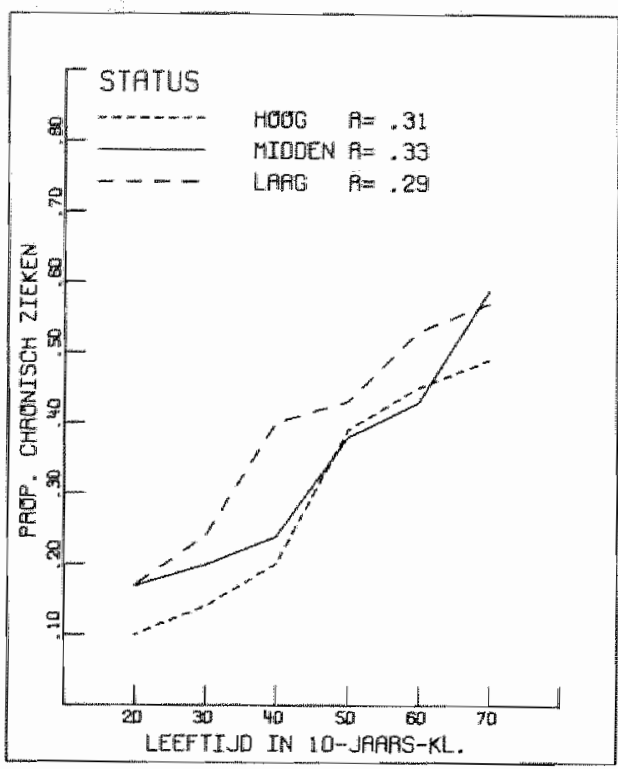

Het meest opvallende in de grafiek zijn de grote verschillen in de leefrijdscategorie 35-44 jaar (bijna dubbel zoveel chronisch zieken bij personen met lage status dan bij de overigen) en het geringe verschil in de volgende leeftijdsca tegorie. Mannen en vrouwen in de laagste statuscategorie vertonen 20 'n 10 jar eender slijage-verschijuselen, mar ook in de hogere en midden-wategorie is een klene veertig procent wan de personen tussen de 45 en 54 jaar chronisch of langdurig ziek.

Gen uigevoerde multiple classificatie-analyse geet an dat er sprake is van een interactio-effect tussen status en leefijd. Het ondetstelde lincaire model gaat her niet helemal op. In sommige cattegorieen vind then ex hogere of lagere proportie dan men op grond van en lineare relatie zou verwachten.

Inspectie van de figurr 6.4. leert dat de "uitschieters' in de leeftijdsgroep 35-44 jaar bij personen met een lage status warschijnlik dit interactiemeffeet veroorzaken. Dit wondt des te duidelijker als de midden-categorie even wordt weggelaten. 
Figuur 6.5:- Grafische weergave van de proportie personen met chronische aundoening voor personen met hoge en lage status per leeftijdsklasse (zes 10 - jaarsklassen) LSO 1977.

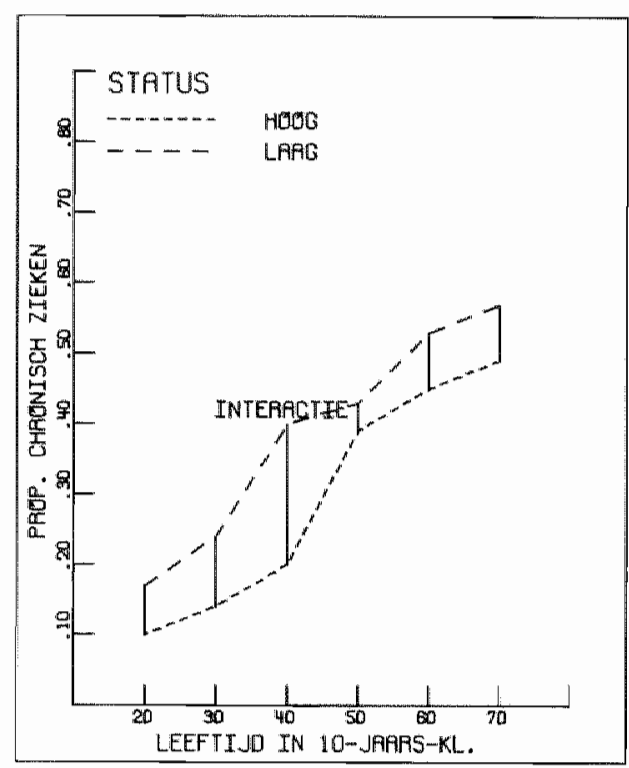

Per status en leeftijdscategorie zijn ook verschillen tussen mannen en vrouwen te constateren (figuur 6.6.-8.).

Bij de inspectie van de grafieken moet men bedacht zijn op kleine aantallen jongeren (15-24 jaar) en ouderen in de hoogste status-categorie. Desondanks is het grote uitgangsverschil bij vrouwen in de jongste leeftijdsgroep (status hoog $0 \%$ chronisch ziek, status laag $23 \%$ ) opvallend. (Een verschil in het tijdstip waarop men het eerste kind ter wereld brengt, wellicht).

\section{Schatringsresultaten}

Na deze illustraties keren we weer terug naar ons model. Het wordt nu tijd om de algemene modelspecificatie te verbijzonderen.

De in paragraaf 6.3. geformuleerde groep van gepredetermineerde variabelen word met een interactie-term $\left(x_{11}\right.$ : not - D 1) uitgebreid (een combinatie van leeftijd tussen de 35 en 44 jaar en lage status). Wij hebben al geformuleerd dat. $x_{1}$ (Leeftijd: LFT), $x_{2}$ (Geslacht: SEXE) en $x_{3}$ (Status: SES) in de structuurvergelijking zullen worden opgenomen. De interactie-term $\left(x_{11}\right.$ : D1) komt hier nog bij en 
Figuur 6.6. 6.8.: Grafische weergave van de proportie personen met chronische aandoeningen voor mannen en vrouwen per status en leefrijdscategorie (zes 10jaarsklassen) LSO 1977.
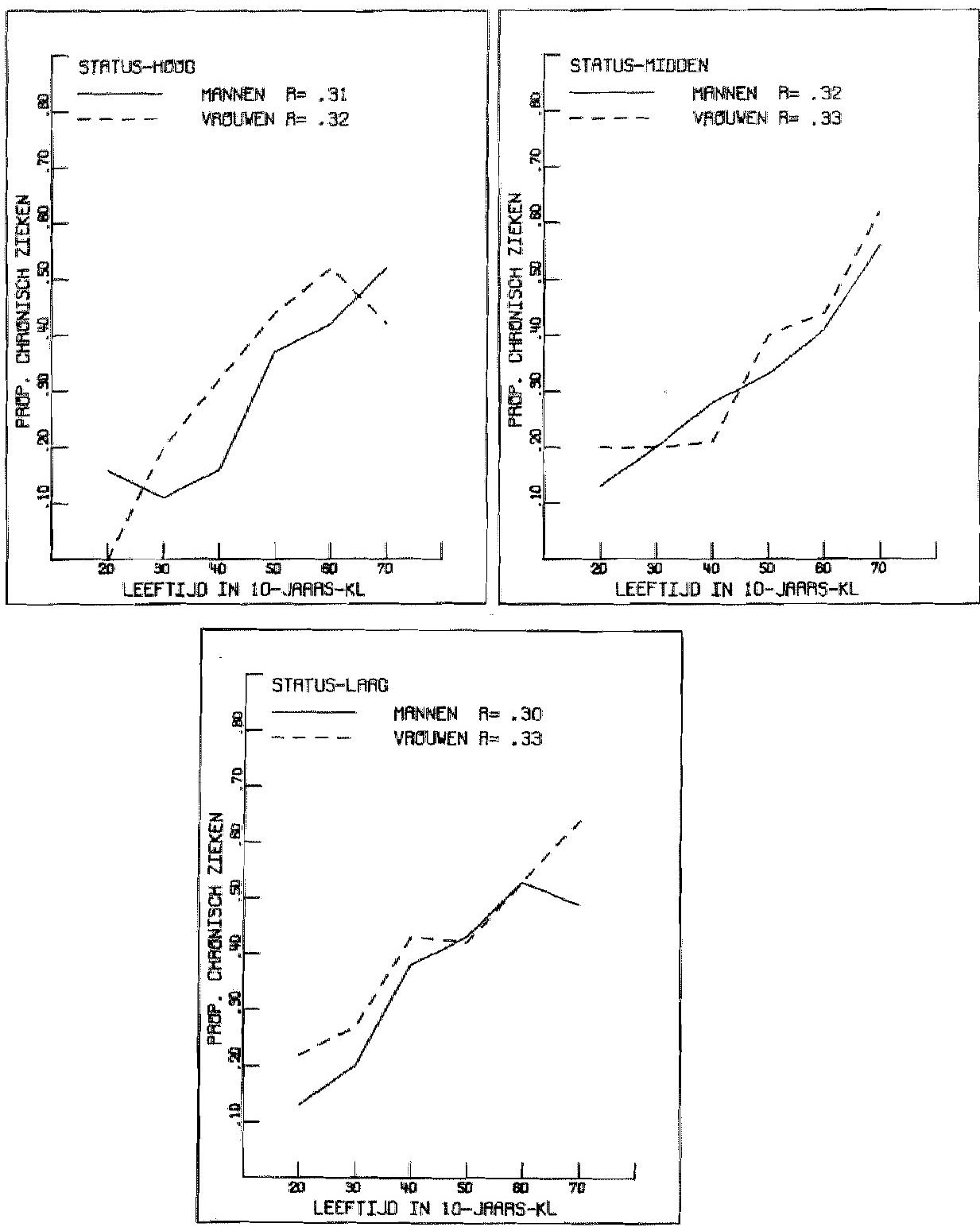
bovendien willen we de variabele 'WAO' ook in de siructuurvergelijking opnemen. Dat is niet zo elegant; we hebben al gesteld dat men niet "chronisch ziek" wordt van arbeidsongeschiktheid, maar omgekeerd. Aangezien we slechts drie aflankelijke variabelen in ons model hebben geformuleerd (CHRON, ABVN en VOEG) zijn de overige variabelen per definitie gepredetermineerd.

Tabel 6.3: Schattingsresultaten structuurvergelijking chronisch ziek. Gewone kleinste kwadraten. Leef Situatie Onderzoek $1977 \mathrm{n}=4157$. T-waarden met een significantie van $p<.05$ zijn schuin gedrukt.

\begin{tabular}{lccccccc}
\hline Variabelen & CHRON & LFT & SEXE & SES & WAO & D1 & CONST \\
\hline Min-Max waarde & 0.1 & $15-96$ & $\begin{array}{c}1-2 \\
(1=\text { man })\end{array}$ & $\begin{array}{c}1-3 \\
(1=\text { hoog })\end{array}$ & $0-1$ & 0.1 & \\
\hline Geniddelde & .33 & 42.32 & 1.50 & 2.24 & .03 & .07 & \\
\hline Standatarddev. & .47 & 17.98 & .50 & .73 & .17 & .25 & \\
\hline B-coëfficiënten & & .0077 & .059 & .030 & .33 & .076 & -.17 \\
\hline Standaardldev. & & .00038 & .014 & .0099 & .041 & .029 & .033 \\
\hline T-waarde & 20.16 & 4.27 & 3.05 & 7.95 & 2.65 & 5.23
\end{tabular}

Schattingsparameters Mult. $\mathrm{R}=.34 \mathrm{R}^{-2}=.12 \quad \mathrm{~N}=4157$

\section{Commentaar}

Weliswar is de proportie verklaarde variantie laag, maar de schattingsresultaten bevestigen het beeld van de grafieken.

Ten eerste (maar dat kan men niet in de tabel zien omdat hier alleen de structuurvergelijking, dat wil zeggen alleen de set van significante en relevante variabelen, wordt gepresenteerd: in bijlage $C$ stat de volledige vergelijking) zijn dit de enige van de 11 gepredetermineerde variabelen die met iemands slechte gezondheid samenhangen. Dat wil zeggen dat, vergeleken met gehuwde of altijd ongehuwd geweest zijnde personen, gescheidèn en verweduwde personen niet ongezonder zijn dan op grond van de combinatie van hun waarden op de variabelen in de verge lijking (leeftijd, geslacht, status, WAO en een extra gewicht voor personen van lage status in de leeftijdsklassen van 35-44 jaar) verwacht kan worden.

Dat geldt ook voor werkelozen: die zijn ook niet ongezonder dan anderen: nogmaals gegeven hun leeftijd, geslacht en sociaal economische status.

Ten tweede is het vooral leeftijd en zijn het in weel minder sterke mate de andere variabelen die de opgegeven gezondheidstoestand bepaten; daamaast vinden we, 
conform onze verwachtingen dat vrouwen een slechtere gezondheid hebben en dat personen uít de hoogste status-categorie een betere gezondheid hebben dan personetn uit de laagste categorieën.

Personen uit de laggte status-categorie tussen de 35-44 jaar hebben een nog sllechtere gezondheid dan mem op grond van een (lineaire) combinatie van hun leeftijd en staius zou verwachten.

Men bedenke wel dat dit een lineair, additief model is, hetgeen betekent dat we de waarden van de variabelen in het model bij elkar op kunnen tellen (uiteraard gewogen woor hun aandeel in de verklaarde variantie).

In normat Nederlands gezegd; oudere vrouwen uit de laagste status-categorie hebben een veel grotere kans op een chronische aandoening, dan jongere mannen uit de hoogste status-categoric, om even de twee extreme groepen tegenover elkaar te stellen. Dit kan men met deze vergelijking witrekenen. De gemiddelde kans voor vrouwen van 60 uit de categorie "handarbeider" is gelijk aan. $0077 \times 60+.059 \times$ $2+.030 \times 3-.17=50 \%$. Voor een man van 30 uit de hoogste status-categorie bedraagt dit gemiddeld: $.0077 \times 30+.059 \times 1+.030 \times 1-.17=15 \%$.

Het aardige van dit model is, dat men nu een instrument in handen heeft om met behulp van eenvoudige en dikwijls bekende populatie-kenmerken een schatting van de verdeling van de meer ernstige somatische problematiek in een bevolkingsgroep te maken. In een (reken)model moet men dan, naast de bekende variabelen 'leeftijd' en 'geslacht' ook een maat voor de sociaal economische status van de bevolking opnemen.

\subsubsection{Emovionele labiliteir}

Volgens ons model zou de ABV-score samen moeten hangen met alle gepredetermineerde variabelen en met de variabele 'chronisch ziek'. Dit makt schatting niet eenvoudig; omdat 'CHRON' zelf ook beïnvloed wordt door een aantal van de gepredetermineerden.

We zullen daarom verschillende schattingen laten zien. In tabel 6.4 worden er vier gepresenteerd.

Eerst ABVN met de 11 gepredetermineerde (exogene, onathankelijke) variabelen, dus zonder "chronisch ziek (CHRON)".

Vervolgens (in schatting 2) voeren we de op grond van de samenhang met de gepredetermineerde variabelen berekende variabele 'chronisch ziek, geschat' (notatie: CHRO) in. Van de gepredetermineerde variabelen moeten wij er tenminste Eén weglaten vanwege de identificeerbaarheid (schatting 2). ${ }^{46}$

De twee volgende schattingen ( 3 en 4 ) dienen voor het opstellen van een structuurvergelijking: de meest zinvolle en interpreteerbare lineaire combinatie van onathankelijke variabelen. 
Tabel 6.4.: Schattingsresultaten ABVN in het Leef Situatie Onderzoek 1977 $\mathrm{N}=4157$. Gewone kleinste kwadraten.

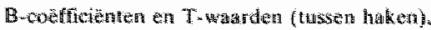
arsict bij $p<05$

\begin{tabular}{|c|c|c|c|c|c|c|c|}
\hline vartabelen & $\begin{array}{l}\text { Min-max } \\
\text { wiarcte }\end{array}$ & geniddalde & $\begin{array}{l}\text { standant- } \\
\text { deviatie }\end{array}$ & $\begin{array}{l}\text { schating } 1: \\
\text { ABWN met } \\
x_{1}-x_{\text {H }}\end{array}$ & $\begin{array}{l}\text { schating } 2: \\
\text { ABVW met } \\
3_{1} x_{3} x_{10}\end{array}$ & $\begin{array}{l}\text { schattigg } 3: \\
\text { ABwN met } \\
y_{3} x_{4}, x_{3}-x_{3} \text { 首 }\end{array}$ & 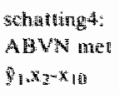 \\
\hline AENW $(y>)$ & $2-10$ & 3.55 & 1.73 & & & & \\
\hline CHRO $\left(\hat{Y}_{1}\right)$ & $.00 \% .99$ & 33 & .16 & n. & $\begin{array}{l}1.43 \\
11.000\end{array}$ & $\begin{array}{l}-.51 \\
(2.49)\end{array}$ & $\begin{array}{l}3.37 \\
(2,36)\end{array}$ \\
\hline WAO(x) & $0-1$ & .029 & .25 & $\begin{array}{l}1.17 \\
(7.45)\end{array}$ & $\begin{array}{l}.70) \\
(1.42)\end{array}$ & $\begin{array}{l}1.33 \\
(7.30)\end{array}$ & n.x. \\
\hline $\operatorname{LET}(x, y)$ & 15.96 & 42.32 & 17.98 & $\begin{array}{l}-0042 \\
(2.64)\end{array}$ & $\begin{array}{l}-.015 \\
(.436)\end{array}$ & n.k.t. & $\begin{array}{l}-.030 \\
7.2484\end{array}$ \\
\hline $\operatorname{SEXE}\left(x_{3}\right)$ & $\begin{array}{l}1-2 \\
1=\operatorname{lng}(1=1)\end{array}$ & 1.50 & .50 & $\begin{array}{l}48 \\
(6.43)\end{array}$ & $\begin{array}{l}39 \\
13.80\end{array}$ & $\begin{array}{l}.50 \\
19.27)\end{array}$ & $\begin{array}{l}27 \\
7499\end{array}$ \\
\hline $5 E S(x, f)$ & $\begin{array}{l}n-3 \\
\|=\text { hoog })\end{array}$ & $2 \cdot 4$ & .73 & $\begin{array}{l}.21 \\
(563)\end{array}$ & $\begin{array}{l}17 \\
(2.53)\end{array}$ & $\begin{array}{l}.24 \\
16.60)\end{array}$ & $\begin{array}{l}.095 \\
12.261\end{array}$ \\
\hline LnCPB $\left(x_{5}\right)$ & 6.8 .13 .5 & 10.51 & 1.44 & $\begin{array}{l}.057 \\
(3.02)\end{array}$ & $\begin{array}{l}053 \\
(2.73)\end{array}$ & $\begin{array}{l}.058 \\
(3.67)\end{array}$ & $\begin{array}{l}.447 \\
2.49)\end{array}$ \\
\hline $\operatorname{IN} \mathbb{R}\left(\mathrm{x}_{\mathrm{E}}\right)$ & $\begin{array}{l}1-9 \\
19= \\
\text { sterk }\end{array}$ & 483 & 2.28 & $\begin{array}{l}-.058 \\
(5,02)\end{array}$ & $\begin{array}{l}-.055 \\
4.00)\end{array}$ & $\begin{array}{l}-.059) \\
(5.11)\end{array}$ & $\begin{array}{l}-.051 \\
(4.38)\end{array}$ \\
\hline $\operatorname{REL}\left(x_{y}\right)$ & $\begin{array}{l}l-3 \\
(1=\text { kerks }) \\
(3=0 r k e r- \\
k \text { whj }\end{array}$ & $\$ .98$ & .73 & $\begin{array}{l}090 \\
(2067)\end{array}$ & $\begin{array}{l}089 \\
r 2.309\end{array}$ & $\begin{array}{l}104 \\
(2,83)\end{array}$ & $\begin{array}{l}074 \\
(2009)\end{array}$ \\
\hline $\operatorname{GESCH}(x)$ & 0.1 & .013 & 11 & $\begin{array}{l}1.02 \\
\{(1.45\}\end{array}$ & $\begin{array}{l}1.04 \\
(4.52)\end{array}$ & $\begin{array}{l}1.0 \% \\
(4.43)\end{array}$ & $\begin{array}{l}1.06 \\
(4.65)\end{array}$ \\
\hline WED $\left(x_{0}\right)$, & 0.1 & .066 & 25 & $\begin{array}{l}.52 \\
(450)\end{array}$ & $\begin{array}{l}54 \\
(4,50)\end{array}$ & $\begin{array}{l}.50 \\
(4.36)\end{array}$ & $\begin{array}{l}57 \\
(+40)\end{array}$ \\
\hline$W W(x+3)$ & 0.1 & 646 & .12 & $\begin{array}{l}844 \\
(3.460)\end{array}$ & $\begin{array}{l}66 \\
.4 .83\end{array}$ & $\begin{array}{l}.83 \\
(3.92)\end{array}$ & $(40)$ \\
\hline$D(x, 1)$ & 0.1 & 67 & .25 & $\begin{array}{ll}\| 11 \\
(1009)\end{array}$ & m.t.t. & A. I. I. & anct. \\
\hline COMSTANTE & & & & $\frac{193}{2.86}$ & $\begin{array}{l}2.23 \\
5.56\end{array}$ & $\begin{array}{l}1.79 \\
17.519\end{array}$ & $\begin{array}{l}2,646 \\
\left(9.9 \mathrm{~d}^{\mathrm{j}} \mathrm{j}\right.\end{array}$ \\
\hline \multicolumn{4}{|c|}{ Shlutingsparameters } & $\begin{array}{l}x^{2}=07 \\
n=4157\end{array}$ & $\begin{array}{l}K^{2}=-107 \\
n=4157\end{array}$ & $\begin{array}{l}R^{2}=.17 \\
n=4157\end{array}$ & $\begin{array}{l}n^{2}=207 \\
n=415 \%\end{array}$ \\
\hline
\end{tabular}

*) Voor de betekenis der afkortingen: zie pagina 58 . 


\section{Commentaar}

Schatting 1: ABVN met de $1 /$ gepredetermineerde variabelen (zonder ichronisch ziek')

Twee zaken vallen op: Ten eerste is de proportie verklaarde variantie nog lager dan bij de schatting van 'slechte gezondheid.' ( $7 \%$ ).

Kennelijk verklaren positionele en demografische factoren slechts een gering deel wan iemands score op een lijst met niet-lichamelijke klachten. Wat dat betreft vinden we hetzelfde resultaat als Ilfeld (1978) die een aantal maten van psychiatrische symptomatologie (waarin een lijst met psychische en lichamelijke klachten) in verband bracht met cen aantal demografische variabelen (teeftijd, geslacht, inkomem, opleiding, beroepsprestige, ras, burgerlijke staat). Ook hij kwam niet verder dan $7 \%$ verklaarde variantie. (11feld, 1978, 720).

Eén van de redenen is, dat de meeste van de door ons geselecteerde "suboptimale situaties' in een heterogene steekproef als van het Leef Situatie Onderzoek weinig vóórkomen. Slechts $1.56 \%$ van de ondervraagden geeft op werkloos te zijn; $1.32 \%$ is gescheiden; $6.59 \%$ verweduwd en $2.9 \rrbracket \%$ heeft via de WAO zijn werk verlaten. Ook al vinden we in deze groepen hogere klachtenscores, dan nog is de bijdrage aan de verklaring van de totale variantie gering. Bovendien is door ons ellke variabele waarvan maar enige kans bestond dat deze langs een andere weg "neiging tot klagen' zou meten uit het model geelimineerd. In het Leef Situatie Onderzoek is gevraagd naar werkomstandigheden, geluidshinder, opvattingen over het huishouden en tevredenheid met het leven in het algemeen en bepaalde sectoren in het bijzonder (zie Pommer en Van Pragg, 1978, Jol, 1980, Van de Willige en Ormel, 1979). We zouden zonder twijfel samenhangen met de ABV-N gevonden hebben als we deze variabelen ook hadden opgenomen. Wij menen echter dat vragenlijst-onderzoek niet geschikt is om een onderscheid tussen dergelijke nauwverwante begrippen te maken. Voor de onderzoeker het in de gaten heeft is hij bezig met een sofistisch spel waarin hij relaties vaststelt tussen verschillende vormen en uitingen wan onbehagen en onwelbevinden.

Ten tweede valt het op dat behalve de interactieterm, die is overgenomen uit de structuurvergelijking voor het verklaren van de variabele 'chronisch ziek', alle in het model opgenomen variabelen significant bijdragen aan de verklaring van de scores op de $A B V-N$. Wat dat betreft kunnen we zeker van een succes spreken. De t-waarden zijn in vele gevallen (geslacht, WAO, status, integratie, burgerlijke staat, werkloosheid) sterk tot zeer sterk. Inhoudelijk bezien, vallen de resultaten niet tegen.

Dit alles was echter zonder het invoeren van de variabele "chronisch ziek geschat". (Notatie: CHRO).

In schatting 2 zien we wat er gebeurt als we die variabele invoeren. In eerste instantie verslechtert het schattingsresultaat. Noch $\mathrm{CHRO}$ noch de belangrijkste determinanten ervan (LFT en WAO) vertonen nu een significante relatie met ABVN. Kennelijk is de onderlinge samenhang tussen deze drie zo sterk dat de 
bijdrage wan iedere variabele afzonderlijk wordt weggedrukt. (Multicollineairiteit). In schatting 3 en 4 hebben we dan ook achtereenvolgens LFT en WAO weggelaten. Dit verbetert de resultaten duidelijk.

In schatting 3 (zonder LFT) zien we dat chronisch zieken juist minder klagen als we rekening houden met de hoge samenhang tussen psychische klachten en arbeidsongeschiktheid wegens slechte gezondheid.

In schatting 4 klagen chronische zieken meer, maar oudere mensen juist weer minder. De combinatie jong en chrónisch ziek (en arbeidsongeschikt) geeft de meeste klachten. Dit is overeenkonstig onze verwachting. Als men oud is, aanvaardt men chronische ziekte waarschijnlijk als behorend bij thet bestaan; als men jonger is dan sluit een chonische aandoening vele 'normale' uitingsmogelijkheden aft.

Het is niet zo eenvoudig om uit de twee schattingen ( 3 en 4) een goede structuurvergellijking te kiezen. We prefereren (enigszins arbitrair) schatting 4 boven schatting 3 , omdat de negatieve coëfficiènt van 'leeftijd' (LFT) ons te interessant is, maar voor schatting 3 is ook wel wat te zeggen.

In tabel 6.5 zullen we schatting 4 , de structuurvergelijking, nog even naar voren halen.

Tabel 6.5.: Schattingsresultaten structuurvergelijking ABVN in het Leef Situatie Onderzoek 1977 , gewone kleinste kwadraten, $n=4157$ (voor de betekenis der afkortingen zie pag. 58). T-waarden cursief bij $\mathrm{p} \leqq 0.05$.

\begin{tabular}{|c|c|c|c|c|c|c|c|c|c|c|c|}
\hline Vuriabelen & CHLO & $\mathrm{LFT}$ & SEXE & SES & LnURB & $\mathrm{INT}$ & REL & $\mathrm{GESCH}$ & WED & $W W$ & CONSI \\
\hline Bwcostf. & 3.37 & $=030$ & 27 & .095 5 & .047 & -.05 & .074 & 100 & .57 & .89 & 2.66 \\
\hline St. deviatie & 46 & .0041 & .057 & 042 & 019 & .012 & .037 & .23 & .12 & .21 & .27 \\
\hline T"warate & 7.36 & 7.48 & 4.79 & 226 & 2.49 & 4.38 & 2.00 & 4.6 .5 & 4.90 & 4.19 & 9.94 \\
\hline $\begin{array}{l}\text { Schatings- } \\
\text { paramelers }\end{array}$ & \multicolumn{11}{|c|}{ mult:iple $R=.27 R^{-2}=.017 \mathrm{n}=4157$} \\
\hline
\end{tabular}

\section{Beschrijuing wan de schattingsresultaten}

Als we de resultaten nog eens kort beschrijven dan zien we, wat betreft de 'biogra" fische variabelen", dat ouderen inderdaad minder klagen als de invloed van hun, met hun leeftijd samenhangende slechte gezondheid is uitgeschakeld (het teken wan de coëfficiënt is negatief), dat wrouwen meer klagen dan mannen en dat personen met lage sociaal economische status meer klachten hebben dan personen uit de hogere sociale strata. Wij hadden bij het formuleren van onze verwachtingen de mogelijkheid geopperd dat evenals bij 'leeftijd' ook hier het teken van de coëfficiënt zou omslaan als rekening was gehouden met de slechtere gezondheid van personen uit de laagste statuscategorie; dit blijkt niet het geval te zijn; een lagere sociaal economische status betekent èn een slechtere gezondheid èn meer niet-lichamelijke 
klachten. Wat betreft "burgerlijke staat' zien we dat gescheiden personen en personen in de weduwstaat meer klachten hebben dan gehuwde of altijd ongehuwd geweest zijnde personen. Het gaat hier om mannen én vrouwen. Weliswaar zijn de scores voor gescheiden vrouwen en weduwen hoger dan voor mannen in vergellijkbare positie, matar dit komt omiat wrouwen-in-het-algemeen hogere klachtenscores hebben. Het gebruikte model is lineair en additief; voor vrouwen komt er gewoom .27 (de waarde van de regressiecoëfficiënt) bij. Het verschil tussen de coëfficiënt voor gescheiden personen (1.06) en de coëfficiënt voor weduwen en weduwnaars (.57) is significant. ${ }^{47}$ Gescheiden personen hebben meer klachten dan weduwen of weduwnaars en die hebben weer meer klachten dan gehuwde of altijd ongehuwd geweest zijnde personen.

Werklozen en arbeidsongeschikten klagen ook meer dan personen die werken, gepensioneerd zijn, studeren of een huishouden voeren. Arbeidsongeschikten hebben ook nog een slechtere gezondheid; voor werklozen geldt dat ze niet zozeer een slechtere gezondheid hebben, maar wel meer psychische klachten. Hoe groter de woongemeente is van de respondent hoe meer men klaagt. Voor personen uit Amsterdam (waarde wan het logaritmisch getransformeerde aantal inwoners = 13.5 ) wordt $13.5 \times .047=0.63$ bij hun klachtenscore opgeteld. Woont men in een dorp van 1000 inwoners (de kleinste gemeente in het bestand) dan krijgt men $6.8 \mathrm{x}$ $0.047=0.32$ (de helft) als bijdrage aan zijn klachtenscore.

De resultaten van het onderdeel 'integratie' zijn conform de resultaten van Drop (1979), ondanks het grote verschil in aggregatieniveau van beide onderzoekingen. In Drop haar onderzoek vormden 'gemeenten' de eenheid van analyse, het LSO 1977 is een persoonsenquête.

Is men kerks én kerkelijk dan heeft men minder klachten dan als men zich onkerkelijk noemt. Ook is het zo, dat personen die zich minder goed thuisvoelen in hun directe woonomgeving meer klachten hebben dan mensen die vinden dat in hun buurt dezelfde soort mensen wonen als zijzelf en ook regelmatig burtcontacten rapporteren.

Tenslotte wijzen we er nogmaals op dat een chronisch slechte gezondheid óok gepaard gaat met meer niet-lichamelijke klachten. We hebben al eens gesteld, dat een deel van dit resultaat wellicht kunstmatig is omdat in een vragenlijstonderzoek contaminatie nooit geheel te vermijden is; het lijkt ons echter onwaarschijnlijk dat we het geheel van de samenhang zo kunnen afdoen. Per slot van rekening hebben we slechte gezondheid ondergebracht bij de suboptimale, nauwelijks veranderbare, 'zeurende' problematiek.

Alles bij elkaar genomen zijn onze gevoelens gemengd. De geringe proportie verklaarde variantie maakt onze aanpak: eerst klachten verklaren en dan doktersbezoek, twijfellachtig.

De situaties die wij in het model opgenomen hebben blijken echter ondubbelzinnig te maken te hebben met het uiten van niet-lichamelijke klachten; wat dat betreft stemmen de resultaten tot tevredenheid. 


\subsubsection{Lichamelijke klachten (de VOEG)}

We zijn nu toe aan het tweede stadium van onze schatting: In dit stadium is iemands score op een lijst met lichamelijke klachten de te verklaren variabele; in dit geval de tot 21 vragen verkorte versie wan de VOEG.

In ons model is de zaak eenvoudig, we onderstellen alleen een relatie met de berekende variant van ABVN en CHRON ( $\widehat{A B V}$ en CHRO).

We hebben a priori geen redenen om te onderstellen dat én of meer van de gepredetermineerde variabelen nog een extra invloed op de VOEG zullen uitoefenen. In de praktijk zullen er, gezien de onvolmaaktheid van het model wel relaties te vinden zijn.

Bekijkt men de frequentieverdeling van de scores op de VOEG (zie bijlage $F$, waarin enkele basisgegevens voor in dit gedeelte uitgevoerde analyses staan vermeld) dan valt de lange 'staart" wan de verdeling op. Meer dan $90 \%$ van de mensen heeft een VOEG-score van 10 of lager. Onze schatringsmethode vergt een eliminatie van de extreme waarden. Voor het elimineren van deze extreme waarden zijn verschillende methoden: men kan de hoogste waarden in éen klasse onderbrengen (bijv. 12 en hoger optellen bij score 12) of een transformatie (worteltransformatie of een logarithmische transformatie) toepassen. De schattingsresultaten variëren weinig; de worteltransformatie geeft de beste uitkomsten (de verschillende transformaties staan in tabel 7 van bijlage $C$ ). In tabel 6.6. zien we de resultaten van de schatting in het tweede stadium.

Tabel 6.6.: Resultaten definitieve schatting 2e stadium. VOEG-score: $V$ (VOEG) en afhankelijke variabelen uit het eerste stadium. LSO 1977 gewone kleinste kwadraten.

\begin{tabular}{lccc}
\hline Variabelen & $\mathrm{ABV}$ & $\mathrm{CHRO}$ & Const \\
\hline B-coeff. & .32 & 1.18 & .46 \\
\hline $\begin{array}{l}\text { St. deviatie } \\
\text { T-waarde }\end{array}$ & .028 & .080 & .097 \\
\hline $\begin{array}{l}\text { Schattings- } \\
\text { parameters }\end{array}$ & 11.49 & 14.77 & 4.75 \\
\hline
\end{tabular}

Dit is dus het uiteindelijke resultaat van ons model. Iemands score op een lijst met lichamelijke klachten (de VOEG in dit geval) is een functie van iemands gezondheidstoestand en iemands emotionele labiliteit. Het blijkt mogelijk de beide com- 
ponenten te onderscheiden en met behulp van achterliggende factoren te verklaren. Men bedenke echter wél dat met name de proportie verkllatarde variantie in de ABVN gering is en dat we (dus) slechts een deel van de situaties warin men spanningen vertoont in kaart hebben gebracht, zoals we hieronder nog verder zullen uiteenzetten.

Dit heeft vooral gevolgen woor het verdere werloop van onze analyse. Als we een dusdanig gering percentage variantie verklaren van iemands lichamelijke klachten, dlan is het zinloos om in volgende stadia dáruit nog weer eens het bezoek aan of van de huisarts te verklaren.

We zullen bij de schatting van "doktersbezoek" niet de berekende versies wan $A B V N, C H R O N$ en VOEG moeten invoeren, maar de ongeschatte vorm.

\section{Overige variabelen}

Zoals al gezegd is het niet onwaarschijnlijk dat buiten de afhankelijke variabelen uit het eerste stadium ( $\mathrm{A} \widehat{\mathrm{B} V}$ en $\mathrm{CHRO}$ ) ook nog eén of meer van de gepredetermineerde variabelen invloed op de VOEG uitoefenen.

Wij hebben a priori geen argumenten om hierover voorspellingen te doen. Wij zullen daarom een stukje inductief werk aan onze voornamelijke deductieve studie toevoegen. Hiertoe zullen wij de relaties tussen $\vee$ VOEG enerzijds en $\widehat{A} \widehat{B} V$ en CHRO plus telkens éen van de gepredetermineerde variabelen anderzijds laten zien.

De resultaten vindt men in tabel 6.7. Men vindt in deze tabel telkens de B-coëfficiënten en $T$-waarden voor de berekende versies van $A B V N$ en $C H R O N$ ( $\widehat{A B V}$ en CHRO) èn de B-coëfficiënt en $T$-waarden van per regel een andere (links op de regel genoemde) onafhankelijke variabele.

Als eén van deze laatste coëfficiënten significant van nul verschillt (de $T$-waarde is dan cursief gedrukt), dan betekent dat, dat deze variabele buiten de in het model voorspelde relatie met $A B V N, C H R O N$ of beide nog een extra bijdrage levert aan het verklaren van de score op de VOEG.

Verschilt de coëfficiënt van de extra variabele niet significant van nul dan levert deze variabele $z$ 'n bijdrage alleen via de $A \widehat{B} V$ en $C H R O$ en draagt hij niet zelfstandig bij aan de VOEG.

Als het model volledig was dan zou geen van de coëfficiënten van de extra opgenomen variabelen significant moeten zijn. Vindt men wel een significante relatie dan geeft dit een aanwijzing waar we verder moeten zoeken als we meer variantie willen werklaren.

\section{Commentaar}

Laten we beginnen met de niet-significante coëfficiënten. De invloed van sociale status op iemands score ap een lijst met lichamelijke klachten loopt geheel via de variabelen in het model, nl. "slechte gezondheid" en 'emotionele labiliteit'. Datzelfde geldt voor arbeidsongeschiktheid (ook via èn 'slechte gezondheid' èn 'emotio- 
Tabel 6.7.: Schattingen 2e stadium - $/($ VOEG) met afhankelike variabelen wil het le stadium en telkens 1 van de gepredetermineerde variabelen. LSO $1977 \mathrm{n}=4157$ (voor afkortingen zie pagina 58 )

\begin{tabular}{|c|c|c|c|c|}
\hline $\begin{array}{l}\text { Afh var. }=\text { (VOEG) } \\
\text { Gepred.var. }\end{array}$ & $\begin{array}{l}\text { B-coeff } \\
(\mathrm{T}-\text { waarde }) \\
\mathrm{ABV}\end{array}$ & $\begin{array}{l}\text { B-coëff } \\
\text { (T-Wwarde) } \\
\text { CHRO }\end{array}$ & $\begin{array}{l}\text { B-coëff } \\
\text { (T-waarde) } \\
\text { Gepred. var. }\end{array}$ & $\begin{array}{l}\text { Const. } \\
\text { (T-watarde) }\end{array}$ \\
\hline LFT & $\begin{array}{r}.26 \\
(6.59)\end{array}$ & $\begin{array}{r}1.74 \\
(6.79)\end{array}$ & $\begin{array}{l}.0051 \\
(2.30)\end{array}$ & $\begin{array}{r}.71 \\
(4.81)\end{array}$ \\
\hline SEXE & $\begin{array}{r}.27 \\
(8.45)\end{array}$ & $\begin{array}{r}1.17 \\
(14.68)\end{array}$ & $\begin{array}{r}-.0097 \\
(3.33)\end{array}$ & $\begin{array}{r}50 \\
(5.20)\end{array}$ \\
\hline SES & $\begin{array}{r}.33 \\
(10.54)\end{array}$ & $\begin{array}{r}1.18 \\
(14.71)\end{array}$ & $\begin{array}{r}-.0072 \\
(.37)\end{array}$ & $\begin{array}{r}.45 \\
(4.70)\end{array}$ \\
\hline WAO & $\begin{array}{r}.32 \\
(11.07)\end{array}$ & $\begin{array}{r}1.18 \\
(13.79)\end{array}$ & $\begin{array}{r}-.012 \\
(.18)\end{array}$ & $\begin{array}{r}.46 \\
(4.45)\end{array}$ \\
\hline WW & $\begin{array}{r}.34 \\
(11.54)\end{array}$ & $\begin{array}{r}1.16 \\
(14.36)\end{array}$ & $\begin{array}{c}-.12 \\
(1.13)\end{array}$ & $\begin{array}{r}.43 \\
(4.38)\end{array}$ \\
\hline GESCH & $\begin{array}{r}.35 \\
(11.80)\end{array}$ & $\begin{array}{r}1.17 \\
(14.67)\end{array}$ & $\begin{array}{c}-.27 \\
(2.32)\end{array}$ & $\begin{array}{r}.38 \\
(3.77)\end{array}$ \\
\hline WED & $\begin{array}{r}.34 \\
(11.98)\end{array}$ & $\begin{array}{r}1.24 \\
(14.94)\end{array}$ & $\begin{array}{c}-.14 \\
(2.62)\end{array}$ & $\begin{array}{r}.39 \\
(3.91)\end{array}$ \\
\hline LnURB & $\begin{array}{r}.33 \\
(11.25)\end{array}$ & $\begin{array}{r}1.10 \\
(14.80)\end{array}$ & $\begin{array}{l}.0010 \\
(.11)\end{array}$ & $\begin{array}{r}.44 \\
(3.81)\end{array}$ \\
\hline INT & $\begin{array}{r}.33 \\
(10.99)\end{array}$ & $\begin{array}{r}1.18 \\
(14.64)\end{array}$ & $\begin{array}{r}.0005 \\
(.060)\end{array}$ & $\begin{array}{r}.45 \\
(3.96)\end{array}$ \\
\hline REL & $\begin{array}{r}.33 \\
(1 / .31)\end{array}$ & $\begin{array}{r}1.17 \\
(14.45)\end{array}$ & $\begin{array}{r}.0091 \\
(.51)\end{array}$ & $\begin{array}{r}.46 \\
(4.76)\end{array}$ \\
\hline
\end{tabular}

nele labiliteit') en voor werkloosheid (alleen via 'emotionele labiliteit', deze variabele had immers geen invloed op 'chronische ziekte'). Ook de variabelen uit de sfeer van (normatieve) integratie en religie leveren geen extra bijdrage aan de verklaring van de score op de VOEG. Als mensen lichamelijke klachten hebben is 
dit terug te woeren op klachten die een teken zijn van malaise en emotionele labiliteit. Dit geldt ook voor de verhoogde scores van mensen uit grote steden; ook deze hebben als basis een verhoogde score van psychische klachten. Of dit nu weer verwijst naar het leefklimaat in de grote steden of terug te voeren is op de geringere sociale controle of een weerslag is wan de aantrekkingskracht die grote steden op een bepaald soort mensen vitoefent of zelfs puur een kunstmatig effect is, dat wordt veroorzaakt door de geringe bereidheid tot medewerking aan de enquête in grote steden (zie Ormel's bewindingen dat wan zijn respondenten met een hoge neuroticisme-score weel meer personen bereid waren opnieww een vraggesprek te houden. dan van de personen met een lage neuroticisme-score), daarover kunnen en willen wij hier geen uitspraak doen, omdat het ons aan gegevens ontbreekt dit verder uit te zoeken.

Voor leeftijd, geslacht en burgerlijke staat vinden we wel significante relaties met de VOEG. Wat betreft 'leeftijd' is deze negatief; jongeren hebben blijkbaar meer lichamelijke klachten dan men op grond van hun gezondheidstoestand (die in het algemeen niet chronisch sllecht zal zijn) en hun emotionele labiliteit zou verwachten. Datzelfde geldt voor vrouwen. Bij burgerlijke staat hebben we te maken met negatieve coëfficiënten. Als men niet gescheiden is en geen weduwe of weduwnaar, dan heeft men meer lichamelijke klachten dan men op grond van gezondheidstoestand en score op de $A B V-N$ zou verwachten. Zou Walter Gove dan toch (ook) gelijk hebben? Men hoeft niet veel fantasie te hebben om de resultaten zo te interpreteren dat wooral jongere getrouwde vrouwen meer lichamelijke klachten hebben dan men op grond van hun gezondheidstoestand en $A B V N$-score zou verwachten. Gove vindt minder, wat hij dan noemt, geestelijke gezondheid bij gehuwde vrouwen; hijgaat daarbij uit van gegevens over, op welke wijze dan ook, behandelde gevallen. Hij komt daarbij tot het formuleren van een 'role specific theory of mental illness', waarin hij stelt dat het huwelijk voor mannen een beschermende functie heeft maar wan vrouwen in lichamelijk en geestelijk opzicht veel vergt.

Gezien de resultaten van onze analyse, die in eerste instantie het algemene beeld bevestigen dat juist personen die geen partner meer hebben meer spanningen vertonen dan personen met een partner of personen die mog nooit een partner hebben gehad, maar warbij in tweede instantie de lichamelijke klachten juist van de laatstgenoemde twee groepen niet afdoende kunnen worden verklaard, zullen wij in een extra paragraaf nog eens proberen deze tegenstrijdige resultaten aan een nader onderzoek te onderwerpen. 
6.5.4. De jachi op de 'groene weduwe', op zoek naar probleemsinuaties van jongere Inleiding gehuwde of allijd ongehuwd geweest zijnde vrowwen.

Voordat we op zoek gaan naar omstandigheden waaronder jongere gehuwde vrouwen lichamelijke klachten uiten, moeten we éen andere verklaring van cle gevonden resultaten op z'n plausibiliteit toetsen.

Alles zou immers ook nog 'gewoon' kunnen kloppen. In het geval namelijk dat er leeftijd-, generatie-, of cultuurgebonden neigingen zouden bestaan om eerder in termen van lichamelijke dan wel psychische klachten op situaties te reageren. Het zou kunnen zijn dat bijvoorbeeld jongere vrouwen meer geneigd zijn hun onbehagen in lichamelijke klachten om te zetten dan in de met de ABVN geoperationaliseerde psychische klachten.

Dit kunnen we, zij het indirect, wel toetsen.

Ten eerste kunnen we kijken naar de enkelvoudige correlatie tussen VOEG en ABVN voor deze groep in het bijzonder en voor de rest van de populatie. Ten tweede kunnen we de covariantie van VOEG en ABVN nog wat verder analyseren. In het geval dat de subgroep van jongere getrouwde en nooit gehuwd geweest zijnde vrouwen eerder lichamelijke dan niet-lichamelijke klachten zou uiten, zou de correlatie tussen beide typen klachten voor deze groep lager moeten zijn dan voor de rest van de populatie. Dit nu is niet het geval $\mathrm{r}_{\mathrm{ABVN}-\text { VOEG }}=.54(\mathrm{~N}=1101)$ voor gehuwde of ongehuwde vrouwen van jonger dan 45 jaar en voor de totale populatie $r=.51$.

Een nadere analyse (factoranalyse in dat geval - zie bijlage $D$ voor een beschrijving) van de VOEG levert een viertal intepreteerbare factoren op (als we een grens voor de Eigenwaarde van 1.0 aanhouden) namelijk een factor 'spijsvertering' (dat zall niemand verbazen - in de verkorte VOEG zijn de "maag-items" disproportioneel vertegenwoordigd), een factor 'malaise" (moe, lusteloos etc.), een factor 'thorax' (om een medische term te gebruiken - met items als 'benauwd op de borst", maar ook 'pijn op de borst' en 'hartkloppingen') en een factor 'bewegingsapparaat' (rugpijn, spierpijn).

De aard van de verkorte VOEG maakt de factor-oplossing tamelijk willekeurig, zij het dat de factor "malaise-klachten" waarschijnlijk de verbindende schakel vormt tussen de $A B V N$ en de meer orgaanspecifieke klachten uit de VOEG en dat het dubbelzinnige karakter van de VOEG hierop is terug te voeren. Als het nu zo is dat gehuwde en altijd ongehuwd geweest zijnde vrouwen een andler klaagpatroon vertonen, dan zouden de correlaties wan $A B V N$ met de verschillende subscores van de verkorte VOEG voor deze groep anders van aard moeten zijn dan voor de populatie als geheel.

Zijn de correlaties min of meer hetzelfde, dan kunnen we verder zoeken naar situaties binnen deze groep die samengaan met een hogere score op de ABVN. In tabel 6.8. staan de correlatie-coëfficiënten vermeld. 
Tabel 6.8: Correlatie-coêfficienten subscores VOEG met ABVN voor de populatie als geherl en wrouwen < 45 jaar-gehuwd of altijo ongehuwd geweest. LSO 1977.

\begin{tabular}{lcc}
\hline Subscore VOEG & getiele populatie & vrouwen geh. $<45$ jaar \\
\hline spijgvertering & .18 & .23 \\
malaise & .48 & .46 \\
thorax & .23 & .21 \\
bewegingsapparat & .20 & .23 \\
\hline VOEG-total & .51 & .54 \\
\hline
\end{tabular}

De belangrijkste correlatie tussen $A B V N$ en subscores VOEG is voor beide groepen de correlatie 'malaise' - 'ABVN". De gedachte dat de 'VOEG' bestaat uit een algemene spanningscomponent en een aantal aandoeningsgebonden klachten wordt met deze tabel overigens eveneens bevestigd.

Op grond van deze resultaten moeten we de hypothese dat jongere, gehuwde of nooit gehuwde vrouwen meer geneigd zouden zijn spanningen in lichamelijke dan in psychische klachten om te zetten in z'n algemeenheid verwerpen. Aangezien deze groep als regel geen chronisch slechte gezondheid heeft, moeten we verder zoeken naar factoren binnen deze groep die van invloed zijn op de tweede component: namelijk de met de ABVN geündiceerde 'emotionele labiliteit'.

\section{Probleemsinaties}

In de Sociale Atlas van de Vrouw (Meyer, 1977) staat op pag. 114 een tabelletje waarin de VOEG-scores (in deze Atlas opgevat als een maat voor 'stress') voor wel en niet werkende gehuwde vrouwen en voor gehuwde mannen worden vertoond (gegevens uit het Leef Situatie Onderzoek van 1974). Niet werkende gehuwde vrouwen een gemiddelde score van $3.1(\mathrm{~N}=1351)$, werkende gehuwde vrouwen van $2.7(\mathrm{~N}=361)$ en gehuwde mannen $(\mathrm{N}=1755)$ een gemiddelde van 2.6 .

Met de kennis die we nu bezitten over de opboww van de VOEG is het tamelijk onwaarschijnlijk dat deze scores bestand zijn tegen nadere toetsing.

Immers, werkende gehuwde wrouwen vormen bijvoorbeeld een jonge steekproef uit de populatie (gehuwde vrouwen werken vaak tot de geboorte van hun eerste kind en alle vrouwen van 65 jaar en ouder zijn "niet-werkend'). VOEG-scores mogen alleen als indicator woor 'sitress' worden gebruikt (of liever gezegd, als indicator voor onwelbevinden, want men zou ze beter in het gebeel niet als indicator voor 'stress' kunnen gebruiken) als met de (voornamelijk door leeftijd bepaalde) gezondheidstoestand van de groep is rekening gehouden. Maar, afgezien van de vraag of een dergelijk tabelletje zinvol te interpreteren valt (daar komen we nog wel op terug) wordt 'werk' blijkbaar, althans bij gehuwde vrouwen, als een heilzaam middel tegen 'stress' gezien. 
Wij zullen de groep jongere (jonger dan 45 jaar) gehuwde of altijd ongehuwd geweest zijnde vrouwen eens nader bekijken. Hoe zijn hun aktiviteiten werdeeld over huishouden en andere bezigheden; wat is de samenstelling van hun gezin, als ze een gezin hebben; in wat voor samenlevingswerband wonen ze als ze niet gehuwd zijn en, verschillen hun scores op een klachtenlijst onder al die verschillende omstandigheden.

In tabel 6.9. wordt eerst de verdeling van de vrouwen over de verschillende categorieën getoond. Bij de "bezigheden' hebben we onderscheiden: 'werkt full-time', 'part-time', "student' of 'zit op school" en 'huishouden'. Er is nog een restcategorie waarin vrouwen zitten, die werkloos zijn of voor het eerst werk zoeken, of arbeidsongeschikt zijn of een nog andere relatie met het arbeidsproces hebben. Bij "samenlevingsverband" is onderscheiden 'gezin zonder kinderen', "gezin met jongste kind 6 jaar of jonger", 'gezin met jongste kind ouder dan 6", 'alleenstaande', "thuiswonend kind" en "anders". In deze laatste categorie heeft men inwonende familie, in het gezin opgenomen personen die geen familie zijn etc.

Tabel 6.9.: Verdeling van de groep vrouwen jonger dan 45 jaar, gehuwd of altijd ongehuwd geweest over verschillende categorieën wan samenlevingsverband en activiteiten. LSO 1977.

\begin{tabular}{lllll}
\hline gezin & gezin & idem & alleen- & thuis- anders \\
zonder & jongste & $>6 \mathrm{jr}$. & staand \\
kind & kind & & & $\begin{array}{l}\text { konend } \\
\text { kind }\end{array}$ \\
& $<6 \mathrm{jr}$.
\end{tabular}

\section{werkt}

full-

73

15

19

41

86

7

24.

time

\section{werk}

part-

26

35

75

3

22

161

time

\begin{tabular}{lccccccc}
\hline studeert & 8 & & 1 & 10 & 120 & 6 & 145 \\
\hline $\begin{array}{l}\text { huis } \\
\text { houden }\end{array}$ & 31 & 309 & 242 & 1 & 2 & 1 & 586 \\
\hline anders & 9 & 17 & 7 & 5 & 11 & 4 & 53 \\
\hline Total & 147 & 376 & 344 & 60 & 241 & 18 & 1186 \\
\hline
\end{tabular}


Het is goed om te beseffen hoe heterogeen de geselecteerde groep in feite is, van thuiswonende kinderen tot moeders die zelf kinderen wan die leeftijd thuis hebben wonen. Bijna de helft wan de geselecteerde groep bestaat uit huisvrouwen (49.7\%) en ongeveer een derde (34.4\%) werkt in volledige of gedeeltelijke betrekking. We willen nu ABV-N-scores bekijken woor de $95 \%$ van deze groep die buiten de categorie "anders" valt. We hebben al laten zien hoe heterogeen deze laatstgenoemde categorie is. Ook de geringe celvulling bemoeilijkt de analyse.

We zullen eerst in tabel 6.10. de ongewogen gemiddelde scores per groep laten zien; de aantallen wijken iets af van de aantallen in tabel 6.9. omdat voor sommigen de scores op de $A B V-N$ niet zijn ingevuld. In cellen met 10 of minder personen is de $A B V-N$-score weggelaten; de kans op toevallige en niet interpreteerbare waarnemingen is hier te groot.

Tabel 6.10.: ABV-N-scores voor vrouwen jonger dan 45 jaar, gehuwd of altijd ongehuwd geweest naar samenlevingsverband en soort werkzaamheden. LSO 1977.

\begin{tabular}{lllll}
\hline gezin & gezin & gezin & alleen- & thuis- \\
zonder & jongste & jongste & staande & wonend \\
kinderen & kind & kind & & kind \\
& $<6 \mathrm{jr}$. & $>6 \mathrm{jr}$. & &
\end{tabular}

\begin{tabular}{|c|c|c|c|c|c|c|}
\hline $\begin{array}{l}\text { werkt } \\
\text { full } \\
\text { time }\end{array}$ & $\begin{array}{l}3.96 \\
(72)\end{array}$ & $\begin{array}{l}3.53 \\
(15)\end{array}$ & $\begin{array}{l}3.53 \\
(19)\end{array}$ & $\begin{array}{l}3.63 \\
(40)\end{array}$ & $\begin{array}{l}3.87 \\
(84)\end{array}$ & $\begin{array}{l}3.80 \\
(230)\end{array}$ \\
\hline $\begin{array}{l}\text { werkt } \\
\text { part- } \\
\text { time }\end{array}$ & $\begin{array}{l}3.69 \\
(26)\end{array}$ & $\begin{array}{l}3.77 \\
(35)\end{array}$ & $\begin{array}{l}3.56 \\
(75)\end{array}$ & $\begin{array}{l}\cdots \\
\text { (3) }\end{array}$ & $\begin{array}{l}4.55 \\
(20)\end{array}$ & $\begin{array}{l}3.74 \\
(159)\end{array}$ \\
\hline $\begin{array}{l}\text { stu- } \\
\text { deert }\end{array}$ & $\begin{array}{l}\ldots \\
(8)\end{array}$ & $\begin{array}{l}\ldots \\
(0)\end{array}$ & 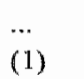 & $\begin{array}{l}4.50 \\
(10)\end{array}$ & $\begin{array}{l}3.66 \\
(118)\end{array}$ & $\begin{array}{l}3.72 \\
(137)\end{array}$ \\
\hline $\begin{array}{l}\text { huis- } \\
\text { houden }\end{array}$ & $\begin{array}{l}3.89 \\
(28)\end{array}$ & $\begin{array}{l}3.65 \\
(306)\end{array}$ & $\begin{array}{l}3.61 \\
(238)\end{array}$ & (1) & $\begin{array}{l}\ldots \\
(2)\end{array}$ & $\begin{array}{l}3.64 \\
(575)\end{array}$ \\
\hline Totaal & $\begin{array}{l}3.88 \\
(134)\end{array}$ & $\begin{array}{l}3.65 \\
(356)\end{array}$ & $\begin{array}{l}3.59 \\
(333)\end{array}$ & $\begin{array}{l}3.78 \\
(54)\end{array}$ & $\begin{array}{l}3.80 \\
(224)\end{array}$ & $\begin{array}{l}3.70 \\
(1101)\end{array}$ \\
\hline
\end{tabular}

\section{Commentaar}

Als we de randtotalen vergelijken met het gemiddelde woor de gehele groep (3.70) dan vinden we de hoogste score (3.88) voor getrouwde vrouwen zonder kinderen, voor thuiswonende kinderen (3.80) en vrouwen met een volledige baan (3.80). 
Huiswrouwen scoren onder het gemiddelde $(3.64)$.

De verschillen met de groepsgemiddelde zijn niet groot; het is niet zo dat een bepalde groep er met hoge scores 'uitspringt'.

Als we de binnenfrequenties van de tabel bekijken en even geen acht slaan op de cellen warin minder dan 10 personen vallen, dan vinden we de hoogste scores voor part-time werkende thuiswonende kinderen (4.55) en voor alleenstaanden die studeren (4.50). De laagste scores vinden we bij vrouwen met kinderen en een volledige werkkring (3.53), zij het dat voor deze laatste groep de verschillen met hun zusters-in-de-huishouding gering zijn (3.65 resp. 3.61).

De getallen vormen geen interpreteerbaar geheel; het is niet zo dat éen van de door ons geselecteerde groepen een consistent hoger klachtempatroon vertoont, ook niet als we deze ongewogen gemiddelden corrigeren voor een aantal in de worige paragrafen gevonden factoren, die in z'n algemeenheid van invloed zijn op iemands score op de ABV-N.

De voor 'leeftijd", "chronische ziekte', 'sociaal economische status', 'urbanisatie" en 'integratie' gecorrigeerde scores vindt men in tabel 6.11. Eerst laten we de ongewogen scores zien (de randtotalen van tabel 6.10) en vervolgens de scores zoals ze na het uitvoeren wan een multiple classificatieanalyse er uit zien. Bij deze laatste scores is rekening gehouden met de invloed van de bovengenoemde variabelen.

Tabel 6.11.: Ongewogen en gecorrigeerde ABV-N-scores woor vrouwen jonger dan 45 jaar, gehuwd of altijd ongehuwd geweest, naar samenlevingsverband respectievelijk soort werkzaamheden. (Multiple classificatie analyse) LSO 1977.

\begin{tabular}{|c|c|c|c|c|c|c|c|}
\hline \multirow[b]{2}{*}{$\begin{array}{l}\text { gezin } \\
\text { zonder } \\
\text { kinde- } \\
\text { ren }\end{array}$} & \multirow[b]{2}{*}{$\begin{array}{l}\text { gezin } \\
\text { jongste } \\
k \times 6 \text { jr. }\end{array}$} & \multicolumn{2}{|c|}{ Samenlevingsverband } & \multicolumn{4}{|c|}{ Soort werkzaamheden } \\
\hline & & $\begin{array}{l}\text { gezin alleen- } \\
\text { jongste staande } \\
\mathrm{k} .>6 \mathrm{jr} \text {. }\end{array}$ & $\begin{array}{l}\text { thuis- } \\
\text { wonend } \\
\text { kind }\end{array}$ & $\begin{array}{l}\text { werkt } \\
\text { full- } \\
\text { time }\end{array}$ & $\begin{array}{l}\text { werkt } \\
\text { part- } \\
\text { time }\end{array}$ & $\begin{array}{l}\text { stu- } \\
\text { deert }\end{array}$ & $\begin{array}{l}\text { huis- } \\
\text { houden }\end{array}$ \\
\hline
\end{tabular}

\begin{tabular}{|c|c|c|c|c|c|c|c|}
\hline $\begin{array}{l}\text { wogen } 3.88 \\
\text { scores }\end{array}$ & 3.65 & 3.59 & 3.78 & 3.80 & 3.80 & 3.74 & 3.72 \\
\hline
\end{tabular}

gecor-

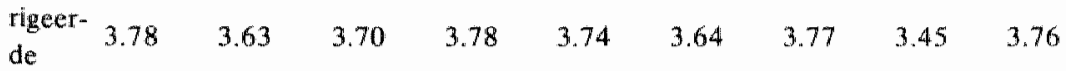

scores 


\section{Commentarar}

De weranderingen in de categorile 'soort bezigheden' zijn wat sterker dan in de categorie 'samenlevingsverband'. Met name de scores van scholieren en studenten zakken sterk als rekening gehouden wordt met de factoren die in het algemeen (althans volgens ons model) van invloed zijn op iemands score op de ABV-N. Het 'stuiwertje wisselen' van de scores voor wrouwen met een wolledige baan (was 3.80 wordt 3.64) en huisvrowwen (was 3.64 wordt 3.76 ) heeft te maken met de invloed van 'sociale status"; het hangt blijkbaar af van opleiding en het soort werk dat men doet of de factor "werk" van invloed is op iemands onwelbevinden.

Toch zijn de veranderingen gering (de effecten van beide variabelen 'soort bezigheden' en "samenlevingsverband" zijn niet significant) en mogen we aan de waargenomen verschillen weinig waarde hechten.

We moeten dan ook concluderen, dat de globale verschillen in positie en aktiviteitenpatroon van gehuwde of altijd ongehuwd geweest zijnde jongere vrouwen niet bepalend zijn voor de mate waarin zij spanningen vertonen.

Het is niet onwaarschijnlijk dat men wel werschillen zou vinden als men verder zou zoeken naar meer kwalitatieve factoren; de aard van de huwelijksrelatie of de relatie met de kinderen. Hierover zijn echter in het Leef Situatie Onderzoek geen vragen gesteld, zodat wij onze analyse met de constatering dat er ün ieder geval geen caregorische positionele bronnen van onwelbevinden te localiseren zijn, moeten besluiten.

\subsection{Samenvatting}

We zullen de samenvatting van de resultaten van hoofdstuk 6 zeer summier houden, omdat op de volgende pagina de samenvatting van het eerste deel in zijn totaliteit begint.

De resultaten van hoofdstuk 6 hebben betrekking op de vraag: welke factoren bepalen 'chronische ziekte', welke 'emotionele labiliteit' en wat is de relatie tussen 'chronische ziekte', 'emotionele labiliteit' en het uiten van lichamelijke klachten.

\section{Chromische ziekte}

Niet verrassend vonden wij dat leeftijd en (in minder sterke mate) geslacht en sociale status van invloed zijn op iemands gezondheidstoestand. Ouderen, wrouwen en personen uit de laagste status-categorie hebben een slechtere gezondheid dan jongeren, mannen en personen uit de hogere lagen van de matschappij. Bovendien vonden wij een nog slechtere gezondheid voor personen tussen 35 en 44 jaar uit de laagste status-categorie. Voor de andere variabelen in het model vonden wij geen verband. Weduwen, weduwnaars en gescheiden personen hebben (in tegenstelling tot wat men in de literatuur wel tegenkomt) geen slechtere gezondheid dan men op 'grond van hun leeftijd, geslacht en sociale status' zou verwachten. Dit geldt ook voor werklozen, ook zij zijn niet ongezonder dan men zou verwachten. 


\section{Emotionele labilitert}

Wij vonden dat de score op de ABV-N hoger is,

- naarmate iemand jonger is

- naarmate iemand lager op de maatschappelijke ladder staat

- voor vrouwen dan voor mannen

- voor gescheiden personen dan voor verweduwde, gehuwde of altijd ongehuwd geweest zijnde personen

- voor weduwen en weduwnaars dan voor gehuwde of altijd ongehuwd geweest zijnde personen

- voor werklozen en arbeidsongeschikten dan voor werkenden, studerenden, gepensioneerden of huisvrouwen

- voor chronisch zieken dan voor gezonden

- naarmate iemands woonplaats groter is

- naarmate iemand beter is geïntegreerd in een normatief systeem (kerkelijk en kerks is) dan wel in zijn directe omgeving (in butrt woont met 'mensen zoals wij" en contacten met de buren rapporteert).

Alles bij elkaar echter verklaart deze set van variabelen slechts een gering deel van de variantie in de $\mathrm{ABV}-\mathrm{N}$-scores; ons model is bij lange na geen volledige opsomming van situaties die tot onwelbevinden aanleiding geven, of wellicht is het eerder zo dat het grootste deel van de variantie persoonsgebonden is.

Niettemin zijn de verbanden die we vinden van wetenschappelijk en matschappelijk belang; nader onderzoek zal moeten volgen.

\section{Lichamelijke klachten}

Als we de resultaten van de eerste fase van onze analyse gebruiken voon het verklaren van iemands score op de VOEG, dan zien we dat 'slechte gezondheid" en 'emotionelle labiliteit' beide iemands score op een lijst met lichamelijke klachten beïnvloeden. Tot op zekere hoogte moet er worden bij gezegd, want ook hier is de proportie verklaarde variantie niet hoog.

Als we één voor één de onafhankelijke variabelen in het model in de analyse brengen om te zien of ze nog een extra invloed op de klachtenscores hebben, dan zien we dat jongeren, vrouwen en niet-verweduwde of gescheiden personen (dus gehuwde of altijd ongehuwd geweest zijnde) meer lichamelijke klachten uiten, dan we op grond van het gegeven dat ze chronisch ziek zijn of een hogere score op de $A B V-N$ hebben zouden verwachten.

We hebben daarom voor de groep vrouwen jonger dan 45 jaar, gehuwd of nooit gehuwd geweest nog eens verder gezocht naar situaties waarin men klachten uit. Wij vonden echter geen interpreteerbare verschillen voor alle combinaties van het soort bezigheden (werk, studie, huishouden) met het soort samenlevingsverband (gezin zonder kinderen, gezin met (heel) jonge kinderen, gezin met schoolgaande kinderen, alleenstaande of zelf thuiswonende kinderen). Wij moesten het hoofdstuk eindigen met de conclusie dat er althans geen categorische verschillen zijn 
aangetroffen; huisvrouwen zijn niet categorisch ongelukkiger dan werkende vrouwen - alleenstaanden zijn niet categorisch ongelukkiger dan gehuwden - maar dat ook hier geldt dat nader onderzoek geboden is. 


\section{7}

\section{Samenvatting van deel I}

Deze studie zou niet in deze vorm zijn ontstaan als er onderzoeksmateriaal bestond dat enerzijds een groot aantal kemmerken van individuen en gezinnen, van invloed op het ontstaan van een behoefte alan diensten van de huisarts zou bevatten en waarin anderzijds gegevens over de persoon en werkwijze van de huisarts en van de organisatie van diens praktijk (de aanbodzijde in dit deel van de gezondheidszorg) niet zouden ontbreken. In dat geval namelijk, zouden we de (gerealiseerde) vraag naar diensten van de huisarts op bevredigende wijze kumnen vaststellen.

Om vraag- en aanbodfactoren op een verantwoorde wijze aan elkaar te kunnen koppelen zouden bovengenoemde gegevens per huisartspraktijk moeten worden verzameld, zij het dat de summiere informatie die de huisarts over de personen en gezinnen uit zijn patiëntenbestand in zijn administratie vermeldt, drastisch uitgebreid zou moeten worden met gegevens die men aan de ingeschreven patiënten zou moeten vragen.

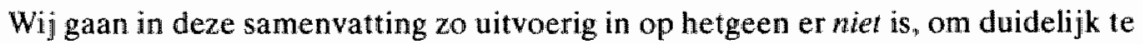
maken welke beperkingen aan het hier beschreven onderzoek kleven en om begrij* pelijk te maken waarom wij in bepaalde zaken zoveel belang stellen. Als men uitgaat en uit moet gaan van bestaande gegevens, dan treft men enterzijds zogenaamde praktijkstudies aan, studies waar huisartsen systematisch bijhouden wat er zoal aan hun loket komt en wat zij daarmee doen. Dit betreft meestal studies over één of enkele praktijken; waarin aan de 'vraagzijde' (kenmerken wan de personen en gezinnen die tezamen de praktijk vormen) meestal slechts summiere gegevens bekend zijn. Dergelijke studies zijn vanwege de uiterst tijdrovende en kostbare opzet slechts zelden op grotere schaal uitgevoerd.

De tegenhanger van deze praktijkstudies wordt gevormd door zogenaamde "bevolkingsenquêtes", meestal groot opgezette onderzoekingen waarin mensen bijvoorbeeld gevraagd wordt hoe vaak ze in een bepaalde periode bij de huisarts zijn 
geweest en waarin dit gegeven in verband gebracht wordt met een scala van, eveneens gevraagde, achtergrondkenmerken en opvattingen. Kenmerken over de aaribodzijde, de hulpverleners en instellingen ontbreken echter meestal. Dit type onderzoek is minder schaars; we zijn dan ook begonnen met het stellen van de vraag in welke mate deze bevolkingsenquêtes bruikbaar zijn voor het vaststellen van de vraag naar diensten van de huisarts.

Daartoe hebben we eerst bekeken of de 'bevolking' in bevolkingsenquetes overeen komt met de 'bevolking' van een huisartspraktijk. Het antwoord hierop is zelden positief, omdat om allerlei praktische redenen (aparte vragenlijsten woor kinderen bijwoorbeeld) meestal alleen personen van 15,18 of 20 jaar en ouder worden ondervraagd en soms ook aan de bovenzijde een leeftijdsgrens wordt gesteld.

Ten tweede hebben we bekeken hoe 'doktersbezoek" gemeten is en geconstateerd dat de periode warover mensen gevraagd worden hun bezoek aan de huisarts te rapporteren warieert van 2 weken tot 12 maanden en dat, als regel, geen onderscheid is gemaakt tussen contacten op initiatief van de patiënt en contactern op initiatief van de huisarts. Dit laatste onderscheid is van groot belang omdat een dienstverlener in het algemeen een gedeelte van de vraag naar zijn diensten zelf kan bepalen door cliënten al dan niet 'terug te bestellen'.

Na te hebben vastgesteld, dat als regel zelden iets gevraagd wordt over factoren aan de aanbodzijde (een uitzondering hierop vormt de nieuwste gezondheidsenquête wan het CBS, waarvan de resultaten binnenkort beschikbaar komen) zoals het soort praktijk, de afstand tot de praktijk, de drukte op het spreekuur etc, hebben we een aantal studies vergeleken op hetgeen ze aan de vraagzijde hebben gemeten. Hierin zijn natuurlijk grote verschillen aan te treffen, omdat iedere onderzoeker zo zijn eigen belangstelling heeft. Eén ding hebben al de enquêtes gemeen: er wordt in ieder geval een poging gedaan om de (beleving van) de gezondheidstoestand van de respondent vast te stellen. Soms door hem alleen te vragen hoe hij zich in zijn algemeenheid voelt; meestal door een lijst met aandoeningen of klachten voor te leggen waarop hij kan aanstrepen waar hij zoal last van heeft.

Bekijkt men de resultaten van al deze studies, dan verdwijnt plotsklaps de grote diversiteit. Iedere onderzoeker vindt, hoe elegant of interessant de opzet van zijn onderzoek ook moge zijn geweest, dat mensen naar de dokter gaan als ze klachten hebben over hun gezondheid.

De reacties op deze lichtelijk banale constatering zijn velerlei. De ene groep maakt van deze constatering gebruik om er op te wijzen dat ${ }_{4}$ nu de behoefte aan gezondheidszorg kennelijk de vraag ernaar vrijwel volledig bepaalt, de onrechtvaardigheden en ongelijkheden in de gezondheidszorg zijn opgeheven. Niet het inkomen van de gebruiker maar de toestand van zijn gezondheid is de belangrijkste voorspeller van het gebruik. Mensen krijgen blijkbaar de zorg die ze nodig hebben.

Een andere groep probeert hardnekkig het effect van de invloed van 'gezondheidstoestand" ongedaan te maken door te kijken of sommige factoren niet toch, nadat door middel van partiële correlatierekening de invloed van 'gezondheidstoestand' is 
uitgeschakeld, het aantal contacten met de huisarts beinvloeden. Veel levert zo'n benadering niet op; soms blijkt een bepaalde groep (in het onderzoek van Nuyens e.a. bijwoorbeeld oudere vrouwen uit verstedelijkte gebieden) inderdaad de huisarts te consulteren zonder dat men klachten over de gezondheid heeft, maar erg goed te interpreteren zijn deze resultaten niet, laat staan dat er wetenschappelijk of maatschappelijk belangwekkende conclusies aan te verbinden zijn.

Onze redenering is daarom als volgt geweest: als het zo evident is, dat mensen als regel niet naar de huisarts gaan als ze geen klachten over hun gezondheid hebben, dlan moeten we eerst proberen te verklaren welke factoren van invloed zijn op het hebben of uiten van lichamelijke klachten en pas in een volgend stadium proberen de vraag naar diensten van de huisarts te woorspellen.

\section{Wat betekent het meten van lichamelijke klachten}

Met deze vraag belanden we midden in een discussie over de kwestie wat men nu eigenlijk meet als men mensen vraagt of ze last hebben van allerlei symptomen. Of eigenlijk is "discussie" niet het goede woord; er zijn verschillende groepen onderzoekers die hierover een van elkaar verschillende mening hebben, die zij niet aan elkaar toetsen, een uitzondering daargelaten. Sommigen menen dat men met een lijst symptomen en aandoeningen 'gezondheid' meet; anderen daarentegen zijn van oordeel dat men op deze wijze 'stress' kan meten. Tenslotte is er een hele groep, vooral psychologisch geschoolde onderzoekers, die ervan uitgaan dat iemands score op een lijst met lichamelijke klachten een maat is voor diens neurotische labiliteit.

Onze conclusie, na bestudering en bespreking van de literatuur is, dat iemands score op een lijst met lichamelijke klachten zowel indicatie kan zijn voor iemands slechte gezondheid als voor iemands neurotische labiliteit. "Stress" valt af, omdat men name 'langdurige niet intensieve stress' wel heel ver van het biologische stressbegrip afstaat.

Nu is de constatering dat een lijst met lichamelijke klachten zowel slechte gezondheid meet als neurotische labiliteit niet baanbrekend te noemen; de samensteller van de belangrijkste vragenlijst op dit gebied heeft hier al duidelijk op gewezen. Iets anders is, wat men nu verder moet ondernemen, na dit te hebben geconstateerd. Wij hebben de beide componenten afzonderlijk in een model willen verklaren. Dit kan alleen als we naast een lijst met lichamelijke klachten beschikken over een indicator van 'gezondheidstoestand" die zo min mogelijk gecontamineerd is met het uiten van symptoomklachten en als we neurotische labiliteit ook onafhankelijk van de lijst met lichamelijke klachten zouden kunnen vaststellen.

In het door het Centraal Bureau voor de Statistiek in 1977 gehouden Leef Situatie Onderzoek (LSO 77) waarop we de in dit deel beschreven analyses hebben uitgevoerd, treffen we deze indicatoren inderdaad aan.

Enerzijds bevat dit onderzoek een lijst met lichamelijke symptomen: een verkorte versie van de VOEG, de Vragenlijst voor Onderzoek van de Ervaren Gezondheidstoestand; anderzijds moeten mensen aangeven of ze lijden aan 26 met name 
omschreven categorieèn wan min of meer ernstig te noemen aandoeningen. Bovendien is in het onderzoek opgenomen een maat voor neurotische labiliteit die gebaseerd is op niet-lichamelijke klachten (de ABV-N). In schemavorm proberen we het volgende model te construeren.

Figuur 7.1. Schematisch model voor het verklaren van doktersbezoek in vragenlijst onderzoek.

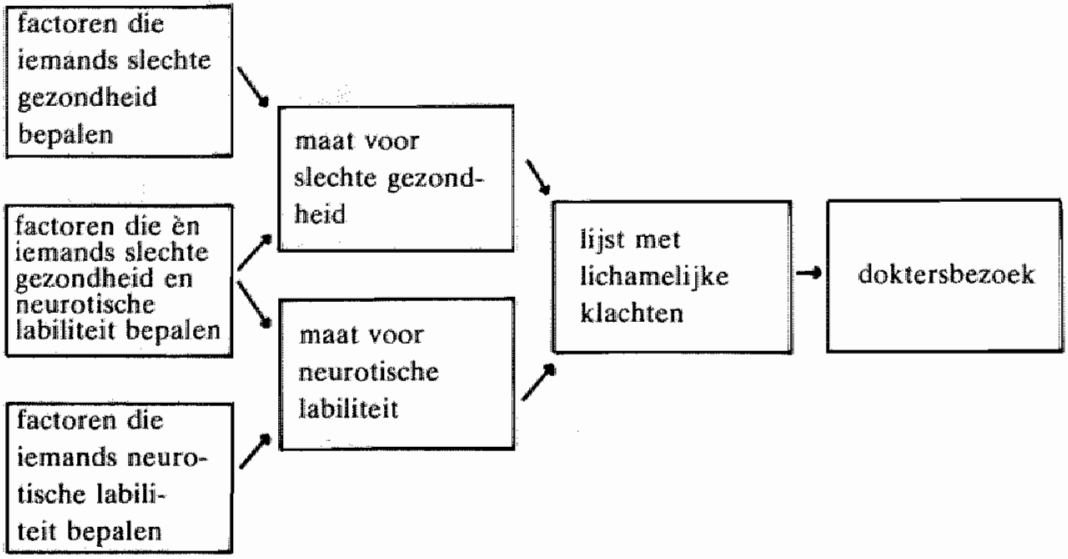

Op dit punt in ons betoog staan we voor de taak in de literatuur op zoek te gaan naar factoren die van invloed zijn op iemands slechte gezondheid dan wel op iemands neurotische labiliteit. Een dergelijk onderzoek wordt bemoeilijkt omdat doorgaans de hierboven onderscheiden componenten niet van elkaar gescheiden zijn "zodat ook de invloed van een bepaalde variabele op de ene dan wel de andere component niet goed is vast te stellen. Bovendien wordt 'neurotische labiliteit' in de kring van psychologen als persoonlijkheidskenmerk beschouwd, hetgeen tot gevolg heeft dat men niet verder zoekt naar factoren die op hun beurt dit kenmerk weer beinvloeden. We zullen in deze samenvatting onze bevindingen uit de literatuur en uit de alledaagse ervaring (men behoeft per slot van rekening niet gestudeerd te hebben om wast te stellen dat "leeftijd' van invloed is op iemands gezondheid) direct laten volger door de resultaten wan onze analyses.

\section{Gezondheidstoestand}

Zoals gezegd staat het buiten kijf dat leeftijd gezondheidstoestand sterk beïnvloedt. Het zou vreemd zijn als we iets anders vonden; de resultaten laten ook een sterk verband zien.

Hoewel de levensverwachting van vrouwen aanzienlijk hoger is dan die wan mannen en men daaruit de conclusie zou kunnen trekken dat vrouwen 'gezonder' zijn dan 
mannen, vindt men toch bij vrouwen vanaf de vruchtbare leeftijd meer aandoenin. gen van min of meer ernstige aard dan bij mannen. Niet zo ernstig dat ze er aan dood gaan (vrouwen genieten mogelijk een zekere hormonale bescherming tegen aderverkalking en bovendien gaan ze minder vaak dood aan aandoeningen die duidelijk gerelateerd zijn aan een meer risico's omvattende leefwijze) maar ernstig genoeg om te verwachten dat in dit onderzoek mannen minder vaak een chronische aandoening opgeven dan vrouwen. De resultaten zijn conform deze verwachting. Wat betreft sociaal economische staus kan men uit de literatuur afleiden dat mensen uit de hoogste statuscategorie minder door ernstige ziekten worden getroffen en een gunstiger levensverwachting hebben dan mensen die op de lagere sporten van de maatschappelijke ladder staan. Er is hier sprake van een zekere wisselwerking; een handicap van jongs-af-aan kan iemand behoorlijk remmen bij het bestijgen wan de maatschappelijke ladder of zelfs veroorzaken dat het begrip 'maatschappelijke ladder' buiten het bevattingsvermogen blijft, maar in een met 'vangmetten' uitgerust stelsel van sociale verzekering betekent een ernstige ziekte op latere leeftijd nauwelijks meer een daling in social economische status. Onze onderzoeksresultaten (zie pag. 65) bevestigen deze verwachting, zij het dat wij tevens vinden dat personen uit de laagste statuscategorie van 35-44 jaar een nog slechtere gezondheid hebben dan men op grond van een lineaire combinatie (zoals dat in modeltermen heet; gewogen 'optelling' zouden we in normaal Nederlands zeggen) wan hun leeftijd en status zou verwachten. Dit geldt voor mannen èn vrouwen, hetgeen betekent dat niet alleen arbeidsomstandigheden verband houden met dit verschil. De kans op een chronische aandoening is volgens ons model voor vrouwen van 60 jaar uit de laagste sociale klasse ongeveer $50 \%$; voor mannen van 30 uit de hoogste statuscategorie op deze wijze berekend $15 \%$.

Geen verband met 'slechte gezondheid' vinden wij woor iemands burgerlijke staat. Gescheiden personen, weduwen of weduwnaars zijn niet 'ongezonder' dan men op grond van een combinatie van leeftijd, geslacht en status zou verwachten; alle (interessante) literatuur over de beschermende functie van huwelijk en gezin ten spijt.

Ook personen die werkloos zijn, hebben niet een chronisch slechtere gezondheid dan zij die werken, studeren of een huishouden drijwen. Was dat wel het geval, dam zouden ze waarschijnlijk hun werk via de Wet op de Arbeidsongeschiktheid hebben verlaten.

\section{Emotionele labiliteit}

Factoren die van invloed zijn op iemands emotionele labiliteit zijn moeilijk uit de literatuur af te leiden. We komen dan terecht bij onderzoekers die de verspreiding van symptomen van psychische stoornissen als onderwerp van studie hebben gekozen. Bij de interpretatie van hun resultaten moeten we echter bedacht zijn op mogelijke verstoringen doordat zij (ongewild) ook gezondheidstoestand hebben gemeter. 
Wè zullen eerst dezelfde variabelen die we bij "gezondheidstoestand" hebben besproken, de revue laten passeren.

De neiging om te klagen op uitnodiging, zoals de score op een klachtenlijst wel wordt geinterpreteerd, is waarschijnlijk generatie-gebonden. De oudere generatie is wat dat betreft wat 'flinker" of "geremder' dan de jongere. Wij verwachtten (en vonden) een negatief verband tussen leeftijd en klachtenscore. Dat is een belangwekkend resultaat, want als men even ons model voor ogen haalt, dan zien we dat 'leeftijd' positief samen'hangt met 'slechte gezondheid' en negatief met 'emotionele labiliteit'. Tezamen geteld betekent dit dat we soms wel en soms niet een verband tussen leeftijd en het uiten van lichamelijke klachten (de volgende stap in ons model) kunnen verwachten, hetgeen verklaart waarom sommige onderzoekers (tot hun verbazing) geen relatie tussen leeftijd en lichamelijke klachten vonden, terwijl deze klachten geacht werden een maat voor de toestand van iemands gezondheid te zijn.

Voor de factor geslacht liggen de zaken anders. Vrouwen zijn meer geneigd in te gaan op een uitnodiging tot klagen en hebben (zoals we hierboven hebben gesteld) ook een grotere kans op een clrronische aandoening. En meer klagen èn een sllechtere gezondheid betekent een hoge score op een lijst met lichamelijke klachten, maar ook dat het effect van beide componenten afzonderlijk moeilijk vast te stellen is. Dit heeft tot gevolg dat of de lichamelijke of de geestelijke gezondheid van vrowwen wordt onderschat, omdat onderzoekers zich zelden of nooit van de contaminatie van deze twee aspecten rekenschap geven.

Voor de invloed van 'sociaal economische status' geldt ditzelfde probleem. Het wordt uit de literatuur niet duidelijk of 'slecthte gezondheid' dan wel, 'emotionele labiliteit' dan wel beide een verklaring vormen voor de hogere klachtenscores van personen uit de laagste statuscategorieën. Onderzoekers die aantonen dat handarbeiders er psychisch slechter aan toe zijn, vergeten rekening te houden met de gezondheidstoestand en omgekeerd. De resultaten in de literatuur zijn zo onduidelijk, dat we geen verwachting durfden formuleren. We pinden dat mensen uit de laagste statuscategorie meer klachten hebben, ook als we rekening houden met hun slechtere gezondheid (resultaten pag. 67 en 69).

Wat betreft 'burgerlijke staat.' troffen we een interessante discussie aan over de vraag of het nu juist gehuwde vrouwen of vrouwen zonder partner zouden zijin die de meeste symptomen van onwelbevinden zouden vertonen. Wij vonden de argumenten voor de bewering dat het juist de niet meer gehuwde personen zouden zijn het meest steekhoudend. Onze bevindingen zijn conform deze verwachtingen. Gescheiden personen hebben de meeste klachten, gevolgd door weduwen en weduwnars. Deze beide groepen scoren hoger dan gehuwde of altijd ongehuwd geweest zijnde personen.

Wij beschouwen het verlies van een partner door overlijden of scheiding als een 'suboptimale' situatie. Dat wil zeggen een situatie warin, gegeven de samenstelling van de maatschappij, weinig verandering kan komen. De huwelijksmarkt voor oudere 
vrouwen is door de oversterfte van mannen ronduit slecht te noemen; de mogelijkheden voor jonge of oudere werklozen om weer werk te vinden, eveneens. Een chronische slechte gezondheid maakt het leven extra belastend. Het werk wan de Groningse socioloog Ormel geeft ons stof voor deze stellingen, die ook in ons materiaal bevestigd worden. We vermeldden al hogere scores voor gescheiden en verweduwde personen; maar ook werklozen, arbeidsongeschikten en chronisch zieken klagen meer; zijn er geestelijk slechter aan toe, zoals uit de resultaten van ons onderzoek blijkt.

Als laatste groep factoren die van invloed zijn op 'emotionele labiliteit' hebben we enkele indicatoren voor (normatieve) integratie opgenomen. Uit het werk van Drop (wier onderzoek op een lange op Durkheim terug te voeren sociologische traditie stoelt) wordt duidelijk dat integratie in een normatief systeem onder meer van invloed is op het vòrkomen van psychische stoornissen en van de vormen waarin afwijkend, normoverschrijdend gedrag zich manifesteert. Wij vinden dat personen die zich onkerkelijk noemen meer klachten hebben dan personen die kerkelijk zijn en de kerk ook bezoeken. We vinden bovendien dat integratie in de woonomgeving samengaat met minder klachten. Tenslotte vinden we, dat personen uit grotere steden meer klagen dan personen uit kleinere plaatsen.

Dit resultaat valt goed te interpreteren in de integratietheorie. Als het aantal inwoners toeneemt neemt de sociale controle af en het aantal gedragsalternatieven toe. Dit laatste beïnvloedt vooral het zogenaamde "vluchtgedrag" waarvan psychische stoornissen in het algemeen en emotionele labiliteit in het bijzonder een uiting is. Tot zover de resultaten van het onderdeel 'emotionele labiliteit'. Een ding hebben we nog niet vermeld; hoewel de bovengenoemde bevindingen niet van relevantie zijn ontbloot, verklaren we in z'n totaliteit maar een zeer gering deel van het verschijnsel 'emotionele labiliteit'. Verreweg het grootste gedeelte blijft onverklaard.

Dit wordt gedeeltelijk veroorzaakt door onze werkwijze; wij hebben er angstvallig voor gewaakt om in het model variabelen op te nemen die betrekking hebben op (on)tevredenheid, algemene gevoelens van onwelbevinden en machteloosheid; zaken waarvan een samenhang met psychische en lichamelijke klachten bij voorbaat gegeven is.

Desalniettemin kunnen we concluderen dat de in het model opgenomen siluaties waarschijnlijk slechts een klein deel vormen van de situaties waarin mensen tot klagen komen; nader onderzoek díent hier plaats te vinden.

De (gedeeltelijke) verklaring van gezondheidstoestand en emotionele labiliteit vormt de eerste fase van ons model.

In de tweede fase proberen we iemands score op een lijst met lichamelijke klachten. in dit geval de VOEG (de Vragenlijst voor Onderzoek naar de Ervaren Gezondheidstoestand), te verklaren uit "slechte gezondheid" en 'emotionele labiliteit". 


\section{Lichamelike klachten}

lemands score op een lijst met lichamelijke kJachten blijkt inderdaad uit twee componenten te bestaan. Enerzijds meet de lijst 'slechte gezondheid', anderzijds "emotionele labiliteit". Dat blijkt eveneens uit een factoranalyse die we op de door ons gebruikte verkorte versie van deze klachtenlijst hebben los gelaten. Naast een factor 'malaise', zijn drie lichamelijke factoren te onderscheiden: 'maag/spijsvertering'; 'thorax' (ademhaling/hart); en 'bewegingsapparaat' (rugpijn, spierpijn). Onze mat voor psychische klachten (de ABV-N) hangt het sterkst samen met de factor 'malaise-klachten" (moe, suf, lusteloos). Als we kijken welke van de oorspronkelijke onafhankelijke variabelen in ons model nog een extra verband vertonen (dat wil zeggen buiten hun invloed op de variabele 'chronisch ziek' of 'emotionele labiliteit") dan zien we dat 'jongeren", 'vrouwen" en nier gescheiden of verweduwde' personen meer lichamelijke klachten hebber dan men op grond van hun gezondheidstoestand en emotionele labiliteit zou verwachten. Blijkbaar hebben we voor die groep(en) te weinig probleemsituaties en/of belastende omstandigheden onderscheiden. Wij hebben daarom in een laatste paragraaf nog een poging gewaagd om voor jongere (jonger dan $45 \mathrm{jr}$.) gehuwde of altijd ongehuwd geweest zijndle vrouwen probleemsituaties op het spoor te komen. Bekeken is hoe de klachtenscores variëren bij combinaties van burgerlijke staat, gezinsfase en bezigheden, malar geen van deze combinaties levert significant meer klachten op dan een andere. Noch 'werk', noch 'huishouden', noch 'wel of geen kinderen', noch de leeftijd van de kinderen zijn als zodanig en in combinatie bepalend voor de hoeveelheid psychische klachten van jongere, gehuwde of altijd ongehuwd geweest zijnde vrouwen.

We hebben in dit onderzoek niet kunnen ontdekken waar de problemen wel zitten, maar ook de constatering dat binnen de groep vrouwen van 15-45 jaar (gehuwd of altijd ongehuwd geweest) bepaalde subgroepen niet categorisch worden belast, is onzes inziens niet van belang ontbloot. 


\section{Deel II: Doktersbezoek}





\section{Inleiding}

Na een kleine 100 pagina's tekst over het onderwerp 'klachten', zou het voor de hand liggen om de rest van ons betoog te besteden aan het beschrijven van het verband tussen klachten en doktersbezoek en wel in de vorm van een verdere analyse van de in deel I gebruikte gegevens uit het Leef Situatie Onderzoek 1977. Wij zouden dan echter voorbijgaan aan de door ons in hoofdstuk 3 geformuleerde kritiek op het analyseren van 'medische consumptie' met behulp van zogenaamde bevolkingsstudies.

Deze bevolkingsstudies bevatten vele kenmerken van de consumenten, waardoor onderzoekers in staat gesteld worden om tamelijk genuanceerde modellen op te stellen voor de vraagzijde van de gezondheidszorg (denk aan het in deel I geformuleerde model ter verklaring van lichamelijke klachten), maar ze zijn meestal zeer spaarzaam bedeeld met kenmerken van de aanbodzijde. Hivermee hangt samen dat in deze studies de vraag naar diensten van de huisartsen meestal niet goed is geïndiceerd. Zelfs in meer recente publicaties (Rutten, 1978, hst 3 en 4, Nuyens e.a., 1979, deel 1. F, p. $15 \mathrm{ev,} \mathrm{Van} \mathrm{der} \mathrm{Gaag} \mathrm{1978,} \mathrm{p.} \mathrm{32)} \mathrm{waarin} \mathrm{op} \mathrm{theoretische}$ gronden een onderscheid wordt gemaakt tussen contacten op initiatief wan de patiënt en contacten op initiatief van de huisarts, speelt het onderscheid tussen typische vraagaspecten (contacten op initiatief patiënt) en mede door aanbodfactoren beïnvloede contacten op initiatief van de arts geen rol in de analyse.' In het reeds genoemde Leef Situatie Onderzoek is geen onderscheid te maken in de verschillende soorten doktersbezoek en ontbreekt het aan rechtstreeks gemeten aanbodkenmerken. Zouden we 'zomaar' dit materiaal gaan analyseren dan zou dit leiden tot een overschatting wan kenmerken van patiënten die zowel eerste als terugbestelcontacten in dezelfde richting beïnvloeden en tot een verwaarlozing van de factoren die aan de aanbodzijde de consultfrequenties bepalen. Aan laatstgenoemde factoren wordt toch al weinig aandacht besteed, omdat het onderscheid 
tussen 'eerste' en 'terugbestelcontacten' het best gemaakt kan worden in zogenaamde "prakkijkstudies" die betrekking hebben op één of meer huisartsenpraktijken en war men per consult aard en herkomst kan noteren.

Aangezien dit soort studies in het algemeen slechts enkele praktijken omvat, valt er ook weinig aan aanbodkenmerken te analyseren. ${ }^{2,3}$ Ten hoogste beperkt men zich (zoals Rutten, 1978, wan der Gaag, 1978 en Van der Gaag en Van de Ven, 1978) tot het opnemen van een nominale variabele voor de verschillende huisartsen.

Het ontbreken van geschikt materiaal hoeft ons echter niet te weerhouden van het formuleren wan verwachtingen over verbanden die we zouden aantreffen als we wèl beschikten over bruikbare gegevens (hoofdstuk 9).

Bovendien kunnen we proberen om te woorspellen welke relaties we aantreffen in het geval dat in het doktersbezoek de invloed van patiënt en huisarts niet meer van elkaar te onderscheiden zijn. Het spreekt vanzelf dat dergelijke voorspellingen alleen met de grootste voorzichtigheid kunnen worden gedaan. Wij zullen uiteindelijk (in hoofdstuk 11), na het formuleren van de verwachte relaties tussen klachten, overige vraagaspecten, aanbodfactoren enerzijds en de verschillende vormen van doktersbezoek anderzijds, proberen het Leefsituatie-materiaal nader te analyseren. Dit zal een noodzakelijkerwijs ruwe analyse worden, waarvan het de vraag is of met name de werking van aanbodfactoren, die men vooral in praktijkstudies moet bestuderen, aangetoond kan worden. Om toch iets over de werking van aanbodfactoren te kunnen zeggen, zullen we in hoofdstuk 10 eerst de resultaten beschrijwen van een analyse van gegevens uit de Engelse gezondheidszorg; namelijk het verband tussen praktijkvorm, praktijkgrootte, praktijklocatie en het aantal contacten op initiatief van de patiënt, het aantal contacten op initiatief van de huisarts en het aantal verwijzingen, gegeven de verdeling van de praktijkbevolking nałr leeftijd en geslacht.

Als we met behulp van dit materiaal meer inzicht kunnen krijgen in de werking van aanbodfactoren, helpt dit ons om, ook al hebben we dan niet de beschikking over materiaal waarin zowel aan de vraag - als de aanbodzijde goede operationaliseringen aanwezig zijn, voorspellingen zo exact mogelijk te formuleren.

Deel II is als volgt opgebouwd:

In hoofdstuk 9 formuleren wij verwachtingen over de relatie tussen klachten en doktersbezoek en vullen dit aan met voorspellingen over te verwachten relaties buiten het klachtenmodel, zoals doktersbezoek zonder klachten en de invloed van de uitgebreidheid van het pakket verzekeringen tegen ziektekosten en inkomstenderving en aanbodfactoren. Een groot aantal van deze verwachtingen kan met behulp van het huidige beschikbare materiaal niet of siechts ten dele worden getoetst.

In hoofdstuk $10 \mathrm{en} 11$ worden resultaten gepresenteerd; in hoofdstuk 10 wolgt eerst cen weergave van een beperkte aambodanalyse met behulp van gegevens uit de Engelse gezondheidszorg. Vervolgens bezien we in het materiaal van het Leef 
Situatie Onderzoek de relatie tussen klachten en doktersbezoek op individueel niveau gegeven de structuur van de gezondheidszorg ter plaatse.

In hoofdstuk 12 vatten we de resultaten van deel II samen en tenslotte wijden we een laatste hoofdstuk aan het bespreken van de resultaten van deel 1 en deel II tezamen. 


\section{Factoren van invloed op de vraag naar doktersbezoek}

Het logische vervolg van ons in deel I geformuleerde model ter verklaring van iemands score op een lijst met lichamelijke klachten is het beschrijven van de invloed van de verschillendle componenten van het model op de vraag naar de verschillende soorten diensten van de huisarts. De factoren die in het model worden ornschreven zijn echter niet als enige van invloed op de vraag naar doktersbezoek. Het model is alleen geformuleerd voor individuen die min of meer zelfstandig beslissingen kunnen nemen; het onderzoeksmateriaal bevat geen gegevens over klachten en doktersbezoek van personen jonger dan 1.5 jaar.

Ook valt alle vraag naar diensten van de huisarts waaraan geen klachten ten grondsllag liggen, buiten het model. Voor bijvoorbeeld anticonceptiemiddelen gebruikende vrouwen wormt deze vraag een substantieel deel van hun medische consumptie. Bovendien is het niet uitgesloten dat, gegeven de klachten, deze in bepaalde omstandigheden tot meer doktersbezoek zullen leiden dan in andere. Wij denken hierbij aan de 'mogelijkheids'-variabelen (vormen van verzekering tegen ziektekosten, verzekering tegen inkomstenderving, kostbaarheid van iemands tijd) uit de modellen van Andersen (1968, 1975) ${ }^{4}$ In ons model beschouwen we ook dit als vraagfactoren. Tenslotte zijn we van mening dat doktersbezoek, als functie van vraag èn aanbod, niet kan worden verklaard zonder bestudering van aanbodfactoren in de huisartspraktijk.

\subsection{Het klachtenmodel}

Zoals we in het eerste deel hebben laten zien bestaat het klachtenmodel uit twee componenten: "slechte gezondheid" en "emotionele labiliteit'. Kan men een verschillende invloed verwachten van deze twee componenten op eerste- en terugbe- 
stelcontacten? Wat 'slechte gezondheid" betreft hangt dat een beetje af van de omschrijving van 'eerste' contact of 'terugbestelcontact'. Als men bijvoorbeeld alle contrôles van een chronische aandoening beschou wt als terugbestelcontact, dan kan een ziekteperiode meerdere jaren omvatten. Echter ook een chronische aandoening kan in intensiteit fluctueren; crises kunnen optreden, maar ook kan een chronische aandoening een extra risicofactor zijn bij het optreden van bijvoorbeeld alledaagse infectieziekten.

Wij verwachten een posititieve invloed wan deze component op de vraag naat eerste contacten en een nog sterker positieve invloed op de vraag naar terugbestelcontacten (tenzij - maar nu lopen we vooruit op de volgende paragrafen - een groot aanbod van tweedelijnsvoorzieningen (aantal specialisten en ziekenhuisbedden en afstand tot ziekenhuis) een belangrijk deel van deze patiënten naar zich toetrekt). Gezien de ernst van de problematiek zullen aanbodfactoren in de huisartspraktijk noch op eerste contacten noch op terugbestelcontacten van merkbare invloed zijn (wellicht met uitzondering van terugbestelcontacten in situaties met een groot aanbod aan specialistische voorzieningen).

Als men "emotionele labiliteit" opvat als de neiging tot klagen op uitnodiging dan ligt een relatie met de wijze waarop de huisarts zijn patiënten terugbestelt voor de hand. Aangezien, in tegenstelling tot de hierwoor beschreven factor, de medische noodzaak tot behandeling minder duidelijk is, zullen deze terugbestelcontacten gevoeliger zijn voor aanbodfactoren in de huisartspraktijk (wachttijden, spreekuurdrukte) en zal de mogelijkheid tot verwijzen sterker interfereren met de kenmerken van de huisartspraktijk. De speelruimte voor alternatieven is groter dan bij de chronisch. zieken. Dat wil zeggen dat met name de terugbestelcontacten gevoeliger zijn voor de tijd die de huisarts aan zijn patiënten wil en kan besteden. Is die tijd er niet, dan zal de huisarts geneigd zijn te verwijzen. Ontbreekt die mogelijkheid, dan zal een verminderde neiging tot terugbestellen het gevolg zijn, hetgeen weer invloed zal hebben op het aantal eerste contacten.

Voor beide componenten geldt dat de invloed op de vraag naar eerste- en terugbestelcontacten in dezelfde richting wordt gedacht, maar dat met name het met de factor "emotionele labiliteit" te verwachten aantal terugbestelcontacten gevoeliger is voor externe invloeden (aanbodfactoren in de huisartspraktijk en de mogelijkheden die de huisarts ter beschikking staan om zijn clienten tijdelijk elders in de gezondheidszorg onder te brengen). Empirische resultaten die deze verwachting ondersteunen zijn er niet of nauwelijks. Tessler, Mechanic en Dimond (1976) doen verslag van een onderzoek binnen én groepspraktijk, waarin zij 'psychological distress' (een maat samengesteld uit 5 componenten, zoals onprettige gevoelens, zorgen, neuroticisme), 'chronische ziektes' (gemeten op een analoge wijze als in het L.S.O.) tesamen met enkele achtergrondkenmerken van de patiënten in verband brachten met bezoek aan de groepspraktijk. (Retrospectief en prospectief). Naast het totaal aantal contacten hebben zij ook 'symptom based first contacts' onderscheiden. In hun uiteindelijke regressievergelijking (anders dan in ons geval, niet in 
twee of meer stadia opgezet), verklaren 'geslacht, 'distress" en "chronicity' (en "employment" = werkeride mensen hadden meer contacten) als enige een relatie met de eerste contacten. 'Distress' had een sterkere relatie met eerste contacten $(.20$, ws .16 voor het totaal); 'chronicity' juist met het total aantal contacten (.21 vs .18 voor eerste contact). (Tessler e.a., p. 360). Op zichzelf is dit een interessante uitslag, omdat het onderzoek dezelfde inhoudelijke benadering kent als het onze. Door verschil in schattingstechniek en de beperking tot ến praktijk geven ze geen steun aan onze verwachtingen maar ondergraven die ook niet.

\subsection{Andere vraagfactoren}

We hebben al kort aangestipt dat alle doktersbezoek waaraan geen klacht ten grondslag ligt buiten ons klachtenmodel valt. Weliswaar was ons uitgangspunt dat dit een te verwaarlozen proportie van de vraag naar diensten van de huisarts zou betreffen; er is echter één belangrijke uitzondering: doktersbezoek van anticonceptie gebruikende vrouwen.

In de uiteindelijke versie van ons model zal een extra variabele voor vrouwen in de vruchtbare leeftijd moeten worden opgenomen.

Een tweede beperking van de toepassing van het model heeft te maken met de impliciete gedachtengang dat de betrokken personen zelfstandig hun beslissing nemen al dan niet een dokter te raadplegen. Voor kinderen geldt deze regel in zijn algemeenheid niet. ${ }^{5}$ Aan deze groep cliënten zullen we nog een beschouwing moeten wijden.

\subsubsection{Klachten van kinderen}

Het werk van Barbara Wolfe (Wolfe, 1980, Wolfe en Van der Gaag, 1981) is gewijd aan gezondheidstoestand en doktersbezoek van kinderen. De als tweede genoemde publicatie geeft ons echter de beste aanknopingspunten, omdat daar een zelfde soort aanpak wordt voorgestaan als in dit proefschrift, namelijk thet opstellen van een herleide - vorm - vergelijking van de vraag naar medische diensten op basis van onder meer een structuurvergelijking voor de gezondheidstoestand, in dit geval van kinderen (Wolfe en Van der Gaag, 1981, 290). ${ }^{6}$ Hoewel er nog wel een en ander aan te merken is op de samenstelling van deze laatste variabele (bestaande uit het oordeel van de ouders over de gezondheidstoestand van het kind, aantal dagen ziek geweest gedurende het afgelopen jaar, de aanwezigheid wan lichamelijke handicaps of andere gezondheidsproblemen volgens de ouders, het bestaan van gedragsproblemen volgens de ouders en de aanwezigheid van een allergie, Wolfe en Van der Gaag, 295 en 300-301), vinden de auteurs dat inkomen van het gezin, volledigheid van het gezin, leeftijd en huidskleur van het kind, opleiding en al dan niet werken van de moeder, geslacht (jongens zijn minder 'gezond') en gezinsgrootte invloed hebben op de gezondheidstoestand (Wolfe en Van der Gaag, 298). 
Vergeleken met onze eigen resultaten voor wolwassenen vindt men eenzelfde verband met sociale status/inkomen, een negatieve relatie met leeftijd (kinderen van 0-5 jaar hebben meer gezondheidsproblemen dan oudere kinderen) en een omgekeerde relatie met geslacht. Jongetjes zijn vaker ziek dan meisjes.

Dit verbaast de auteurs (pag. 300), maar is overeenkomstig observaties van Natanson (1977, 16-18), die erop wijst dat de grote verschillen tussen mannen en vrouwen voor alle indicatoren van gezondheidstoestand pas intreden bij het eind van de adolescentie en het begin van de reproductieve leeftijd en dat in de 'preschool-age' jongetjes vaker en ernstiger ziek zijn dan meisjes. Perinatale sterfte is voor jongetjes hoger en ook doodgeborenen zijn vaker van het mannelijk geslacht (zie ook Fuchs, 1974, hst 1 en 2).

De door Wolfe en Van der Gaag gevonden (sterke) verbanden tussen volledigheid van het gezin en gezondheidstoestand van het kind, komt, als we denken aan de heterogeniteit van hun 'health index', overeen met de door ons bij volwàssenen gevondlen relatie tussen burgerlijke staat en emotionele labiliteit.

De overige gevonden verbanden (waarom kinderen van part-time werkende moeders ongezonder zouden zijn dan kinderen van full-time werkende moeders en die weer ongezonder dan kinderen van niet-werkende moeders) kunnen wij (evenals de auteurs) niet goed interpreteren. Wat 'gezondheidstoestand" aangaat zouden we voor kinderen een afwijkend model moeten opstellen waar lleeftijd positief met gezondheidstoestand samenhangt, een omgekcerde relatie met geslacht wordt geformuleerd (man $(-)$, vrouw $(+)$ ) en een positieve relatie met sociale status (hoe hoger, hoe beter de gezondheid).

'Neurotische labiliteit' van kinderen is een onderwerp apart. Zowel Aakster (1972) als Mechanic (1981) vinden dat de scores van volwassenen op een lijst met lichamelijke klachten zeer sterk samenhangen met een negatieve beschrijving van het gezinsmilieu (Aakster (1972) vindt een verband tussen 'desintegratie ouderlijk gezin' en de totaalscore op zijn klachtenlijst (p. $112 \mathrm{ev.)}$. Mechanic vindt dat de mate van affectie van de ouders een belangrijke invloed uitoefent op de neuroticisme-score van het kind. Kooij (1975) vindt als belangrijkste voorspellers van de mate van iemands huwelijksgeluk de beschrijwing van de kwaliteit van het huwelijk van de ouders en een neuroticisme-achtige maat voor 'geestelijke gezondheid."

De genoemde studies hebben gemeen, dat in alle gevallen inmiddels volwassen geworden kinderen achteraf de relatie tussen hun ouders en met hun ouders beschrijven. Wat dat betreft moet men zeer op zijn hoede zijn voor de val van een achterliggende onwrede met het bestaan-in-het-algemeen en verschillende aspecten daarvan in het bijzonder. Als onderzoekers echter op verschillende tijd en plaats telkens dezelfde resultaten vinden, moeten we hieraan aandacht besteden en (liefst niet achteraf) de relaties in het ouderlijk gezin van invloed onderstellen op de mede in lichamelijke klachten vertaalde geestelijke gezondheid var de kinderen. Onze kennis is echter te zeer fragmentarisch om al in termen van modelspecificatie te kunnen denken. 
Er is een factor die in de literatuur telkens naar voren komt en waarop we nog niet nader zijn ingegaan: gezinsgrootte. Kuyvenhoven en Touw $(1976,52,53)$ geven aan dat uit de literatuur tegenstrijdige bevindingen naar voren komen. Wolfe en Van der Gaag vinden een negatief verband tussen grootte van het gezin en gezondheid wan het kind. Van Eijk $(1979,101)$ vindt dat de medische consumptie van kleine gezinnen (1-2 kinderen) hoger is dan die van grotere gezinnen.

Gezinsgrootte staat echter niet op zichzelf. Sociale, economische en culturele factoren zijn van invloed op de grootte van het gezin en zullen waarschijnlijk de tegenstrijdige resultaten verklaren. De invloed van gezinsgrootte zal men bijwoorbeeld onder conditie van sociaal economische status en religie moeten bestuderen, will men interpreteerbare resultaten krijgen.

\subsubsection{De invloed van verzekering tegen ziektekosten en inkomensderving} Over de invloed van de wijze van verzekering tegen ziektekosten op het gebruik van woorzieningen in de Nederlandse gezondheidszorg, zijn de geleerden het niet eens. Aan de ene kant vindt men in het proefschrift wan Marijke Mootz als stelling (Mootz, 1981, stelling 3): 'Als ziekenfondspatiënten dan al eerder medische hulp inroepen dan particulier verzekerden, komt dat niet door hun specifieke verzekeringsworm'; anderzijds leest men bij Van der Gaag (1978, 45): 'It is somerimes argued in the Netherlands that the increase in medical consumption could be stopped by introducing coinsurance rates and deductibles in the health insurance systems. Our results do show, that a reduction of health care demand can be expected among the "poor" '. Van de Ven (1980) verwacht dat het effect van de (geld)prijs op de vraag naar medische hulp (ceteris paribus) groter is naarmate a) iemands tijdprijs lager is b) de patiënt meer invloed heeft op de beslissing om medische hulp te ontvangen c) de patiënt gezonder is en d) het inkomen van de patiënt lager is (Van de Ven, 1980, 157).

Van der Gaag baseert zijn opmerking op de analyse van contactfrequenties uit het gezondheidscentrum Ommoord over het jaar 1972. Mootz laat zien (Mootz, 1978) dat verschillen tussen ziekenfonds en particulier verzekerden verdwijnen als men rekening houdt met sociale status, inkomen en gezondheidstoestand. Deze laatste variabele meet zij echter met behulp van de VOEG-score, waarvan we in het eerste deel van ons betoog hebben vastgesteld, dat die niet ondubbelzinnig gezondheidstoestand meet. Van de Ven en Van Vliet bevestigen overigens in hùn bewerking van het LSO-materiaal het resultaat van Mootz. Van een invloed van de verzekeringswijze 'sec' (althans voor de wijze waarop dit gegeven in het LSO 1977 gemeten is) onafhankelijk van de klachten van de respondent vinden zij niets.

Wel beschrijft Van de Ven in een aantal artikelen (Van de Ven, 1980, a-c; Van de Ven, Nauta, Van Vliet en Rutten, 1980, Van de Ven, 1981 a en b, Van de Ven en Van Praag, 1981) consumptieverschillen tussen ziekenfonds en particulier verzekerden.

Op elk gebied maken particulier verzekerden minder gebruik van voorzieningen in 
de gezondheidszorg dan collectief verzekerden. En dat waar iedereen (behalwe de 'at arms length' opererende ziektekostenverzekeraars) er toch belang bij heeft dat zij de woorzieningen ruimschoots gebruiken. De huisarts kan er de marge van zijn inkomen mee vergroten; de specialist krijgt voor klinische hulp van de particulier verzekerde wolgers tarief $3 \mathrm{e}$ klas $2 \times$ zoveel ais voor een $Z F$-patient en voor $2 \mathrm{e}$ kias verzekerden nogeens $75 \%$ daar bovenop (Van de Ven, 1981 a, 527 ) en toch worden particulieren minder vakk opgenomen, liggen ze korter in het ziekenhuis en hebben ze minder contact met de huisarts."

Of deze samenhangen nu aan de verzekering toe te schrijwen zijn, kan echter niet zonder meer worden geconcludeerd. Zo is de ene particulier de andere niet; volgens Van de Ven (1981a,526) is ongeveer de helft van de particulieren voor huisartsenhulp verzekerd; heeft ongeveer $\%$, aen verzekering volgens tarief 3 e $k$ latse en heeft ongeveer $30 \%$ een zogenaamd 'hoog eigen risico aan de woet'. Extra complicerend is ook nog dat het net verplicht verzekerde deel van de bevolking onder de inkomensgrens die gelijk is a an de loongrens voor de verpliche verzekering, de keuze heeft tussen het ziekenfondspakket op wrijwillige basis en cen particuliere zioktekostenverzekering. A fhankelijk van gezinsgrootte en een te verwachten risico zal men van de ene naat de andere verzekering kunnen overgatan (Van de Ven. 1981b). De agentschapsrelatie tussen (huis)ants en patient wort met dergelijko gegevenheden niet eenwoudiger; zot een arts dit allemaal vam aijn patiënten weten? Als we de onderzoeksresultaten van Wilensky en Rossiter (1981) moeten gelowen. zou men hast zeggen van wel. Op grond van een analyse van interessante gegevens stellen zij een model op dat moet verklaren of een contact met de gezondheidszorg op iniriatief van de patient of van de arts plaatsvindt. ${ }^{13}$ Eén van de belangrijkste verklarende variabelen voor de 'physician initiated contacts' is het percentage eigen bijdrage voor de patiënt. Hoelager dit is, hoe groter de kans op een iniviatief van de zijde van de arts.

Bij een dergellik complex geheel van risico-afweging past onderzoek warin:

a. de verschillende verzekeringsvormen veel preciezer gemeten zijn dan met de ruwe dichotomie "ziekenfonds/particulier"

b. met betrekking tot de consumptie duidelijk te onderscheiden is op wiens initiaticf dezc heeft plaats gevonden

c. liefst ook de kennis van de "agent' over de verzekeringswijze bekend is

d. een geldige (dus geen pur subjectieve, symptoom-achtige) mat voor de gezondheidstoestand van de verzekerde in thet onderzoek is opgenomen."

Pas dan kan men, voor de Nederlandse situatic. uitspraken doen over her mogelijke effect wan de invoering van een eigen risico op dit terrein. ${ }^{2}$

Wij verwachten overigens wel dat de wijze van verzekering enig effect zal hebben en wel in die zin dat de hoogte van de 'coinsurance rate", zoals de Amerikanen 'eigen bijdrage' noemen, een negatief effect op de vraag natr voorzieningen zal hebben. Darvoor is uit andere systemen van gezondheidszorg een grote hoeveelheid aanwijzingen. In vele systemen wan gezoncheidszorg heeft men geëxperimentee rd met 
het ene en het andere verzekeringsstelsel: lopend van wijzigingen in de hoogte van de eigen bijdrage (zoals bijvoorbeeld in Belgie (het remgeld) en in Frankrijk) tot een volledige wijziging van het systeem. Een interessant gewal vormt de Canadese provincie Saskatchewan, waar men in 1968 een eigen bijdrage voor medische diensten en ziekenhuis-gebruik introduceerde en in 1971 weer afschafte (Beck en Horne, 1980) en men bovendien beschikt over gegevens over een lange periode. Beck en Horne beschrijven inderdaad een terugval in de consumptie van $5,6 \%$ in het bijbetalingstijdperk, althans in het gebruik van diensten van huisartsen en specialisten. Ziekenhuisbezoek en verplleegduur zijn in de periode niet verminderd (zie ook v.d. Ven 1980b).

De Amerikaanse Rand Corporation pakt de zaak nog rigoureuzer aan; men heeft twee onderzoekingen lopen (zie de bijdrage van de Rand Corporation aan het Leidse economencongres, Manning e.a., 1981) waarin men experimenteert met verschillende verzekeringsvormen en men er voor zorgt dat zoveel mogelijk omstandigheden gelijk zijn. De voorlopige resultaten van dit onderzoek wijzen op een invloed in de verwachte richting (Manning e.a., $119 \mathrm{ev}$ ).

Wel dient men te beseffen dat de verschaffers van zorg een teruglopende vraag op initiatief van de patiënt met extra door henzelf geîndiceerde verrichtingen gedeeltelijk kunnen compenseren (zie van de Ven 1980b); in een systeem waarin de hulpverleners per verrichting worden betaald, althans: Hoe het effect van een eigen bijdrage zou uitwerken in het Nederlandse abonnementsysteem van huisartsenzorg is moeilijk te zeggen. De 'kopersstaking' van de particuliere patiënt is in zoverre succesvol geweest dat de beroepsorganisatie van huisartsen (de Landelijke Huisartsen Vereniging) voorstander is geworden van een algeheel abonnementsysteem. In een dergelijk systeem is het niet waarschijnlijk dat hulpverleners een teruglopende vraag gaan compenseren door meer verrichtingen te doen. Per saldo betekent dit dat een eigen bijdrage het aantal contacten tussen huisarts en patiënt juist in een abonnementsysteem zal doen verminderen.

Een analoge redenering kan men opzetten voor het effect van de mate van verzekering tegen inkomstenderving, zij het dat in de studies over dit effect (Philipsen, 1969, Smulders, 1980, Von Eije, 1981, om slechts enkele uit een lange reeks te noemen) frequentie en duur van het arbeidsverzuim centraal stan en niet het aantal contacten met huisarts of andere hulpwerleners. Philipsen (1969) vindt dat in bedrijven die 'wachtdagen' kennen de frequentie in het ziekteverzuim lager is, maar de gemiddelde ziekteduur zoveel langer dat het aantal ziektedagen groter is dan in bedrijven waar het loon volledig wordt door betaald. Dit gegeven brengt Von Eije (1981) tot de conclusie dat het invoeren van wachtdagen waarbij de werknemers de kosten van het arbeidswerzuim dragen, door de verwachte verlenging van de verzuimduur weinig effect heeft.

Toch zijn er ook wel aanwijzingen dat van een beperktere dekking tegen inkomensderving bij ziekte een consumptieremmend effect uitgaat. In het rapport "medische consumptie' (1974) is een van de weinige structurele variabelen die 'iets doet' bij 
mannen het gegeven 'loondienst/zelfstandig'. Deze dichotomie betreft uiteraard mér dan alleen een verzekering tegen inkomstenderwing. Toch is het niet onwàrschijnlijk dat een beperkte dekking tegen inkomensderving niet alleen het arbeidsverzuim beînvloedt maar ook, zij het dat de orde van grootte van het effect niet voorspelbaar is, enigermate van invloed zal zijn op de vraag naar diensten van de huisarts. ${ }^{13}$

\section{Conclusie}

Als we doktersbezoek onderscheiden in contacten op initiatief van de patiënt en contacten op initiatief van de huisarts (de typen 1 en 3 van Feldstein's typologie van

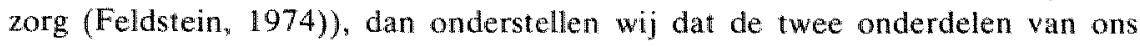
klachtenmodel (slechte gezondheid en neurotische labiliteit) beide positief zullen samenhangen met de vraag naar diensten van de huisarts op initiatief van de patient. De op neurotische labiliteit terug te voeren klachten zullen echter gevoeliger zijn voor de mogelijkheid die de huisarts heeft om zijn patiënten terug te bestellen, respectievelijk door middel van een verwijzing tijdelijk uit zijn invloedssfeer te verwijderen.

Daarnaast verwachten wij een groter aantal contacten tussen huisarts en vrouwen in de vruchtbare leeftijd dan op grond van dit klachtenmodel voorspeld kan worden. Voor doktersbezoek van kinderen heeft het klachtenmodel andere determinanten en tenslotte verwachten wij een geringe vraag naar diensten van de huisarts op eigen initiatief, zowel als op initiatief van de arts voor hen die niet voor huisartsenhulp zijn verzekerd. Of we dit resultaat ook in het Leef Situatie Onderzoek zullen vinden is echter de vraag. In dit onderzoek is de variabele "verzekering tegen ziektekosten" gebrekkig geoperationaliseerd. Bovendien vonden én Mootz $(1978,1980)$ ên Van Vliet en Van de Ven (1982) in hun analyse van ditzelfde materiaal geen verband meer tussen verzekeringsvorm en doktersbezoek na het uitschakelen van het effect van 'lichameli jke klachten'. We houden het er voorlopig maar op dat het LSO 1977 niet het geschikte bestand is om het effect van 'verzekering sec' te onderzoeken.

\subsection{Aanbodfactoren}

Aanbodfactoren, in de zin van productiefactoren, het exploiteren van technische hulpmiddelen en hulppersoneel, om de schaarse eigen tijd zo productief mogelijk te besteden, zijn voor de Nederlandse huisartspraktijk met z'n abonnementsysteem voor het merendeel der patiënten slechts van beperkt belang.

Dat het ook anders kan leert ons een beschrijwing van een werkdag van een Duitse huisarts, gezien door de ogen van een (verbijsterde) Britse collega (Hull, 1980). Deze beschrijft hoe een Duitse huisarts, met wie hij een dagje meeloopt, in staat is op éćn spreekuur 109 patiënten te behandelen, door gebruik te maken van een 
aantal onderzoekkamers, 15 man hulppersoneel die de anamnese afnemen, het probleem omschrijuen, de patiënt in het vereiste stadium van ontkleding in de juiste onderzoekkamer deponeren, achter de huisarts aanlopen en zijn opdrachten onmiddellijk uitvoeren. De omzet van de praktijk werd door Hull geschat op een miljoen Dmark, met een eigen inkomen van de huisarts na belastingaftrek van 130.000 mark (Hull, 1980,610).

Dergelijke koortsachtige activiteiten, zullen we bij een Nederlandse huisarts (of bij een Engellse - Hull merkt tot slot op dat hij liever geen dokter zou zijn, dan op die wijze) niet gaw tegenkomen.

In de Nederlandse gezondheidszorg zijn andere aanbodfactoren te onderscheiden. Sommige aanbodfactoren hebben te maken met de ligging van de praktijk, of liever met de verhouding tussen de plaats waar de praktijk is gevestigd en het woonadres van de patiënt. Andere aanbodfactoren hebben betrekking op de wijze van praktijkvoering van de huisarts, zoals het soort spreekuur en het aantal spreekuren, de mate van delegatie wan taken, de verhouding consult/visite enz.

Deze laatstgenoemde variabelen laten zich het best in 'praktijkstudies' bestuderen omdat het effect eerder vast te stellen is op het gemiddeld geaggregeerd aantal contacten uit de praktijkpopulatie, dan dat men nu bij iedere patiënt afzonderlijk een effect zal kunnen meten.

Beschikt men, zoals wij, over gegevens van individuen uit alle mogelijke huisartspraktijken en weet men bovendien niet uit welke huisartspraktijk de patienten afkomstig zijn, dus welke aanbodkenmerken voor die patiënt van toepassing zijn, dan moet men bijvoorbaat vaststellen, dat de kans vrijwel is uitgesloten dat men in een steekproef van individuen, die men niet ondervraagt over de kenmerken van de praktijk van hun huisarts, een verband vindt tussen deze kenmerken op geaggregeerd niveau en de door het individu opgegeven aantal contacten met de huisarts.

Niettemin formuleren wij, voor de volledigheid wel enkele verwachtingen, met name over de invloed van een factor als 'praktijkgrootte'. Deze werwachtingen kunnen wij deels toetsen aan de hand van het door ons verzamelde Engelse materiaal en voor een ander deel moet dat in nieuw onderzoek plaatsvinden.

\section{Locanic nan de prakrijk}

De invloed van afstand tussen consument en voorziening is voor wat betreft het gebruik van intramurale gezondheidszorg in een groot aantal studies aangetoond (Drop, 1971, voor wat betreft opname in psychiarrische ziekenhuizen, Raupp (1971), Kruidenier (1976), Posthuma en Van der Zee (1977, 1978), Dopheide (1982) voor de verwijscijfers uit huisartspraktijken, de laatsten al dan niet tot gemeenten samengevoegd). Van de Ven en Van Praag (1981) vinden een sterk verband tussen de bij de ziektekostenverzekeraars geclaimde bedragen en de afstand tussen verzekerde en ziekenhuis. Ook in de economische benadering van de gezondheidszorg is sinds het artikel van Acton (1975) de belangstelling voor niet- 
geld-gebonden factoren toegenomen. Vaak worden wacht- en reistijd samen genomen. Wij willen hiertussen echter een onderscheid maken. Deze locatie - of afstandsfactor (het hangt er maar vanaf van welk gezichtspunt het wordt bekeken) 'werkt' ook in de huisartspraktijk. Parkin (1979) vindt in een Londense huisartspraktijk voor vrijwel alle leeftijd/geslacht/status categorieën in de patiëntengroep per afstandszône lagere contactfrequenties naarmate de patiënt verder weg woont. Hij bevestigt hiermee de resultaten van Morell e.a., die in 1970 in hun praktijken hetzelfde vonden (Morell, 1970).

Voor zover ons bekend, is een dergelijk onderzoek in Nederland niet uitgevoerd. Gezien de vergelijkbaarheid van de Engelse met de Nederlandse eerstelijnsgezondheidszorg op dit punt is er echter geen reden om aan te nemen dat 'afstand' niet van invloed zou zijn.

De afstandscategorieën die Parkin gebruikte $(<1 / 4 \mathrm{mijl}= \pm 400 \mathrm{~m})(0,25-0,625$ $\mathrm{mijl}=400 \mathrm{~m}-1 \mathrm{~km})(>0,625 \mathrm{mijl}=>1 \mathrm{~km})$ geven vooral een verschil tussen categorie $3(>1 \mathrm{~km}$ ) en de rest (voor de totale populatie: zone $3: 3.53$ consulten; zone $2: 5.18$ en zone $1: 5.07$ consulten). Het verschil in percenten is ongeveer $45 \%$ als men uitgaat van de verste categorie en $31 \%$ als men de andere twee categorieën als uitgangspunt neemt. De grootste verschillen vond Parkin bij de patiënten ouder dan 64 jaar (vrouwen > 64; zone 1: 8.97 consulten; zone $2: 7.12$ consulten en zone 3: 3.02 consulten). De verschillen gelden, volgens Parkin, (hij laat echter geen tabellen zien) zowell voor contacten op initiatief van de patiënt als voor contacten op initiatief van de huisarts.

Gezien de omvang wan de verschillen moet een toenemend aantal spreekuurpunten (een gedeeltelijk gevolg van de toename van het aantal huisartsen) onherroepelijk leiden tot een vergroting van het aantal arts/patient contacten. ${ }^{14,}$ is

\section{Spreekuuriijd}

Het kostbaarste goed dat een huisarts te bieden heeft is zijn eigen tijd. Het aantal spreekuren, voor zijn gehele praktijk of voor een gedeelte er van (er zijn nog steeds huisartsen die er aparte ziekenfonds- en particuliere spreekuren op na houden); de verdeling van de spreekuren overdag; extra avond- en weekendspreekuren voor hen die moeilijk door de week kunnen komen, vormen even zovele manieren waarop de huisarts zijn tijd kan ambieden.

Bovendien kan de huisarts ook nog beslissen of hij patiënten thuís bezoekt of bij zich op het spreekuur laat komen.

Het aantal uren per dag staat niet vast; dit kan de huisarts in belangrijke mate bepalen.

Door middel van hulppersoneel kan hij zijn productie verhogen, zij het dat de prikkels hiertoe in het Nederlandse abonnementsysteem niet erg groot zullen zijn; er is wellicht zelfs eerder sprake van reductie en beheersing van het aantal contacten met behulp van afspraakboeken en door de assistente streng bewaakte spreekuur- 
tijden dar yan het zo efficiënt mogelijk verwerken van een zo omwangrijk mogelijke patiêntenstroom. ${ }^{16}$

In de Nederlandse gezondheidszorg kan een huisarts zijn inkomen verhogen door tijd wrij te maken voor nevenwerkzaamheden en door het verstrekken van extra zorg aan particuliere patiènten. Voor het overige staat zijn inkomen los van de direct geleverde prestatie. Dit betekent dat de uitkomsten van onderzoek verricht in systemen van gezondheidszorg waar artsen hun inkomen rechtstreeks uit geleverde diensten ontvangen (een mooi voorbeeld is Sloan's studie naar 'physicians hours of work decisions' (Sloan, 1974), slechts beperkte geldigheid , hebben. ${ }^{17}$

Het afwegen van 'inkomen' en 'vrije tijd', in de micro-economie het klassieke keuzemodel voor het verklaren wan het gedrag van economische subjecten - de al eerder genoemde studie wan Sloan is een mooi voorbeeld daarvan - is in de Nederlandse gezondheidszorg veel indirecter. Het inkomen van de huisarts staat min of meer vast met het aantal ingeschreven patienten en heeft geen directe relatie met de bestede tijd.

Het klassieke model waarin inkomen en vrije tijd worden afgewogen heeft voor zijn toepassing in de gezondheidszorg hier en daar aanvulling ondergaan. Evans (1976) kritiseert Sloan's aanpak omdat in Sloan's studie de vraag naar diensten van de arts. geheel als exogeen worden beschouwd. Sloan gaat niet in op de mogelijkheid die een arts heeft om de vraag naar zijn eigen diensten te scheppen.

In Evans' model (1974) moet een arts naast de verhouding inkomen/vrije tijd ook de negatieve effecten ('disutilities') betrekken van het scheppen van de vraag naar zijn eigen diensten. (Evans, 1974, 166).

Dit betekent dat de analyse van vraag/aanbod relaties in de gezondheidszorg aanmerkelijk complexer wordt dan als men onderstelt dat voor een hulpverlener een eenvoudige rangschikkingsfunctie van inkomen en vrije tijd van toepassing is. Nu immers, verlopen de indifferentiecurves, de verzameling van combinaties van de twee componenten (inkomen, vrije tijd) niet regelmatig (i.c. "bol naar oorsprong"). De daaruit voort vloeiende fundamentele onevenwichtigheid in het systeem, maakt dat in ieder geval rekening gehouden moet worden met professionele opvattingen over de hoeveelheid te leveren zorg en de factoren die dit beïnloeden. Evans' afwegingstheorie is door Willensky en Rossiter gebruikt om wit te zoeken welke factoren de mate bepalen waarin artsen hun vraag scheppen. Genoemd hebben we al de hoogte van de 'eigen bijdrage" (hoe hoger de bijdrage, hoe geringer de kans op een contact op initiatief van de dokter). Andere factoren die de kans beinvloeden dat een contact op initiatief van de arts heeft plaats gevonden zijn: aantal dokters per 1000 inwoners (hoe meer, hoe groter de kans), geslacht wan de patiënt (bij vrouwen grotere kans), slechte gezondheid en gezinsinkomen (hoe hoger, hoe geringer de kans). De leeftijd van arts, tenslotte heeft ook invloed; hoe jonger de arts hoe groter de kans op terugbestellen (Wilensky en Rossiter, 230). 18 Deze samenhangen gelden allemaal woor systemen waarin het de patiënt iets kost en het de dokter iets oplevert in materiële zin als deze zijn eigen wraag schept. In het 
Nederlandse systeem geldt voor het ziekenfondsgedeelte van de praktijk dat het de huisarts wel tijd kost, maar geen extra opbrengst in materiële zin en dus ook geen negatieve effecten wat betreft zijn beroepsopvarting met zich meebrengt als hij een patiënt terugbestelt. Dit terugbestellen moet men overigens zeker niet opvatten als het scheppen van niet-noodzakelijke diensten. Al te veell nadruk op de "demand generating capacity" van hulpverleners doet licht vergeten, dat het scheppen van de vraag naar eigen diensten in het algemeen als achtergrond heeft dat ernstiger aandoeningen of de gezondheidstoestand van $k$ wetsbare groepen uit de praktijk (kleine kinderen, oude mensen, zwangere vrouwen) extra zorg behoeven. Zweifel (1981) noemt dit een 'ethisch aspect". Hij neemt in zijn model ter verklaring van het economisch gedrag wan artsen een variabele op die uitgaat van de hoeveelheid tijd die de arts volgens zijn beroepsnormen, gegeven de ernst van de situatie, moet aanwenden om de toestand van de patiënt te verbeteren.

Terugbestellen of het inroepen van de hulp van een, gegeven het probleem, deskundiger hulpverlener (consultatie, verwijzen) vinden voor een belangrijk deel hun oorzaak in de ernst van de door de patiënt aangeboden problematiek. Niettemin kan de Nederlandse huisarts zijn inkomen verhogen door het laten inschrijven van een groter aantal patiënten op zijn naam, het verlenen van zorg aan particuliere patiënten en het verrichten van nevenwerkzaamheden. Voor de laatste twee bezigheden heeft hij tijd nodig. De tijd kan hij, zonder dat dit inkomensverlies oplevert, "halen' bij het terugbestellen wan ziekenfondspatiënten en wel op twee manieren: door bij minder ernstige gevallen het terugbestellen te reduceren en bij ernstige gevallen tot een verwijzing over te gaan, gegeven althans de mogelijkheden tot verwijzen. Ook in het geval dat het inkomen voldoende wordt geacht, kan de hoeveelheid tijd, zonder inkomensverlies beperkt worden door het reduceren van het aantal terugbestelcontacten van ingeschreven $\mathrm{ZF}$-patiënten. Verwijzen of in het algemeen - niet terugbestellen - zijn de mogelijkheden hiervoor.

Samenvattend kunnen we stellen dat in de Nederlandse gezondheidszorg de terugbestelcontacten voor ziekenfondspatiènten het meest gevoelig zullen zijn voor de omvang en organisatie van de huisartspraktijk en dat gegeven de mogelijkheid om patiënten te verwijzen (afstand tot en omvang van specialistische voorzieningem) verwijzen en terugbestellen elkaar zullen substitueren. Wij verwachten echter dat terugbestellen, evenals verwijzen overigens voor een belangrijk deel een functie zal zijn van de ernst van de aangeboden problematiek, hetgeen de manoeuvreerruimte van de huisarts aan banden legt, zij het niet geheel bepaalt.

\section{Verwachingen}

Wij verwachten dat de volgende factoren aan de aanbodzijde van invloed zijn op de vraag naar diensten van de huisarts op initiatief van de patient en van de huisarts. De gemiddelde afstamd tor het praktijkpand (ofwel op geaggregeerd niveau de dichtheid van spreekuurpunten) beïnloedt het aantal contacten (op initiatief van de huisarts en van de patiënt) negatief. 
Praktijkgrootte zal het aantal contacten op initiatief wan de patiènt niet of nauwelijks beinvloeden maar het aantal terugbestelcontacten wel. Afhankelijk van de mogelijkheden om patienten te verwijzen zal een geringer aantal terugbestelcontacten gepaard gaan met een groter aantal verwijzingen. Dat wil zeggen dat we verwachten dat de relatie tussen praktijkgrootte en het aantal terugbestelcontacten sterker zal zjn op plaatsen met veel verwijsmogelijkheden dan in plaatsen waar de mogelijkheden tot verwijzen beperkt zijn; dit geldt des te sterker bij minder ernstige klachten. De wijze van praktijkvoering achten we in het Nederlandse systeem van weinig invloed omdat het abonnementsysteem productiviteit niet stimuleert. Het hanteren wan een afspraakspreekuur zou van invloed kunnen zijn op het aantal eerste contacten; terugbestellen gaat heel goed met zo'n systeem en heeft voorrang boven spontane bezoeken. Ook kan de concentratie van praktijkadressen, die kenmerkend is voor meermanspraktijken door de grotere gemiddelde afstand een reductie in het aantal contacten teweegbrengen.

\subsection{Samenvatting}

Naast factoren als slechte gezondheid en de neiging tot klagen op uitnodiging zijn er zowel alan vraag- als aanbodzijde in de gezondheidszorg andere factoren die de gerealiseerde vraag naar diensten van de huisarts bepalen. Deze gerealiseerde vraag valt te splitsen in een vraag op initiatief van de patiënt en een vraag op initiatief van de huisarts.

De neiging om 'klagen-op-uitnodiging" om te zetten in een contact met de huisarts zal vooral beînwloed worden door de ruimte die de huisarts heeft om zijn patiënten terug te bestellen. Deze ruimte wordt bepaald door het aantal contacten op initiatief van de patiënten en dat is weer een functie van vraggtactoren als leeftijd en geslacht (gezondheidstoestand). Hoe slechter iemands gezondheid, des te sterker is zijn vraag naar arts/patiënt-contacten en vooral naar terugbestelcontacten. De huisarts kan dit soort contacten alleen reduceren als hij de betrokken patiënten kan verwijzen. Dït laatste kan hij beter naarmate zijn praktijk dichter bij een algemeen ziekenhuis gevestigd is en er naar verhouding meer behandelende specialisten in de buurt zijn gevestigd.

Naast de invloed van factoren uit het klachtenmodel verwachten we dat vrouwen in de vruchtbare leeftijd de huisarts vaker zullen consulteren en dat het on breken van een verzekering tegen huisartsenhulp of een slechte verzekering tegen inkomstenderving het aantal contacten met de huisarts negatief zullen beinvloeden.

Wat betreft de factoren aan de aanbodzijde verwachten we een geringer aantal contacten (le en terugbestel) naarmate de patienten gemiddeld verder van het praktijkpand wonen (dat wil zeggen naarmate de spreekuurpunten meer geconcentreerd zijn) en dat de huisarts zijn terugbestelcontacten zal reduceren naarmate zijn praktijk groter is. Deze relatie zal minder sterk zijn naarmate hij zijn patiënten gemakkelijker kan verwijzen en naarmate de klachten emstiger zijn. 


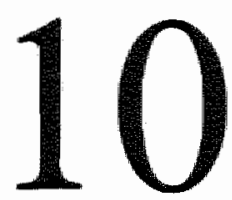

\section{Resultaten 2. Eerste contacten, terugbestelcontacten en verwijzingen. Gegevens uit Engelse gezondheidszorg.}

\subsection{Inleiding}

De in het vorige hoofdstuk geformuleerde verwachtingen kunnen we slechts ten dele toetsen. Eén deel wordt gevormd doon analyse van gegevens uit een zestigtal Britse huisartspraktijken, in welke analyse we enige notie kunnen krijgen van de werking van een aanbodfactor als de omvang wan een huisartspraktijk. Een tweede deel wordt besproken in hoofdstuk 11, waar we, onder veel voorbehoud, het verband tussen klachten en andere vraagvariabelen en het aantal coniacten met de huisarts aan de hand van gegevens uit het Leef Situatie Onderzoek 1977 willen bestuderen.

Gegevens uit een voldoende groot aantal huisartspraktijken bestaan in Nederland niet.

Hoewel de Nederlandse en de Engelse gezondheidszorg niet veel gemeenschappelijks hebben, komen, wat betreft de plaats van de huisarts beide systemen overeen. Ook in Engeland is de huisarts vrij ondernemer en wordt hij per abonnement betaald. Particuliere patienten kent hij echter niet; dat is een verschil.

De plaats van de huisarts ten opzichte van de specialistische gezond heidszorg is ook vergelijkbaar; in Engeland moet men eerst langs de huisarts voordat men de specialist kan consulteren. De organisatie van de tweedelijnszorg is echter in beide landen volledig verschillend. In Engeland windt men alleen specialisten in loondienst en is het aantal bedden in algemene ziekenhuizen veel lager dan bijons ( $3.9 \mathrm{in}$ 1974 ws 5.5 bij ons, Schrijvers, 1980, 153). Dit betekent dat het de vraag is of in Engeland dezelfde relaties worden gevonden tussen verwijzingen en afstand tot en omvang van klinische voorzieningen.

Verbanden binnen het domein van de huisartspraktijk $k$ unnen we wel extrapoleren naar de situatie in Nederland; verbanden tussen huisartspraktijk en tweedelijns- 
gezondheidszorg zijn niet vergelijkbaar.

Gezien de grote moeite die het kost gegevens uit huisartspraktijken voor analyse en onderzoek beschikbaar te krijgen zijn wij zeer verheugd dat we van de 60 praktijken, die in het kader wan het tweede National Morbidity Survey (1970/1971) gedurende een jaar al hun contacten met patiënten hebben geregistreerd per praktijk en per leeftijds/geslachrsgroep de beschikking hebben gekregen over de volgende gegevens:
a. het aantal personen per leeftijds/geslachtsgroep
b. het aantal personen dat de dokter heeft bezocht
c. het aantal ziekte-episoden in het teljaar (ongeveer te interpreteren als het aantal contacten op initiatief wan de patiënt)
d. het aantal arts/patiënt contacten
e. het aantal verwijzingen (opname, poliklinisch, onderzoek).

Per praktijk is bovendien bekend of het om een stads- of plattelandspraktijk gaat en of het een solopraktijk of samenwerkingsverband betreft. Bovendien hebben we achteraf nog de afstand van de plaats waar de praktijk is gevestigd tot het dichtstbijzijnde algemeen ziekenhuis kunnen vaststellen ${ }^{19}$.

Wij kunnen met dit materiaal het verband vaststellen tussen kenmerken van de patiëntenpopulatie naar leeftijd en geslacht en de verschillende geregistreerde vormen van consumptie en bovendien bezien wat de invloed is van praktijkgrootte, praktijkworm en praktijklocatie (hoe primitief ook gemeten) op het aantal eerste contacten, terugbestelcontacten en verwijzingen.

Na een paragraaf over het 2 nd National Morbidity Survey zullen wij de resultaten van onze anallyse weergeven; eerst de verdeling van de verschillende consumptievormen per leeftijds/geslachtsgroep en vervolgens de invloed van praktijkgrootte, praktijkvorm en praktijklocatie op eerste contacten, terugbestelcontacten en verwijzingen.

\subsection{Het Second National Morbidity Survey in Engeland en Wales}

Om inzicht te krijgen in de in de huisartspraktijk gepresenteerde morbiditeit worden eens in de tien à vijftien jaar door het Engelse Royal College of General Practitioners en het Office of Population Censuses and Surveys (OPCS) in een aantal over Engeland en Wales verspreide huisartspraktijken gedurende een jaar alle arts/patiënt contacten geregistreerd en verwerkt. Het eerste survey vond plaats in 1955/1956, het tweede in $1970 / 1971$. Een verslag van het laatstgenoemde onderzoek werd in 1974 door de Engelse Staatsdrukkerij (Her Majesty's Stationery Office, HMSO) uitgegeven. In het totaal 60 praktijken met 115 huisartsen, registreerden van november 1970 tot en met oktober 1971 alle 'face to face' contacten met hun patiënten. ${ }^{20}$ De publicaties met de resultaten van dit onderzoek con- 
centreren zich vooral op de frequenties van aangetroffen ziekton en problemen per leeftijds- en geslachtsgroep en per regio.

Naast deze epidemiologische studies zijn de gegevens in algemene zin gebruikt voor onderzoek naar de statistische eigenschappen van de frequentieverdeling wan ziekte-episoden en consultaties. Kilpatrick (1975, 1977 a en b) maakt duidelijk dat de frequentieverdeling van aandoeningen en consulten zeer goed met een negatieve binomiaal-verdeling kan worden gekarakteriseerd. Het is alleen de vraag hoe stabiel de parameters van deze verdeling ( $\mu$; een soort gemiddelde en, $k$, die de vorm van de curve bepaalt) zijn. Per leeftijds- en geslachtsgroep zijn de warden voor $\mu$ en $k$ verschillend; per huisartspraktijk zijn soms (Kilpatrick, 1977a) flinke afwijkingen tussen de verwachte en gevonden waarden te zien. Aangezien wij niet over de frequentiverdeling van het aantal aandoeningen en consulten per leeftijds-geslachtsgroep per praktijk beschikken (alleen over het totaal aantal aandoeningen en consulten per leeftijds/geslachtsgroep per praktijk) hebben wij van Kilpatrick's methode geen gebruik kunnen maken voor het voorspellen van het aantal arts/patiënt contacten.

Dankzij de welwillende medewerking van Dr. D. L. Crombie, hoofd van de Research Unit van het Royal College of General Practitioners kregen wij de beschikking over de volgende gegevens:

per huisartspraktijk

1. praktijklocatie (plaats waarin de prakiijk is gevestigd)

2. aantal 'principals'; zelfstandig gevestigde huisartsen in de praktijk

3. stads/plattelandspraktijk per leefrijds/geslachtsgroep per huisartspraktijk

4. het aantal ingeschreven patiënten

5. het aantal personen dat in het teljaar de huisarts bezoekt

6. het antal ziekte-episoden; te splitsen in:

1. aantal episoden begonnen voor het teljaar

2. aantal nieuwe episoden in het teljaar

3. aantal nieuwe episoden voor reeds bekende problemen

4. aantal episoden begonnen buiten de huisartspraktijk

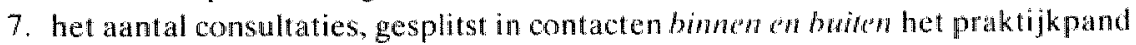

8. het aantal verwijzingen, gesplitst in:

1. acute opname

2. poliklinische verwijzingen

3. verwijzingen voor onderzoek

4. overige (paramedische, 'local health authority', multiple codes).

De in het onderzoek gebruikte leefrijdsindeling heeft ongelijke intervallen en luidt als volgt:

0. 4 jaar

5-14 jaar

15-24 jaar 
75 jatr en ouder.

Later is, met behulp van het Institute of Health Service Administrators te Londen, gepoogd de afstand van de plaats waar de praktijk is gevestigd tot het dichtstbijzijnde algemene ziekenhuis vast te stellen. Het is ons helaas niet gelukt om gedetailleerde informatie te verzamelen ower het aantal specialisten (consultants) en her aantal bedden per 1000 inwoners in elk der praktijkgebieden. ${ }^{22}$

Onze analyse van de invloed van tweedelijnswoorzieningen op een mogelijke substitutie tussen 'terugbestellen' en 'verwijzen' zal dus tamelijk grof moeten zijn.

\subsection{Beschrijving van het materiaal}

Voordat wij de relatie tussen praktijkvorm, praktijklocatie en praktijkgrootte enerzijds en eerste- en terugbestelcontacten en verwijzingen anderzijds analyseren, zullen we eerst het materiaal globaal beschrijven. Een aantal gegevens staat al vermeld in het aangehaalde rapport; andere zijn nog niet gepubliceerd.

Zoals gezegd gaat het om 60 praktijken; waarvan 31 solisten en 29 meermanspraktijken (total 115 huisartsen met 292247 patiënten - gemiddeld 2541 per huisarts). In tabel 10.1 zijn de belangrijkste gegevens uit het 2 nd NMS weergegeven. De gemiddelden wijken enigszins af van de totaalcijfers omdat van alle meermanspraktijken de gegevens eerst vergelijkbaar zijn gemaakt met die van solopraktijken door ze te delen door het aantal partners.

Het gemiddelde van deze gemiddelden plus de gegevens van de solopraktijken wordt hier gepresenteerd.

De gemiddelde praktijkgrootte wijkt niet sterk af van de huidige praktijkgrootte in Nederland; het aantal contacten is wat aan de krappe kant. Hicks (1976) heeft in een uitgebreid overzicht van Engelstallige literatuur over het onderwerp 'primary care' resultaten en methodiek van het Second National Morbidity Survey uitwoerig besproken. Vergeleken met het eerste Survey (1955/1956) en met de Engelse 'General Household Surveys' (te vergelijken met de Leef Situatie Onderzoekingen in Nederland) is het aantal arts/patiënt contacten niet erg hoog (1st Nat. Morb. Survey 3.8 contacten, General Household Survey 3.7 contacten; 2nd Nat. Morb. Survey 3.0 contacten, Hicks, 1976,153 e.w.). In Nederland vindt Oliemans (1969) 4.18 contacten per patiënt. ${ }^{23}$ Tussen de praktijken treft men de nodige variatie bij alle gegevens; er zitten altijd wel enkele praktijken op een grotere afstand van het gemiddelde dan plus of minus tweemaal de standaarddeviatie. Dat zijn overigens niets steeds dezelfden.

Wat betreft de verwijscijfers, is het de vraag of een vergelijking met de Nederlandse 
Tabel 10.1: Gemiddelden en standaarddeviaties woor 60 hwisertspraktiken van praktijkgrootte, eerste contacten, terugbestelcontacten en verwijzingen.

Second National Morbidity Survey - Engeland en Walies - $1970 / 1971$.

variabele

gemiddelde standaard-

minimum/maximum

deviatie

1. praktijkgrootte

2. $\%$ consulterende patienten in $1 \mathrm{jt}$

3. aantal episoden (1e contact.) per patiènt begonnen in jr vóór teljaar

4. aantal nieuwe episoden in teljaar per praktijk (eersite contacten)

5. aantal consultaties mimus nienwe episoden in teljaar (terugbestelcontacten 1) $p$. patient

6. aantal consultaties minus nieuwe episoden in en wór teljaar (terugbestelcontacten 2) per patiènt

7. percentage contacten buiten het praktijkpand (visites)

8. verwijzingen acute opnamen per 1000 patienten

9. verwijzingen polikliniek per 1000 patiènten

10. verwijzingen voor onderzoek per 1000 patiënten

$$
2647
$$

67.8

639

6.0

$1219-4423$

$41.0-82.1$

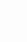

.221

$.967-2.885$

1.534

.509

$.530-2.959$

\subsection{3}

.443

$.397-2.604$

1.5 .8

8.77

$4.6-43.4$

20.7

10.73

$3.8-50.4$

93.2

42.53

$33.9-246.7$

118.6

$13.0-434.4$

gezondheidszorg mogelijk is. Voor $1970 / 1971$ bedroeg het ZF-verwijscijfer respectievelijk 438 en 457 per 1000 verzekerden (bron: Jaarverslagen van de Ziekenfondsraad), maar in Engeland hebben de cijfers betrekking op alle patiẻnten (men moet rekening houden met een 15 a $20 \%$ lager werwijscijfer voor particulieren (Van de Ven e.a., 1981) en kent men de z.g. "vervolgverwijzigen" niet. (In Nederland door huisarts uitgeschreven als de specialist de behandeling langer dan een jaar wil voortzetten). Ook worden 'brilrecepten' en controles t.v.b. refractie-afwijkingen in het algemeen niet met een verwijsbrief naar de oogarts gestuurd. Deze laatste verwijzingen bedroegen in 1969, volgens van Es en Pijlman resp. $25 \%$ en $22 \%$ (excl. dubbeltellingen) van het totaal. ${ }^{24}$ 
De categorie "verwijzingen voor onderzoek" bewat waarschijnlijk een aantal activiteiten dat in Nederland door huisartsenlaboratoria wordt afgewerkt. Als we verwijzingen voor onderzoek niet meetellen en het Nederlandse cijfer corrigeren voor "particulieren', 'refractie-afwijkingen" en 'vervolgverwijzingen', zijn de cijfers $2 \mathrm{Nd}$ NMS: acute + poliklinische verwijzingen per 1000 ingeschrevenen: 104. In Nederland bedraagt het aldus gecorrigeerde verwijscijfer $1970 / 1971 \pm 230$ per $1000 .{ }^{25}$ Alle verwijzingen inclusief onderzoek in Engeland 233 per 1000. Opname en polikliniek is flink wat lager in Engeland, hetgeen goed te verklaren is wit de restrictievere planning van de tweedelijns geneeskundige zorg aldaar.

\section{Naar leefiid en geslacht}

In de figuren 10.1-10.3 treft men de verdeling aan van de hiervoor beschreven gegevens per leeftijds/geslachtsgroep, in figuur 10.1 de verschillende consultgegevens, in 10.2 het percentage visites en in 10.3 de verdeling van de verwijscijfers.

Bij de grafische presentatie is er onderscheid gemaakt in de verschillende soorten contacten (de frequenties waarop de grafieken zijn gebaseerd vindt men in bijlage E).

De laagste frequenties worden gevonden voor hetgeen wij benoemd hebben als het aantal chronische aandoeningen. Letterlijk gesproken gaat het om het aantal episoden in het jaar voorafgaande aan het teljaar. Voor een klein deel zijn dit aandoeningen die optraden vlak voor het begin van het teljaar, en waarvan niet het eerste contact maar wel de terugbestelcontacten bekend zijn; net zo goed als de aandoeningen die aan het eind van het teljaar als aandoening worden genoteerd, maar waarvan het vervolg buiten het teljaar valt. Voor een ander deel zijn het chronische problemen, blijkens de sterke relatie met de leeftijd van de praktijkbevolking. Wat betreft de contacten op initiatief van de patiënt valt het op dat deze voor mannen vrijwel constant zijn na de piek van de eerste levensjaren. Het gestadig met toenemende leeftijd oplopen van het totaal aantal contacten voor mannen komt door de stijging van de terugbestelcontacten en chronische aandoeningen. Tussen de 40 en 45 jaar ligt het omslagpunt, dan zijn er voor mannen meer terugbestelcontacten dan contacten op initiatief van de patiënt. Men mag de conclusie trekken dat op geaggregeerd niveau de medische consumptie van mannen een functie is van hun door leefiid bepaalde fysieke conditie (let ook op de hogere frequentie voor jongetjes van 0.4 jaar).

Voor vrouwen is de reproductieve leeftijd van doorslaggevend belang voor het aantal contacten met de huisarts. Een vrouw van 20 wordt even waak terugbesteld als cen man (of een vrouw) van 70 . Het omslagpunt van contacten op initiatief van de arts en contacten op initiatief van de patiènt ligt bij vrouwen tussen de 50 en 60 jaar (of iets eerder; dat is vanwege de zeer ruwe leeftijdscategorieën niet vast te stellen).

In figuur 2: de verdeling van de proportie visites naar leeftijd en geslacht, zien we 
Figuur 10.11.: Contactfrequenties per leeftijdscategorie voor mannen en vrouwen uit het Second National Morbidity Survey in Engeland en Walles. 1970/71.

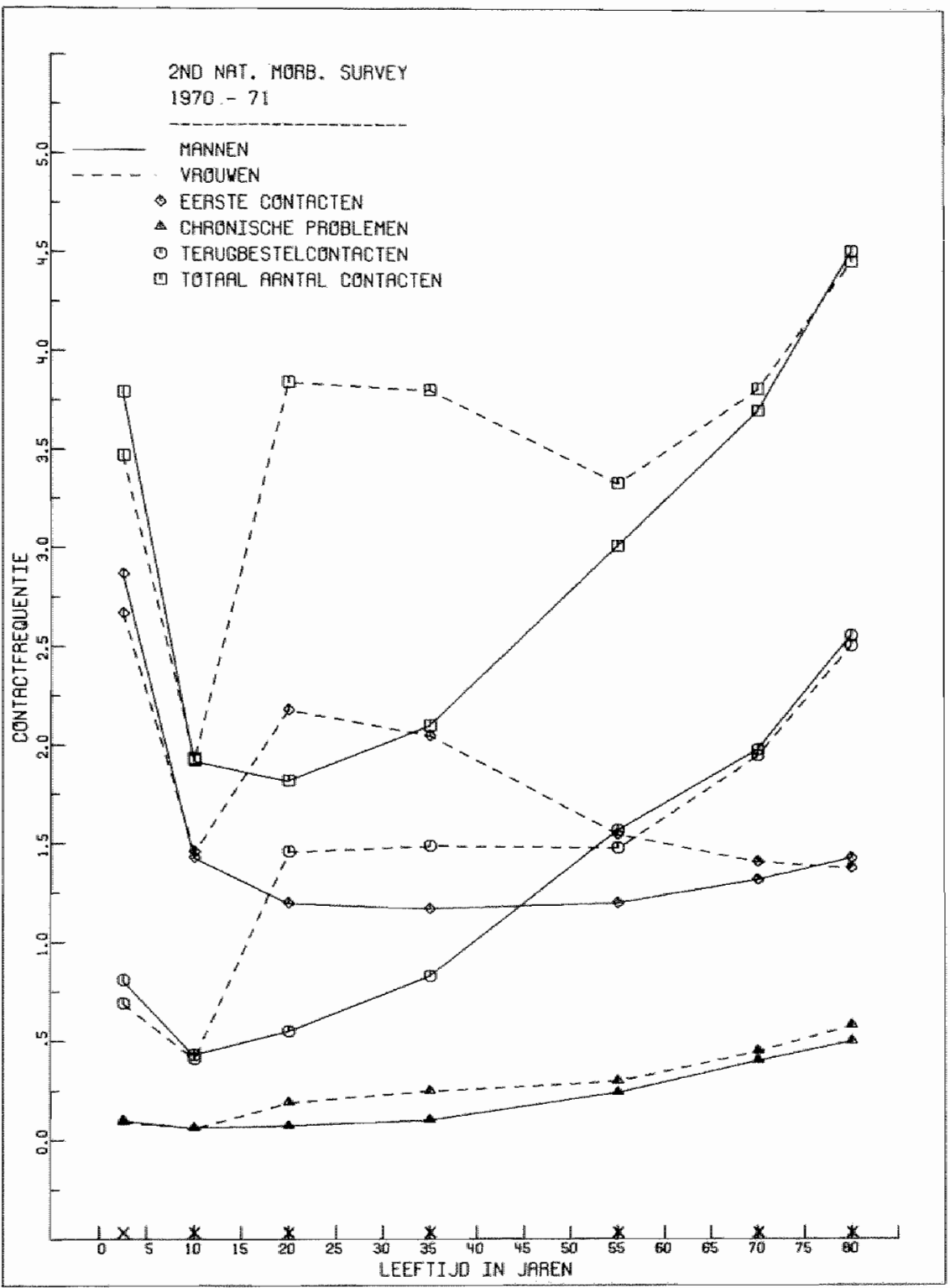


Figum 10.2: Percentage wistes per leeffidscategorie voor mannen en vrouwen wit bet Second National Morbidity Survey in Engeland en Wales. $1970 / 71$.

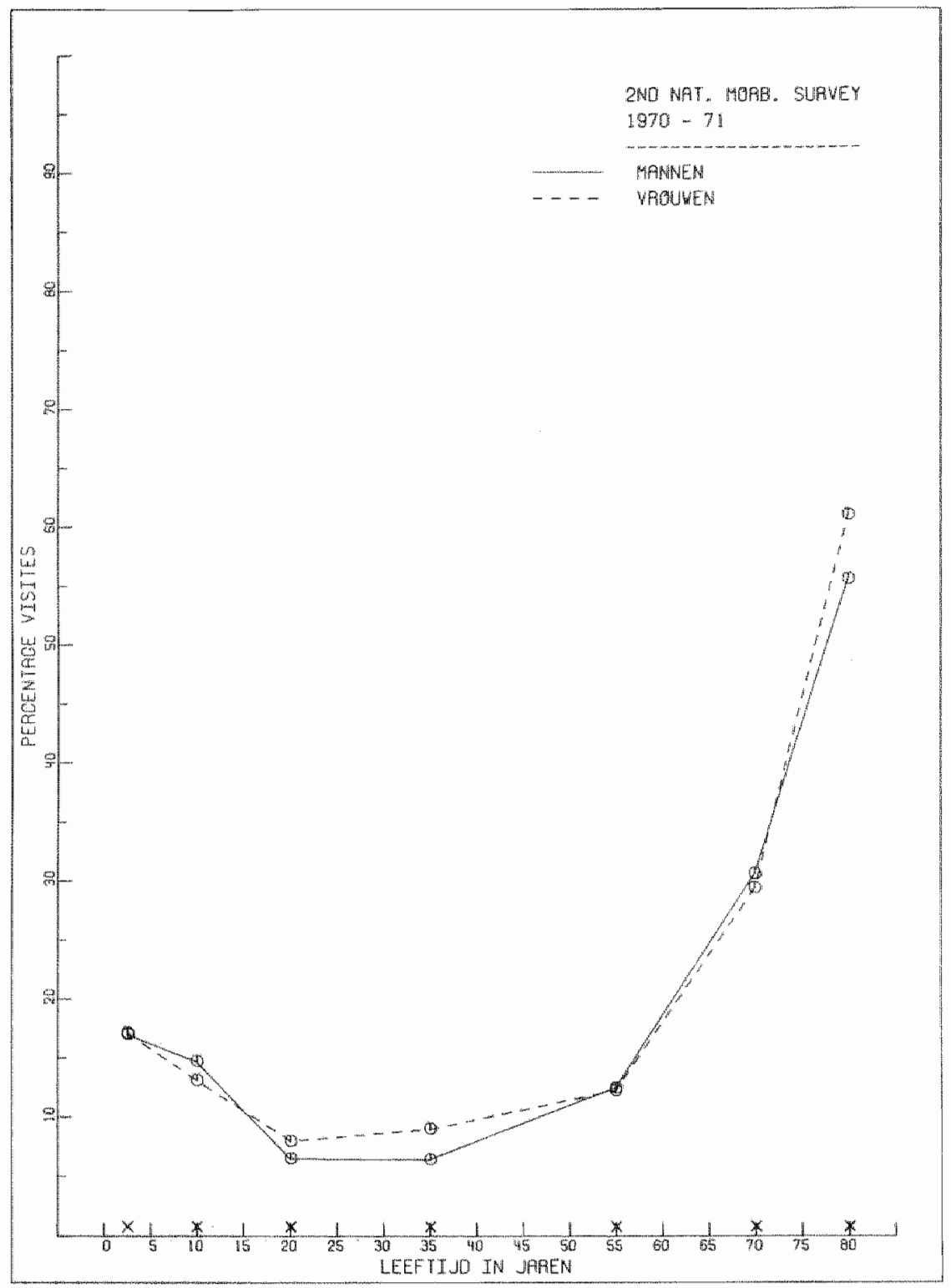


Figuur 10.3.: Verwijscijfers (opnamen, poliklinisch en onderzoek) foor mannen en vrowwen per leeftijdscategorie uit het $2 \mathrm{Nd}$ National Morbidity Survey in Engeland en Wales. $1970 / 71$.

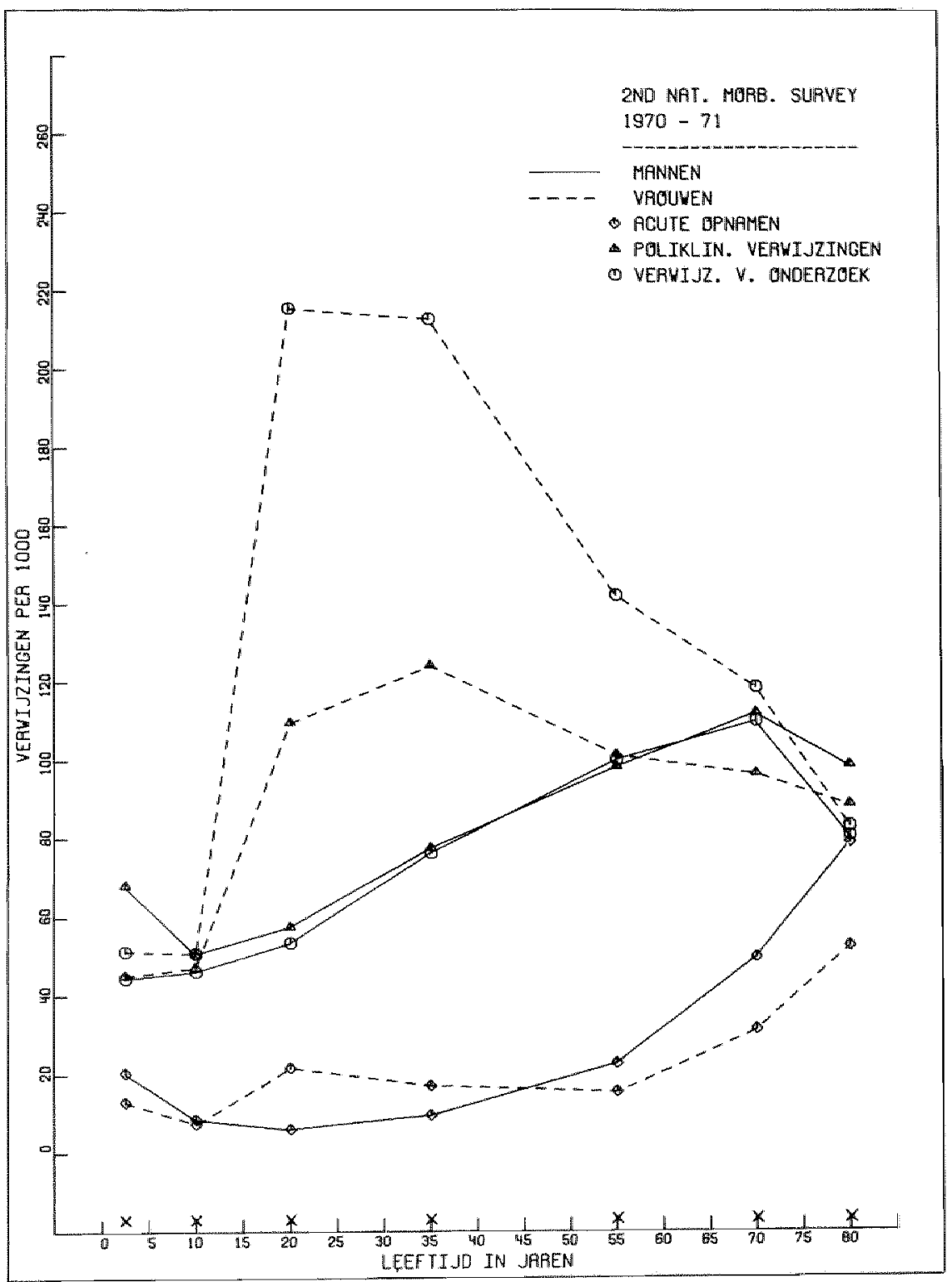


het op geaggregeerd niveau (woor de totale patientengroep) het huisbezoek een functie is van de leeftijd van de patient. Verschillen tussen mannen en vrouwenzijn er nauwelijks (iets meer (kraam?) visites bij vrouwen tussen de $15-44$ jaar). In figuur 3 treft men de aantallen verwijzingen per 1000 ingeschreven patiënten aan. Acute opnamen volgen de "ernst-curwe".

Voor mannen stijgen zowel verwijzingen voor onderzoek als poliklinische verwijzingen wan 5 tot 65 jaar. Voor de hoogste leeftijdscategorie zijn ze weer lager en benaderen ze het aantal acute opnamen. Voor vrouwen valt vooral de grote hoeveelheid verwijzingen voor onderzoek op in de vruchtbare leeftijd. Vergelijkt men deze cijfers met de door Posthuma (1976) gepresenteerde verwijsgegevens over alle in 1974 bij het Nijmeegse Ziekenfonds BAZ gedeclareerde verwijskaarten, dan is de overeenkomst met betrekking tot mannelijke verzekerden zo op het oog heel aardig zij het op een consequent lager niveau. Posthuma onderscheidt 3 categorieën: verwijzingen gepaard gaande met een opname in hetzelfde jaar; verwijzingen samengaand met een of meer herhaalkaarten en verwijzingen zonder opname of herhaalkaart. Men ziet (zie 10.4 en 10.5) bij mannelijke verzekerden een overeenkomst bij de opnamen en de verwijzingen-cum-herhaalkaarten. De cijfers voor wrouwelijke verzekerden lopen sterker uiteen. De overeenkomst tussen het verloop van thet totale Engelse verwijscijfer voor yrouwen en de Nederlandse verwijscijfers voor gynaccologie (Posthuma, 1976, 13, figuur 10.6) wettigen de conclusie dat in Engeland verwijzingen van vrouwen veel sterker bepaald worden door gynaecologie en verloskunde dan in Nederland. Het hogere percentage klinische en poliklinische bevallingen in het Verenigd Koninkrijk zal hier niet vreemd aan zijn.

\subsection{Analyse}

\subsubsection{Eerste contacten en terugbestelcontacten}

Onze vraagstelling is: heeft de huisarts invloed op de medische consumptie van zijn patiënten? Zijn factoren die men kan opvatten als aanbod-aspecten van de huisartspraktijk (praktijkgrootte, praktijkvorm) van invloed op respectievelijk het aantal eerste en terugbestelcontacten in de praktijkpopulatie?

Een tweede vraag is of er - afhankelijk van de situering van de praktijk tem opzichte van een ziekenhuis en het aanbod van klinische zijde - sprake is van substitutie tussen terugbestellen en verwijzen.

Gegeven de sterke invlloed van de samenstelling van praktijk naar leeftijd en geslacht op de consumptiegegevens, hebben we als afhankelijke variabelen telkens het verschil berekend tussen het aantal contacten dat men zou verwachten op grond van de verdeling van de praktijkbevolking naar leeftijd en geslacht, (berekend op grond van de in de vorige paragraaf vermdelde contactfrequenties per leeftijds/geslachtsgroep van alle praktijken tezamen), en het aantal dat feitelijk wordt aange- 
Figuar 10.4.: Verwijzingen naar klinische specialismen woor vrouwelijke verzekerden in 1974. Ziekenfonds BAZ, Nijmegen.

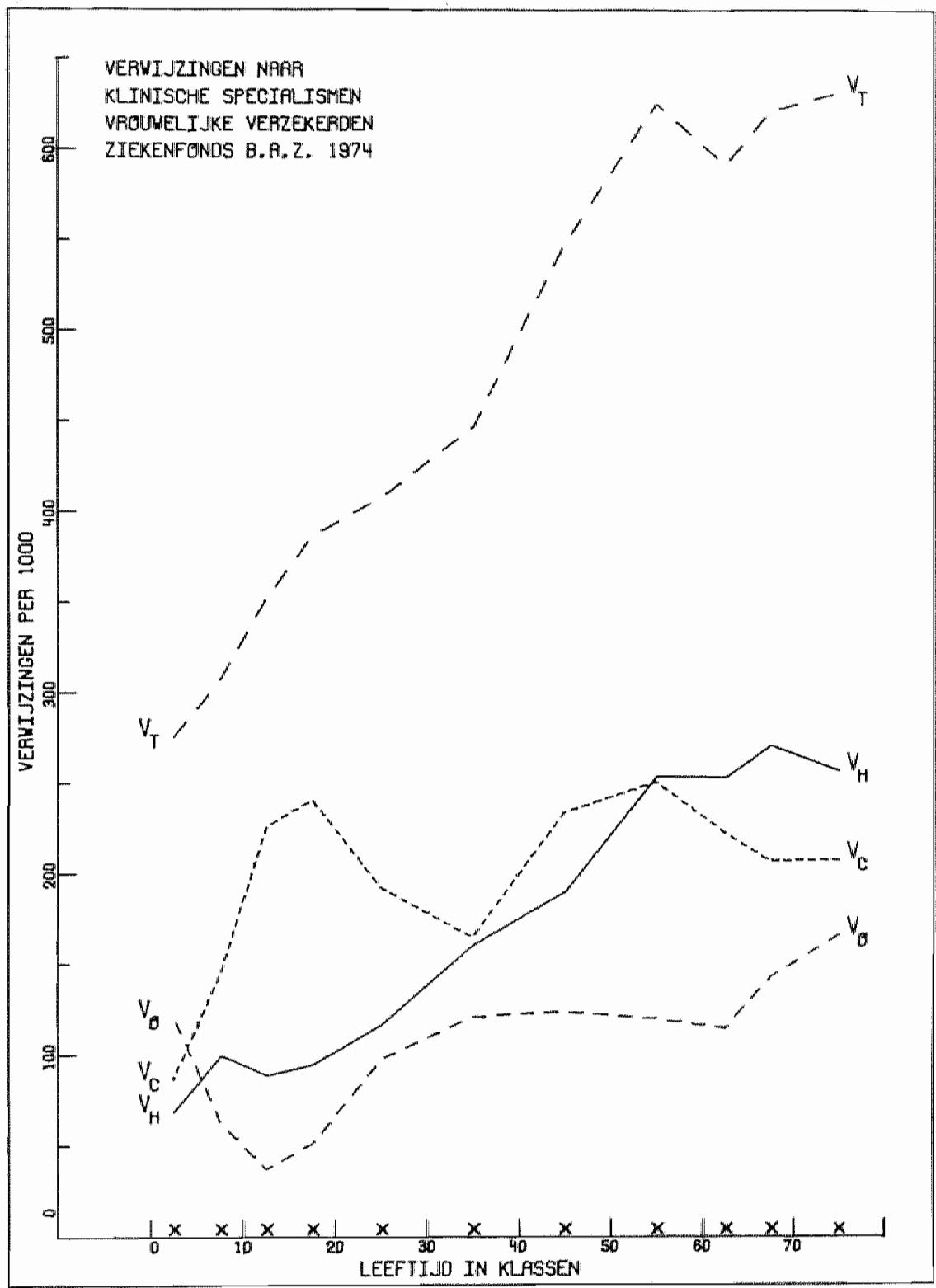


Figuur 10.5.: Verwijzingen naar klinische specialismen voor mannelijke verzekerden in 1974. Ziekenfonds BAZ, Nijnegen.

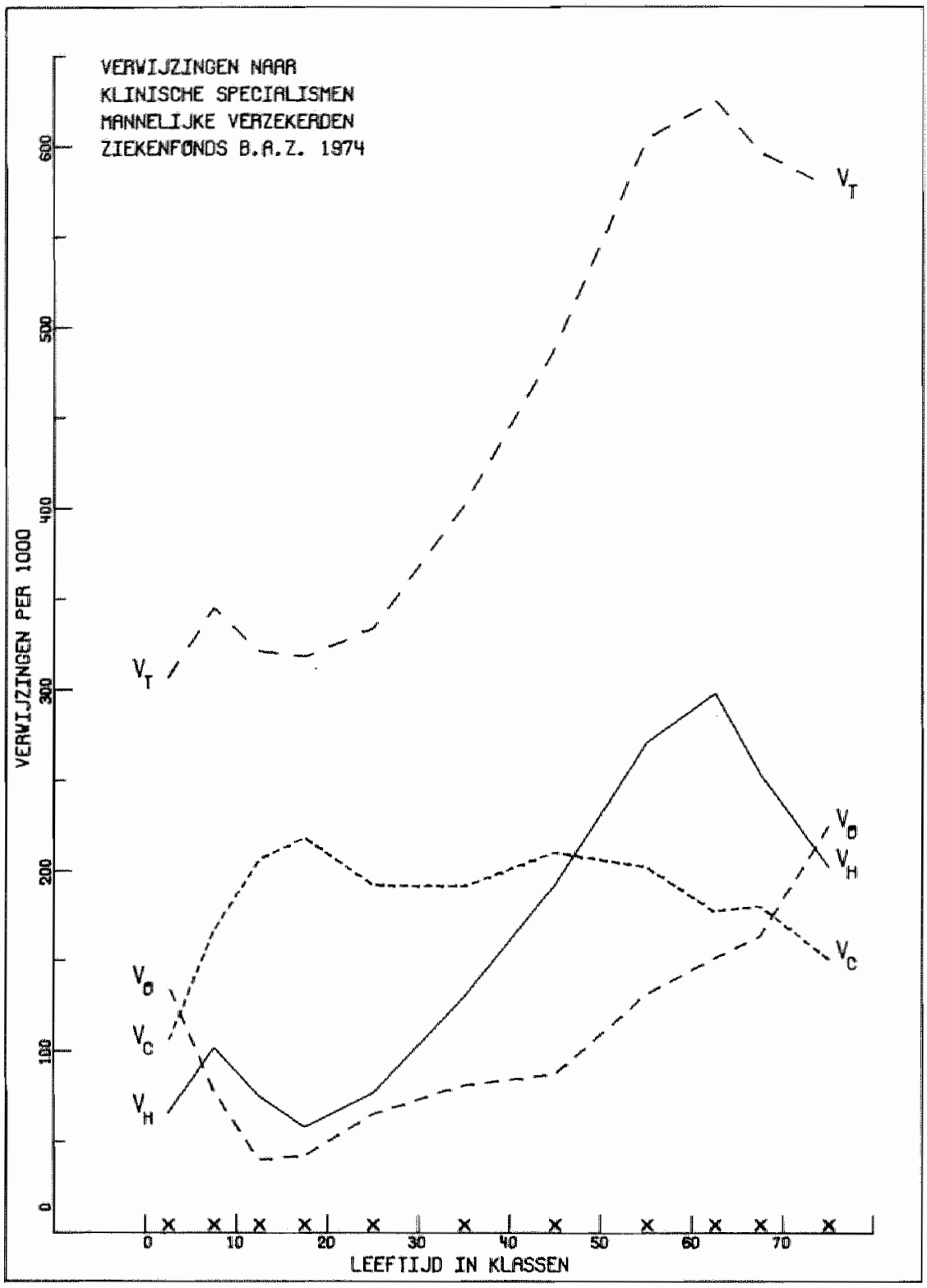


Figuur 10.6.: Verwijzingen naar chirurgische specialismen (inclusief gynaecologie) voor vrouwelijke verzekerden in 1974. Ziekenfonds BAZ, Nijmegen.

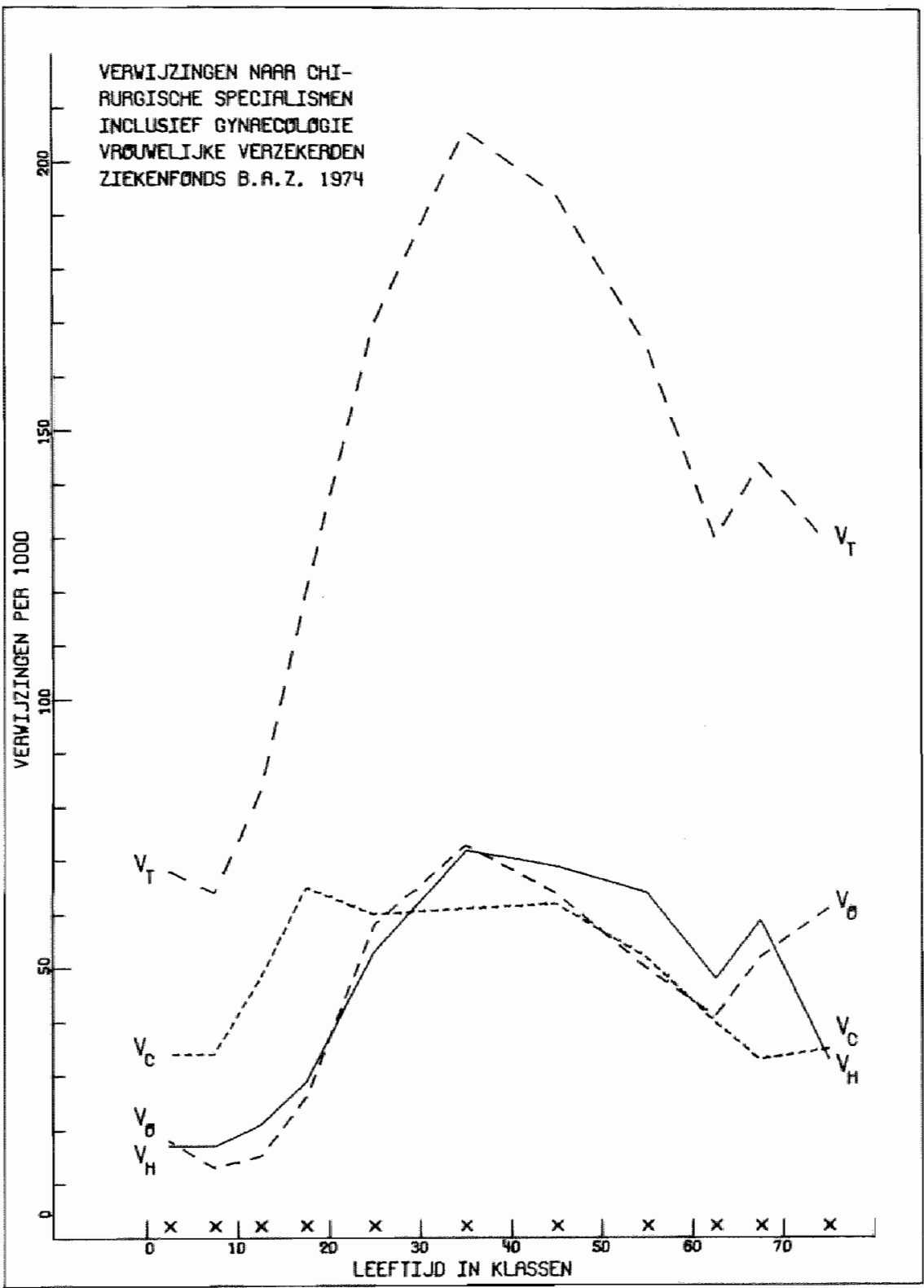


troffen. Als onafhankelijke variabelen hebben wij de beschikking over de 'list size'de grootte van de huisartspraktijk; het aantal artsen in de praktijk en twee indicaties van de ligging - namelijk het onderscheid stad/platteland en de afstand tot het dichtstbijzijnde ziekenhuis.

In eerste aanleg vonden wij geen verband tussen praktijkgrootte en het verschil tussen verwachte en aangetroffen aantallen eerste contacten, terugbestelcontacten en chronische aandoeningen (le contacten $r=.07$, terugbestell $r=-.14 n=60$ ). Nadere inspectie van de verbanden bracht aan het licht dat:

1. het verband versluierd werd door een niet ver wachte relatie tussen praktijkvorm en aantallen contacten (solisten bleken meer eerste contacten en terugbestelcontacten te noteren dan duo- en groepspraktijken èn hadden gemiddeld wat grotere praktijken) en

2. dat bij één arts dusdanig afwijkende waarden werden gevonden voor het aantal terugbestelcontacten ( 3 maal de standaarddeviatie) dat de correlatie tot niet significant van nul verschillend werd gereduceerd (zie bijlage $\mathrm{E}$, figuur 2).

Na verwijdering van deze praktijk en een afzonderlijke analyse voor solopraktijken en samenwerkende huisartsen bleken de verbanden heel goed interpretabel te zijn. In dit hoofdstuk zullen we de belangrijkste verbanden bivariaat laten zien, voor solisten en samenwerkende artsen en vervolgens regressieresultaten voor de gehele groep presenteren. (Figuur 10.7-10.8: solisten, pagina 123, figuur 10.9-10.10: samenwerkende artsen pagina 124).

\section{Commeniaar}

Praktijkgrootte blijkt het aantal contacten op initiatief van de patiënt noch in solopraktijken, noch in samenwerkingsverbanden te beïnvloeden maar het aantal terugbestelcontacten wel. Bij de solisten (figuur 10.8) ziet men dat een extreem kleine praktijk (de praktijk met 1468 zielen) er voor zorgt dat de relatie niet nog veel sterker is (correlatie zonder deze praktijk is -.72 ). In grote praktijken wordt dus minder terugbesteld dan men zou verwachten op grond van de leeftijds/geslachtsverdeling van de patiënten; in kleine praktijken daarentegen meer.

Het is annemelijk dat dezelfde werbanden in Nederland gevonden worden. Bekend was al (zie Posthuma en Van der Zee, 1978, 1980) dat huisartsen met grotere praktijken hun patiènten naar verhouding minder vaak zien. Weliswaar is de Nederlandse situatie complexer door de aanwezigheid van een groep per verrichting

Figuren 10.7-10.10: Grafische weergave van het verband tussen praktijkgrootte en het verschil tussen antal aangetroffen en op grond van de leeftijds/geslachisverdeling van de praktijkpopulatie verwachte aantal eerste respectievelijk terugbestelcontacten in 59 Engelse solo- en meermanspraktijken. 

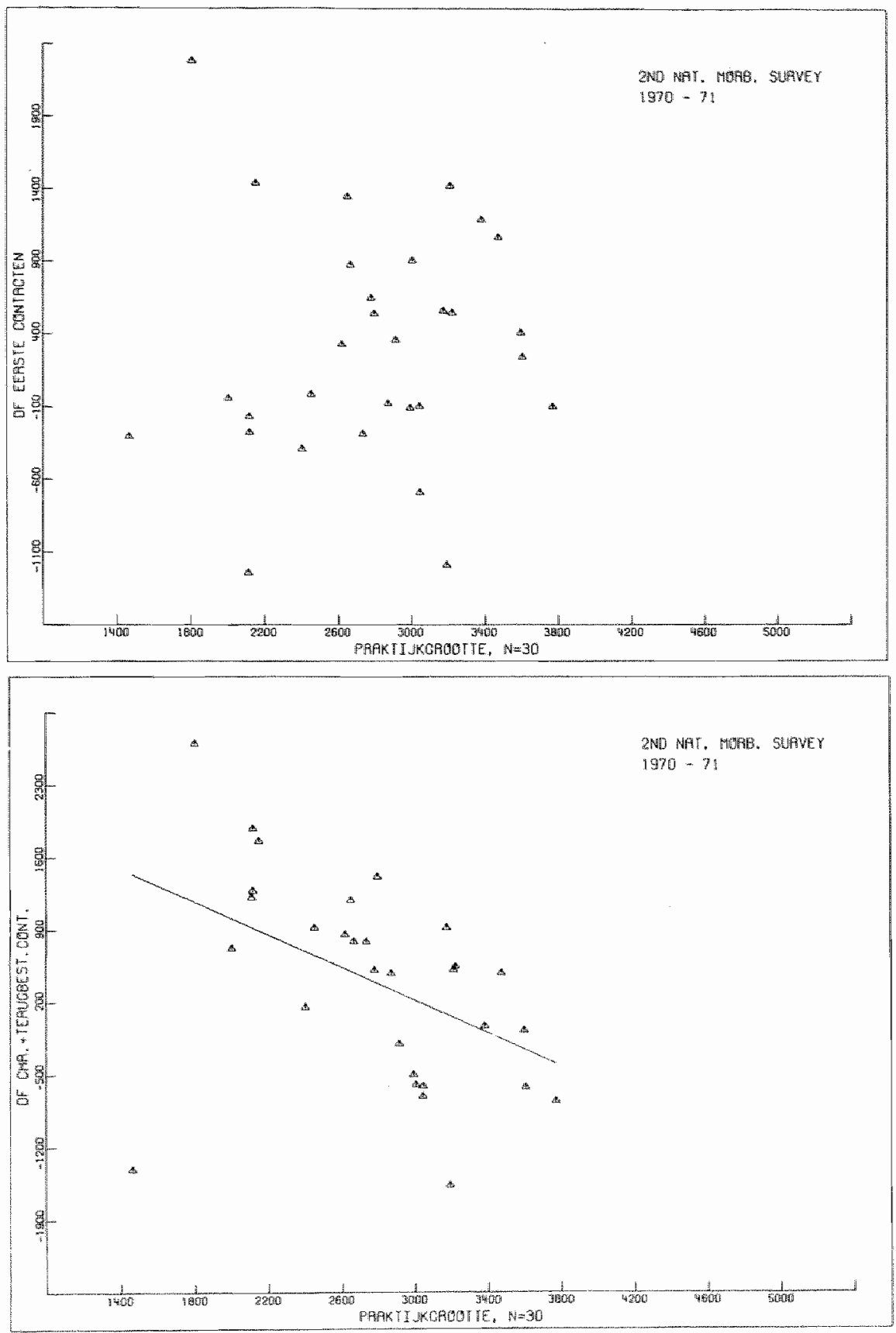

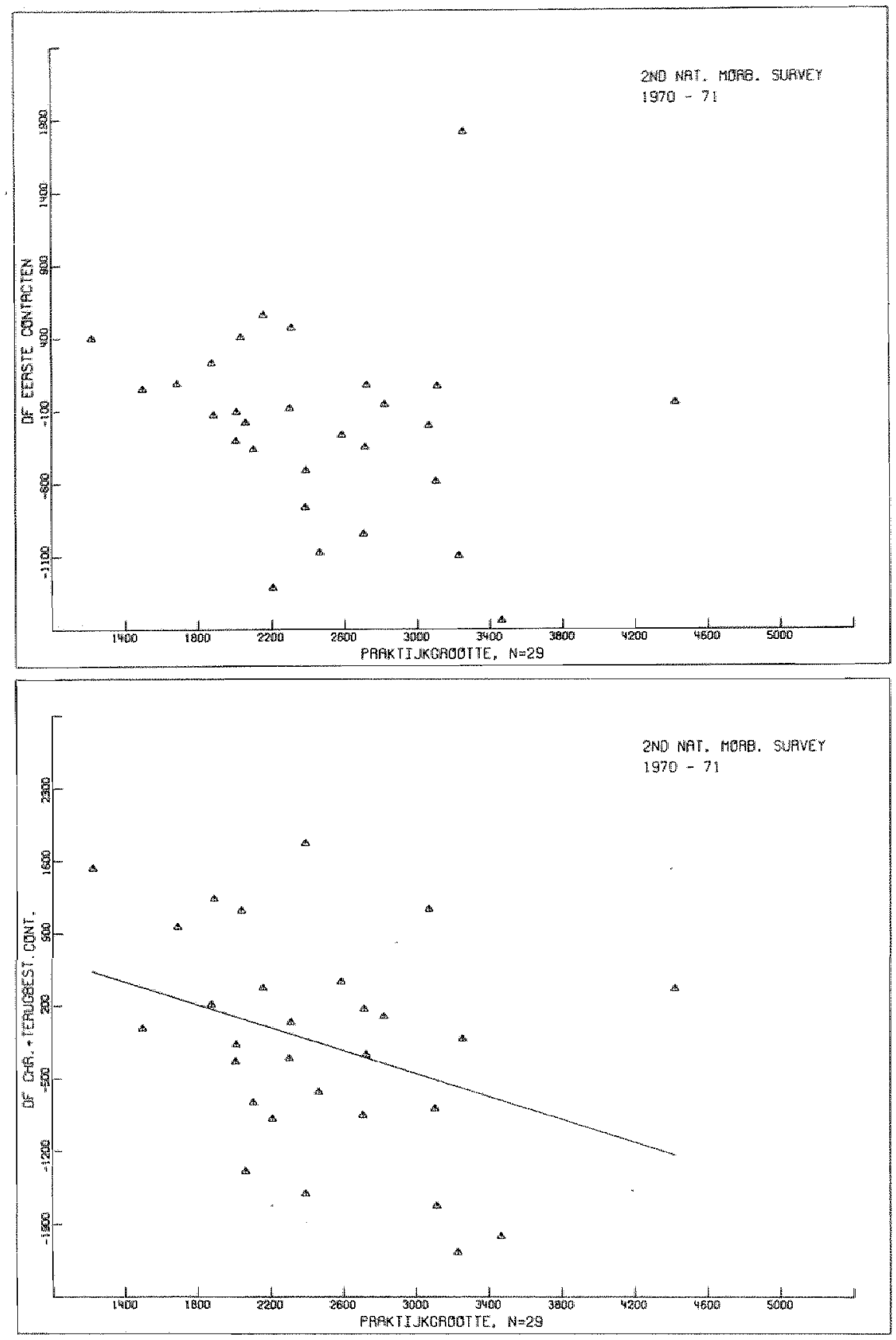

124 
Figuren 10.9 en 10.10: Samenwerkende artsen

Tabel 10.2.: Regressie-analyse, B-coefficienten en T-warden van praktijkgrootte, praktijkvorm en praktijklocatie met de verschillen tussen het angetroffen ancal le contacten, terugbestelcontacten en visites en hel aantal dat men op grond wan de leeftijds/geslachtsverdeling van de praktijk zou verwachten. T-waarden cursief bij p < 0.05. Bron: Gegevens Second National Morbidity Survey-Engeland/ Wales $1970 / 1971$.

\begin{tabular}{|c|c|c|c|c|c|c|c|}
\hline \multicolumn{8}{|c|}{ B-coefficientern en T-woraroen (tussen haken) } \\
\hline $\begin{array}{c}\text { gemiddelote } \\
\text { en } \\
\text { stardarad } \\
\text { deviatie } \\
\text { wan de al- } \\
\text { hankelijke } \\
\text { variabelen }\end{array}$ & $\begin{array}{l}\text { prakcijk- } \\
\text { grootto }\end{array}$ & $\begin{array}{l}\text { dummay } \\
\text { praktifs. } \\
\text { vorma } \\
1=\text { solo) }\end{array}$ & $\begin{array}{l}\text { dumbiny } \\
\text { praktijk- } \\
\text { locatie } \\
\text { (1= stady }\end{array}$ & 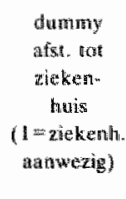 & $\begin{array}{l}\text { dummy } \\
\text { alst } 10 \text { a } \\
\text { zickery- } \\
\text { buts } \\
(1=2 \mathrm{H} \\
>15 \mathrm{~km})\end{array}$ & Consiante & $N=59$ \\
\hline 57.73 & -015 & 441.67 & .407 .20 & 6.5 .01 & 747.03 & -501.84 & .111 \\
\hline$(766.60)$ & $(09)$ & $(2.22)$ & $(1.51)$ & $(.24)$ & $(1.97)$ & $(1.12)$ & \\
\hline
\end{tabular}

\begin{tabular}{|c|c|c|c|c|c|c|c|c|}
\hline $\begin{array}{l}\text { DF eposoden } \\
\text { an teljagr } \\
=1 \text { contacterat }\end{array}$ & $\begin{array}{l}57.73 \\
(766.60)\end{array}$ & $\begin{array}{r}-015 \\
(09)\end{array}$ & $\begin{array}{l}441.67 \\
(2.22)\end{array}$ & $\begin{array}{l}407.20 \\
(1.51)\end{array}$ & $\begin{array}{l}6.5001 \\
(.24)\end{array}$ & $\begin{array}{l}747.03 \\
(1.97)\end{array}$ & $\begin{array}{l}-591.84 \\
(1.12)\end{array}$ & .111 \\
\hline $\begin{array}{l}\text { DF episoder } \\
\text { in jaat voor } \\
\text { geljar } \\
\text { \# chron.probl. }\end{array}$ & $\begin{array}{l}-6.57 \\
(288.23)\end{array}$ & $\begin{array}{l}-165 \\
(2.94)\end{array}$ & $\begin{array}{l}20.75 \\
(.21)\end{array}$ & $\begin{array}{l}147.89 \\
(1.51)\end{array}$ & $\begin{array}{l}20.94 \\
(.22)\end{array}$ & $\begin{array}{l}295.95 \\
2.141\end{array}$ & $\begin{array}{l}244.91 \\
(1.28)\end{array}$ & 168 \\
\hline $\begin{array}{l}\text { DF Teragbe- } \\
\text { stieteon- } \\
\text { tacten }\end{array}$ & $\begin{array}{l}129.05 \\
(921.39)\end{array}$ & $\begin{array}{l}-.518 \\
(2.64)\end{array}$ & $\begin{array}{l}73006 \\
(3.73)\end{array}$ & $\begin{array}{l}-65.38 \\
(.21)\end{array}$ & $\begin{array}{l}-183.32 \\
(.57)\end{array}$ & $\begin{array}{l}-342.50 \\
(.76)\end{array}$ & $\begin{array}{l}1348.50 \\
(2.17)\end{array}$ & .137 \\
\hline $\begin{array}{l}\text { DF rerugbe- } \\
\text { stel } \\
\text { chrontprobl. }\end{array}$ & $\begin{array}{l}125.42 \\
(1039.81)\end{array}$ & $\begin{array}{l}-.668 \\
(3.05)\end{array}$ & $\begin{array}{l}746.76 \\
(2.85)\end{array}$ & $\begin{array}{l}84.52 \\
(.24)\end{array}$ & $\begin{array}{l}-179.94 \\
(.50)\end{array}$ & $\begin{array}{l}-54.55 \\
(.11)\end{array}$ & $\begin{array}{l}1574.56 \\
(2.27)\end{array}$ & .156 \\
\hline $\mathrm{DF}$ visites & $\begin{array}{r}-17.35 \\
(463.4)\end{array}$ & $\begin{array}{l}-.677 \\
(.77)\end{array}$ & $\begin{array}{l}-43.96 \\
(.36)\end{array}$ & $\begin{array}{l}-442,38 \\
(27 l)\end{array}$ & $\begin{array}{l}99.18 \\
(.61)\end{array}$ & $\begin{array}{l}-72.77 \\
(.32)\end{array}$ & $\begin{array}{l}462.54 \\
(4.46)\end{array}$ & .108 \\
\hline
\end{tabular}

betalende patienten, maar dit heeft vermoedelijk alleen tot gevolg dat de relaties tussen praktijkgrootte en terugbestelcontacten voor ziekenfondsverzekerden nog sterker zijn den in het Engelse systeem van gezondheidszorg.

De vraag blijft natuurlijk wat daar nu weer de gevolgen van zijn, bijvoorbeeld in termen van substitutie tussen terugbestellen en verwizen, in termen van kwalitei: van de verleende zorg of in termen wan 'somatische fixalte' voor de patient, mar dit is een onderwerp voor verder onderzoek.

Wij zullen de resultaten voor de gehele groep (minus de spelbederver) in regresslevorm weergeven (tabel 10.2. \%. 
Zoals al is gezegd bij het commentaar op de grafische weergave van de bivariate rellatie tussen praktijkgrootte en de verschillende soorten contacten, beïnvloedt praktijkgrootte niet het verschil tussen het aantal feitelijk aangetroffen en het op grond van de verdeling van de praktijkbevolking naar leeftijd en geslacht verwachte aantal contacten op initiatief wan de patiënt, maar wel de verschillende vormen van terugbestelcontacten.

De locatie wan de praktijk (stad/platteland en afstand tot het ziekenhuis) heeft geen invloed op de aangetroffen verschillen in eerste- en terugbestelcontacten: op éen uitzondering na: als een praktijk meer dan 15 kilometer van een ziekenhuis is verwijderd, treft men meer contacten voor chronische problemen aan, dan men op grond van de verdeling van de praktijk naar leeftijd en geslacht zou verwachten. Bovendien zien we iets meer contacten op initiatief van de patiënt in deze categorie. Een aardig detail is nog, dat het verschil tussen het aantal aangetroffen en verwachte visites alleen beïnvloed wordt door de praktijklocatie. Op het platteland treft men meer visites aan dan men zou verwachten op grond wan de leeftijdsverdeling van de huisartsenpraktijk en in de stad minder. De omvang van de praktijk doet er niet toe. De beslissing consult/visite wordt door huisartsen blijkbaar niet gehanteerd om hun werkbelasting te reduceren. Ook is het niet zo dat in tweemans- en groepspraktijken de patiënt vaker gevraagd wordt op het spreekuur te komen zodat de huisarts geen huisbezoek hoeft af te leggen.

Wat betreft de praktijkworm vindt men in solopraktijken zowel meer contacten op initiatief van de patiënt als op initiatief van de huisarts dan men zou verwachten. Bij het formuleren van onze verwachtingen hebben wij voor een systeem als het Engelse (en het Nederlandse), waar artsen niet door middel van concentratie van mankracht en kapital schaaleffecten in het produceren van verrichtingen kumnen creëren, voorspeld dat een strakkere organisatie (afspraakspreekuur) wellicht het aantal eerste contacten zou doen afnemen; nièt het aantal terugbestelcontacten, omdat die juist langer van tevoren kunnen worden vastgelegd. Daarnaast voorspelden we dat de concentratie van spreekuurpunten bij samenwerkende huisartsen ook een verminderd aantal contacten met zich mee zou kunnen brengen.

We vinden bij deze artsen een geringer aantal contacten zowel op initiatief van de huisarts als van de patiênt. Bovendien weten we niet of alle meermanspraktijken afspraakspreekuren hanteren of wie van de solo-artsen zijn contacten op deze wijje reguleert. Toetsen kunnen we deze gedlachte dus niet. Het enige wat we wel kunnen doen is bezien of de verschillen tussen solo- en meermanspraktijken voor alle leeftijds/geslachtscategorieën gelden. Parkin (1979) stelt, zoals we hebben laten zien, dat voor werkende mannen de afstand woonhuis/adres huisartspraktijk niet van belang was.

Newhouse e.a. (1981) (de groep van de Rand corporation) vonden dat de hoogte van de eigen bijdrage van iemands verzekering voor doktersbezoek en ziekenhuis- 
opname wel de cijfers voor volwassenen beinvloeden, maar niet de medisthe consumptie van kinderen.

Aangezien afstand ook in zekere zin als kostenfactor moet worden beschouwd willen we bezien of de aangetroffen verschillen kleiner zijn of niet bestaan voor mannen van 15-64 jaar en voor kinderen. ${ }^{26}$ Is dat het geval dan is de concentratie van spreekuurpunten de vermoedelijke oorzaak van de verschillen. Blijven de verschillen staan, dan zal de oorzaak vermoedelijk in de richting van de, op dit moment niet verder toetsbare, organisatiestructuur moeten worden gezocht. In tabel 10.3 laten we het gemiddeld aantal contacten op initiatief van de patiènt per

Tabel 10.3.: Toetsing van het gemiddeld aantal (standaarddeviatie tussen haken) contacten op initiatief van de patient in solo-en meermanspraktijken.

Cursief bij $\mathrm{p}<0.05$.

(Bron: 2Nd National Morbidity Survey 1970/71, Engeland/Wales.)

\begin{tabular}{|c|c|c|c|c|c|c|}
\hline \multirow[b]{2}{*}{ leeftijd } & \multicolumn{3}{|c|}{$\begin{array}{l}\text { gerniddelden voor } \\
\text { mannen }\end{array}$} & \multicolumn{3}{|c|}{$\begin{array}{c}\text { gemiddelden voot } \\
\text { wrouwen }\end{array}$} \\
\hline & $\begin{array}{l}\text { solo } \\
\mathrm{n}=30\end{array}$ & $\begin{array}{l}\text { samenw. } \\
\mathrm{n}=29\end{array}$ & T-waarde & $\begin{array}{l}\text { solo } \\
\mathrm{n}=29\end{array}$ & $\begin{array}{l}\text { samenw. } \\
\mathrm{n}=30\end{array}$ & T-waarde \\
\hline 0.4 jaar & $\begin{array}{l}3.19 \\
(.94)\end{array}$ & $\begin{array}{l}2.77 \\
(.69)\end{array}$ & 1.96 & $\begin{array}{l}2.91 \\
(.80)\end{array}$ & $\begin{array}{l}2.53 \\
(.65)\end{array}$ & 2.03 \\
\hline 5-14 jaat & $\begin{array}{l}1.64 \\
(.37)\end{array}$ & $\begin{array}{l}1.31 \\
(.28)\end{array}$ & 3.87 & $\begin{array}{l}1.71 \\
(.37)\end{array}$ & $\begin{array}{l}11.34 \\
(.26)\end{array}$ & 4.44 \\
\hline 15-24 jaar & $\begin{array}{l}1.34 \\
(.42)\end{array}$ & $\begin{array}{l}1.13 \\
(.18)\end{array}$ & 2.41 & $\begin{array}{l}2.32 \\
(.4)\end{array}$ & $\begin{array}{l}2.10 \\
(.41)\end{array}$ & 1.91 \\
\hline $25-44$ jaar & $\begin{array}{l}1.26 \\
(.42)\end{array}$ & $\begin{array}{l}1.14 \\
(.28)\end{array}$ & 1.31 & $\begin{array}{l}2.10 \\
(.51)\end{array}$ & $\begin{array}{l}1.99 \\
(.34)\end{array}$ & .90 \\
\hline $45 \times 64$ jaar & $\begin{array}{l}1.26 \\
(.32)\end{array}$ & $\begin{array}{l}1.17 \\
(.20)\end{array}$ & 1.29 & $\begin{array}{l}1.60 \\
(.30)\end{array}$ & $\begin{array}{l}1.49 \\
(.28)\end{array}$ & 1.45 \\
\hline $65-74$ jaar & $\begin{array}{l}1.44 \\
(.33)\end{array}$ & $\begin{array}{l}1.26 \\
(.26)\end{array}$ & 2.31 & $\begin{array}{l}1.48 \\
(.30)\end{array}$ & $\begin{array}{l}1.38 \\
(.29)\end{array}$ & 1.35 \\
\hline 75 jaar e.o. & $\begin{array}{l}1.54 \\
(.44)\end{array}$ & $\begin{array}{l}1.39 \\
(.32)\end{array}$ & 1.59 & $\begin{array}{l}1.47 \\
(.42)\end{array}$ & $\begin{array}{l}1.35 \\
(.32)\end{array}$ & 1.20 \\
\hline alle Ift. & $\begin{array}{l}1.49 \\
(.38)\end{array}$ & $\begin{array}{l}1.32 \\
(.22)\end{array}$ & 2.11 & $\begin{array}{l}1.90 \\
(.36)\end{array}$ & $\begin{array}{l}1.73 \\
(.30)\end{array}$ & 1.94 \\
\hline
\end{tabular}


leeftijdsgroep bij mannen en vrouwen zien voor solopraktijken en meermanspraktijken. De gemiddelden zijn getoetst met Student's T; de waarde van deze toetsingsgrootheid en de kans op een op toeval gebaseerd verschil staat telkens in de derde kolom. Wij hebben gekozen voor het aantal contacten op initiatief van de patiënt ${ }_{\text {}}$ omdat we dan met een simpeler analyse kunnen volstaan; de gemiddeld wat grotere praktijken van solisten beinvloeden deze contacten niet. ${ }^{27}$

\section{Commenraar}

Voor mannen van 25 tot 64 jaar vinden we geen (significant) werschil in aantallen contacten tussen solistische en meermanspraktijken. Men zou zeggen dat onze werwachting met betrekking tot de locatie-factor bevestigd was, als we niet bij wrouwen in dezelfde leeftijdscategorie eveneens geen verschil hadden aangetroffen en bij kinderen (van beide sexen) wel.

Eerder kan men stellen dat de belangrijkste verschillen zijn aan te treffen in de categorieën patiënten, die de minste zorg nodig hebben. Dit komt ook overeen met het in tabel 10.2. gevonden resultaat, dat bij chronische aandoeningen geen verschil tussen solisten en samenwerkende thuisartsen gevonden wordt. De praktijkorganisatie remt blijkbaar de iets minder urgente en lichtere problematiek. Dit komt overeen met de bevindingen van Neven (1980) die in zijn studie over 'uitstel gedrag' vond, dat jongere patiënten in associatiepraktijken meer tot uitstel geneigd waren (Neven, 1980, 86).

\subsubsection{Terugbestellem en verwijzen. Substitufie in de Engelse gezondheidszorg?} Het vraagteken in de kop wan deze paragraaf wijst op enige twijfel onzerzijds. Wellicht is de substitutie terugbestellen/verwijzen typerend voor een op verrichtingen gegrond systeem van gezondheidszorg, zoals wij in Nederland voor de specialistische gezondheidszorg kennen.

Toch zullen wij de rest van ons model ook moeten toetsen, al was het alleen maar omdat ook het ontbreken van resultaat een belangwekkende uitkomst is. Nu we in de vorige paragraaf hebben laten zien dat 'terugbestellen' een functie is van prak-

Figuur 10.11.: Schematische voorstelling van een substitutiemodel voor terugbestellen en verwijzen in de huisartspraktijk.

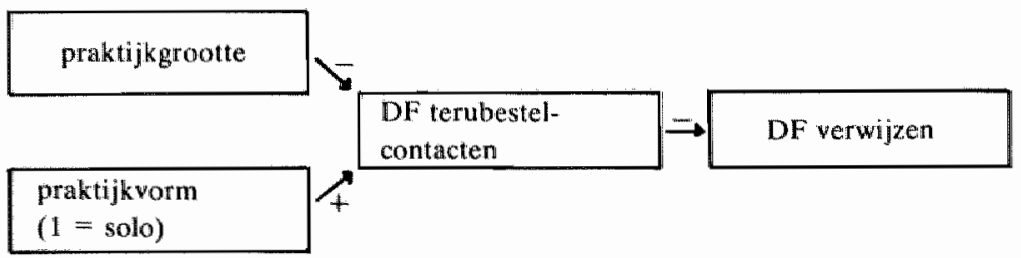


tijkgrootte en praktijkvorm en dat 'eerste contacten' niet door de omvang wan de huisartspraktijk worden beïnvloed, zouden we het volgende substitutiemodel kunnen schetsen.

Formeel betreft het hier een schatting in twee stadia; eerst verklaren we terugbestellen (gecorrigeerd woor de samenstelling van de prak tijk naar leeftijd en geslacht) uit praktijkgrootte en praktijkvorm. Het aldus geschatte verschil beinvloedt op zijn beurt weer het aantal verwijzingen. (Ook weer na correctie van leeftijd/geslacht). Dit model is op één belangrijk aspect na onvolledig; het gaat voorbij aan de inwloed die we denken dat afstand tot en omvang van tweedelijnswoorzieningen op de verwijsfrequenties zullen hebben.

Daarom moeten we ons model als volgt modificeren:

Figuur 10.12.: Schematische woorstelling van een substitutiemodel voor terugbestellen en verwijzen in de huisartspraktijk waarbij rekening gehouden is met aanbodfactorem in de $2 \mathrm{e}$ lijm.

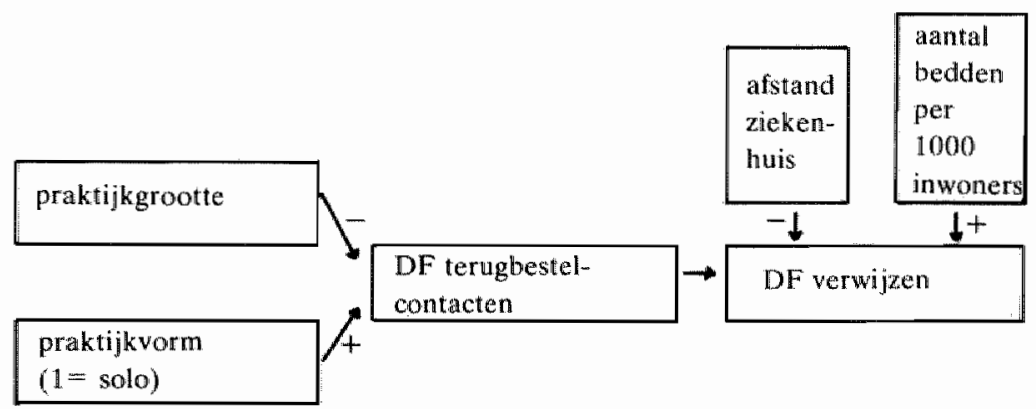

Bovendien zijn in het 2 nd NMS de verwijzingen als volgt opgesplitst:

1. verwijzingen voor acute opname

2. poliklinische verwijzingen

3. verwijzingen voor onderzoek.

Wij verwachten dat acure opnamen buiten het substitutiemodel vallen. Wellicht dat afstand tot ziekenhuis en het relatieve aantal bedden in de regio van invloed zullen zijn, maar dat is dan ook het enige. Wij verwachten niet dat het aantal terugbestelcontacten in de praktijk lyet aantal acute opnamen beinvloedt. Voor verwijzingenvoor-onderzoek geldt eveneens dat we geen substitutie-effect verwachten: de huisarts krijgt de patiënt immers met de uitslag van het onderzoek weer terug. In dit (primitieve) model is ook geen maat opgenomen voor de ter beschikking staande onderzoekscapaciteit en is het niet bekend waarheen de patiënt met zo'n verwijzing-voor-onderzoek wordt werwezen.

Wij verwachten dat het in 10.12 geformuleerde model opgaat voor poliklinische 
verwijzingen; woor acute opnamen verwaehten we alleen een effect van de afstand en de omvang van de voorzieningen en wat betreft de verwijzingen voor onderzoek beschikken we over te weinig achtergrondgegevens om verwachtingen te kunnen toetsen.

Een handicap in onze analyse is het tot op heden ontbreken van een goede operationalisering van de factoren die het aanbod aan klinische voorzieningen indiceren. Wij weten alleen of de praktijk een stads- of een plattelandspraktijk is en de afstand tot het dichtstbijzijnde algemeen ziekenhuis in ruwe categorieën.

Het te toetsen model luidt als volgt:

Figuur 10.13, Schematische voorstelling van het in feite te toetsen substitutiemodel voor terugbestellen en verwijzen in de huisartspraktijk.

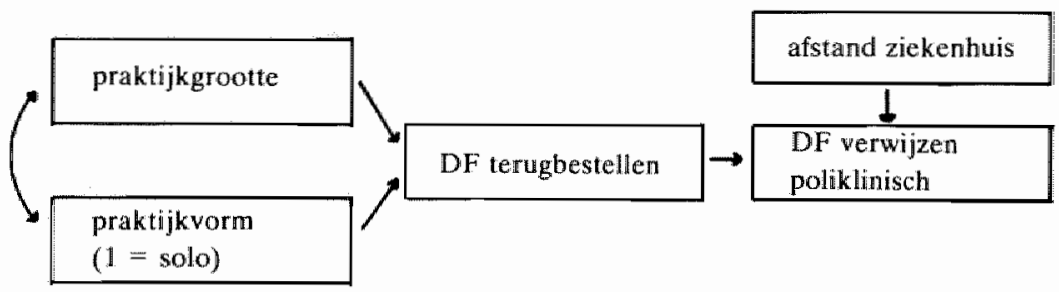

Wij verwachten een significant negatief verband tussen het in een eerste stadium geschatte verschil tussen het aangetroffen en het op grond van de leeftijds/ geslachtsindeling van de praktijk verwachte aantal terugbestelcontacten t: het verschil tussen het aantal aangetroffen en verwachte poliklinische verwijzingen. Bovendien verwachten we hogere verwijscijfers in stadspraktijken.

Voor acute opnamen verwachten we geen significante relatie met terugbestellen; alleen meer opnamen in de stad.

A Is operationalisatie van terugbestelcontacten nemen we in deze voorlopige versie het aantall terugbestelcontacten plus het aantal chronische aandoeningen.

De notatie woor de verschillende variabelen luidt als volgt. We definiëren 4 afhankelijke variabelen:

DF contacten initiatief huisarts

DF poliklinische verwijzingen

DF acute opnamen

DF verwijzingen onderzoek

en 5 gepredetermineerde variabelen:

praktijkgrootte

praktijkvorm

praktijklocatie

$$
\begin{aligned}
& (\text { DFCih }):=y_{1} \\
& \left(\text { DFVpo }:=y_{2}\right. \\
& (\text { DFVop }):=y_{3} \\
& (\text { DFVon }):=y_{4}
\end{aligned}
$$

$(\mathrm{PRAK}):=x_{1}$

$(\mathrm{SOLO}):=x_{2}$

$(\mathrm{STAD}):=\mathrm{x}_{3}$ 
ziekenhuis in gem.

ziekenhuis op meer dan $15 \mathrm{~km}$

van plaats $\left(\right.$ AFNUL): $=x_{4}$

$(\mathrm{AF} 15): \quad=x_{5}$

We onderstellen $y_{1}$ (DFCih) afhankelijk van $x_{1}, x_{2}, x_{3}, x_{4}$ en $x_{5}$

$y_{2}$ (DFVpo) afhankelijk van $y_{1}$ en $x_{4}$ en $x_{5}$

$y_{3}$ (DFVop) afhankelijk van $x_{4}$ en $x_{5}$

$y_{4}$ (DFVon) afhankelijk van $y_{1}, x_{4}$ en $x_{5}$

dat wil zeggen:

$\mathrm{y}_{1}=\mathrm{f}_{1}\left(\mathrm{x}_{1}, \mathrm{x}_{2}, \mathrm{x}_{3}, \mathrm{x}_{4}, \mathrm{x}_{5}\right)+\varepsilon_{1}$

$y_{2}=f_{2}\left(\hat{y}_{1}, x_{4}, x_{5}\right)+\varepsilon_{2}$

$y_{3}=f_{3}\left(x_{4}, x_{5}\right)+\varepsilon_{3}$

$y_{4}=f_{4}\left(\hat{y}_{1}, x_{4}, x_{5}\right)+\varepsilon_{4} \quad\left(\varepsilon_{i}(i=1, \ldots, 4)\right.$ zijn verstoringstermen $)$

In lineaire specificatie luidt dit:

$y_{1}=b_{10}+b_{11} x_{1}+b_{12} x_{2}+b_{13} x_{3}+b_{14} x_{4}+b_{15} x_{5}+\varepsilon_{11}$

$y_{2}=b_{20}+b_{24} x_{4}+b_{25} x_{5}+b_{26} \hat{y}_{1}+c_{2}$

$y_{3}=b_{30}+b_{34 x_{4}}+b_{35} x_{5}+\varepsilon_{3}$

$y_{4}=b_{40}+b_{44} x_{4}+b_{45} x_{5}+b_{46} \hat{y}_{1}+\varepsilon_{4}$

De geschatte waarde voor $y_{1}$ (DFCih) valt te berekenen uit tabel 10.2. De resultaten van düt tweede stadium vindt men in tabell 10.4.

Tabel 10.4.: Schattingsresultaten, 2 stadia schatting verwijscijfers $2 \mathrm{Nd}$ Nat. Morbidity Survey 1970, 71 B-coëfficiënten T-waarden (tussen haken en cursief bij $\mathrm{p}<05$ )

\begin{tabular}{|c|c|c|c|c|c|}
\hline & $\widehat{\mathrm{DFCih}}$ & AFnull & AF15 & Const. & $\overline{\mathrm{R}}^{2}(\mathrm{~N}=59)$ \\
\hline DFVop & $\begin{array}{l}.013 \\
(1.94)\end{array}$ & $\begin{array}{l}14.23 \\
(1.66)\end{array}$ & $\begin{array}{l}29.45 \\
(2.78)\end{array}$ & $\begin{array}{l}-12.40 \\
(1.60)\end{array}$ & .17 \\
\hline DFVpo & $\begin{array}{l}.024 \\
(.73)\end{array}$ & $\begin{array}{l}20.55 \\
(.48)\end{array}$ & $\begin{array}{l}84.49 \\
(1.60)\end{array}$ & $\begin{array}{l}-17.09 \\
(.44)\end{array}$ & .03 \\
\hline DFVon & $\begin{array}{l}.054 \\
(1.11)\end{array}$ & $\begin{array}{l}161.35 \\
(2.49)\end{array}$ & $\begin{array}{l}197.55 \\
(2.46)\end{array}$ & $\begin{array}{l}-142.85 \\
(2.44)\end{array}$ & .10 \\
\hline
\end{tabular}

\section{Commentaar}

Geen van onze verwachtingen kan de toets doorstaan.

De grootste afwijking vertonen de resultaten voor acute opnamen: We vinden een 
(bijna op $5 \%$ significante) positieve in plaats van de verwachte negatieve relatie tussen terugbestellen en verwijzen en bovendien treffen we meer ziekenhuisopnamen aan naarmate een huisartspraktijk verder van een ziekenhuis vandaan ligt. Voor dat laatste hadden we gewaarschuwd kunnen zijn. In het al eerder geciteerde rapport van Hicks $(1976,171)$ vermeldt hij zonder enig commentaar dat vooral in de regio's 'North, Yorkshire and Humberside, North-West' de verwijzingen op bet platteland hoger waren dan in de stad. In de rest van het land waren de stedelijke verwijscijfers hoger (Hicks, 1976, 171-76).

Wat betreft de verwijzingen voor onderzoek winden we ten opzichte van praktijken die tussen die 1 en $15 \mathrm{~km}$ van een ziekenhuis liggen zowel hogere cijfers in praktijken gevestigd in een plaats met een ziekenhuis als ook voor praktijken gevestigd op meer dan $15 \mathrm{~km}$ afstand van een ziekenhuis. De poliklinische verwijzingen laten zich geheel niet met dit model verklaren.

Er zijn nu twee dingen mogelijk: of de situatie is nu eenmaal zo in Engeland, hetgeen betekent dat de strikte regulering van de tweedelijnszorg en een dienstwerband voor specialisten de 'zuigkracht' uit de tweede lijn tot nul reduceert, òf onze redenering deugt niet. Het eerste zou bijvoorbeeld te maken kunnen hebben met het absoluut gezien lage niveau van het aantal werwijzingen. Als men de verwijzingen voor onderzoek (clie niet zonder meer een reductie van de werkzaamheden tengevolge zullen hebben) buiten beschouwing laat dan volgt uit de berekeningen op pag. 114 dat niet meer dan $\mathbb{1}$ op de 25 a 30 contacten tot een verwijzing leidt. Niet meer dan én per dag.

Het kan ook zijn dat we de substitutierelatie tussen terugbestellen en verwijzen niet goed hebben vorm gegeven, maar het splitsen van de terugbestelcontacten in 'chronische aandoeningen' en 'herhaalcontacten' noch het apart bezien van de resultaten voor mannen en vrouwen levert andere conclusies op. Voorlopig houden we het erop dat de substitutie terugbestellen/verwijzen eerder typerend is voor de Nederlandse gezondheidszorg dan voor de strikt gesloten Engelse vorm en wellicht voor het geheel open Belgische systeem (in België geldt namelijk nier dat de toegang tot de specialist via de huisarts is gereguleerd). Fleming en Maes (1980) vonden namelijk nauwelijks verschillen in het aantal verwijzingen per 1000 contacten tussen twee groepen Engelse en Belgische huisartsen (resp. 42.4 en 38.5- hetgeen overigens weer wat hoger is dan het getal uit de 2 Nd NMS (3.4.6), maar daarvoor kan de 'trend” verant woordelijk zijn). Systematische internationale vergelijking kan hier inzicht bieden, mar dat is een onderwerp apart.

Men zou overigens, gewend aan de Nederlandse situatie waar 'afstand tot het ziekenhuis' een belangrijk deel van de fluctuaties in verwijscijfers verklaart, bijna vergeten, dat het een teken van efficiënte distributie, en dus een te prijzen zaak is, als een factor als 'afstand' verwijscijfers niet beïnvloedt. Politiek gesproken, kan men tevreden zijn als een dergelijk resultaat wordt aangetroffen. 


\subsection{Samenvatting}

Het ontbreken van praktijkstudies op voldoende grote schaal in Nederland heeft ons doen uitwijken naar de Engelse gezondheidszorg, waar de huisarts een min of meer met de Nederlandse situatie vergelijkbare positie inneemt.

Het in $1970 / 71$ gehouden Tweede Nationale Morbiditeits Onderzoek uitgewoerd in 60 huisartspraktijken geeft ons de mogelijkheid het verband te onderzoeken tussen het aantal contacten op initiatief van respectievelijk huisarts en patiënt en de omvang, de vorm en de locatie van de praktijk.

Bovendien kunnen we onderzoeken (als we weten hoever de praktijken van het dichtstbijzijnde algemeen ziekenhuis verwijderd liggen) in boeverre er sprake is van een verband tussen het aantal (terugbestel)contacten in de huisartspraktijk en het aantal door de huisarts uitgeschreven verwijzingen.

\section{Eerste contacten en terugbestelcontacten}

Gezien de sterke relatie tussen het aantal contacten in de huisartspraktijk en de verdeling van de praktijkbevolking naar leeftijd en geslacht, hebben we de invloed. daarvan uitgeschakeld door telkens uit te gaan van het verschil tussen het aantal contacten dat men zou verwachten op grond van de verdeling van de praktijk naar leeftijd en geslacht (dit verwachte getal is weer berekend door uit te gaan van de contactfrequenties per leeftijds/geslachtsgroep voor alle praktijken tezamen) en het aantal dat men in feite aantreft. In eerste instantie vonden we geen verband tussen praktijkgrootte en het aantal op deze wijze gecorrigeerde contacten op initiatief van de patiënt; evenmin met het aantal contacten op initiatief van de huisarts.

Nadere inspectie van het materiaal bracht aan het licht, dat dit inderdaad klopte voor de contacten op initiatief van de patiënt, maar dat bij de terugbestelcontacten er wel degelijk sprake was van een verband; dit werd echter versluierd door twee dingen: le bleek één van de praktijken dusdanig afwijkende waarden te vertonen, dat de correlatie op zichzelf al ernstig werd verstoord, 2e bleken solistische huisart. sen èn consequent wat meer contacten te rapporten èn een wat grotere praktijk te hebben dan samenwerkende huisartsen.

Bekeken we de resultaten voor solistische en samenwerkende huisartsen afzonderlijk dan vonden we een duidelijk verband tussen praktijkgrootte en het verschil tussen het aantal verwachte en aangetroffen contacten op initiatief van de huisarts. Contacten op initiatief van de patiënt werden niet door de omvang van de praktijk beïnvloed.

Een nadere analyse van de verschillen in het aantal contacten per patiënt voor samenwerkende en solistische huisartsen, bracht aan het licht dat deze verschillen vooral aangetroffen werden bij naar verhouding 'gezonde' leeftijds- en geslachtsgroepen: vrouwen van 0-15 jaar en mannen van 5-24 jaar. 
Verwijzingen

De analyse van de verwijscijfers lewerde een ander resultaat op dan verwacht. Verwijzingen vanwege een opname in een ziekenhuis bleken ten eerste waker plaats te vinden naarmate de praktijk verder van een algemeen ziekenhuis was gelegen en ten tweede ook nog vaker plaats te vinden naarmate we in de praktijk meer terugbestelcontacten aantroffen dar we verwachten.

Poliklinische verwijzingen konden we in het geheel niet verklaren en voor verwijzingen ten behoeve van onderzoek gold, dat zowel in het geval dat de praktijk gevestigd was in een plaats met een algemeen ziekenhuis en in het geval dat daartussen meer dan $15 \mathrm{~km}$ lag, mér verwijzingen voor onderzoek werden gevonden dan in de tussenliggende categorieèn.

Het is heel goed mogelijk, dat de veel strakkere manier waarop in Engeland de tweedelijnszorg is opgezet (specialisten in loondienst, weinig bedden per capita) ervoor gezorgd heeft dat we geen substitutie vinden.

Als dat zo zou zijn, dat wil zeggen als er inderdaad geen 'afstandseffect' te vinden is, dan mag men de Engelse gezondheidszorg gelukwensen met een efficiënte distributie van kostbare en schaarse voorzieningen in de tweede lijn van de gezondheidszorg. 


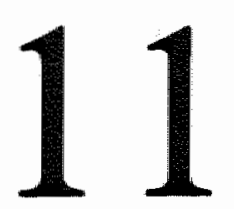

\section{Resultaten 3: Doktersbezoek in het Leef Situatie Onderzoek 1977}

\subsection{Inleiding}

Hoewel we in de vorige hoofdstukken nogal wat kanttekeningen hebben gemaakt bij de bruikbaarheid van gegevens uit bevolkingsenquêtes voor het verklaren van de vraag naar diensten van de huisarts, willen wij toch de lezer die resultaten van een dergelijke excercitie niet onthouden. Het nut erwan is beperkt; de actualiteit gering, al was het alleen maar omdat onlangs met hetzelfde materiaal een soortgelijke analyse is uitgevoerd en gepubliceerd ( Van Vliet en Van de Ven, 1982). ${ }^{2 B}$ Wij zijn echter wel nieuwsgierig naar de uiteindelijke relatie tussen klachten en doktersbezoek, nu we daarover zulke expliciete verwachtingen hebben geformuleerd.

Wij hebben bij onze analyse enigszins te kampen met de lage proportie verklaarde variantie in het klachtenmodel Wij kunnen niet 'doorschatten'. Van de lijst met lichamelijke klachten (de VOEG) werd in ons model (zie hoofdstuk 6) ruim $10 \%$ van de variantie verklaard (tabel 6.6.). Als we nu met een in het tweede stadium geschatte VOEG-score nog eens zouden proberen de contacten met de huisarts te verklaren blijft er niets meer te schatten over. In feite beginnen we cle presentatie van de resultaten alsof het eerste deel van dit verhaal niet geschreven zou zijn: wij schatten de kans op een bezoek aan of van de huisarts in één analyse.

Een tweede handicap bij de analyse van de gegevens uit het LSO77 is gelegen in het ontbreken wan factoren aan de aanbodzijde. We weten niet hoe groot of hoe druk de praktijk van de huisarts van de respondent is. We weten wel uit welke gemeente de respondent afkomstig is, zodat we op geaggregeerd niveau een voor die gemeente geldende waarde aan de respondent kunnen toekennen. We volgen hiermee dezelfde werkwijze als Van Vliet en Van de Ven (1982). 
De indeling van hoofdstuk 11 is als volgt: eerst volgt een beschrijving van de ten behoeve van dit gedeelte aan de analyse toegevoegde variabelen (paragraaf 11.2); vervolgens proberen we de frequentie van het contact met de huisarts te verklaren en tenslotte zullen we de relatie tussen ' $k$ lachten' en 'doktersbezoek' nog eens aan ean nadere analyse onderwerpen.

\subsection{Verantwoording van de gebruikte gegevens}

In deel I staan de variabelen die gebruikt zijn in het klachtenmodel reeds uitvoerig beschreven. Wij beperken ons hier tot de variabelen die nieuwe zijn in de analyse.

\section{Afhankelijke variabelen.}

- bezoek aan of van de huisarts in 3 maanden (ja/neen)

- aantal bezoeken aan of van de huisarts.

Deze twee gegevens zijn vrijwel ongewijzigd overgenomen. ${ }^{29}$ In de analyse is, gezien de lange 'staart' van de verdeling en de gevoeligheid van de correlatie-analyse voor extreme waarden een worteltransformatie toegepast (evenals we bij de VOEG hebben gedaan).

\section{Vraagyariabelen buiten het klachtenmodel}

- vrouwen in de vruchtbare leeftijd - grotere kans op contact met de huisarts vanwege anticonceptie en zwangerschap - dummy variabele met de waarde 1 voor viouwen van 15-45 jaar

- wijze van verzekering tegen ziektekosten - variabele met waarde 1. - indien particulier verzekerd ${ }^{30}$

- acuut ziek 1 - minder dan een week thuis geweest wegens ziekte in 3 manden

- acuut ziek 2 - éen tot twee weken thuis geweest wegens ziekte.

Aangezien de onderste leeftijdsgrens van de respondenten in het LSO 15 jaar is, is hetgeen wij in paragraaf 9.2 .1 gesteld hebben over klachten en doktersbezoek van kinderen niet van toepassing in de hierwolgende analyse.

\section{Aanbodgegevens}

In het Leef Situatie Onderzoek zijn gegevens over de aanbodzijde niet gemeten. Wij weten dus niet hoe groot of hoe druk de praktijk van iemands huisarts is (het is overigens de vraag of een patiënt enig idee heeft van de grootte van de praktijk) of hoe ver iemand nu precies van een ziekenhuis vandaan woont.

Wèl is bekend in welke gemeente de respondent woonachtig is. Wij bebben daarom de aanbodvariabelen berekend voor de gehele woongemeente van de respondent en de berekende waarden aan alle respondenten in die gemeente toegekend.

De volgende variabelen zijn berekend: 
1. het aantal huisartsen per 1000 inwoners

2. het aamtal spreekuurpunten per 1000 inwoners

3. het verschil tussen beide bovengenoemde variabelen als mat voor de concentratie van huisartsen in een gebied

4. de afstand van de woongemeente van de respondent tot de orièntatie-gemeente met algemeen ziekenhuis

5. het aantal klinisch specialisten per 1000 inwoners

6. het aantal bedden in algemene ziekenhuizen per 1000 inwoners.

\section{Ad 1. Het aantal huisartsen per 1000 inwoners}

Deze variabele is iets ingewikkelder berekend dan hij eruit ziet. Ten eerste is het aantal zelfstandig gevestigde $e ̀ n$ het aantal als assistent werkzame huisartsen bij elkaar opgeteld en is dit getal weer gecorrigeerd voor de mate waarin de huisartsen een gedeeltelijke dan wel een wolledige dagtaak vervullen. ${ }^{31}$

Ten tweede is de variabele niet rechtstreeks per gemeente berekend, maar voor een regionale indeling van 181 gebieden, speciaal voor het analyseren van spreiding van huisartsen afgeleid uit de door het CBS vervaardigde indeling in 129 Economisch Geografische Gebieden.

Deze indeling is precies beschreven in Groenewegen en Van der Zee, 1982. Het voor deze 181 rayons berekende getal is toegedeeld aan de gemeente(n) waaruit het rayon bestaat. We hebben herhaalde malen gestell dat het toedelen van dit getal aan personen uit de gemeente in feite niet verantwoord is. Om nu toch te proberen deze variabele als contextuele variabele te gebruiken, hebben we hem omgezet in twee dummy-variabelen, respectievelijk het bovenste en onderste kwartiel van de waarnemingen vormend. De kans op het vinden van een verband is op deze wijze gemaximaliseerd.

\section{Ad 2 en 3. Spreekuurpunten en concentratie van huisartsen}

Het aantal huisartsen-dagdelen is te splitsen in het aantal verschillende praktijkadressen en het gemiddeld aantal dokters (dagdelen) per spreekuurpunt. Dit zijn verre van ideale maten voor de spreiding, want we houden geen rekening met de feitelijke concentratie van praktijkadressen. Twee artsen die vlakbij elkaar spreekuur houden worden als twee aparte punten geteld. Zolang niet ieder adres en unieke combinatie van coördinaten heeft, zijn er, als men niet met de situatie ter plaatse bekend is, weinig andere mogelijkheden. Postcodes hebben een te grillig verloop en vereisen ook plaatselijke kennis. Afgaan op straatnamen en huisnummers veronachtzaamt de ligging van de straten zelf.

Dit is gedaan omdat, zeker voor kleinere gemeenten, de gemeentegrenzen niet behoeven samen te vallen met de praktijkgebieden wan de huisarts.

Als mat voor de concentratie van huisartsen in een gebied hebben we het verschil tussen het aantal huisartsen-dagdelen en het aantal spreekuurpunten (i.e. verschillende praktijkadressen) per 1000 inwoners genomen. 
Is dit verschil kleiner dan nul, dan zijn er meer spreekuurpunten dan dokters; dat wil zeggen, dan zijn de huisartsen sterk gespreid over een gebied (men denke bijvoorbeeld aan de situatie in Den Haag, waar het gewoonte is, dat huisartsen op meer punten spreekuur houden). Naarmate het verschil sterker positief is, zijn er meer huisartsen dan praktijkadressen en zijn de huisartsen sterker geconcentreerd. Men denke hier aan gebieden waar veel groepspraktijken en associaties woorkomen. Naarmate de huisartsen sterker zijn geconcentreerd is de gemiddelde afstand van het adres van de patiënt tot het praktijkpand groter, hetgeen een negatief effect op het aantal contacten zou kunnen hebben. Omdat het ook hier weer om contextuele variabelen gaat hebben we de twee uiteinden van de verdeling in twee dummies omgezet.

Het is de vraag of we een verband zullen vinden: men moet de onder 2 en 3 geformuleerde operationalisering opvatten als een eerste poging om het obligate 'aantal-dokters-per-1000-inwoners' te vervangen door een maat die ook rekening houdt met spreiding en concentratie van de plats waar zorg wordt aangeboden.

\section{Ad 4. Afsiand woongemeente respondent en plaats met algemeen ziekenhuis}

De afstand is met een curvimeter over de weg op kaarten gemeten. Uitgegaan is van de oriëntatiepercentages van 'gemeente van consumptie naar gemeente van productie', die door de Geneeskundige Hoofdinspectie voor de Volksgezondheid worden vervaardigd (de zogenaamde A dorp lijst 1977). ${ }^{32}$

\section{Ad 5 en 6. Bedden en specialisten}

Voor het toekennen wan een aantal ziekenhuisbedden aan een gemeente zonder ziekenhuis is dezelfde procedure toegepast als in deel 1 van de studie 'Tussen le en 2e echelon' (Posthuma \& Van der Zee, 1977).

Deze berekeningswijze komt er op neer, dat eerst aan de hand van de mate waarin de verschillende gemeenten op gemeenten-met-een-ziekenhuis zijn georiënteerd per ziekenhuis-gemeente een rayon wordt geconstrueerd en dat het aantal bedden per 1000 inwoners van dat rayon vervolgens weer aan de gemeenten van dat rayon wordt toegedeeld naar rato van hun oriëntatie op de centrum-gemeente van het rayon. $^{3,3}$

Voor de specialisten, gegevens afkomstig van de specialistenenquête 1978 van het Nationaal Ziekenhuis Instituut, hebben we ongeveer hetzelfde gedaan, beseffend dat dit in feite niet geoorloofd is. ${ }^{34}$ Men gaat dan namelijk van de onderstelling uit dat de rayons van algemene ziekenhuizen en de rayons van de werschillende specialismen dezelfde zijn. Dat gaat zeker niet op voor de verschillende, minder algemeen verspreide, deelspecialismen.

Zou men dit echter per specialisme(groep)rayons willen berekenen, dan moet men beschikken over opnameherkomstgegevens per opnemend specialisme. Dit $70 u$ alleen mogelijk zijn als men alle 1 à $1 \%$ miljoen ziekenhuisopnamen op deze wijze zou sorteren. Even daargelaten dat we niet over zo'n bestand beschikken, kan men 
zich voorstellen welk een immens karwei dit zelfs met geavanceerde apparatuur zou zijn.

Het aantal klinisch specialisten per $] .000$ inwoners is dus op dezelfde wijze berekend als het aantal bedden in algemene en academische ziekenhuizen.

Tot zover de verantwoording van de extra gegevens, die als contextuele variabelen zijn toegedeeld aan de respondenten van het LSO 1977

\subsection{Verwachtingen}

In hoofdstuk 9 staan de voornaamste verwachtingen geformuleerd.

Sommige zijn betrek kelijk eenvoudig van aard; we verwaclyten bijvoorbeeld voor vrouwen in de vruchtbare leeftijd een grotere kans op een contact met de huisarts dan volgens het klachtenmodel voorspeld kan worden. Andere verwachtingen, zoals de verwachting dat naarmate de praktijk van een huisarts groter is, emotioneel labiele patiënten minder vaak door hem terugbesteld zullen worden en dat des te sterker naarmate de mogelijkheden tot verwijzen groter zijn, vergen een ingewikkeller toetsing.

Wij zullen ze hieronder kort resumeren:

1. Wat betreft de gepredetermineerde variabelen uit het model (de 11 variabelen die gebruikt zijn bij het verklaren van de variantie van de variabelen 'chronisch ziek" en "emotionele labiliteit') verwachten wij een te verwaarlozen eigen invloed op de contacten met de huisarts. De meeste enkelvoudige samenhangen zullen in de klachtenscore worden 'wegverklaard'.

2. De variabelen 'chronisch ziek' en 'emotionele iabiliteit'

Voor beide verwachten we cen sterke relatie met de contacten met de huisarts; zij het, dat voor ziekenfondspatiënten geldt dat contacten van beide groepen negatief beïnloed worden door de omvang van de huisartspraktijk en des te sterker naarmate de mogelijkheden tot verwijzen groter zijn.

3. Andere vraagvariabelen

Al gememoreerd is de verwachte grotere kans op cen contact met de huisarts voor vrouwen in de vruchtbare leeftijd. Daarnatast verwachten we meer contacten voor ziekenfondspatiënten en een grotere kans voor een contact-zonder-klachtenscore voor mensen die opgeven acuut ziek te zijn geweest (1-7 dagen). Geeft men op 7-14 dagen ziek te zijn geweest, dan verwachten we niet alleen een positief verband met de kans op een contact maar ook met het áántal contacten.

\section{Aanbodfactoren}

Praktijkgrootte is al eens ter sprake geweest. De kans dat we met dit materiaal interpreteerbare resultaten vinden is minimaal. Immers, het gemiddelde aantal huisartsen per zoveel inwoners in een gebied zegt heel weinig over de omvang van de praktijk van de huisarts van de respondent. Dat geldt niet voor de variabelen die het aanbod aan voorzieningen in het tweede echelon van de gezondheidszorg 
indiceren. Voor deze factoren mag men aanmemen dat ze de ondervraagde personen op een vergelijkbare wijze beinvloeden. Ook hier gelden naturlijk beperkingen, maar ze zijn van minder overwegend belang dan bij de operationalisering van de omvang van de huisartspraktijk met het gemiddeld aantal huisartsen per 1000 inwoners, (al proberen we door het indelen in dummyvariabelen voor de uiteinden van de verdeling toch nog een effect te vinden).

Datzelfde geldt voor de invloed van de concentratie van huisartspraktijken. Hier verwachten we meer contacten tussen huisarts en patiënt als er meer spreekuurpunten dan huisartsen zijn en minder contacten als er meer huisartsen dan spreekuurpunten in een gebied worden aangetroffen.

Van de woorzieningen in de tweede lijn van de gezondheidszorg verwachten we een indirect effect. We verwachten dat de relatie tussen vraag en aanbodfactoren in de huisartspraktijk anders zal zijn in gemeenten waar een ziekenhuis is gevestigd dan in gemeenten die verder van een ziekenhuis vandaan liggen. De verwachte effecten van de afstand tot een gemeente met algemeen of academisch ziekenhuis zal nog worden versterkt door de verdeling van het aantal specialisten per 1000 inwoners. Wij hebben overigens geen aanleiding gezien een ander effect dan een lineaire combinatie van deze variabelen te verwachten; we onderstellen niet bij voorbaat interactie-effecten.

\subsection{Analyse 1 - Wel of niet naar de huisarts}

Wij beginnen met de meest algemene analyse: Bij het verklaren van de kans dat iemand opgeeft de drie maanden voorafgaande aan het wraaggesprek een bezoek aan de huisarts te hebben gebracht of door de huisarts te zijn bezocht.

In de analyse nemen we op:

- alle gepredetermineerde variabelen uit de vorige fase van het model

- de variabelen: VOEG, ABVN en chronisch ziek (CHRON)

- de genoemde aanbodvariabelen.

De resultaten worden in twee versies gepresenteerd: eenmaal met en eenmaal zonder de VOEG-score als verklarende variabele.

Voor de overzichtelijkheid zijn de variabelen afgekort: de beschrijving volgt in tabel 11 . I (zie pagina 141); de analyse-resultaten in tabel 11.2 (zie hiervoor pagina $142-143)$.

Als we het resultaat van dit schot hagel bezien, dan vinden we weinig verrassingen. De analyses met of zonder VOEG verschillen niet sterk. Zonder VOEG is de invloed van de score op de $\mathrm{ABV}-\mathrm{N}$ en de variabele 'chronisch ziek' veel sterker en heeft 'geslacht' een directe invloed op de kans op een bezoek atan de huisarts.

Nu hadden we vooral ondersteld, dat de meeste variabelen uit het in deel I behandelde klachtenmodel de kans op een contacr met de huisarts niet direct zouden beïnvloeden. Ook hadden we (om geheel andere redenen overigens) geen directe 
Tabel 1 1.1.: Beschrijuing variabelen voor de analyse wan doktersbezoek in thet Leef Simutie Onderzoek 1977. Notatic, gemiddelden en standaarddeviaties $(n=4157)$.

Notatie Gemid- Stand.
delde dev.

a. Afhankelijke variabelen. Contact met de huisarts ja-nee ( $1=$ nee, $2=j a)$

HA

1.451

.498

Aantal contacten met de huisarts (worteliransformatie FRHA)

VFRHA 1.335

b. Afhankelijke variabelen wit het klachtemmodel

Score op de VOEG (worteltransformatie VOEG) VVEG 2.00

Score op de $A B V N$

$\mathrm{ABVN} \quad 3.55$

1.73

Chronisch ziek $(1=\mathrm{ja}, 0=$ nee)

CHRON $\quad .33$

c. Onafhankelijke variabelen uit het klachtemmodel

Leeftijd in jaren

Geslacht $(1=\operatorname{man}, 2=$ vrouw $)$

Soc. econ. status $(1=$ hoog, $2=$ midden, $3=$ latg)

Dummy - Status laag - leeftijd $35-44$ jr

Dummy - arbeidsongeschikt

Dummy - werkloos

Dummy - weduwe of weduwnaar

Dummy -- gescheiden

aantal inwoners wan woongemeente (logarithmische transformatie
LFT

42,32

17.982

$\mathrm{SEXE}$

1.50 500

SES

DI

WAO

WW

WED

$\mathrm{GESCH}$

LOURB

10.5

Mate van integratie $(1=z$ wak geintegreerd,

$9=$ sterk geintegreend)

$I^{\prime} \mathbb{L}^{*}$

4.83

Mate van religieuze binding ( $1=$ kerks en kerke-

lijk, $3=$ onkerkelijk, $2=$ rest $)$
REL

d. Vraagvariabelen buiten het klachtenmodel

Durnmy: Acuut ziek (1) - 1.7 dagen thuts gebleven ACUllw

Dummy: Acuut ziek (2) - 8-14 dagen thusgebleven ACU2w

Dummy: Vrouw in wruchtbare leeftijd

Dummy: Particulicre zicktekostenverzekering

PART 
Notative Gemid Stand.

delde dev.

e. Aanbodvariabelen

A.antal huisartsen + assistenten per 1000

inwonets in de regio

HAINW $\quad .361 \quad .043$

Durmy: > gemiddelde $+1 *$ St. dev. HAINW DIKDOK ${ }^{156} \quad .363$

Dummy: < gemiddelde - 1 * St. dev. HAINW DUNDOK $.173 \quad .379$

Verschil adutal huisartsen per 1000 inwoners en

aantal spreekuurpunten per 1000 inwoners

DFHASPR $\quad .047 \quad .044$

Dummy: meer spreekuurpunten dan huisartsen per

1000 inwoners (DFHASPR $<0$ )

SPRE- $\quad .065$

MEER

Dummy: $>$ gemiddelde +1 * St. dev. DFHASPR

DOK-

MEER

Aantal specialisten per 1.000 inwoners

SPINW $\quad .444$

.154

Afstand tussien woongemeenten en gemeente met

algemeen ziekenhuis (in $\mathrm{km}$ )

AFST $\quad 5.40$

7.65

Tabel 112.: Resultaten regressie-analyse kans op en bezoek aan of van de huisarts met en zonder VOEG-score als onafhankelijke variabele Leef Situatie Onderzoek $1977 \mathrm{n}=4157$ (voor betekenis van de afkortingen zie pagina 141-142).

Bcoeff T-waarde Bcoëff T-waarde

\begin{tabular}{|c|c|c|c|c|c|}
\hline $\begin{array}{l}\text { afh. var. } \\
\text { klachteri } \\
\text { model }\end{array}$ & $\begin{array}{l}\text { VVOEG } \\
\text { ABVN } \\
\text { CHRON }\end{array}$ & $\begin{array}{l}.126 \\
.0113 \\
.122\end{array}$ & $\begin{array}{r}11.57 \\
2.33 \\
6.98\end{array}$ & $\begin{array}{l}.0364 \\
.188\end{array}$ & $\begin{array}{r}8.27 \\
11.26\end{array}$ \\
\hline \multirow{11}{*}{$\begin{array}{l}\text { onafhanke- } \\
\text { lijke wa- } \\
\text { riabelen } \\
\text { uit het } \\
\text { klachten- } \\
\text { model }\end{array}$} & $\mathrm{LFT}^{\circ}$ & .0023 & 4.15 & .0029 & 5.20 \\
\hline & SEXE & .0165 & .72 & .0450 & 2.03 \\
\hline & SES & 0881 & .78 & .0117 & 1.02 \\
\hline & DI & .0157 & .51 & .0267 & .87 \\
\hline & WAO & .0235 & .53 & .0726 & 1.64 \\
\hline & WW & .0440 & .76 & 0461 & .78 \\
\hline & WED & .0414 & 1.29 & .0266 & .82 \\
\hline & GESCH & .0197 & .30 & -.0032 & .05 \\
\hline & LAURB & .0093 & 1..34 & .0121 & 1.73 \\
\hline & $\mathbb{I N T}$ & -00052 & 1.61 & -.0063 & 1.93 \\
\hline & REL & -.0046 & 46 & -.0027 & .25 \\
\hline
\end{tabular}


Bcoeff T-waarde Bcoeff Twwarde

\begin{tabular}{llcccr}
\hline andere & ACU1w & .203 & 9.58 & .223 & 10.39 \\
vraag & ACU2W & .337 & 8.66 & .376 & 9.55 \\
varia- & VR1545 & .0656 & 2.46 & .0599 & 2.21 \\
belen & PART & .0013 & .07 & -.0052 & .29 \\
\hline aanbod & DUNDOK & -.0142 & .70 & -.0000 & .74 \\
varia- & DIKDOK & -.0006 & .03 & -.0032 & .16 \\
belen & SPREMEER & -.0428 & 1.44 & -.0536 & 1.79 \\
& DOKMEER & .0321 & 1.39 & .0262 & 1.12 \\
& SPINW & -.0383 & .73 & -.0575 & 1.08 \\
& AFST & .0013 & 1.07 & .0015 & 1.27 \\
\hline & CONST & .860 & 10.07 & .905 & 10.37 \\
\hline
\end{tabular}

relaties verwacht met de factoren aan de aanbodzijde.

Van de variabelen die buiten het oorspronkelijk klachtenmodel vallen (acuut ziek; vroww in vruchtbare leeftijd; verzekeringsworm) hebben de twee variabelen die een acute ziekte representeren (de afgelopen 3 maanden respectievelijk 1 week of minder dan wel $1-2$ weken thuis gebleven wegens ziekte) een duidelijke invloed op het doktersbezoek. Ziekte blifft iets dat iemand gewoon kan overkomen. Vrouwen in de vruchtbare leeftijd hebben inderdaad een grotere kans op een contact met de huisarts; de verzekeringsworm doet er niet toe. Dit laatste had Mootz (1980) al aangetroffen in dit materiaal en ook Van Vliet en Van de Ven (1982) kunnen niet om dit resultaat heen. Men kan echter niet zonder meer de conclusie trekken dat de slechtere gezondheidstoestand van personen uit de lagene sociale strata alleen verantwoordelijk is voor dit resultaat. Ook spannings-en malaiseklachten spelen een rol, waarbij thet de vraag is of deze en, zo ja, hoe deze klachten in de gezondheidszorg moeten worden opgevatigen. Zolang het aanbieden van deze klachten beperkt blijt tot de huisarts is dat niet zo'n probleem. De huisarts echter heeft, als een ware tovenaarsleerling de beschikking over machtige middelen, doorwerwijzing nax specialist of fysiotherapeut en het gehele arsenall wan de farmaceutische industrie, zonder andere restricties op het gebruik dan zijn eigen beroepsethek. In deze analyse winden we aan de aanbodzijde weinig. Wij hadden ook niet verwacht veal te vinden. Opvallend (inderdaad 'opvallend', want we hadden precies het ongekeerde verwacht) zijn de tekens van de (niet significant van de restcategorie 
maar wel significant van elkaar verschillende) coëfficiënten voor onze maten voor concentratie van huisartsen. Als er meer spreekuurpunten dan huisartsen zijn, is de kans op een doktersbezoek kleiner dan als er meer dokters dan spreekuurpunten in een gebied zijn.

Dit kan terug tè voeren zijn op bijzondere omstandigheden (de situatie met meer spreekuurpunten dan huisartsen doet zich vooral in Den Haag voor), maar het kan ook zijn dat weliswaar de artsen zeer sterk over het gebied gespreid zijn, maar dat dit gepaard gaat met een relatief slechte bereikbaarheid; de spreekuurpunten zijn immers maar voor een deel van de tijd bezet. Een sterkere concentratie daarentegen gaat vermoedelijk samen met een hoge mate van bereikbaarheid; er is altijd wel iemand op het praktijkadres aanwezig. In dit licht bezien is het gewonden verband nog wel te interpreteren. Het zou zeker de moeite waard zijn de waarschijnlijk tegengestelde effecten van concentratie, grotere gemiddelde afstand, maar ook meer continue bereikbaarheid nader te onderzoeken.

We vinden geen effect van de huisartsendichtheid in een gebied, ook al hebben we onze analyse toegespitst op inwloed van de twee extreme groepen. Het aggregatieniveau is waarschijnlijk te hoog voor het vaststellen van een relatie. Iemands contact met huisarts moet in verband gebracht worden met de vorm of de omvang van de praktijk van zijn eigen huisarts en niet met een geaggregeerd gemiddelde voor het gebied waar de respondent woonachtig is.

De omvang van en afstand tot de tweedelijnsgezondheidszorg heeft geen invloed op de kans op een bezoek aan de huisarts; de coëfficiënten verschillen niet significant van nul.

\subsection{Analyse 2 - Het aantal contacten met huisarts gegeven het feit dat men éénmaal is geweest}

Niet alleen de kans op een bezoek aan of van de huisarts interesseert ons, maar ook de frequentie van het contact als eenmaal een contact heeft plaatsgevonden. Daarom selecteren we uit het bestand de personen die opgeven tenminste fénmaal bij de huisarts te zijn geweest. Wij kunnen nu een aantal variabelen uit de analyse laten: namelijk de gepredetermineerde variabelen uit het klachtenmodel die immers niet met de kans op een contact samenhangen. Leeftijd en geslacht laten we staan, omdat de door deze variabelen verklaarde variantie niet geheel gedekt wordt door de variabelen uit het klachtenmodel. De aanbodvariabelen handhaven we, evenzo de buiten het klachtenmodel vallende vraagfactoren.

Omdat het hier een selectie uit het bestand betreft geven we de gemiddeiden en standaarddeviaties van de in de analyse opgenomen wariabelen opnieuw weer (tabel 11.3) en vervolgens de resultaten van de regressie-analyse (tabel 11.4) 
Tabel 11.3.: Gemiddelden en standaarddeviaties van de variabelen gebruikt in de analyse van het aantal contacten met de huisarts van degenen die tenminste eén contact rapporteren. Leef Situatie Onderzoek 1977 $\mathrm{n}=1868$.

Variabele

(worteltrans.)

VFRHA $\quad 1.745$

.522

Voegscore (worteltransformatie VOEG)

VVOEG $\quad 2.30$

.858

ABV-N

ABVN

3.92

1.899

Chromisch ziek $(1=\mathrm{ja}, 0=$ nee $)$

CHRON

.454

.498

Leeftijd in jaren

LFT

44.63

18.46

Geslacht $(1=\operatorname{man}, 2=$ vrouw $)$

SEXE

1.55

.498

Dummy: Vrouw in vruchtbare leeftijd

VR 1545

.292

.455

Dummy: Acuut ziek 1 (1-7 dagen thuis)

ACU1w

.186

.389

Dummy: Acuut ziek 2 (8-14 dagen thuis)

$\mathrm{ACU} 2$ w

.065

.246

Dummy: Particuliere ziektekostenverzekering

PART

.238

.426

Dummy: Aantal huisartsen + assistenten per 1000 inwoners $>$ gemiddelde + 1 * standaarddeviatie

DIKDOK

.177

Dummy: Aantal huisartsen + assistenten per 1000 unwoners < gemiddelde 1* standaarddeviatie

DUNDOK $\quad .149$ .356

Dummy: Meer spreekuurpunten dan huisartsen per 1000 inwoners. (DFHASPR $<0$ )

SPREMEER $\quad .058$

Dummy: Meer huisartsen dan spreekuurpunten $>$ gemiddelde +1 * standaarddeviatie

DOKMEER 118 
Afstand tot plats met algemen ziekenhuis

(in $\mathrm{kms}$ )

AFST

5.29

7.62

Aantal specialisten per 1060 inwoners

SPINW

Tabel 11.4: Resultaten regressie-analyse van het amtal contacten met de huisarts voor degenen die tenminste één contact rapporteren LSO 1977 $\mathrm{n}=1868$ (voor betekenis der afkortingen zie pagina 145).

\begin{tabular}{|c|c|c|c|c|}
\hline Variabele & Bcoëff. & T-waarde & Bcoëff. & T-waarde \\
\hline VVOEG & .101 & 6.10 & - & -- \\
\hline$A B V N$ & .0154 & 2.19 & .0352 & 5.61 \\
\hline CHRON & .107 & 4.15 & .153 & 6.11 \\
\hline $\mathrm{LFT}$ & .0021 & 2.35 & .0025 & 2.80 \\
\hline SEXE & -.0091 & .28 & .0073 & .22 \\
\hline VR 1545 & .0291 & .70 & .0283 & .67 \\
\hline ACU1w & -.0079 & .26 & .0006 & .02 \\
\hline $\mathrm{ACU} 2 \mathrm{~W}$ & .203 & 4.25 & .222 & 4.62 \\
\hline PART & -.0229 & .83 & -.0361 & 1.31 \\
\hline AFST & .0070 & 4.53 & .0070 & 4.49 \\
\hline SPINW & -.0319 & .39 & -.0472 & .57 \\
\hline DUNDOK & -.0345 & 1.03 & -.0393 & 1.17 \\
\hline DIKDOK & -.0006 & .17 & -.0098 & .29 \\
\hline SPREMEER & -.0271 & .54 & -.0465 & .92 \\
\hline DOKMEER & -0378 & 1.03 & -.0503 & 1.37 \\
\hline CONST & 1.299 & 19.11 & 1.402 & 21.07 \\
\hline Schattingsparam & .09 & \multicolumn{3}{|c|}{$\tilde{\mathrm{R}}^{2}=.07$} \\
\hline
\end{tabular}

\section{Commentaar}

De proportie verklaarde variantie is laag. De resultaten zijn voor de versie met of zonder $\mathrm{VOEG}$ eensluidend. Vooral de variabelen die de ernst van een aandoening aangeven (chronisch ziek, acuut ziek maar langer dan een week, leeftijd) dragen bij aan het verklaren vari de variantie. Ook een hoge score op de ABVN, een üting van emotionele labiliteit is een goede voorspeller van het aantal contacten met de huisarts. Vrouwen en in het bijzonder vrouwen in de vruchtbare leeftijd komen niet extra wak bij de huisarts. In de vorige analyse hebben we gezien dat ze wel een 
grotere kans hebben op een huisartscontact, maar gegeven dat contact komen ze niet vaker dan mannen, de overige omstandigheden, waaronder hun (hogere) score op de $A B V-N$, in aanmerking nemende.

Aan de aanbodzijde vinden we alleen een verband tussen de afstand tot een algemeen ziekenhuis en het aantal contacten; gegeven één contact. Hoe verder men van het ziekenhuis vandaan woont des te vaker heeft men contact met de huisarts àls men eenmaal is geweest. Het is wel zo dat de kans op een contact niet groter is. Deze uitkomst is wel te rijmen met onze verwachtingen dat substitutie tussen terugbestellen en verwijzen afhankelijk is van de mogelijkheden om te verwijzen. Wij hebben immers gesteld dat de afstand tot een ziekenhuis en het aantal specialisten in een gebied beschouwd kunnen worden als omstandigheden waaronder de relatie tussen huisarts en patiënt een bepaalde vorm aanneemt. In de volgende paragraaf zullen we hierop nader ingaan.

\subsection{Doktersbezoek onder verschillende condities}

Enkele van de in paragraaf 3 geformuleerde verwachtingen zijn niet met een 'gewone' regressie-analyse te toetsen.

Zo voorspelden wij dat huisartsen, afhankelijk van de grootte van hun praktijk en de mogelijkheid tot verwijzen chronische patiënten en emotioneel labiele patiënten verschillend zouden behandelen.

Met alle slagen om de arm (alleen de mogelijkheid om te verwijzen is enigszins acceptabel gemeten) kunnen we een poging tot toetsing wagen.

Wij willen het verband bestuderen tussen de variabele 'chronisch ziek (CHRON)' en de ABVN en het aantal contacten met de huisarts (VFRHA) onder telkens verschillende combinaties van omstandigheden.

De omstandigheden zijn:

- afstand van de woongemeente van de respondent tot een plaats met een algemeen ziekenhuis; in tweeèn gedeeld: wel of geen ziekenhuis in de gemeente

- het aantal specialisten per 1000 inwoners (rond de middelste waarde (.397) in tweeen gedee]d)

- het aantal huisartsen per 1000 inwoners (ook weer rond de mediaan (.358) gedichotomiseerd).

Dit geeft 8 verschillende combinaties; binnen deze combinaties kijken we naar de samenhang (de regressiecoëfficiënt B) tussen CHRON, ABVN en VFRHA met inachtneming van de onderlinge samenhang tussen ' $C H R O N$ ' en ' $A B V N$ '.

Men kan niet zomaar de regressiecoëfficiënten vergelijken. De cellen zijn niet gelijk gevuld; er is namelijk een samenhang tussen huisartsendichtheid en specialistendichtheid en tussen specialistendichtheid en de aanwezigheid van een algemeen ziekenhuis. De omwang van de betreffende groep heeft invloed op de betrouwbaarheid van de coëfficiënt. Wij gaan daarom uit van de $95 \%$ betrouwbaarheidsinterval- 
len. Deze zijn wel te vergelijken, omdat hier met de groepsgrootte en de variantie rekening gehouden is. We bezien dus (in tabel 11.5) hoe sterk het verband is tussen het aantal contacten met de huisarts en iemands score op de $A B V-N$ en het gegeven dat iemand één of meer chronische aandoeningen heeft.

Wij geven de resultaten weer voor personen die bij een ziekenfonds verzekerd zijn en personen waarbij dat niet het geval is (op een zeer kleine groep "niet-werzekerden" na, zijn dit personen met een particuliere ziektekostenverzekering). In tabel 11.5 staat dus nogal wat informatie op de vierkante centimeter. Wij hebben daarom de betrouwbarheidsinterwallen nog eens grafisch weergegeven, zodat de lezer (en de schrijver) het trekken van conclusies enigszins vergemakkelijkt wordt.

Tabel 11.5.: 95\% betrou wbaarheidsinterwallen van de regressiecoëfficiënten voor de variabelen 'ABVN' en 'CHRON" op het aantal contacten met de huisarts onder verschillende condities aan de aanbodzijde van de gezondheidszorg voor wel of niet ziekenfondsverzekerden LSO = $1977 \mathrm{~m}=4157$.

\begin{tabular}{|c|c|c|c|c|c|}
\hline & & \multicolumn{2}{|c|}{ weing buisantsen } & \multicolumn{2}{|c|}{ weel loulisartusen } \\
\hline & & zarelyerlonds & particulier & rickenfonds & particulitier \\
\hline \multirow{6}{*}{$\begin{array}{l}\text { alg } \\
\text { zileken- } \\
\text { huis } \\
\text { in } \\
\text { ge- } \\
\text { minechte }\end{array}$} & weel & $n=227$ & $n=93$ & $1=673$ & $n=246$ \\
\hline & specta- & ABVN- 011.06 n.s. & ABVNM,03r.05 m.s. & ABVN.03/.06 & ABVN.01/08 \\
\hline & lis.tien & CHRON $14 / .39$ & CHRON $07 /, 38$ & CHRON.20,36 & CHRON.10/.35 \\
\hline & weinig & $\pi=501$ & $n=186$ & $n=215$ & $n=69$ \\
\hline & speciat- & ABVN.011.05 & ABVN-03\%05 & ABVN $03 / . H 0$ & ABVN- $04 / .06$ h.s. \\
\hline & listen & CHRON 19,34 & CHRON $08 / 39$ & CHRON 10\% 38 & CHRON- $0.4 / 32$ n.s. \\
\hline \multirow{6}{*}{$\begin{array}{l}\text { alg. } \\
\text { zlieken- } \\
\text { huis } \\
\text { buiten } \\
\text { ge } \\
\text { meente }\end{array}$} & vert & $n=301$ & $n=151$ & $n=267$ & $n_{1}=128$ \\
\hline & spectia. & $A B V N .03 / 11$ & ABVN.05\%.14 & $\mathrm{ABVN}, 02 / 08$ & ABVN-.061.08 II.5. \\
\hline & lisfen & CHRON. 3 .41 & CHRON-03/35 $\mathrm{TH} .5$ & CHRON $15 / .38$ & CHRON $3 / 181$ \\
\hline & weinig & $n=359$ & $n=141$ & $\pi=455$ & $n=143$ \\
\hline & specia. & ADVN.04:109 & ABWN- 03/05 & ABVN.06/. & ABVN.02/12 \\
\hline & lisiten & CHRON.15/.36 & CHRON,09/.38 & CHRON 15,38 & CHRON- $04 / .31$ n.s. \\
\hline
\end{tabular}

In figuur 1.1 .1 en 11.2 zijn de intervallen voor ziekenfondswerzekerden weergegeven in een continue lijn; voor "particulieren" is een onderbroken lijn getekend. Als de coëfficiënt niet significant van nul verschilt is dat met n.s. weergegeven (dit geldt ook voor de tabel).

\section{Emotionde labiliteit}

Wij kunnen figur 11.1 op verschillende manieren bekijken. De twee meest extreme omstandigheden verschillen (althans voor de $\mathrm{ZF}$-verzekerden) het sterkst. De enige niet-significante coëfficiënt treft men aan als er in de gemeente een ziekenhuis is gevestigd terwijl er naar verhouding veel specialisten en weinig huis- 
artsen zijn. De sterkste coëfficiënt vindt men als er veel huisartsen en weinig specialisten zijn en er geen ziekenhuis is. In het algemeen (we spreken nu alleen over ziekenfondspatiënten) zijn de coëfficiënten sterker als er geen zickenhuis in de woongemeente van de respondent aanwezig is. Een uitzondering vormt de situatie waarin men relatief weinig specialisten en veel huisartsen telt (groep 4). Bij drie van de vier combinaties van deze twee omstandigheden (groep 1 ws $2 ; 3$ vs $4 ; 7$ ws 8 ) vindt men sterkere coëfficiënten als er meer huisartsen zijn. Dat wil zeggen: hangt een hogere score op een lijst met niet-lichamelijke klachten samen met meer doktersbezoek.

Dit geldt in ieder geval voor de situatie waarin er sprake is van weinig specialisten (3

Figuur 11.1.: Grafische weergave van de betrouwbaartheidsintervallen wan de regressiecoëfficiënt van de score op de $\mathrm{ABVN}$ op het aantal contacten met de huisarts voor well of niet ziekenfondswerzekerden onder verschillende condities aan de aanbodzijde van de gezondheidszorg. LSO 1977. $\mathrm{n}=4157$.

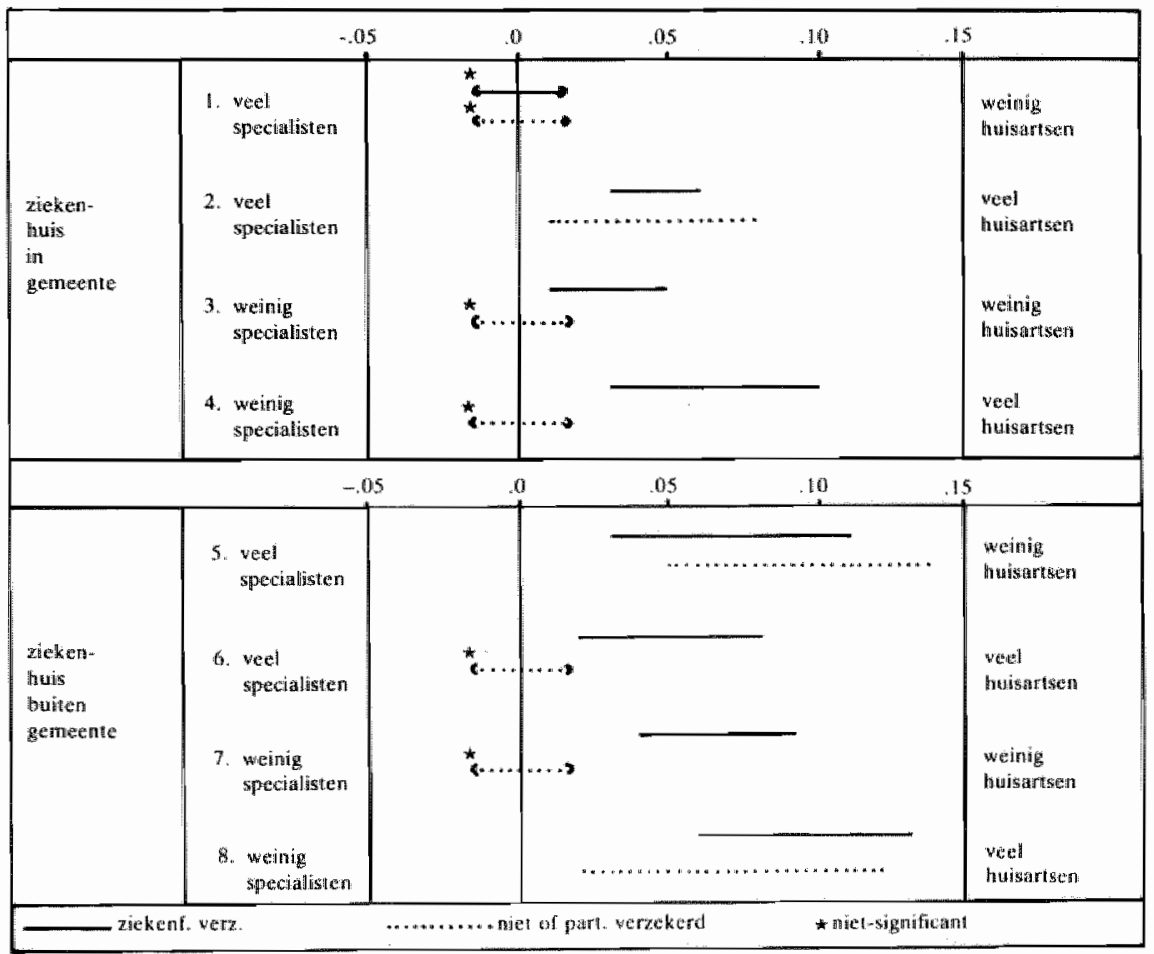


*s 4 en 7 vs 8). Zijn er weel specialisten ( 1 vs 2 en 5 ws 6 ) dan zien we een minder duideijk resultaat; in het eerste geval ( $1 \mathrm{ws} 2$ ) een niet significante versus een significante coefficient. In het tweede geval vinden we precies het omgekeerde en hebben personen meer contacten met de huisarts naarmate hun ABVN-score hoger is als er relatief weinig huisartsen zijn, dan als er sprake is van een grotere huisartsendichtheid.

Toch kan men alles bij elkaar wel spreken van een interpreteerbaar resultaat. Voor ziekenfondswerzekerden geldt dat ze bij emotionele labiliteit meer contacten met huisartsen hebben naarmate er meer huisartsen in hun omgeving zitten en naarmate de mogelijkheden om te verwijzen geringer zijn. Een uitzondering vormt de situatie waarin geen ziekenhuis in de gemeenten gevestigd is, maar deze gemeente wel binnen een gebied valt met naar verhouding veel specialisten.

Voor particulier verzekerden zijn de verbanden minder duidelijk. In slechts 3 van de 8 omstandigheden is er sprake van een significante coëfficiënt, namelijk in groep 2 -wel ziekenhuis, veel specialisten en veel huisartsen; in groep 5 geen ziekenhuis in gemeente, veel speciallisten en weinig huisartsen en in groep 8: geen ziekenhuis, weinig specialisten en veel huisartsen. In groep 5 zien we hetzelfde, niet interpreteerbare resultaat als voor de ziekenfondswerzekerden. Met een beetje goede wil kan men stellen, dat de aanwezigheid van een ziekenhuis wel enige invloed op de coëfficiënt heeft.

\section{Chronisch ziek}

Voor de variabele 'chronisch ziek' kunnen we op dezelfde wijze de coëfficiënten grafisch weergeven (grafiek 11.2 op pagina 163).

In tegenstelling tot de vorige grafiek valt hier wat betreft de ziekenfondsverzekerden nauwelijks variatie waar te nemen. Alle coëfficiënten zijn ongeveer van gelijke sterkte. Mensen die opgeven dat ze éên of meer chromische aandoeningen bezitten, hebben onder uiteenlopende omstandigheden (wonend in een plaats met een ziekenhuis of in een plaats zonder ziekenhuis; wonend in een gebied met relatief veel of weinig specialisten dan wel huisartsen) ongeveer eenzelfde aantal contacten met de huisarts. Van substitutie vinden we hier niets. Voor particulier verzekerden variëren de resultaten wat sterker; $z$ ij het dat de resuitaten moeilijk te interpreteren zijn. Waar een ziekenhuis in de gemeente is gevestigd vindt men ongeveer hetzelfde patroon als bij de ZF-verzekerden behalve in de situatie met relatief weinig specialisten en veel huisartsen; daar vindt men geen verband.

Is er geen ziekenhuis in de gemeente dan zijn de resultaten grilliger.

Tweemaal wijkt de coëfficiënt niet significant van nưl af (in de contrasterende gevallen van veel huisartsen en weinig specialisten en veel specialisten en weinig huisartsen) en énmaal vinden we een verband dat de grafiek uitschiet, namelijk in het geval van veel specialisten èn veel huisartsen. Daar vindt men ineens een zeer 
Figuur 11.2: $95 \%$ Betrouwbaarheidsintervallen van de regressie-coefficienten voor de variabele 'chronisch ziek' op het aantal contacten met de huisarts voor wel of niet ziekenfondsverzekerden, onder verschillende condities aan de aanbodzijde wan de gezondheidszorg. LSO 1977.

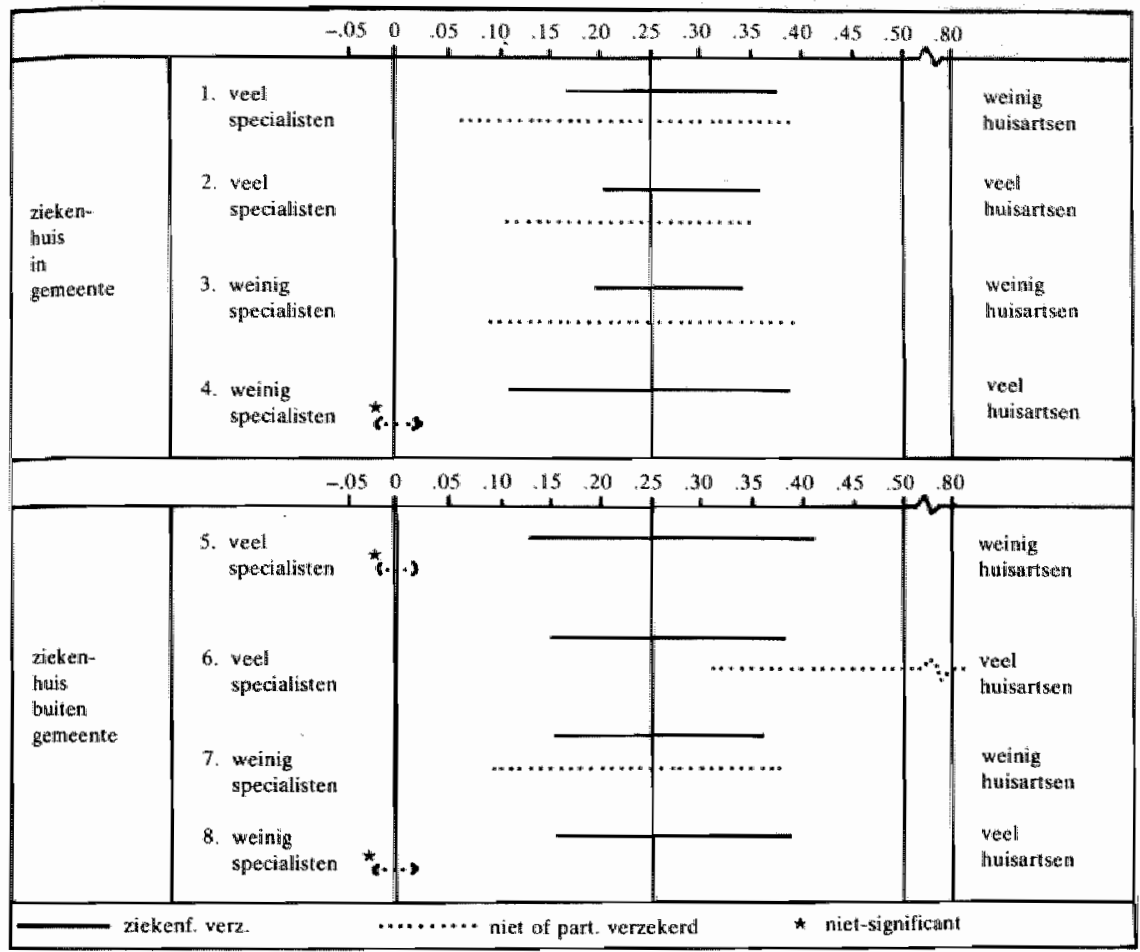

sterke samenhang tussen de frequentie van contacten met de huisarts en de variabele 'chronisch ziek', zonder dat achteraf te ver'klaren is waarom dit het geval zou zijn.

\subsection{Samenvatting en conclusie}

Men zou hoofdstuk 11 kunnen omschrijven als het hoofdstuk van de gestrande goede bedoelingen. We konden immers bij voorbaat aangeven, waarom een analyse wan 'doktersbezoek' uit het Leef Situatie Onderzoek 1977 weinig zichtbare resultaten zou opleveren. Onze aanpak: - eerst verklaren waarom mensen klagen, en in 
een tweede fase waarom ze naar de dokter gaan - liep wast op de geringe proportie verklaarde wariantie van de klachtenscores. Daarnaast bevatte het LSO geen variabelen uit de aanbodzijde van de gezondheidszorg.

We hadden twee redenen on toch een hoofdstuk toe te voegen aan ons verhaal:

1. wilden we de invloed onderzoeken van factoren aan de vraagzijde die buiten ons klachtenmodel vallen

2. is het een goede oefening om alvast enkele voorspellingen te formuleren voor de werking van aambodfactoren.

Op grond van deze overwegingen hebben we het LSO-material op verschillende manieren geanalyseerd.

De eerste analyse werd uitgevoerd ter verklaring van de kans op een bezoek aan de huisarts in de drie maanden voorafgaand aan het vraaggesprek. In deze analyse werden de volgende groepen variabelen opgenomen:

a. Alle in deel I (het klachtenmodel) opgenomen onafhankelijke (gepredetermineerde) variabelen. Dit waren er 11: demografische variabelen, variabelen die langdurige probleemsituaties indiceren en variabelen die te maken hebben met iemands integratie in de samenleving.

b. De drie afhankelijke variabelen in het klachtenmodel (chronische ziekte, emotionele labiliteit en lichamelijke klachten).

c. Enkele vraagfactoren die buiten het klachtenmodel vallen (acute ziekte, vrouw in vruchtbare leeftijd, verzekering tegen ziektekosten).

d. De door ons aan het bestand toegevoegde aanbodkenmerken (het gemiddeld aantal huisartsen per 1000 inwoners, een maat voor de concentratie van spreekuurpunten, het aantal specialisten en ziekenhuisbedden per $\mathbb{1 0 0 0}$ inwoners, de afstand tot een algemeen ziekenhuis).

We zagen in deze analyse, dat de oorspronkelijke onafhankelijke variabelen (behalve een zeer krachtige factor als 'leeftijd') geen invloed meer hebben op 'doktersbezoek' als de lijsten met lichamelijke en psychische klachten en de maat voor chronische ziekte in het model zijn opgenomen. Dit brengt ons tot de slotsom, dat én van de redenen waarom dit soort onderzoek altijd oplevert dat mensen naar de dokter gaan als ze klachten over hun gezondheid hebben, is, dat het effect wan factoren die op hun beurt het klagen weer beinvloeden, bij gelijktijdige invoer. verdwijnt onder het geweld van het effect van de klachtenscores zelf.

Wat betreft de niet in het klachtenmodel opgenomen vraagfactoren, vinden we dat vrouwen uit de vruchtbare leeftijd een grotere kans op een doktersbezoek hebben en dat ook acute ziekteperiodes, onafhankelijk van de invloed van de klachtenscores, samenhangen met een grotere kans op een contact met de huisarts.

Wat betreft de aanbodfactoren vonden we, zoals verwacht, geen relatic met de kans op een contact. Een uitzondering vormt de mat die de concentratie van spreekuurpunten weergeeft. Als er meer spreekuurpunten dan huisartsen zijn, dat will zeggen als de huisartsen hun tijd over meer adressen verdelen, windt men een geringere kans op een contact dan als de huisartsen in associaties of groepspraktij- 
ken zijn geconcentreerd. Wij hadden het omgekeerde verwacht op grond van de grotere gemiddelde afstand tot het praktijkpand in het laatste geval. Het ziet er naar uit dat onze verwachtingen niet volledig waren geformuleerd, en dat bijwoorbeeld concentratie ook gepaard zou kunnen gaan met een grotere bereikbaarheid ( $\mathrm{er}$ is altijd wel ièmand aanwezig). Afstand en continue bereikbaarheid zouden wel eens tegengestelde effecten kunnen hebben.

$\mathrm{Na}$ het analyseren van de kans op een bezoek aan of van de huisarts hebben we in een tweede analyse voor degenen die opgaven een contact te hebben gehad, geprobeerd het áántal contacten te verklaren.

In grote trekken zijn de resultaten samen te vatten in de zinsnede: hoe ernstiger ziek, hoe meer contacten', zij het dat we meer contacten vonden naarmate mensen verder van een ziekenhuis af wonen. De kans op een contact was niet groter, maar àls men komt, komt men vaker. Dit zou goed te interpreteren zijn in termen van een groter aantal terugbestelcontacter.

'Tenslotte bezagen we de relatie tussen 'chronische ziekte." en 'emotionele labiliteit' en het aantal contacten met de huisarts onder een aantal verschillende omstandigheden: in gemeenten met of zonder ziekenhuis; in gebieden met veel en weinig specialisten en in gebieden met veell en weinig huisartsen.

Hoewel we verwachtten dat in gemeenten met veel specialisten en met een algemeen ziekenhuis chronisch zieke patiënten minder vaak zouden worden terugbesteld, vonden we die relatie niet. Onder alle door ons vergeleken omstandigheden is het verband tussen 'chronisch ziek' en 'doktersbezoek' ongeveer gelijk. Wat betreft de relatie 'emotionele labiliteit' en 'terugbestellen' vinden we meer variatie. De meeste contacten treffen we aan als er veel huisartsen en weinig specialisten zijn; de minste in gevallen dat er weinig huisartsen zijn in gemeenten met een ziekenhuis. Het ziet er naar uit, dat hoewel niet altijd exact in de verwachte richting, de structuur van de gezondheidszorg van invloed is op de medische consumptie van mensen met malaise- en spanningsklachten. 


\section{2 \\ Samenvatting van Deel II}

In deel II hebben we aandacht besteed aan factoren die de vraag naar diensten van de huisarts beïnvloeden, die buiten het door ons gehanteerde klachtenmodel liggen. We verwachtten (en vonden) dat vrouwen in de vruch tbare leeftijd meer contacten met huisarts zouden rapporteren, dan op grond van hun gezondheidstoestand en klachtenscore te voorspellen was.

Wij verwachtten en vonden eveneens, dat acute, kortdurende verstoringen van de gezondheid de kans op en de frequentie van een contact met de huisarts zouden beïnloeden, onafhankelijk van de meer op iemands algemene gevoel van onwelbevinden berustende score op een lijst met lichamelijke of psychische klachten.

We vonden (evenals Mootz en Van Vliet en Van de Ven) geen onafhankelijke invloed van de vorm van iemands verzekering tegen ziektekosten op het aantal contacten met de huisarts. De slechtere gezondheid en de sterkere gevoelens val malaise en onwelbevinden van personen uit de lagere sociale strata van de maatschappij, waartoe het grootste deel van cle ziekenfondsverzekerden behoort, zijn verantwoordelijk voor de geringere medische consumptie van particulier verzekerden - zij het dat we moeten aantekenen dat in het gebruikte onderzoeksmateriaal (het LSO 1977) niet expliciet gevraagd is of de particuliere patienten verzekerd zijn tegen de kosten van de diensten van de huisarts. We houden het voor waarschijnlijk dat een betere operationalisering van de wijze van verzekeren wel een relatie met medische consumptie zal vertonen.

Deze extra variabelen atan de vraagzijcle zijn beschreven in hoofdstuk 11 , een hoofdstuk dkt qua onderzoeksmateriaal het directe gevolg is van deel I - ook hier worden de gegevens uit het Leef Situatie Onderzoek geanalyseerd.

Deel II wordt grotendeels in beslag genomen door een analyse van gegevens uit de Engelse gezondheidszorg, namelijk uit het tweede Nationale Morbiditeits Onderzoek (2nd National Morbidity Survey), uitgevoerd in de jaren $1970 / 71$ in zestig 
Engelse en Welse huisartspraktijken. Dergelijke praktijkstudies zijn voor Nederland niet (meer) beschikbaar; het materiaal van Oliemans' morbiditeitsonderzoek uit 1969 is per praktijk niet meer toegankelijk en sindsdien is een dergelijk onderzoek nooit meer uitgevoerd.

De positie van de huisarts in de Engelse gezondheidszorg is te vergelijken met de plaats die deze in de Nederlandse gezondheidszorg inneemt. De Engelse huisarts is zelfstandig ondernemer, wordt in een soort van abonnementshonorarium betalald (een gedifferentieerder honorarium overigens dan bij ons), werkt ook met patiënten die bij hem zijn ingeschreven en vormt de enige toegang tot de hogere echelons van de gezondheidszorg. Op dat punt houdt echter elke gelijkenis tussen beide systemen op. Waar in Nederland de meeste specialisten hun beroep ondernemings: gewijze uitoefenen, hierin gesterkt door een productiebevorderend verrichtingensysteem, zijn ze in Engeland als regel in dienst van het ziekenhuis en ook het ziekenhuis krijgt geen vergoeding voor de verrichtingen van zijn werknemers,

Aangezien we echter in eerste instantie geïteresseerd waren in de invloed van aanbodfactoren in de huisartspraktijk op het aantal contacten tussen huisarts en patiënt en pas in tweede instantie in een mogelijke substitutierelatie tussen contacten in de huisartspraktijk en contacten met specialist of ziekenhuis, achtten we de betreffende gegevens uit het 2 nd National Morbidity Survey bruikbaar voor ons doel.

We hebben al eens helemaal in het begin van ons verhaal gezegd dat de vrag naar diensten van de huisarts alleen op zinwolle wijze in praktijkstudies kan worden onderzocht, maar dat in deze studies de summiere gegevens die over de patient bekend zijn (op de kaart van de huisarts staan meestal - naast uiteraard de medische gegevens - slechts enkele demografische kenmerken vermeld), zouden moeten worden aangevuld met enquêtegegevens, zoals deze in bevolkingsonderzoek worden verzameld. Dit is niet gebeurd in het 2 nd National Morbidity Survey. Daar is van de patiënt alleen de leeftijd en het geslacht geregistreerd.

Nu zijn dit belangrijke variabelen, zo belangrijk zelfs dat we geprobeerd hebben de invloed van praktijkgrootte, praktijkvorm (solopraktijk versus meermanspraktijk) en praktijklocatie (stad/platteland) vast te stellen op thet verschil tussen het atantal contacten op initiatief van de patient en van de huisarts dat in de praktijk is geregistreend en het aantal dat men zou verwachten op grond wan de verdeling van de praktijk naar leeftijd en geslacht.

Deze verwachte aantallen worden berekend uit de contactrequenties per leeftijds/ geslachtsgroep voor alle praktijken tezamen.

We vinden interessante resultaten. De omvang van de huisartspraktijk is wiet van invloed op het aantal contacten op initiatief van de patiënt, maar tamelijk sterk op het aantal terugbestelcontacten. Naarmate de praktijk groter is, vindt men minder terugbestelcontacten (contacten op initiatief van de huisarts) dan men op grond van de verdeling van de praktijk naar leeftijd en geslacht zou verwachten.

Ook vonden wij een verband tussen de praktijkvorm en het aantal contacten met de 
huisarts - zowel wat betreft de contacten op initiatief van de patiënt als op terugbestelcontacten. Solisten rapporteerden consequent meer contacten dan men zou verwachten op grond van de samenstelling van hun praktijk naar leeftijd en geslacht.

Een nadere inspectie van de verschillen tussen contactfrequenties in solo- en samenwerkingspraktijken bracht aan het licht, dat vooral in de relatief gezonde leeftijd/geslacht-categorieën (mannen van 5-24 jaar, vrouwen van 0-14 jaar) de frequenties het sterkste verschilden. Duo- en groepspraktijken bleken, waarschijnlijk door hun wat strakkere organisatie, de initiatieven van deze groepen vooral af te remmen.

$\mathrm{Na}$ te hebben vastgesteld dat factoren aan de aanbodzijde wel degelijk van belang zijn bij het verklaren van de frequentie van het contact tussen huisarts en patiëntengroep, hebben we nog geprobeerd na te gaan of in de Engelse gezondheidszorg een substitutie aan te treffen is tussen contacten in de huisartspraktijk enerzijds en verwijzingen en ziekenhuisopnamen anderzijds. Om dit zinvol te kunnen analyseren is het bestand aangevuld met een ruwe indicatie van de afstand tussen de plaats waar de huisartspraktijk is gevestigd en het meest nabijgelegen algemene ziekenhuis. Er is ook hier weer uitgegaan van het verschill tussen het aantal aangetroffen en op grond van de verdeling van de praktijk naar leeftijd en geslacht verwachte aantal verwijzingen en ziekenhuisopnamen.

De resultaten van deze analyse waren schokkend voor de onderzoeker, vergroeid met de eigenaardigheden wan de Nederlandse gezondheidszorg, waar een factor als afstand-tot-het-ziekenhuis zelfs terug te vinden is in het bedrag dat particulier verzekerden bij hun ziektekostenverzekeraar declareren.

We vonden in het Engelse materiaal voor de ziekenhuisopnamen dat deze positief met het aantal terugbestelcontacten samenhingen en bovendien troffen we des te meer ziekenhuisopnamen aan naarmate de praktijk verder van het ziekenhuis vandaan was gelegen. Poliklinische verwijzingen liet zich met dit substitutiemodel in het geheel niet verklaren.

Het zij toegegeven dat de variabelen die geacht werden aanbodfactoren in de tweede lijn te meten, vrij primitief waren geoperationaliseerd. (Tot onze verbazing bleken gegevens die wij in onze zwak georganiseerde gezondheidszorg zo aan de publicaties van het Nationaal Ziekenhuis Instituut kunnen ontlenen in het strak gereguleerde Engelse systeem geheell te ontbreken - bijvoorbeeld het aantal bedden per 1000 inwoners voor kleinere eenheden dan de 15 Regional Health Authorities).

Het is dus mogelijk dat een meer verfijnde analyse tot andere resultaten zall leiden. Het is echter ook mogelijk - en wij achten dat zelf het meest waarschijnlijk - dat de strakke regulering van de Engelse tweedelijnsgezondheidszorg er voor heeft gezorgd dat de zuigkracht van ziekenhuis en specialist op de huisartspraktijk in Engeland niet terug te vinden is. Dit zou woor degenen die beleid moeten maken en 
uitvoeren in het Nederlandse systeem een belangwek kende gedachtengang kunnen zijn.

Het lijkt erop dat de tweedelijnsgezondheidszorg in Engeland en Walles efficiënter gedistribueerd is dan de Nederlandse. 


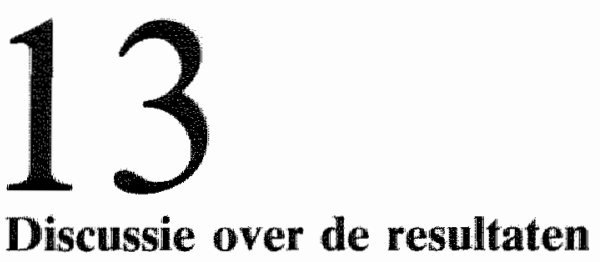

Na zovele pagina's met tabellen en grafieken is de tijd gekomen om de balans op te maken. We zullen proberen drie vragen te beantwoorden.

1. Welke betekenis hebben de resultaten wan dit onderzoek voor het opstellen van een model voor het verklaren en voorspellen van verschijnselen in de gezondheidszorg?

2. Is er aan de resultaten een wetenschappelijke betekenis anders dan onder 1 genoemd toe te kennen?

3. Wat betekenen de resultaten in maatschappelijke zin?

Tenslotte zullen wij, voor zover we dat nog niet hebben gedaan bij het beantwoorden van de vragen, enkele suggesties doen voor nader onderzoek.

\subsection{De betekenis van de resultaten voor de constructie van een model voor de Nederlandse gezondheidszorg}

Als men eén conclusie zou moeten trekken uit dit proefschrift, is het dat het uitermate riskant is on een op enquête-gegevens gebaseerde maat voor gezondheidstoestand op te nemen als indicator voor de 'health status' van de bevolking. Zeker als deze maat bestaat uit de gesommeerde score op een lijst met lichamelijke klachten, dan heeft men te doen met een indicator waarvan de dubbelzinnigheid niet wordt onderkend, paradoxaal genoeg, juist door het succes ervan. Het is namelijk een uitstekende "voorspeller' van allerlei vormen van medische consumptie.

Zo goed zelfs, dat het opnemen van deze maat in een model samen met factoren die 
hun invloed op "doktersbezoek" uitoefenen wia de mat woor lichamelijke klachten, erwoor zorgt dat de invloed van laatstgenoemde factoren onzichtbaar bliff.

Helaas is de door ons gesuggereerde oplossing van dit probleem: een schatting van doktersbezoek in meer stadia, waarbij in een eerder stadium de gesommeerde scores op een lijst met klachten zijn verklaard uit een aantal op hun beurt niet verder verklaarde (gepredetermineerde) variabelen, mislukt bij gebrek aan voldoende verklaarde variantie. Een van de redenen voor deze magere resultaten is gelegen in de beperkingen die wij onszelf hadden opgelegd. Ons doel is en blijft het opstellen van een vraag/axnbod model voor deze sector van de gezondheidszorg. Een dergelijk model moet gebaseerd zijn op algemeen beschikbare globale indicatoren, die. wat de vraagzijde van het model betreft, betrekking hebben op de samenstelling van de bevolking langs demografische, sociaal economische en sociaal culturele lijnen. Persoonlijkheidsfactoren en andere individuele particuliere eigenaardigheden zijn onbruikbaar als men een model wil construeren. Onze wens ons alleen met categorale verschillen in klachtenscores bezig te houden heeft tot dit slechts gedeeltelijk succesvolle resultaat geleid.

Niettemin kunnen we op grond van de resultaten dive we vinden concluderen dat het zinvol is om voor het schatten van de gezondheidstoestand in een populatie niet alleen leeftijd en gesllacht te gebruiken, maar ook sociaal economische status en arbeidsongeschiktheid.

Voor het schatten van het voorkomen van psychische klachten (ook een belangrijke factor in het bezoek aan de huisarts) in een populatie verdient opname van 'burgerlijke staat", "arbeidsongeschiktheid', 'werkloosheid" en "(normatieve) integratie" aanbeveling (naast uiteraard "leeftijd, geslacht en sociaal economische status").

Tot zover onze opmerkingen over de vraagzijde van het model. Ook de aanbodzijde was onclerwerp van studie, zij het dat we hier niet de beschikking hadden over gegevens uit Nederlandse huisartspraktijken maar onze toevlucht moesten nemen tot cijfers uit de Engelse gezondheidszorg.

Voor het opstellen van een model voor de gezondheidszorg zijn de uitkomsten van dit deel van de analyse van belang.

Wij onderzochten de invloed van aanbodfactoren als praktijkgrootte en de praktijkworm en vonden dat praktijkgrootte niet van invloed is op de contacten tussen huisarts en patiënt, die plaats vinden op initiatief van de patient, maar wel op terugbestelcontacten (althans op het verschil tussen het aantal aangetroffen contacten en het aantal dat men op grond van de vercleling van de prakti.jk naar leeftijd en geslacht zou verwachten).

Wat betreft de invloed van 'praktijkvorm", vonden we bij solisten vergeleken met meermanspraktijken een consequent hoger aantal eerste- èn terugbestelcontacten dan men op grond van de verdeling van de praktijk naar leeftijd en geslacht zou verwachten. Bij nadere analyse blijken de verschillen in contacten op initiatief van de patient vooral te vinden te zijn bij relatief jonge (en dus gezonde) mensen: mannen van $5-24$ jaar en vrouwen van 0-14 jaar. Of dit nu te maken heeft met de 
met concentratie van praktijkpunten gepaard gaande grotere gemiddelde afstand tot het praktijkpand, of met een meer geregulearde praktijkorganisatie valt uit dit materiaal niet te zeggen. Te meer niet omdat we in ons Nederlandse materiaal (het enquätematerial van het LSO 1977) een omgekeerde relatie tussen de kans op een bezoek aan of van de huisarts en de spreiding van spreekuurpunten in het gebied vonden. In gebieden met meer spreekuurpunten dan dokters rapporteren minder mensen een contact met de huisarts, dan in gebieden waar de huisartsen naar verhouding sterk zijn geconcentreerd in duogroepspraktijken of gezondheidscentra. Wij hebben dit (ad hoc en achteraf) werklaard wit de wellicht grotere bereikbaarheid van laatstgenoemde prakujiken; er zall altijd wel ièmand aanwezig ziin in het praktijkpand.

Voor het construeren van een model voor het analyseren van dit deel van de gezondheidszorg zijn factoren als concentratie van praktijken, huisartsendichtheid, afstand en praktijkvorm van belang. Voor het bestuderen van de werking ervan zijn gegevens over de 'productie" van huisartspraktijken nodig, die niet als bij-product van het Nederlandse systeem van gezondheidszorg routinematig verzameld worden. Het betrekkelijk goedkope abonnementsysteem waarmee de Nederlandse huisarts wordt gehonoreerd en dat vanwege zijn (administratieve) eenvoud een groot aantal voordelen biedt, heeft én belangrijk nadeel: het verzamelen van informatie uit huisartspraktijk moet met extra kosten en moeite worden gedaan. Deze extra kosten dient men te beschouwen als kosten, die bij het systeem behoren. Bij een verwolganalyse van ons Engelse materiaal, waarin we de relatie tussen 'terugbestellen' en 'verwijzen' willden onderzoeken voor de Engelse gezondheids* zorg, vonden we geen verband tussen het werwijscijfer in de huisartspraktijk en een factor die in Nederland de medische consumptie van patiënten en het handelen van huisartsen rechtstreeks beïnvloedt: namelijk de afstand tot het dichtstbijzijnde algemene ziekenhuis. Er was (bovendien) geen sprake van substitutie tussen terugbestellen en verwijzen. Het zou heel goed kunnen zijn, dat in het Engelse systeem wan gezondheidszorg, waarin met name de tweedelijnszorg veel strakker is gereguleerd en waarin aantallen verrichtingen nauwelijks een rol spelen, hetgeen men woor de jaren 1970/71 (in welke het 2 nd National Morbidity Survey werd uitgevoerd), kan zien aan een verwijscijfer dat vergeleken met Nederland half zo hoog is, de tweedelijnszorg geen 'zuigkracht' op het eerste echelon uitoefent. Dit is een belangrijke constatering. Het zou namelijk geheel niet zo behoren te zijn dat een hoger echelom van de gezondheidszorg 'zuigkracht' uitoefent op een lager echelon, als dit hogere echelon alleen wordt ingeschakeld bij de ernstigere gevalien. Voor de constructie van een model benadrukt deze uitkomst nogmaals het belang van het formuleren en vaststellen van condities en randvoorwaarden waaronder de op grond van de uitkomsten gedane uitspraken geldig ziju. 


\subsection{De betekenis van de resultaten in specifiek social-wetenschappe- lijke zin}

In de vorige paragraaf stelden we vast dat maten, die geacht worden 'gezondheid" te meten in feite ook als indicatoren woor "emotionele labiliteit' kunnen worden beschouwd. Gezien vanuit de wens het functioneren van bepaalde delen van de gezondheidszorg te verklaren, kan men dit in zekere zin (zij het in beperkte mate, omdat ook 'emotionele labiliteit' samenhangt met doktersbezoek) als een handicap beschouwen. Het omgekeerde is echter ook het geval. Een lijst met lichamelijke klachten, bedoeld als indicator woor neurotische labiliteit meet ook "slechte gezondheid'. Dit levert in het bijzonder problemen op als men niet weet of de betrokkene 'gezond' of 'ziek' is. Om de zaak nog ingewikkelder te maken is er ook nog sprake van een samenhang tussen 'slechte gezondheid' èn 'neurotische labiliteit'.

Slechte gezondheid is namelijk één van de zogenaamde 'suboptimale situaties' (de andere die wij onderscheiden zijn 'geen werk meer' en 'geen partner meer') waarin mensen een verhoogde kans hebben zich chronisch ongelukkig te voelen. De dubbelzinnigheid van lichamelijke klachten komt het sterkst tot uiting in de gevallen dat een factor de twee componenten tegengesteld beïnvloedt. Dit is voor 'leeftijd' het geval - hoe ouder men is hoe groter de kans op een chronisch slechte gezondheid, maar hoe minder men in het algemeen geneigd is tot ' $k$ lagen-op-uitnodiging'. Deze tegengestelde relatie is er verantwoordelijk voor dat sommige onderzoekers tot hun verbazing geen of zelfs een tegengesteld verband vonden tussen leeftijd en de score op een lijst met lichamelijke klachten.

Wij hadden het ook niet vreemd gevonden als we voor 'sociale status' eenzelfde tegengestelde relatie hadden aangetroffen. Ook hier vindt men in de literatuur tegenstrijdige resultaten. De meeste onderzoekers vinden dat mensen uit de hogere sociale strata minder klagen dan mensen op de onderste sporten van de maatschappelijke ladder en bovendien is bekend dat iemands gezondheidstoestand beter is naarmate hij beter is opgeleid en beter wordt betaald. Er zijn echter ook theorieën (en onderzoeksresultaten), die juist hogere neuroticisme-scores in de middencategorieèn wan de maatschappij situeren.

Onze eigen bevindingen zijn conform de bevindingen van de eerstgenoende groep auteurs. Iemands status-gebonden score op een lijst met lichamelijke klachten is geheel toe te schrijven aan de met deze status gepaard gaande slechtere gezondheid èn grotere emotionele labiliteit. Hetzelfde vinden we voor de scores van vrouwen; ook hier gaan slechtere gezondheid en grotere emotionele labiliteit aan elkaar geparard.

Over de klachtenscores en gezondheid van wrouwen is in de literatuur nogal wat te doen geweest: vele auteurs heben geprobeerd het parasoxale verschijnsel te verklaren dat vrouwen bij alles wat gezondheid en gezondheidszorg betreft er slechter afkomen dan mannen, behalve bij het ultieme criterium: de dood. Althans wat betreft de huidige en vorige generatie, sinds de dood nog slechts zelden in thet 
kraambed toeslaat. Ook hier vindt men grote verwarring over het aandeel van de "lichamelijke" en "geestelijke" component in de klachtenscores, terwijl de geleerden het ook niet eens zijn over de omstandigheden waaronder vrouwen tot klagen komen. De ene groep auteurs houdt het erop dat het huwelijk een neurotiserende factor is. Voor mannen biedt dit bescherming en is het een protectie tegen riskant gedrag; woor vrou wen zou het hun geestelijke ontplooing te zeer remmen. Anderen betogen dat juist in het geval dat het huwelijk door dood van de partner of scheiding is ontbonden de meeste klachten zullen optreden.

Wij wonden de argumenten woor de laatstgenoemde stelling overtuigender en in eerste instantie werden onze verwachtingen bevestigd.

Later echter vonden wij dat jongeren, wrouwen en gehuwde of altijd ongehuwd geweest zijnde personen meer lichamelijke klachten hebben dan wij met ons model waarin lichamelijke klachten een functie zijn van 'slechte gezondheid' en 'emotionele labiliteit" konden verklaren.

Een nadere categorische analyse van het verband tussen emotionele labiliteit en de omstandigheden waarin jongere, gehuwde of altijd ongehuwd geweest zijnde vrouwen verkeren leverde geen systematische verschillen tussen de onderzochte categorieën op. Wij moesten onze paragraaf over 'de jacht op de groene weduwe' onverrichterzake beëindigen.

Hier dient zich een onderwerp aan voor nadere studie en onderzoek, waarvan de resultaten niet alleen maatschappelijk van belang zijn, maar ook voor de wetenschap die zich bezig houdt met het ontstaan van geestelijke en lichamelijke klachten. Voor het begrijpen en sturen van het functioneren van de gezondheidszorg is meer kennis nodig over de omstandigheden waarin lichamelijke klachten optreden, of over de mate waarin deze klachten überhaupt door omstandigheden te verklaren zijin.

\subsection{De maatschappelijke betekenis van de resultaten}

Voor wie de vorige twee paragrafen heeft gelezen zal het duidelijk zijn dat bij een dusdanig 'foegepast' onderwerp als de vraag naar diensten van de huisarts wetenschappelijke en maatschappelijke betekenis niet te scheiden zijn. Hoeft de algemene matschappelijke betekenis van de resultaten geen nadlere uitleg, de maatschappelijke betekenis in engere zin vergt wellicht enige toelichting. Onder 'maatschappelijke betekenis-in-engere-zin' vallen vragen als 'Wat heeft De Huisarts aan dit proefschrift?" of "Wat kan Het Beleid ermee?".

Het directe nut van de hier gepresenteerde resultaten voor de medicus practicus is beperkt. Tenzij zijn praktijk voornamelijk bestaat ait onkerkelijke, grootstedelijke weduwen.

Indirect echter wordt nog eens benadrukt hoe belangrijk het is dat huisartsen 
systematisch proberen vast te stellen in welke mate er sprake is wan 'functionele' em 'organische' klachten.

Alle geld dat wordt besteed om huisartsen te leren deze beide componenten goed te onderkennen en de hulpvraag van hun cliënt niet direct te interpreteren als vraag om medische of zelfs medisch-specialistische hulp, is goed besteed.

Het grote arsenaal aan middelen dat de huisarts ter beschikking stat en dat hij hanteert of moet hanteren om de totale hoeveelheid tijd-per-patiënt-per-jaar niet boven de 45 minuten te doen uitkomen, maakt dat een onder tijdsdruk verwezen patiênt een fikse, zoals men dat in Nijmegen noemt, somatische fixatie oploopt en de collectieve middelen weer een stukje verder zijn uitgeput.

Als men vraagt wat het 'Beleid' (hoe vaag en misleidend die term ook moge zijn) met de resultaten kan, dan zou men naar aanleiding wan de woorgaande alinea kunnen stellen dat beleidsinitiatieven die de taak van de huisarts bij het opsporen en behandelen van functionele klachten verlichten, voorrang dienen te hebben in de gezondheidszorg.

Uit onze analyse van de Engelse gezondheidszorg kan men zien dat strikte regulering en inperking van de specialistisch medische zorg daartoe een noodzakelijke voorwaarde is. Een 'wachtlijst' voor minder acute operaties moet men maar voor lief nemen.

Naast deze algemene uitspraken kan men ook nog wel op enkele specifieke onderdelen spreken van direct maatschappelijk relevante uitspraken.

Zo constateerden wij bijwoorbeeld op het gebied wan "gezondheidstoestand" dat bij mensen uit de lagere strata van de matschappij de gezondheid al vanaf het $35 \mathrm{e}$ levensjaar minder wordt, terwijl de toename van de proportie "chronisch zieken" in de midden- en hoogste status-categorie zo"n tien jaar later optreedt. Arbeidsomstandigheden kan men overigens niet geheel verantwoordelijk houden voor dit verschil; het geldt voor mannen en voor vrouwen.

In tegenstelling tot hetgeen sommige auteurs vinden en stellen, troffen wij bij werklozen niet een slechtere gezondheid aan, wèl meer klachten van functionele aard. Ditzelfde resultaat (geen slechtere gezondheid dan men op grond van een combinatie van leeftijd, geslacht en sociale status kan verwachten) vonden wij voor personen wier huwelijk door scheiding of dood is ontbonden. Ook in deze groepen zijn de scores op een lijst met lichamelijke klachten vooral terug te voeren tot malaise- en spanningsklachten.

Wij vonden nièt (en dat is ook een resultaat) dat huishouden en/of beroepsarbeid voor gehuwde vrouwen op zich zelf met verhoogde klachtenscores gepaard zouden gaan. Huisvrouwen uiten niet categorisch meer psychische klachten dan werkende vrouwen of omgekeerd. Vrouwen met kleine kinderen voelen zich niet categorisch onprettiger dan vrouwen met grotere kinderen of zonder kinderen.

Wel blijft de vraag of er binnen deze groep omstandigheden aan te wijzen zijn waaronder meer en minder klachten optreden, maar - we hebben het al eerder gesteld - daarover moet nader onderzoek plaatsvinden. 


\subsection{Suggesties voor verder onderzoek}

De belangrijkste suggestie voor nader onderzoek, die wij doen, is in de richting van een studie in een flink aantal huisartspraktijken. Oliemans alsmede Van Es en Pi jlman herhaald, maar dan nu met de kennis en methoden die ons bijna vijttien jaar later ter beschikking staan.

Wil men voldoende huisartsen bereid winden aan een dergelijk project mee te doen, dan dient men hen voor de extra inspanning te belonen. Bovendien is het onze ervaring, dat zelf-registratie in de huisartspraktijk zonder meer onbetrouwbaar is. Men zal dus gedurende de onderzoeksperiode een hulpkracht in de praktijk dienen te installeren. Dit alles maakt een dergelijk onderzoek zeer kostbaar. Men dient echter de kosten ervan te besclhouwen als behorend bij het (in het algemeen in vele andere opzichten) goedkope abonnementsysteem, dat nu eenmaal als nadeel heeft dat er niet 'vanzelf' gegevens uit naar voren komen.

De tijd voor een continue, geautomatiseerde registratie is nog niet daar. Wil men niet tot in lengte van dagen zijn oordelen over hetgeen in de huisartspraktijk gebeurt baseren op hetzij verouderd, hetzij incidenteel onderzoek, dan dienen er wat de financiering van een dergelijk project betreft knopen door te worden gehakt. Een belangrijke vraakgstelling in zo'n onderzoek zal moeten zijn wat nu precies het effect is van meer terugbestelcontacten in kleinere praktijken. Wordt er inderdaad meer 'zelf gedaan" en inderdaad beter gereageerd op aangeboden klachten van functionele aard, of zijn er niet of nauwelijks effecten op de gang van een patient door de gezondheidszorg te verwachten.

Opzet van een dergelijk onderzoek zal bovendien tot gevolg hebben dat onderzoekers hun energie niet behoeven te besteden aan het werken met in veel opzichten suboptimaal materiaal, van welk soort onderzoek dit proefschrift een voorbeeld is. 


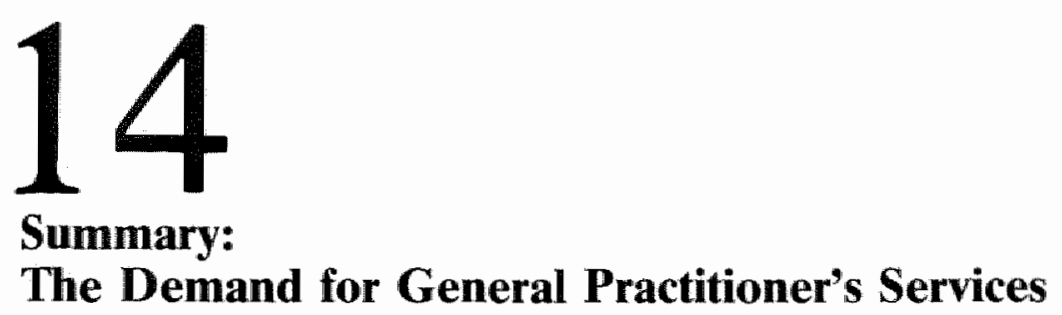

\section{Introduction}

If one is interested in the analysis of the utilization of medical services in general and the general practitioner's services in particular, then a study carried out 'lege artis' should contain both variables on the demand side (the patient) as well as on the supply side (the practitioner and his practice).

The only type of study that meets this purpose is a so-called 'practice analysis' where per general practice is studied how characteristics of patients on the one side and the properties of doctors and their practice on the other side influence utilization. Such a study is very expensive and complicated because creating enough variation on the supply (practitioner's) side means that a minimum of 50 - 100 practices have to be studied. Besides, the usually scant information about the patient and his family available from the practitioner's medical record has to be supplemented by information collected by questionnaire. In the Netherlands no such study exists till this moment.

On the one side information about the utilization of medical services on the demand (patient's) side has been and is collected in 'household surveys', on the other hand only scattered information from practice studies (one, two, three doctors) exists, while information from the Dutch National Morbidity Survey in 1969 per practice unfortunately is not available anymore.

That is why we split our study in two parts. In the first part (called "Complaints") the demand side is studied based upon household surveys (the Life Situation Survey 1977, collected by the Central Bureau of Statistics and the Dutch Socio Cultural Planning Office). It concentrates on the question why people complain about their health. In the second part ('Utilization') the focus is on the supply side. Here we have been using data from the English health care system, collected per practice in the 2 nd National Morbidity Survey in England and Wales (by permission of $\mathrm{dr}$. 
Donald Crombie from the Research Unit of the Royal College of Generalpractitioners in Birmingham).

\section{Pari I: Complaints}

A logical consequence of the introduction would not be a part called 'Complaints' and a part called 'Utilization', but a division into 'Demand' and 'Supply'. Why is this not the case? Well, all population surveys that aim to analyse the utilization of medical care; particularly, elegantly and sophisticatedly designed as they may be, come to one conclusion: "people visit their doctors onlly if they have complaints about their health'. The title of David Mechanic's article (Mechanic, 1979): "Correlates of physician utilization. Why do so many major multivariate studies of physician utilization find trivial psychosocial and organizational effects?', is significant in this respect.

Mechanic's diagnosis of this painfully true observation (think of all the money that those "major multivariate studies' cost) is that "complaints" or rather "a score on a list of physical complaints' is not a valid measure of a person's health status, but rather an indication of psychological distress. We will return to this later. Mechanic points out how those population surveys have been based upon the classification of factors influencing physician's utilization into a "predisposing" -, "enabling" - and 'need' categorial system; a classification introduced in the American health care sector by Ronald Andersen (1968)* After reading most of the publications of Andersen and his collegues (Andersen 1969, Kravits and Anderson 1975, Andersen and Aday 1978, Andersen et al, 1977) we concluded that the 'predisposing-enablingmeed classification scheme' was originally not intended to produce a causal analysis of the utilization of medical care, but to evaluate the efficiency of the allocation of health services. Andersen's most important book has as title "Equity in Health Services" and as subtitle 'Empirical Analysis in Social Policy'. Health services have been allocated efficiently if the need for health care defines the use of health services and not factors as 'income', 'cultural deprivation', etc.

We could answer Mechanic's question 'why do those major multivariate studies etc.' with the statement 'because those major multivariate studies were designed to produce (scientifically) trivial results'. Unfortunately Andersen confused the original aim of his study by using the same scheme in a causal analysis of utilization (Andersen and Aday, 1978) where a causal sequence is introduced in his originally unrelated categories of variables. This causal sequence has been adopted by Kohn and White in their international health care study (Kohn and White, 1976) and is popular until today (Van Vliet en Van de Ven, 1982, Kronenfeld 1980). And indeed all those studies show the scientifically trivial result that the need for health care, indicated by a list of physical complaints, is the major determinant of the use of

* In the Netherlands at similar classification was used by Philipsen $(1963,1969)$ for the analysis of absence of work in industrial settings. 
health services. Well, here the empirical part of our study starts. As it is true indeed that all utilization studies start and end with the above mentioned establishment we had better concentrate upon the explanation of the scores of physical complaints. Thus our utilization-model counts two stages: firstly we try to explain variations in complaints and in a second stage we will explain the utilization of the general practitioner's services.

\section{The ambiguty of physical complaints}

Here we arrive at Mechanic's second observation: the ambiguity of physical complaints. Do they measure 'health status', 'psychological distress' "neuroticism' or does perhaps a list with physical complaints contain a mixture of all those possible interpretations? Chapter 4 of our thesis is dedicated to this subject. We could discern three unrelated approaches in this area. Firstly there is a predominantly medical tradition of producing questionnaires for anamnestic purposes. Secondly there is a strong and rich tradition to consider functional physical complaints as a vital indication of the "neurotic personality" (Eysenck, and in the Netherlands, Wilde $(1963,1970)$ - whose Amsterdam Biographical Inventory contains a list of nonsomatic and somatic complaints as indication of neurotic lability -, in England Goldberg with his General Health Questionnaire for the detection of psychiatric illness), and thirdly we find authors who consider the utterance of complaints as an indication of 'stress' (Dirken, 1967).

Our conclusion is that a person's score on a list with physical complaints, no matter whether the intention was to measure health status, neurotic lability or distress, is a vector of bad health and psychological distress or neurotic lability. The problem is, one cannot tell from the summated rating which combination of the two beforementioned components applies in each case. So the second problem we laad to solve in our study (the first was to escape the danger of the trivial results), was to split the commonly used list of complaints into an indicator of 'bad health' and 'psychological distress'. Fortunately the Life Situation Survey 1977 (LSS-77) contained both an indicator of chronic illness (an inventory of 26 categories of chronic diseases), and an indicator of nonsomatic neurotic lability ( 10 items from the above mentioned Amsterdam Biographical Inventory) (ABll-N) and a 21 items list with physical complaints designed as an indicator of stress. (Dirkens Questionnaire for Research into the Experienced Health status): the QREH is in Dutch the 'VOEG'. With those three measures of the phenomenon of physical complaints a model for their explanation could be designed. Schematically our model looks as follows: 
Figure 14.1. Schematic model for the explanation of physician utilization in population surveys.

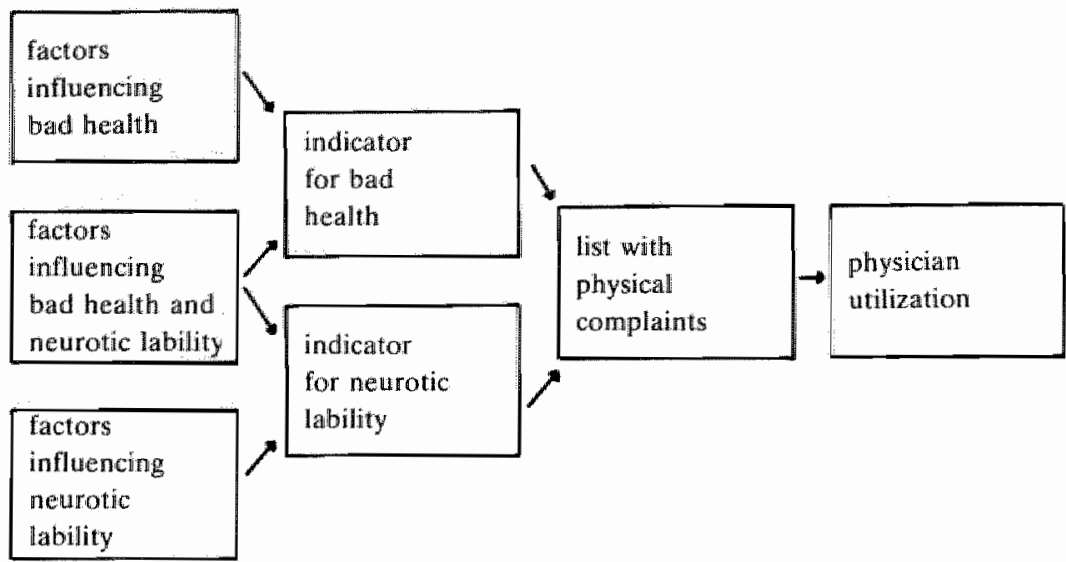

The model contains variables that influence a person's health status, variables that influence a person's neurotic lability and variables that influence both. Health status (measured as the absence or presence of chronic illness) and neurotic lability influence in their turn a person's score on a list of physical, somatic complaints, the major predictor of physician utilization. We intended to design a 3-stage model and to estimate in the first and second stage successively chronic illness, neurotic lability and physical complaints. At this point in our argument we arrive at chapter 5 , where we describe the results of our quest for results of research into general factors that influence health status and factors that influence neurotic lability. In our quest we limited ourselves to the influence of rather rough categories of variables. We were not interested in the connection between related indicators of a general feeling of non-wellbeing but we rather looked for biographical and contextual variables.

\section{Expectations and Results}

We selected 10 variables from our sources in literature. Four were supposed to influence health status (i.e. chronic illness), viz:

1. Age (the older the more chronically ill)

2. Sex (women more chronic iliness than men)

3. SES (socio-economic status) (the higher a person's status the better his health)

4. Unfitness to work (persons who lost their work and come under the Disability Act are supposed to have a chronic illness).

We also found that persons from the lowest status category and aged between 35 and 44 years had a worse health than could be expected from a linear combination of status and age. So we introduced an interaction term in our estimation. 
For neurotic lability we expected to find similar results with respect to Sex, SES and Unfitness to work. (Women more neurotic complaints than men, manual workers more than clerical workers or higher strata in the status hierarchy and persons without work due to chronic illness more neurotic complaints than others).

For 'ages we expected that the younger generation would utter more neurotic complaints than the elder generation, as "complaining' has become more and more tollerated during the past decades. We also expected a relation between neurotic lability and marital status (we expected people whose marriage had been dissolved by divorce or death of the partner to have higher scores than married or unmarried persons). Divorce and widowhood were considered as suboptimal, more or less chronically depressing conditions among which we also counted 'unemployment' and chronic illness. The addition of the last variable complicates our model because it presupposes a relation between the dependent variables of our first stage (chronic illness and neurotic lability). Finally we included three variables in our model as indicators for the (normative) integration of an individual. Firstly the integration in a normative system (religiousness), secondly the integration in the direct surroundings (neighbourhood) and thirdly the size of the community. In table 14.1 all significant relations of the beforementioned independent variables and our indicator for chronic illness and neurotic lability are shown. The t-statistics show the strength of the relationship.

Two results are striking. At first the low proportion of explained variance. Only $12 \%$ in chronic illness and a poor $7 \%$ in neurotic lability is explained by the 11 independent variables. Technically spoken the results are not very hopeful, materially however, there are some interesting things to show. The health of older people is worse than the health of the younger. But older persons indeed complain less than younger ones. This explains why some authors do not find an expected relationship between age and physical complaints. A low socio-economic status is connected both with a worse health and with more non-somatic neurotic complaints. The latter also goes for the marital status variables. Divorced people show higher scores than widowed persons than married or non-married persons from 15 years and older. Unemployment is a source of complaints but not of worse health. Unfitness to work due to disability or chronic illness is also connected with neurotic complaints. Religious and integrated persons and inhabitants of smaller communities complain less than non-religious, badly integrated persons and inhabitants of towns and cities. We also found (what we do not show here to save space) that a chronic illness is connected with neurotic complaints.

In the second stage of our estimation we found the expected very strong relation between the list of physical complaints and the two versions of chronic illness and neurotic lability computed according to the results in table 14.1 .

Physical complaints indeed are a vector of bad health and neurotic complaints and the two components can be distinguished analytically. The low proportion of explained variance however, frustrates our original intention to test a three-stage 
Table 14.1 Estimation results chronic illness and neurotic lability in the Life Situation Survey 1977, The Netherlands. $n=4157$. Persons 15 years and older. Multiple regression, ordinary least squares, $\mathrm{B}$-coefficients and $\mathrm{t}-\mathrm{statistics}$ printed when $\mathrm{p}<.05$.

\begin{tabular}{|c|c|c|c|c|}
\hline & \multicolumn{2}{|c|}{$\begin{array}{l}\text { Chronic illness } \\
\text { Chronic illness } \\
(1=\text { yes })\end{array}$} & \multicolumn{2}{|c|}{$\begin{array}{l}\text { Neurotic lability } \\
\text { Neurotic lability }\end{array}$} \\
\hline & $\begin{array}{l}\mathbf{B} \propto \text { coeffi- } \\
\text { cients }\end{array}$ & $\begin{array}{l}\text { tistatis- } \\
\text { tics }\end{array}$ & $\begin{array}{l}\text { B-coeffi- } \\
\text { cients }\end{array}$ & $\begin{array}{l}\text { t-statis- } \\
\text { tics }\end{array}$ \\
\hline Age (in years) & .0078 & 18.40 & -0042 & 2.64 \\
\hline $\operatorname{Sex}(1=\operatorname{man} / 2=\operatorname{woman})$ & .060 & 4.28 & .48 & 8.43 \\
\hline SES $(1=$ high $/ 3=$ low $)$ & .031 & 3.13 & .21 & 5.63 \\
\hline $\begin{array}{l}\text { Dummy wariable: } \\
\text { Age } 35-44 \text { yrs/Status Jow }\end{array}$ & .075 & 2.62 & & \\
\hline Unfitness to work ( $1=$ yes $)$ & .33 & 7.89 & 1.17 & 7.45 \\
\hline Unemployed $(1=$ yes $)$ & & & .84 & 3.96 \\
\hline Divorced $(1=$ yes $)$ & & & 1.02 & 4.45 \\
\hline Widowhood ( $1=$ yes) & & & .52 & 4.50 \\
\hline $\begin{array}{l}\text { Number of inhabitants of } \\
\text { community (logarithmic } \\
\text { transformation) }\end{array}$ & & & .057 & 3.02 \\
\hline $\begin{array}{l}\text { Integration in neighbour- } \\
\text { hood }(1=\text { weak } / 9=\text { strong })\end{array}$ & & & .058 & 5.02 \\
\hline $\begin{array}{l}\text { Religiousness ( } 1=\text { religious } \\
3=\text { no reltigion) }\end{array}$ & & & .099 & 2.67 \\
\hline Constant & .21 & 10.77 & 11.93 & 7.86 \\
\hline Estimation parameters & & $=12$ & & $=.07$ \\
\hline
\end{tabular}


model wherein utilization would be estimated in the third stage. The path from socio-cultural circumstances to physical complaints apparently is more complicated than we supposed.

\section{Part II: Physician utilization}

In the second part of our study we direct our attention to the supply side; the influence the doctor and the way he organizes his surgery exert upon the number of doctor/patient contacts. We consider physician utilization as a function of demand and supply, and as our emphasis till now laid upon demand characteristics, we will now focus upon the influence of supply qualities. As we told before, unfortunately in the Netherlands no complete practice study has been carried out. Neither exists routinely collected data, because general practitioners are paid a capitation fee for about $70 \%$ (the $70 \%$ with the lowest income) of their practice population. The other $30 \%$, the private patients, are either privately insured or not insured at all for the services of a general practitioner. So we had to move towards our aim indirectly. Firstly we tried to find practice studies in comparable health care systems. We found what we were looking for in the Second National Morbidity Survey in England and Wales. Secondly we tried to connect supply characteristics (i.e. characteristics of the health care system) as contextual variables with the records of the individuals of the Life Situaton Survey 1977. The residence of the respondents in the survey was known, so we could compute variables for this community of residence (number of general practitioners per capita, number of hospital beds etc.) on an aggregated level and distribute these variables to all the respondents of the community.

\section{The 2nd National Morbidity Survey in England and Wales}

The Dutch and the British health care system are in some respect comparable as far as primary care is concerned. For $70 \%$, the publicly insured part of his practice population (his 'list') the Dutch general practitioner gets a capitation fee* "He has a list of patients (in any way of publiclly insured patients, but as a rule also of private patients) and the entrance to the secondary medical care is regulated via the general practitioner. Neither publicly insured nor privately insured patients are allowed to consult a medical specialist without being referred by the general practitioner. Here all resemblance stops: in Holland medical specialists usually practice as free entrepreneurs and are paid fee for service. This in (striking) contrast with the British

- A very crude and uncomplicated one. It consists of four parts: a fee for all patients (1), a remuneration of the practice costs for the first 1800 patients (2), a small remuneration of the practice costs for all patients (3) and a contribution to the doctor"s old age pension for the first 2000 patients (4). For 1981 the amounts are: Dfl. $50,24(1)+$ Dfl. $32,76(2)+$ Dfl. $2,73(3)+$ Dfl. 8,49 (4).

The remuneration for the practice-costs are irrespective the real costs; it is paid to all practitioners. 
system where medical specialists generally are employed by hospitals. For primary care, however, the two health care systems are more or less comparable, so we were glad to be able to collect data for each practice that participated in the 2nd National Morbidity Survey.

For each practice (60 practices in all) we collected the following figures:

Per age/sex group

(M/F, 0-4 yrs, 5-14 yrs, 15-24 yrs, 25-44 yrs, 45-64 yrs, 65-74 yrs, 75 yrs a.o.)

a. the number of episodes including episodes that started outside the practice and recurrent new episodes of existing illness (new cases during the year the mor bidity has been counted)

b. the number of episodes already existing before the morbidity counting started (mostly chronic illness)

c. the total number of consultations (divided into: at the surgery or home visits)

d. different types of referrals (in-patient, out-patient, investigation and other).

Per practice was known:

1. the number of principals

2. the list size

3. a rurallurban indicator

4. the practice location. From this location we derived, with the help of the Institute of Health Services Administrators, the distance between the practice residence and the nearest general medical hospital.

For a supply study the number of practice characteristics is very limited, but as we explained, even this limited set of data does not exist in Holland. For the purpose of our analysis we divided the consultations in two parts. We distinguished patientinitiated contacts and doctor-initiated contacts. The first category contained all new and recurrent episodes, the second category the total number of consultations minus the episodes of the first category. We considered contacts for chronic illness as doctor-initiated (although we analyzed them separately either).

We corrected the numbers of patient and doctor-initiated contacts for the influence of the age/sex distribution of the practice population by computing expected frequencies on the base of the frequency distribution by age/sex group for all practices together and constructing per practice the differences between the number of patient and doctor-initiated contacts expected and found on the base of the specific age/sex distribution of the practice population.

\section{Results}

Firstly we looked at the relation between list size (i.e. number of patients per principal) and the two types of contacts and did not find a thing. There were two disturbing factors. Firstly there was one general practitioner with a very large list and many more contacts than we had expected from the age/sex distribution of his 
practice (and our method of analysis (correlation analysis) is very sensitive for extreme values), and secondly there was a disturbing influence of the practice organization. Solo-doctors tended to have a somewhat larget list, and somewhat more contacts than practices with two or more principals. After separating soloists and partnerships "we found (see figures 10 1-4 on page 123-124) interesting and interpretable results. List size does not have any influence on the difference between the found and expected number of patient-initiated contacts but definitely influences the difference between found and expected doctor-initiated contacts. This goes both for solo practices and for partnerships, the latter group generally having somewhat less patient- and doctor-initiated contacts than one would have expected on the base of the age/sex distribution.

The results of our analysis (carried out as a multiple regression analysis with list size, type of practice and practice location as independent variables) are shown in table 14.2 .

Table 14.2.:Multiple-regression, $B$-coefficients and $t$-values (between brackets) of list-size, type of practice, and practice location with the differences between the number of patient-initiated contacts, the number of doctor initiated contacts and the number of home visits found and the number expected on the base of the age-sex distribution of the practice population. T-values are italic if $p<.05$. Source: 2 nd National Morbidity Survey in England and Wales 1970-1971, n $=59$.

\begin{tabular}{llllll}
\hline List & type of & practice & hospital & hospital constant & $\mathrm{R}^{-2}$ \\
size & practice & location & in com- & $>10$ miles \\
& $(1=$ solo $)$ & $(1=$ urban $)$ & munity & from com- \\
& & & & munity &
\end{tabular}

\begin{tabular}{llllcllll}
$\begin{array}{l}\text { Df patient- } \\
\text { initiated } \\
\text { contacts }\end{array}$ & -.015 & 441.67 & 407.20 & 65.01 & 747.03 & -591.84 & .111 \\
& $(.09)$ & $(2.22)$ & $(1.51)$ & $(.24)$ & $(1.97)$ & $(1.12)$ & \\
$\begin{array}{l}\text { Df doctor- } \\
\text { initiated }\end{array}$ & -.668 & 746.76 & 84.54 & -179.94 & -54.55 & 1574.56 & .156 \\
contacts & $(3.05)$ & $(2.85)$ & $(.24)$ & $(.50)$ & $(.11)$ & $(2.27)$ & \\
$\begin{array}{l}\text { Df home- } \\
\text { visits }\end{array}$ & -.077 & -43.96 & -442.38 & 99.18 & -72.77 & 462.58 & .108 \\
\hline
\end{tabular}

Patient-initiated contacts are only influenced by type of practice; doctor-initiated contacts by type of practice and list size; home visits only by practice location. In rural areas more visits are found than would be expected on the base of the age/sex distribution. This is an interesting result; the decision office/home visit apparently is only influenced by the location of the practice and is not used as a decision to reduce work-load caused by list-size or practice-organization. 
Further analysis of the influence of type of practice (why should soloists have more contacts than partnerships) by comparing the number of patient-initiated contacts per age/sex group (see table 10.3) showed that the differences were found in relatively healthy groups (men from $5-24 \mathrm{yrs} /$ women $5-14 \mathrm{yrs}$ ) which points to a probably lower threshold in solo practices.

\section{Substitution between primary and secondary medical care}

We intended to have our contact-analysis followed by an analysis of referral frequencies. From our previous research in this field (Posthuma and Van der Zee 1977, 1978) we expected a strong relation between the distance from practice to the nearest general hospital and the number of in- and out-patient referrals. In the Dutch health care system distance and number of medical specialists and hospital beds are major predictors of differences in referral- and admissionmrates on aggregated (community) and individual (general practice) level. We wanted to test the following model (in a two-stage estimation).

Figure 14.2. Schematic representation of a model for the explanation of doctor-initiated contacts and referrals in general practice

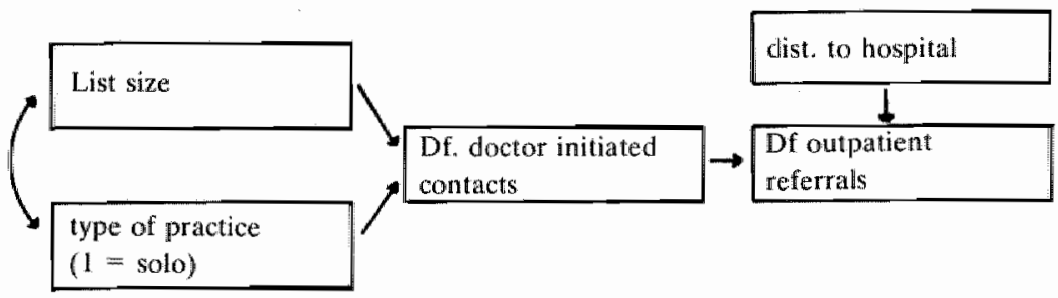

We expected substitution between primary and secondary care to take place between doctor-initiated contacts and referrals as we considered the possibility to refer a patient as one of the means a general practitioner can use to reduce this workload. So we first estimated the number of doctor-initiated contacts (or rather the difference between the number found and expected) from the variables in table 14.2 and tried to test a relation between this computed variable and the distance from the nearest general hospital on the one hand, and the number* of in-patient and oul-watient referrals and referrals for investigation on the other hand. The results are striking for an investigator deformed by being employed in a health care system where medical specialists are paid a fee for each service.

* Here 100, not the exact number but the difference between the number expected and found was computed. 
No negative relation was found between the distance to the nearest hospital and any of the referral rates, but even a positive relation between in-patient referrals and distance; the farther from the hospital the higher the number of acute admissions. In our discussion of the results we suggested several possibilities:

1. Our distance measure was too crude and should have been completed by regional data on the number of hospital beds and medical specialists per capita. In the Dutch health care system, however, the influence of distance on referral rates is much stronger than the influence of hospital beds and number of specialists per capita.

2. It also might be the case that secondary health care is (or rather was in 1970/71) more efficiently allocated in England and Wales than in our country; a result of great political importance if it were true indeed. More comparative research in this field might be useful.

\section{Urilization in the Life Situation Survey" 1977.}

As we promised, our last chapter (11) has been dedicated to the analysis of utilization frequencies in the Life Situation Survey, 1977. We already announced that we should add to the data of individual respondents some characteristics of the health care of their community of residence (number of general practitioners per capita, number of medical specialists per capita, distance to the nearest general medical hospital, difference between the number of surgeries and the number of general practitioners per capita).

The latter indicator was meant to measure the degree of concentration of medical practices. We also added some extra demand variables to the existing set, namely those variables that exert influence upon utilization but not via chronic illness, neurotic lability or physical complaints. The variables were a dummy variable for women in the age 15-44 yrs (with regular visits for anticonception), two variables representing acute illness (one if the respondent had been in bed or at home less than a week but more than a day in the past three months and one if the respondent had been ill between one and two weeks). Finally we added an insurance variable that got the value ' 1 ' for private patients. Together with the three dependent variables in the complaint analysis and all the independent variables of this analysis we included the above mentioned variables in our analysis of physician utilization with the following result:

Of the (11) independent variables in our complaints model only Age had a significant relation with utilization. The other independent variables exerted their influence via our measure of health status and neurotic lability. From the extra demand variables women 15-45 yrs of age and acutely ill persons had a greater chance upon a contact with the doctor. The insurance variable had no indlependent influence on physician utilization. Our supply side variables did not contribute to the proportion of explained variance. We already expressed our fear that the aggregation level would be too high for our purpose, and this indeed proved to be true. It 
proved to be not useful to connect the average number of general practitioners per capita with the medical consumption of an individual person. The size of the list of a persons practitioner could do perhaps, but not an average figure. The most important conclusion of this chapter is that the analysis of physician utilization based on surveys, that usually do not contain supply variables is not a fruitful affair. Supply wariables do exert influence, as we saw in our analysis of the 2 nd National Morbidity Survey, but have to be measured in practice studies and not in population surveys. 
Hoofdstuk 1

1. Het betreft hier een voortzetting van de serie 'Tussen le en 2 e echelon', waarvan het le en. 2 e deel in 1977 en 1978 verschenen. (Posthuma en Van der Zee, 1977, 1978). In deze serie staan 'verwijscijfers' centraal en worden variaties in werwijscijfers tussen gemeenten (deel I) en huisartspraktijken (deel II) bestudeerd. Ook wordt (in deel I althans) bezien welke factoren het percentage ziekenhuisopnamen (gegeven het verwijscijfer) en de gemiddelde verpleegduur (gegeven het verwijs- en opnamecijfer) beinvloeden. Het ligt in de bedoeling de analyse op macroniveau binnen afzienbare tijd te herhalen na het verschijnen van de dissertatie van Posthuma: 'Collectivisering van de Gezondheidszorg'.

2. In onze heranalyse vam het materiaal wan Van Es en Pijlman (Posthuma en Van der Zee, 1978,46 ) vonden we het getal wan 4.5 per 100 contacten.

3. Bedoeld wordt: verwijzen in kwantittatieve zin. Voor een huisarts kan een verwijsbeslissing wel degelijk de belangrijkste beslissing zijn die hij die dag genomen heeft.

4. Een uitzondering vormt de in 1980 gestarte 'Gezondheidsenquête' van het Centraal Bureau voor de Statistiek. In deze enģtête wordt onderscheid gemaakt tussen contacten op initiatief van de patient en contactem op initiatief van de huisarts. Er worden ook vragen gesteld over het soort huisartspraktijk waarbij men is ingeschreven of van welke diensten men gewoonlijk gebruik maakt. Bij het afronden wan het eerste deel vin dit proefschrift (begin 1981) waren echter de gegevens uit deze enquete mog niet beschikbaar.

5. Het verschil met het Nederlandse systeem zit hem in de veel grotere mate wan specificatic van de honorering. Zo zijn er bijvoorbeeld verschillen in abonnementsgeld voor bejaarde en hoogbejaarde patienten. Er is ook een leeftijdistoeslag voor oudere kuisartsen en in het kostendeel wordt niet een forfatair bedrag aan iedere huisants ter beschikking gesteld, maar worden (gedeelten van) werkelijk gemaakte kosten gerestitueerd. Onderhandelingen ower wijzigingen in het systeem hebben een flexibeler en meer inhoudelijk karakter dan de onderhandelingen te onzent. 
6. Een gegeven dat op zich weer geen goede rwaat is voor de neiging van de huisarts zijn patiënten te verwijzen. Verschillende soorten verwijzingen (op initiatief van de huisarts, initiatief specialist) zijn in het bruto verwijscijfer niet wan elkaar te onderscheiden. Een goede operationalisering van de 'verwijsneiging' van de huisarts is het aantal verwijzingen-op-initiatief-wan-de-huisarts betrokken op het antal contacten tussen huisarts en patiènt. Deze maat blijkt tussen huisartsen in vergelijkbare omstandigheden te differentiëren en ook tamelijk stabiel te zijn (zie Bensing en Verhaak, 1980).

\section{Noten deel I \\ Klachten}

1. De oorspronkelijke witgave van de rapporten maakt enige bibliografische capriolen noodzakelijk; de rapporten zijn zonder expliciete vermelding van auteur, datum en uitgever gepubliceerd. We zullen ze in het vervolg vermelden als Nuyens e.a., 1979. De bibliografische annotatie luidt: Nationaal Onderzoeksprogramma in de Sociale Wetenschappen wan thet Koninkrijk België, project Eerstellijns Gezondheidszorg, Diensten van de Eerste Minister, programmatie van het Wetenschapsbeleid, zonder jaartal, zonder plaats.

2. Hoe Aakster precies te werk gaat is niet goed na te gaan. Hij trekt 2367 adressen (of 2362 - zie p. 80, 81). Per subcategorie werd het aantal benodigde respondenten per leeftijd en geslachtscategorie vastgesteld - maar hoe de interviewers per 'adres' uitmaakten wie van de huisgenoten moest(en) worden ondervraagd wordt niet beschreven. Het is niet uit te maken of per huishouden één of meer individuen zijn benaderd.

3. Dat is niet helemaal correct. Cassee vraagt, blijkens zijn vragenlijst, wèl naar klachten in gezondheidsbestand d.m.w. 'open' vragen. Hij gebruikt dit materiaal echter aergens in zijn analyse.

4. De nadruk ligt op het woord 'kennelijk'. Op zichzelf zou het best mogelijk en plausibel geweest zijn als andere factoren een invloed op de vraag naar diensten van de huisarts hadden gehad, buiten de gezondheidsklachten, maar dit is, iedere keer opnieuw, niet het geval.

5. Ware Mechanic econoom en geen socioloog geweest dan had hij zich met evenveel recht kunnen afvragen waarom het goed 'gezondlheidszorg' zo weinig gevoelig is voor economische factoren zoals de prijs van het goed.

Een uitkomst als: mensen gaan alleen naar de dokter als ze iets mankeren is voor een econoom zeker niet triviaal; hij moet hieruit concluderen dat het goed niet prijsgevoelig. is.

6. Deze mogelijkheid is wellicht iets te snell terzijde geschoven. Zie bijvoorbeeld hoe het door Cassee ontwikkelde begrip 'traditioneel magische ziektebenadering" empirisch is gefundeerd: de totaalindex is samengesteld uit subschalen waarvan de hoogste onderlinge samenhang een product-moment correlatie van . 46 is en de gemiddelde samenhang . 32 bedragt (Cassee, 1973, 25). Cassee vermeldt ook wijselijk voor de totale index niet de hoogte van de daar gebruikte betrouwbaarheidscoëfficiënt.

Ook het fameuze theoretische begrip "lay referral system", het lekenverwijssysteem, geeft aanleiding tot enige scepsis. In het grote Belgische onderzoek van Nuyens e.a. - een 
uitnemend voorbeeld van een onderzoek waar veel grootse sociologische visies stukiopen op het simpele gegeven dat mensen de dokter slechts raadplegen als ze door een stoornis in hun gezondheid worden getroffen - treft men in deel $1 \mathrm{H}$ een hoofdstuk over het lay referral system aan (deel i H-hst. $\mathrm{II}, 227-247$, tabellen deel $1 \mathrm{G}, 224,230,231$ ). Uit dit hoofdstuk blijkt dat: 'slechts weinig respondenten een beroep doen op meer dan es n persoon uit hun lay referral netwerk (...) en dat voor $83.2 \%$ wan de klachten de echtgenote of een ander familielid geradpleegd wordt (deel $1 \mathrm{H} ; 232$ ); 1198 van de 1570 respondenten (ongeveer driekwart) raadpleegt slechits én persoon: in $83 \%$ van de gevallen is dit ook nog een familielid (zie tabel 6.9. deel 1G, 231). Het komt ons voor dat bij de aanschaf van een ijskast een omvangrijker netwerk wordt geraadpleegd zonder dat in deze sector van consumentengedrag een bijkans mytisch 'lay referral' begrip is ontwik. keld, al zal de adspirant-koper zich een even groot leek in het ijskastwezen voelen als met betrekking tot zijn gezondheid.

7. Ter voorkoming van misverstanden dienen we te melden, dat McKinlay's kritiek hier voor de volledigheid en neutraal is weergegeven. Een deel van zijn kritiek is voor de Nederlandse situatie van het ogenblik niet meer van toepassing. Van der Ploeg (1980) onderzocht op welke wijze 'veel-en-weinig-gebruikers' in de buisartspraktijk qua persoonlijkbeid zouden verschillen; Mootz (1981) legde de nadruk, in een typisch kleinschalige studie, op de invloed van de sociale omgeving van chronische patiënten op hun medische consumptie. Nevenproducten van 'routinely collected statistics' worden zelden meer klakkeloos in sociaal wetenschappelijk onderzoek gebruikt. Ook gaan we hier niet op de vraag in of McKinlay's suggesties alle even zinvol zijn. Mechanic's kritiek op de bevolkingsstudies is voor ons doel relevanter.

8. Zoals in noot 5 al is gesteld is dit resultaat niet theoretisch triviaal, integendeel, het gaat hier om een consumptiegoed waarop inkomens- en prijsfactoren blijkbaar niet van invloed zijn; het zou ook heel goed het geval kunnen zijn geweest dat andere dan met de beleving van de gezondheid samenhangende factoren een invloed op frequenties van doktersbezoek hadden uitgeoefend. Bijvoorbeeld in het geval dat de ene persoon met veel gezondheidsklachten wel en de andere de dokter niet bezoekt; maar in geen enkele studie zijn aanwijzingen voor een dergelijke opvatting te vinden.

Op empirische gronden moeten we dus besluiten dat het gebruik van partielle correlaties, waarin relaties tussen dokersbezoek en mogelijke verklarende factoren bestudeerd wor * den met constant houden van gezondheidstoestand, zinloos is.

9. Andersen \& Aday, 1978, 534. 'Brieffy, is assumes that a sequence of conditions contribute to whether or nor people use services and the volume of services they consume. Use is posited to be dependent on, first, the predisposition of the individual to use services as suggested by demographic and social characteristics and beliefs about health serwices (i.e., predisposing variables); then this ability to secure services as indicated by his own personal resources and the availability of health services in his community of residence (i.e., enabling variables); and finally his state of illness as self-perceived and also as evaluated by the practirioners who treat him."

10. Het is overigens curieus dat Andersen met enkele medewerkers (Andersen e.a., 1977) een artikel publiceerde met de titel 'psychologically related illness and health service utilization'. In dit artikel toont hij op zijn bekende gedegen wijze aan dat het gebruik van voorzieningen in de gezondheidszorg (vooral doktersbezoek en medicijngebruik) bij psychiatrische en psychosomatische aandoeningen duidelijk hoger is dan bi.j andere 
klachten. Hij trekt echter nergens de conclusie dat dit van belang zou zijn voor de interpretatie van de resultaten van ajn eigen daarwoor gepubliceerde onderzoekingen. De enige aanbevelingen in het artikel hebben betrekking op een betere afstemming tussen somatische en geestelijke gezondheidszorg.

11. Correlate VOEG-ABV-N = 696; VOEG-ABV-NS = 839 (Dirken, 1967, 175). Correlatie DV.ABV - N (bij 3 populaties) resp. $.82, .92$ en $.87 ;$ DV-ABV-NS resp. $.64,38$ en 45 (Appels, 1975, 79).

12. Appeis vervolgt dit citat met de zin "Hierop zall in een aparte publicatie worden ingegaan". Deze publicatie heeft Appels geschreven onder de titel "Wat is neuroticisme'; ze is echter jammer genoug niet voor publicatie geaccepteerd. In een uitvoerige analyse van Wilde's proefschrift en de sindsdien uitgevoerde exercities met de ABV, komt hij tot de conclusie dat de "zachte" aanbieding van de neuroticisme-test (in nawolging wan Hofstee"s kritiek op de ABV (Hofstee, 1963) de mensen als het ware tot klagen uitnodigt. 'In de meewarige amosfeer van de neuroticismetest wordt de gelegenheid geboden te klagen, zich onflink voor te doen". Zich zo te presenteren wordt sociaal meestal weinig gewazrdeerd, maar des te interessanter en belangrijker is het wanneer mensen dat toch doen!" ..... Neuroticisme reflecteert de maatschappelijk weinig gewaardeerde geneigdheid om positief in te gaan op de kunstnatig aangeboden zachte atmosfeer van klagerigheid en tobberigheid (p. 6)"

Een atmosfeer, die volgens Appels, dok in de hulpverlening wordt gecreëerd. Dit zou een verklaring kunnen zijn voor de sterke samenhang tussen hulpvraag en neuroticismescore.

13. Volgens Wilde $(1970,13)$ is neurotische labiliteit (of neuroticisme) dat gemeenschappe lijke persoonlijkheidskenmerk dat bepalend is woor de waarschijnlijkheid dat een individu een zodlanig gedragzal vertonen dat hij onder én of meer van Scott's (in een publicatie van 1961 geformuleerde, JvdZ) researchdefinities valt; d.w.z.:
a. onder psychiatrische behandeling komt
b. met de justitie in anraking komt
c. de psychiatrische diagnose "neurose" verkrijgt
d. blijk geeft zich subjectief ongelukkig of insufficient te voelen
e. blijk geeft van objectieve symptomen (b.v. psychologische tests) die op neurose wijzen
$f$. faalt in dile verwerkelijking van $z^{\prime \prime} n$ eigen mogelijkheden.

14. In het Engelse taalgebied fungeen de door Goldberg (1972) ontworpen General Health Questionaire als een instrument ter opsporing van psychiatrische stoormissen. Dikwijls gebruikt in de huisartsprak tijk (Johnstone \& Goldberg, 1976, Marks, Goldberg \& Hillier 1979), echter zonder enige verwijzing nar hichomelitke aandoenimgen.

15. In hoofdstuk X\& H (Wilde, 1970,132-35) is de ABV afgenomen onder patiènten lijulend atan psychosomatische aandoeningen ( 25 patiènten met asthma bronchiale: 18 patiènten met dysmenorrhóea: 36 patienten met thinitus vasomotorica; 27 patienten 'Ijdende aan verspreide ziekten' en 34 patiënten $\$$ ijdend aan coronair trombose). In dit deelonderzoek zijin echter wlleen de totalscores voor de verschillende groepen met die van de ijkingssteekproef vergeleken. De NS-scores laat hij buiten beschouwing; hij gebruikt alleen de wiet somatische neuroticisme-score. Wilde's motto blijft: vermoed men "hichamelijke ziekte": gebruik alleen de ABV-N.

16. In de al eerder genoemde VOEG bereikt de verwarring zijn top, ondat Dirken met opzet de titel wan de vragewlijst een "medisch" tintje heeft gegeven. Hoewel Dirken postuleert 
dat de vragenlijst 'psychologische' stress meel, (Dirken's items zijn ook voot een groot deel uit de toxicologie afkomstig en voor een ander deel wil de Cornell Medical Index, Dirken, o.e., 87-88) is écn van de argumenten voor de geldigheid (Dirken, o.c., tabel 9 , 1.18, enkelvoudige validiteiten van VOEG-scores tegen medische diagnoses an anamneses), dat er en positieve correlatie bestatat tussen het oordeel van de bedrijfsurts over de gezondheidstoestand van degene die in de hoogste 2 decielen wan de VOEG vallen en de VOEG-score. De correllatie is het hoogst voor "neurotische symptomen' $(r=.663)$, maar ook voor objectief lichamelijke stoornissen (.246) en 'seriewze Klachten' op een anammeselijst woor hart-vatziekten $(r=.349)$.

Dirken zegt hierover: "Deze (vier) correlaties vormen een owertuigende bijdrage tot de validiteit van de VOEG (Dirken, o.c., 1.19)."

"Stress", "ziekte" en "neurotische labiliteitt" zijin ook in Dirken's onderzoek nauw met elkant verweven; met name Dirken's conclusie dat ook de correlatie tussen de hart/vat anamnese-lijst moet worden opgevat als een bijdrage tot de validiteit van de principieel aspecifieke VOEG, makkt een goed begrip erg moeilijk.

17. We spreken hier wel van "neuroticisme", het is echter de vraag of Wilde's oorspronkelijke begrip door Ormel niet te zeer is uitgehold. Wilde"s vragenlijst bevatte 47 items $(30 \mathrm{~N}-17$ NS - Wilde, 1970, 70). In het onderzoek 'medische consumptie' (Jessen e.a., 1974) zijn daaruit de 23 items met de zwaarste gewichten genomen (Ormel, 1980b, 154). Van deze 23 items worden door Ormel 14 geselecteerd op grond wan de lading op een (ongeroteerde) factoranalyse ( 14 met de hoogste lading). Van deze 14 zijn er 7 uit de ABV-N en 7 uit de NS afkomstig. Ormel telt echter de scores bij elkaar en beschouwt dit als en maat voor neturoticisme. Ormel's operationalisatie is wel erg wer verwijderd van Wilde's oorspronkelijke begrip.

18. Voor meetfout gecorrigeerde correlaties tussen $N 70, N 76$ en 77 zijn resp. 92 en .85 . De niet gecorrigeende correlaties zijn.70 en .64 . Voor NS70 (net NS76 en 77) zijn dit resp. .87 en .76 en (ongecorrigeerd) .60 en .55 .

19. Pais onderzoek wond slechts bij 99 patiënten plats; veel te weinig om de bruikbaarheid van de vragenlijst als diagnostisch instrument wast te stellen. Te grote bezwaren van de collegae internisten hebben het onderzoek ernstig belemmerd. (Pais, $\downarrow 977,103$ ). Pais' lijst differenticert tussen wel/geen organisch lijden. Het is niet bekend of dit op grond van een totaal-score gebeurt.

20. Dit zijn de items 'hartkloppingen' (N3 en klacht 4); moe, slap, hangerig (N10 en klacht 10); duzelig (N17 en klacht 13), "mopperig' (N1 en klacht 11), terwijl N item 7 'wordt U weleens door zorgen uit de slaap gehouden" een combinttie is wan klacht 8 (piekeren) en 12 (slapeloos). Als men bovendien bedenkt dat de variabelen additief gescored zijn en resp. uit 14 (neuroticisme, waarvan $7 \mathrm{~N}$ en $7 \mathrm{NS}$ ); 9 (lichamelijke klachten) en 4 (psychische klachten) items bestaan - dan is een positieve samenhang niet verwonderlijk.

21. Argumenten voor deze stelling vindt men in mij bespreking van Ormel's proefschift in Gezondheid en Samenleving, 2, 1981, 173-75.

22. Op pagina 77 van zijn proefschrift (Aakster 1972) noemt de auteur zijn bronnen: hij selecteert 134 items (alle items die teminste 2 matl woorkomen) - legt ze aan 4 Nederlandse sociaal geneeskundigen voor en stelt "with their help the number of items could be considerably reduced".

*) 23. Cassee trok 350 personen; er waren 300 bruikbare interviews, warwwege de lengtte der vragenlijst is de ene helft van de lijst aan de ene helft van de respondenten voorgelegd en 
de ander helft an de andere.

De cortelaties met de VOEG hebben betrekking op 145 personen.

24. Aakster gebruikt in zijn analyse alleen de amtwoorden wan personen, die tol hun 20 ste levensjaar een wolledig ouderlijk gezin hebben gehad.

25. Aakster presenteert 11 onafhankelijke variabelen: leeftijd, geslacht, aantal kinderen, uren slaap, melkconsumptie, lichamelike activiteit, sociale mobiliteit, desintegratie ouderlijk gezin, ontevredenheid woonplaats, affectieve dissatisfactie, status dissatisfactie, piekeren. Voor deze elf geeft hij ook de 1 le orde partiele correlaties. Deze zijn (met de Algemene Klachten index) geslacht $(.110)$, uren slaap $(-.088)$, lichamelijke actiwiteit $(129)$, desintegratie ouderlijk gezin $(-115)$, ontevredenheid woonplaats $(.064)$, affectieve dissatisfactie $(.143)$, status dissatisfactie $(-.086)$, piekeren $(.338)$.

26. De door Arrindell gegeven resultaten zijn miet exact te traceren. Het tijdstip van onderzoek is niet vermeld; noch de aard wan de geselecteerde populatie. Wat betreft de vermelde correlaties is niet duidelijk op welke wan de drie steekproeven (2 groepen "normalen" en een groep "fobische lijders") ze betrekking hebben. De resultaten kunnen dan ook slechts met voorzichtigheid worden gehanteerd.

27. In de publicatie "satisfactie en leefsituatie" waaruit de vermelde correlatiecoëfficiênten afkomstig zijn - wordt wel gebruik gemaakt wan multivariate (meestal factoranalytische) technieken; deze zijn echter toegespitst op het verklaren van de verschillende satislactiescores, zodat de resultaten niet bruikbaar zijn voor ons doel.

28. De door de equipe wan Nuyens gebruikte analysemethode makt de interpretatie van de resultaten niet eenvoudig. De resultaten worden gepresenteerd in een groot aantal meer-dimensionele kruistabellen, waarin de gemiddelde waarde van de afhankelijke variabele wordt weergegeven onder een aantal variërende condities. Het gaat hier om grote aantallen tabellen (voor 'huisarts- en specialistconsumptie" zijn het er 189; de geneesmiddelenconsumptie: 159; en ook over onderwerp 'klachten' presenteert men toch nog altijd 60 tabellen). Aangezien de specifieke samenstelling van de condities per tabel gegeven is en in het algemeen de ziektegeschiedenis van de respondent en het al dan niet chronisch ziek zijn tot de waste condities behoren is alleen een effect dat voor alle categorieën geldt zinvol te interpreteren.

29. Volgens de auteurs zijn bepaalde categorieën in de steekproef ("persons experiencing episodes of illness, rural Southern blacks and Spanish heritage persons living in the Southwest') oververtegemwoordigd. Om toch schattingen voor de totale bevolking van de USA te kumnen maken is een gewogen antal gebruikt. Onzes inziens is dit een merkwaardige techniek, dje er op neerkomt dat bepaalde records gewoon gedupliceerd wor den. Beter ware het de 'oversampling' terug te brengen tot een representatief deell wan het onderzoek wararin men pure bevolkingsanalyses wil verrichten. (Zie bijwoorbeeld Or. mel's techniek. Ormel, 1980 , hifdst. IV, 74 e.v.).

30. In het model van Andersen en Aday zijn ook opgenomen de variabelen: "vaste dokter", "verzekering", aantal artsen per 1000 inwoners". De artsendichtheid heeft geen inwloed. De beide andere variabelen zijn niet relevant woor de Nederlandse gezondheidszorg met een varn de Verenigde Staten sterk verschillend verzekeringssysteem.

*) De noten 23-30 hebben betrekking op het in Bijlage A toegevoegde schema met de resultaten van de besproken onderzoekingen. 
31. In Nijhofs correlatiematrix $(282-283)$ vindt men het volgende blokje correlaties

\begin{tabular}{|c|c|c|c|c|c|c|c|c|c|}
\hline & & \multirow{2}{*}{$\begin{array}{r}\text { WOEG } \\
5\end{array}$} & \multicolumn{2}{|c|}{ DV ZUNG } & \multicolumn{2}{|c|}{ ABV-NSLANGNER } & \multirow{2}{*}{$\begin{array}{r}\text { EYSENCK } \\
10\end{array}$} & \multirow{2}{*}{$\begin{array}{r}\text { MMPU-SC } \\
\text { i1... }\end{array}$} & \multirow{2}{*}{$\begin{array}{r}\text { SL. } \\
\text { Gezh } \\
18\end{array}$} \\
\hline & & & 6 & 7 & 8 & 9 & & & \\
\hline Beroepsstatus & 1 & -08 & -04 & -08 & -10 & -07 & .07 & -05. & -12 \\
\hline $\begin{array}{l}\text { niveau } \\
\text { Opleidings- }\end{array}$ & 2 & -16 & -05 & 08 & -13 & -12 & -09 & -06. & .25 \\
\hline duntur & 3 & -12 & -105 & 07 & -12 & -10 & -07 & -06 & .20 \\
\hline Inkomen & 4 & -15 & .09 & -03 & -20 & -16 & -13 & -09. & -18 \\
\hline & & $\cdot$ & . & $\cdot$ & " & • & - & $\cdots$ & 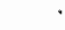 \\
\hline & & $\cdot$ & * & · & $\cdot$ & . & - & $\cdots$ & " \\
\hline Slechte & & " & v & $\cdot$ & $\cdot$ & . & . & $\cdots$ & $\circ$ \\
\hline gezondh. & 18 & 43 & 23 & -02 & 39 & 36 & 17 & 14. & $\mathrm{x}$ \\
\hline
\end{tabular}

Houdt men rekening met 'gezondheidstoestand' (var. 18) dan dallen de (partiêle) correlathes in de eerste kolom (relatie soc, ec. status/VOEG) tot respectievellijk -.03 (beroepsstatus), -.06 (opleidingsniveau); .04 (opleidingsduur) en .08 (inkomen). Men moet hier"bij weer wel beseffen dat de variabelle 'slechte gezondheid' de subjectieve mening van de ondervraagde weergeeft. De gevonden tamelijk hoge correlaties met VOEG en ABV. NS, kunnen ook opgevat worden als verbanden tussen met elkaar vewante begrippen.

32. Men kan in het Leef Situatie Onderzoek 1977 de aanduiding "langdurig ziek" krijgen (zie het uitgewerkte codeboek LSO 77. Central Bureau voor de Statistiek z.j. z.a.) als men

le $\mathrm{Op} 1$ van de 26 genoemde aanduidingen (1. astma, chronische bronchitis $/ 2$. TBC $/ 3$. neus bijholte ontskeking /4. hartafwijking /5. hoge bloeddruk $/ 6$. be roerte en gevolgen wan een beroerte 17 . spataderen /8. aambeien 19. maagzweer of zweer 12-vingerige darm /10. andere mangklachten 11 . dikke darmstoornissen, diaree of andere buikklachter /12. galstenen of andere galblaas- en leverziekten /13. breuk/14. nierstenen $/ 15$. chronische blaasontsteking/16. voor de man: prostaatklachten /17. voor de vrouw: verzakking / 18 . suikerziekte $/ 19$. schildklierafwijking $/ 20$. rugaandoening van hardnekkige aard, hernia/21. rheumatische gewrichtspijnen met koorts, slijtage van gewrichten, gewrichtsrheuma $/ 22$. epilepsie of andere toevallen $/ 23$. migraine of ernstige hoofdpijnen $/ 24$, chronische huidaandoening, exceem $/ 25$, ge zwelvorming of kanker $/ 26$. errstige gevolgen wan en ongeval, (zoals breuken, ernstige brandwonden), eénmal of vaker code 2 (enkele keer en langer dan 3 maanden) 4-6 (vaker) of 8 (onbekend hoe vaak - langer dan 3 maanden) scoort.

$2 \mathrm{e}$ hetzij doof/of slechthorend is of stottert (a) en op bovengenoemde aandoeningen "korter dan 3 maanden" of "een enkele keer en onbekend hoe lang'scoort (b) en nog een andere langdurige aandoening noemt (c),

$3 \mathrm{e}$ de in de vorige regel onder a en $\mathrm{c}$ genoende combinatic vertoont;

$4 \mathrm{e}$ op de 26 andoeningen onbekend of onbekend lang scoort, maar wel doof of slachtziend is of stottert én een andere langdurige aandoening noent. 
Het punt zit hem niet zozeer in de ingewiklkeldhelid wan de combinaties, mas in de arard van de 26 aundoeningen en de drie zicht- w hoorbare gebreken. Beziet men de gecursiverde ziekten dan behoren die toch eerder bij de (lichte) ongemakken des levens dan bij de het fumctioneren hinderemde of het leven bedreigende alandoeningen. Voor ons eigen doel is de door het CBS samengestelde maat niet bruikbaar. Wij zullen zelf een andere combiruatie maken.

33. Het doetter in dit verband nier toe welke deze variabelen zijn; Mechanic probeerde de klachterascores te verklaren wan (jonge) volwassenen die hij 16 jaar daarvoor als kind had onderwatad. De variabelen die in zijn modell de twee basisvariabelen "gezondheidstoestand" en "neuroticisme" beinvloeden zijn zeer specifiek voor die probleemstelling.

34. Van Poppel (1978) maakt gebruik van Engelse, Franse en Noorse en Australische onderzoeksgegevens. In hei algemeen geidt dat voor mannen de sociale verschilien un sterftecifers her grootste zijn (de enige uitzondering op de hoog/laag dimensie vormen personen werkzaam in de landbouw), maar ook voor wrouwen (geclassificeerd naar de status wan het beroep van hun man) zijn verschillen aantoonbaar. De grootste verschillen vindt men vóor het $40 \mathrm{e}-45 \mathrm{e}$ levensjaar.

35. Er is een zekere wisselwerking te onderkennen. Een slechte gezondheidstoestand van jongsafaan kan iemand sterk belemmeren bij het beklimmen van de maatschappelijke ladder. Ook een op latere leeftijd (plotseling) afnemend fysiek vermogen kan (bij ontslag of arbeidsongeschiktheid) iemands maatschappelijke status coen dalen.

In het werk van Harold Luft (1978) staat deze laatste benadering van de relatie tussen gezondheid en economische status centraal. Zijn 'disability rates' vertonen grote gelijkenis met de in \$ 6.5.1. gepresenteerde grafieken (zij het dat hij zich tot incidentiestatistieken beperkt en wij prevalentie-maten gebruiken).

36. Een (zij het zijdelings) argument woor het bestaan wan een factor "klaaggeneigdheid' kan op een indirecte manier worden ontleend aan de gegevens die Ormel (1980b) vermeldt over de respons van de personen die hij na zes jaren opnieuw benaderd heeft. Van de toevalssteekproef uit Jessen's bestand $(n=232$ ) respondeerden uiteindelijk 181 personen $(61 \%)$. Van de aanvulling van zijn steekproef met personen die in 1970 hoog op de neuroticismelijst scoorden $(n=131$ ) respondeerde maar liefst $89 \%$ (Ormel $1980 \mathrm{~b}, 75$, e.w.)

37. Het feit dat Cassee als enige geen verband tussen geslacht en klachtenscore vindt had hem ernstig moeten doen twijfelen aan de juistheid van de samenstelling van de steekproet.

38. Onder behandelde vormen van geestelijk onwelbevinden wordt verstaan: "opname in een psychiatrische inrichting", "ambulante psychotherapeutische behandeling', maar ook bijvoorbeeld door huisartsen opgegeven aanuallen patienten-met-psychosociale-problematiek. Onbehandelde patiënten zijn personen die hoog scoren op lijsten met symptomen, die geacht worden geestelijke gezondheid te meten.

39. Drop hatr index "vluchtgedrag" bevat als belangrijkste componenten: echtscheidingscijfiers, (e)migratic, niet uitgebrachte stemmen, en negatieve factorladingen voor "index aggressieve misdrijven' en "verkeersongevallen".

40. Er zijn twe versies van dit bestand in onloop. Eén bestand bevat een CBS-code voor de woongemeente van de respondent. Het andere bestand bevat een uitvoerige classificatic van het beroep van de ondervraagde.

Uit oogpunt van bescherming van de persoonlijke levenssfeer van de ondervraggde personen worden geen bestanden werstrekt met belde gegevens in combinatic. Het N.H.I. 
beschikt over het bestand met gemeentecode. Onze analyses zujn uitgevoerd met $\mathrm{n}=4157$.

41. Eigenlijk zi jn het 4159 ingevulde vragenlijsten; bij controle bleken $2 \times 2$ identieke records in het bestand aanwezig.

42. Voor degenen met ambitiesgegevens uit dit onderzaek te "bestellen" is het wellicht van belang te weten dat de woonplaats van de respondent niet is gecodeerd.

43. Als regel was minder dan 1 procent van de antwoorden als onbekend gecodeerd. Uitzonderingen waren de vragen over het gezinsinkomen waarop meer dan $5 \%$ wan de irespondenten geen antwoord wilde geven. Op de gevolgde procedure: het toekennen wan het groepsgemiddelde aan de ontbrekende wasten, is kritiek mogelijk. Het is echter in de gebruikte standaardprogrammatuur (het SPSS-pakket) de enige mogelijkheid (naast weglateny om het aantal gevallen niet al te drastisct terug te laten lopen.

44. De formulering van het $\mathrm{CBS}$ is hier exact aangehouden.

45. We hebben de (niet ongebruikelijke) procedure toegepast om de ontbrekende warde (als het er niet te veet waren: de grens is gelegd bij 5 of meer) als 'klacht' te beschouwen. Immers, men heeft geaarzeld bij het invullen, hetgeen men kan interpreteren als wel eens", maar niet precies volgens de formulering van de vraag. Aan de 10 gevallen warin men meer dan 4 onderdelen riet had ingevuld is het groepsgemiddelde toegekend in de regressie-analyses.

46. Volgens de regel dat het aantal gepredetermineerde variabelen buiten die vergelijkingen groter of gelijk moet zijn aan het aantal afhankelijke variabelen in de vergellijking minus een.

47. Volgens de formule (significantie van thet verschil tussen de coëfficiönten van twee dummy-variabelen): als $Z=x_{i j}-x_{j}$ dan is var $(z)=\operatorname{var}\left(x_{i}\right)+\operatorname{var}\left(x_{j}\right)-2 \operatorname{cow}\left(x_{i}, x_{j}\right)$. $T$ is dan

$$
\frac{z}{\operatorname{Vvar}(z)}
$$

\section{Noten deel II Doktersbezoek}

1. De oudere literatuur kent dit onderscheid niet, noch in empirische zin, noch in theoretische. In het (overigens voortreffelijke en uitgebreide) uit 1976 daterende literaturoverzicht van Kuyvenhoven en Touw komt het onderscheid niet woor, noch in de kritische beschouwing van McKinlay (1972).

2. De studies van Van der Gaag (1978), Rutten (1978) beperken zich tot resp. 4 en 3 artsen uit het gezondheidscentrum Ommoord, Rotterdam. Olienans en Van de Ven (1975) beschrijven én huisartspraktijk. Stoddard en Bearer (1981) beperken zich ook tot één universitaire praktijk met enkele artsen in dienstverband. Tessler, Mechanic en Dimond (1976) beschrijven én groepspraktijk evenals Kuyvenhoven en Touw (1978).

3. Vergelijk ook onze in hfst. 3 van deel I geformulecrde kritiek op de bruikbarheid wari bevolkingsstudies voor een analyse wan de wragg naar diensten van de huisarts.

4. Wij onderscheiden geen aparte ategorie "mogelijkheidswariabelen maar brengen deze onder bij "vraag en aanbod". De bereikbaarheid van de praktijk bijvoorbeeld is een 
typische alanbodfactor. Variabelen die op verzekering tegen inkomstenderving en ziektekosten betrekking hebben worden als vraagfactoren beschouwd.

5. We hebben al eenswat schamper gedaan (zie noot 7 deel 1 ) over het grote belang dat in sociologenkringen aan het 'Lay referral system' wordt gehecht. Onze gramschap werd eerder gewekt door de onnodige, vanuit een medisch oogpunt geformuleerde, introductie van de term "leken" dan door de gedachte dat mensen bun omgeving raadplegen als ze andere dan routine-beslissingen moeten nemen. Het tweede gedeelte van Mootz hatar proefschrift (1981) levert duidelijke aanwijzingen voor thet nut van een zienswijze die rekening houdt met de invloed van de directe sociale omgeving van de zieken.

6. Er zijn nogal wat verschillen en zelfs tegensirijdigheden te constateren tussen beide vrijwel gehjktjdig gepubliceerde artikelen. In vergelijking met het eerste tamelijk eenvoudige regressiemodel lijkt het tweede getroffen door een soort wervelstorm. De anwezigheid van de tweede auteur zal hier net vreemd aan zijn geweest.

7. Het model van Wolfe en Van der Gaag is niet het enige econometrische model warin gezondheidstoestand rommelig, heterogeen en in zekere zin tautologisch wordt getormuleerd. Ook het veelgeprezen werk van Grossman, veelgeprezen omdat bijna elke econoom aan zijn "human capital' benadering (mensen investeren in gezondheid als basis voor hun inkomen) in positieve zin refereert, bevat zo'n allegartje van indicatoren. In Grossman en Benham (1974) wordt slechte gezondheid gedefinieerd als volgt: "Two measures of self evaluation of health status are included in the data: (1) the number of symptoms, and (2) individuals' self evaluation of their general health as excellent, good, fair or poor". (Grossman en Benham, 1974, 208).

Dit zijn typische VOEG-achtige-subjectieve maten, die slechts ten dele met iemands gezondheidstoest and te maken hebben. De auteurs vinden een stevige multicollineairiteüt. tussen "schooling" en deze index (Grossman en Benham, 224). Aangezien ze alleen (blanke) mannen tussen de 18 en 64 jaar in hun onderzoek nat de verhouding tussen gezondheid, inkomen en arbeidstijd betrekken, walt de schade nog wel mee; met gezondheid heeft hun analyse echter weinig te maken.

8. Het verdient overigens in het beeld van onze "jacht op de groene weduwe' ananbeveling om Kooy's model wan huwelijksgeluk om te draaien en zijn maan woor 'geestelijke gezondheid' niet als onafhankelijke, maar als afhankelijke variabele te gebruiken met als verklarende factoren de mate van huwelijksgeluk en tevredenheid.

9. Tot 1 januari 1981 althans, daarna is dit extra percentage gehalveerd (zie v.d. Ven, 1981 * 52).

10. Het moet ons wan het hart, dat we met enige afgunst zien welk een fascinerend onderzoeksbestanden in de Verenigde Staten bestam. Het artikel van Wilensky en Rossiter is gebaseerd op gegevens wit de National Medical Care Expenditure Survey.

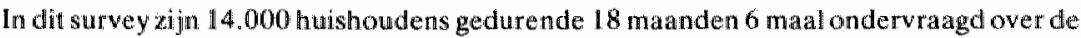
contacten die men in deze periode met de gezondheidszorg had, om welke reden men contact heeft gezochi, wie het initiatief nam, wat men ervoor uitgaf etc.

Uit alle in het onderzoek genoemde dokters en overige leveranciers van gezondheidszorg is een steekproef wan $25 \%$ getrokken, van welke steekproef aanvullende informatie is verkregen. Naast dit uitgavenonderzoek bestan ook nog de bekende Health Interview Surveys on Health Examination Surveys, warbij in laatstgenoemd onderzock geprobeerd is iemands gezondheidstoestand d.m.v. Fysieke en biometrische criteria vast te leggen. Er zin blijkbar ook volkstellingsgegevens categoraal beschikbaar. Sloan (1974) 
baseert xijn uitgebreide studie ower 'Physicians hours of work decisions" op de census 1960 (the Public Use $1 \%$ sample), waar vrijwel $100 \%$ van de onderwraggde artsen de meest untgebreide gegevens over inkomens, productie, werkwijze etc. opgaf:

Waar in Nederland verschillende professies (en met name de medische) succeswol hebben kumnen profiteren van de golf van ongerustheid die er ontstaan is ower de mate waarin automatisering de persoonlijke levenssfeer zou kwnen aantasten (met name door introm ductie van het dubieuze begrip "groepsprivacy" (Roelink, 1981,) waarin men mu zells hell praktijkadres van een huisarts als een privacy-gevoelig gegeven zou willen beschouwen), doet deze Amerikaanse werkwijze de wragg rijzen of de Nederlandse bezorgdheid niet wat te ver is doorgevoerd en zo de mogelijkheden tot wetenschappelijk onderzoek beperkt.

11. We hebben hier nog maar niet gesproken over de door Van de Ven genoende 'particulierachtige' ziekenkostenregeling voor ambtenaren en de mogelijke inviloed van de hoogte van fiscale aftrekposten op het gedrag van de meer bemiddelde consument zo tegen het einde van het fiscale jaar.

12. Heel puristisch gesproken heeft men het dan nog niet precies uitgezocht; omdat mogelijke transwersale, inderdaad aan de wijze van verzekering toe te schrijven verschillen nog niet identiek zijn met veranderingen in het werzekeringssysteem en dat omgekeerd het effect van verandering (zeker wan een al langer bestaand systeem) niet zonder meer uit elders aangetroffen transwersale verschillen kan worden afgeleid. Berekeningen als die van Petersen (1982) llaten zien van hoeveel 'ombekenden' het vaststellen van een effect van een volledige volkswerzekering al dan niet gecombineerd met een eigen bijdrage afhankelijk is.

13. Als inderdaad de verzuimfrequentie afneemt en de verzuimduur toeneemt bij een systeem van 'wachtdagen', zal het effect op de vraag naar huisartsenhulp juist positief zijo, Voor kortdurend verzuim wordt de huisarts zelden geraiadpleegd; voor langer durend verzuim wel.

14. Het is de vraag of de door Parkin gevonden parameters conditioneel zijn. Men kan zich voorstellen, dat afstand opgevat wordt in verhouding tot de afstand die men in het algemeen moet afleggen om een goed te verkrijgen. In dunbevolkte gebieden zullen de categorieên groter zijn. Parkïn vond ook dat consulten van patiẻnten uit de hoogste twee sociale strata miet door de afstand werden beïnvloed; evenals die van (meestal buitenshuis werkzame) mannen van 15-64 jaar. Voor de laatste groep is de ligging van de praktijk ten opzichte van de route huis/werk waarschijnlijk van groter belaing. Het zou de moeite waard zijn om in Nederland de invloed van een concentratie van zorgverleners (zoals in een gezondheidscentrum of groepspraktijk) en de daamee toenemende gemiddelde afstandi vast te stellen op het gebruik.

15. Aangezien een belangrijk deel van de uitbreiding van het huisartsenbestand door middel van associatie plaatsvindt, neemt het aantal praktijkadressen veel minder snel toe dan het aantal artsen. Zo geldt voor 1981 dat van de 348 nieuwe zelfstandige westigingen er 170 $(48.6 \%)$ als "verdunning' zijn te beschouwen. Deze 170 extra huisartsen leveren echter niet meer dan 60 nieuwe praktijkadressen op (NHI-Cijfers uit de Huisartsenregistratie, Vestigingen 3,24 en 26).

16. In systemen wan gezondheidszorg gebaseerd op honorering per verrichting is productiviteit wan groeps- en solopraktijken dikwijls onderwerp van studie geweest (Lorant \& Kimbell, 1976). 
In Nederland houdt Heesters (1980a en b, 1981 b) zich bezig met de wijze warop de Nederlandse huisarts zijn inkomen verdient. Heesters moet zich (noodgedwongen) dakwijls beperken tot schattingen en extrapolaties van scharse gegevens.

17. Om de lezer een indruk te geven wan de complexteil (die in onze ogen wel heel erg empericistisch an ad hoc andoet), volgt hier een overzicht van de variabelen die in Sloan's model het inkomen (per uur of per week) bepalen = geslach (sterk negatief vrouwelijke artsen verdienen veel minder (1960!) dan mannen); leefrid (kromlinig - de hoogsile werdiensten tussen $40-44$ jaar), herkomst (afkomstig wit Engelssprekend of uit niel-Engels-taalgebied - latste werkt negatief) ras (zwarte dokters verdienen minder); partimelfull-time, in dienst vam prive-onderneming of owerheid vs vily beroep (hoogste verdienste als vrij beroep, dan privé-ondeneming, dan overheid), bijuerdiense naast eigen prakink (verdienen meer), dan 3 dummies als de arts 5 jar geleder in andere gemeente, andere staat of ander land praktizeerde (verdienen minder - minste uit ander land); gemiddeld wkomen vd poputatie (gen effect); \% personen $<5$ en $>65$ (geen effect); a anal arben per inwoners (sterk effect; naarmate er minder artsen per inwoners zijn, zijn de verdiensten hoger); wee verzekeringswariabelen (geen sign. effect-gegevens uit 1960 vór Medicare en Medicaid) en een wariabele voor het antal ziektedagen van de bevolking (pos. effect op inkomen).

De met behulp van deze vergelijking geschatte inkomensvariabelen worden in verschillende varianten (in een twee-stadia-schatting, met en zonder een kwadratische inkomensterm) met een aantal extra variabelen (gezinsituatie, overige gezinsinkomen, gemiddield inkomen wan de artsen in de statt als referentie-inkomen) gebruikt om het aantal gewerkte uren per week en het aantal gewerkte weken per jaar te verklaren. (Sloan 1974,313 en 316,317 ).

18. Twee variabelen hebben we weggelaten - er is een negatief verband ussen tijd die men bij de dokter kwijt is (wachttijd èn behandeltijd) en de kans op terugbestellen. (Het maakt o.f. nogal wat uit om welk van beide componenten het gaat). Een positief verband vinden de auteurs met de tijd die het kost om een afspraak te maken met de arts. Ook hier zujn meerdere interpretaties mogelijk.

19. Voor het waststellen van de afstand zijn wij dank verschuldigd aan Mr. Norman Chaplain - medewerker aan het Institute of Health Service Administrators in Londen.

20. In de officiele publicatie (OPCS, 1974) wordt gesproken ower 53 praktijken. Dit komt omdat in 2 gevallen alle 3 lespectievelijk 6 huisartsen uit een bepaalde plaats aan het onderzoek meededen. Aangezien het hier om formed niet gerelateerde solopraktijken ging, hebben we ze in onze analyse well afzonderlijk meegeteld.

21. Het aantal ingeschreven patienten is gewogen voor de periode dat ze in het teljar zijn ingeschreven.

22. Merkwardigerwijze zijn dergelijke gegevens, die men in Nederland zo uit de publicaties van het National Ziekenhuis Instituut en de Geneeskunde Hoofd Inspectie kan halen, in Engeland niet centraal gepubliceerd. Weliswaar geeft het 'Institute of Health Service Administrators' jaarlijks thet 'Hospitals \& Health Services Year Book' uit, waarin bet antal acute beds" per zickenhuis staat vermeld, maar de voor toerekening van ziekenhuisbedden zo belangrijke rayonindeling (natar herkomst van de patiënten) ontbreekt. In het "Year Book" staan zelfs geen bevolkingsantallen, evenmin als gegevens over het aantal specialister.

Voor het overige is informatie verkrijgbar bij de 15 Regional Health Authorities (14 in 
Engeland en 1 in Wales). Het probleem hierbij is dat we in feite gegevens nodig hebben per "hospital managememt committee" een regio-indeling op hoger niveau, die bij de reorganisatie (1974) wan de National Health Service opgeheven is. De gegevens voor de regio's moeten ergens in de archieven van het Department of Health and Social Security liggen.

23. Een overzicht van in Nederlandse praktijk-studies gevonden contactrequenties geven Verhoeff (1979) en Heesters (1980).

24. Vian Es en Pijlman noemen getallen voor de 'oogverwijzingen" en de "vervolgverwijzingen' van 25 respectievelijk $33 \%$. Binnen deze vervolgverwijzingen bestatat echter weer 1/3 uit verwijzingen naar de oogarts. Het totaal aantal vervolgverwijzingen minus verwijzingen naar de oogarts bedraagt dus ongeveer $22 \%$.

25. Berekening. Gemiddeld verwijscijfer $1970 / 1971$ voor ZF-verzekerden 450 per 1000 verz:; gewogen voor een $\pm 1 / 6$ deel lager liggend verwijscijfer voor particulieren is dit. 70 $\times 450+.30 \times(5 / 6 \times 450)=427.5$. Hiervan trekken we de $25+22 \%$ oog- en verwolgverwijzingen af. Resteert 227 verwijzingen per 1000 patienten.

26. In feite kan men natuurlijk alleen de voorspellingen toetsen als men indicatoren heeft voor de tijdprijs van mensen. Inkomen of mate warin men thuis of op het werk gemist kan worden zijn hier van belang; dergelijke gegevens zijn echter niet in het NMS opgenomen.

27. In een variantie-analyse waar de verschillen tussen samenwerkende en solistische huisartsen zijn geanalyseerd met "prakijkgroote" als cowariaat, vinden we dezelfde resultaten.

28. Ondanks de overeenkomst in opzet en het gebrwik van hetzelfde materiaal zijn onze resultaten toch niet goed met die van Van Vliet en Van de Ven te vergelijken. Ten eerste niet ondat zij grote groepen ondervraagden buiten de analyse laten (hun analyses hebben betrekking op personen van 18 jaar in plats van 15 jaar en ouder; en bovendien lijkt het erop alsof iedereen met een ontbrekende waarde uit het bestand is gelaten), ten tweede niet omdat zij allerlei tevredenheidsmaten en het algemene oordeel van de respondent over zijn gezondheid als verklarende variabele hebben opgenomen.

29. Wat betreft de variabelen 'huisarts-ja/nee" en "aantal contacten met huisarts" is alleen aan ontbrekende waarden 'geknutseld'. Zo is aangenomen dat de code ( 0 ) bij de wraag: "huisarts" nee (1) of ja (2), bedoeld is als 1. Was ingevuld "onbekend' (3) dan is daarwan gemaakt "meen" (1) als in de volgende mat het aantal contacten 0 bedroeg of "miet ingevuld' en 'ja' als wel een frequentie werd genoemd.

Was de frequewice onbekend, dan is deze op nul gesteld als de vorige vraag met nee werd beantwoord en op " 1 " gesteld als men positief had geantwoord op de vratag of er contact met de huisarts was geweest.

Was er sprake van een discrepantie tussen huisarts ja/nee en frequentie dan hebben we aan de "frequentie" meer warde gehecht dan aan het invullen van de eerstgenoemde vrarg.

30. In het LSO zijn 4 categorieën onderscheiden:

niet verzekerd of onbekend

$1.5 \%$

ziekentonds verplicht

ziekenfonds wrijwillig

particulier verzekerd

$54.8 \%$

$17.4 \%$

$26.3 \%$

$n=4157$

31. Bij de berekening is gebruik gemaakt van gegevens uit de huistrtsenregistratie wan het 
NHI. Daarin zijn opgenomen zelfstandig gevestigde huisartsen (huisartsen met en medewerkerscontract met de ziekenfondsen) en als assistent werkzame huisartsen: huisartsen die voor een perilode langer dan 6 maanden in loondienst zijn wan aen andere huisarts of met hem een wamemerscontract hebben. Als peildatum is 1 juli 1977 aangehouden.

32. Ook het berekenen wan de afstand-tot-het-ziekenhuis is minder simpel dan het lijkt; in een groot aantal gewallen moeten (min of meer arbitraire) beslissingen worden genomen. Zo is bij gemeentem die voor minder dan $50 \%$ op eén andere gemeente zijn georiènteerd de gemidelde afstand van de twee of drie orientatiegemeenten genomen. Bijgemeenten met meer woonkernen zijn we uitgegaan van de hoofdwoonkern. Was deze qua inwonertal niet goed te onderkennen, dan is de plaats genomen waar het gemeentehuis was gevestigd. Wat we met Ambt-Delden hebben gedaan (een gemeente zonder woonkernen, als een cirkel gelegen rond een andere gemeente: Stad Delden. waar ook het gemeentehuis van Ambi-Delden is gevestigd) weet ik eerlijk niet meer. Gemeenten waar vanwege het ontbreken van een weg de afstand-over-de-weg niet kon worden gemeten (eilanden) is een warde toegekend die ansluit op de resi wan de verdeling.

33. Het "recept" voor thet berekenen wan het alantal beschikbare ziekenhuisbedden voor gemeenten zonder algemeen ziekenhuis luidt als volgt:

1. Men neme de (all genoemde) Adorp-lijst van de GHI woor jaar j

2. Men zoeke de orièntatie op van alle gemeenten op alle gemeenten-met-ziekenhuis

3. Men stelle een percentage vast, beneden welk men de oriêntatie niet meer meetelt in ons gewal $10 \%$. Dit betekent dat alle orientaties $<10 \%$ verwaarloosd worden

4. Het overgebleven orientatiepercentage (de som van alle orièntaties $>10 \%$ ) stelle men op 100

5. Men berekene opnieuw de "opgerekte' orientatiepercentages

6. Men dele natrato van deze percentages de inwoners van de gemeente toe aan de gemeenten-met-ziekenhuis waarop ze zijn georiënteerd

7. Men sommere per ziekenthuisgemeente de berekende inwonersaantalten; deze som noemen we het rayon

8. Na de bedden nog. Wij hebben genomen het aantal in de NZL/GHLCBS enquète opgegeven antal bedden exchsief de wikgen voor gezonde zuigelingen in alle adgemene en Academische Ziekentuizen in een gemeente tezamen.

9. Men dele het aantal bedden $x 1000$ door het aantal imwoners van het rayon. Wij hebben nu het antal bedden per 1000 inwoners in het rayon.

10. Din latste stap is het antal bedden per gemeente. Dit is voor de (opgerekte) orientatie gewogen som van de bedden uit de rayons van de gemeenten-met-ziekenhuis waarop de gemeenten-zonder-zhekenhuis zijn georiènteerd.

34. Uit de door het NZL verzamelde specialistengegevens zijin geselecteerd de specialisten jonger dan 70 jaar. Het interessante van deze NZ1-gegevens is, dat de verdeling van specialisten over instellingen uitgedrukt in dagdelen is geregistreerd. Per instelling is ook de gomentecode bekend. Wij hebben per gemeente-met-ziekenhuis deze dagdelen opgeteld; liet gemiddeld antal dagdelen toegekend in de gevallen dat dit niet is opgegeven (wooral bij specialisten-in-dienstverband; bijworbeeld in academische ziekenhuizen (en voor de spechalisten praktizerend in gemeenten zonder algemeen of academisch ziek enhuis de dagdelen nar rato van de orientatiepercentages van deze gemeenten toegedeeld aan de rayons wartoe de betreffende gemeente behoort. 
Wij hebben elf groepen onderscheiden (Basis-interne, Deelspechalismen, Basis-chirurgie: Deelspecialismen chirurgie, KNO, Oogheelkunde, Dermatologie, Gyneacologie-verloskunde, Netrologie-Psychiatrie en Zenuw-Zielsziekten, ondersteunende specialismen (Radiologie. Anesthesie etc.) overige specialismen (Allergologie, Revalidatie)). In deze analyses gebruiken we alleen het totaalcijfer. Bij constructie van een model voor de gezondheidszorg worden ook de verschillende groepen gebruikt. 


\section{Literatuurlijst}

AAKSTER, C. Socio-cultural variables in the etiology of health disturbances, a sociological approach, Diss. Groningen, 1972.

ACTON, J. P. Non-monetary factors in the demand for medical services: some empirical evidence. Journal of Political Economy, 83, 1975, 595-614.

ADRIAANSE, H. M. J. DROP, R. HALFERS en H. PHILIPSEN. 'Leeft Nederland Oké?", R. U. Limburg, Maastricht, 1981.

AKKERMAN, A. E. Persoonlijkheidstests als basis voor een persoonlijkheidsindruk, Ned. Tijdschrift voor de Psychologie, 35, 1980, 203-214.

ANDERSEN, R A behavioral model of families use of health services, Research Series 25 , Chicago, Center for Health Administration Studies, 1968.

AMDERSEN, R., J. KRAVTTS en O. W. ANDERSON. Equity in health services, empirical analysis in sociall policy, Ballinger Publ. Co., Cambridge, USA, 1975.

ANDERSEN, R., A. FRANCIS, J. LION en V. S. DAUGHETY. Psychologically related illness and health services utilization, Medical Care, $\mathbb{1} 5,1977,59-73$.

ANDERSEN, R en L. A. ADAY. Access to medical care in the U.S., realized and potential, Medical Care, $16,1978,533 m 546$.

ANDERSON, 1. G. Health services utilization: framework and review, Health Services Research. $8,1973,184-199$.

APPELS, A. Screenen als methode voor preventie in de geestelijke gezondheidszorg, Swets en Zeitlinger, Arnsterdam, 1975. (proefschrift).

ARRINDELL. W. A., S. A. DAMSMA en H. ETTEMA. De score op de Delftse Vragenlijst (DV) als neuroticisme-index in epidemiologisch onderzoek, Tijdschrift voor Sociale Geneeskunde, $58,1980,599-603$.

BECK, R. G. enI. M. HORNE. Utilization of publicly insured health services in Saskatchewan before, during and after copayment, Medical Care, 18, 1980, 787-806.

BENSING, J. M. Aa P. M. VERHAAK. Konsultatieprojekt Eindhoven, Verwijspatronen, Utrecht, Nederlands Huisartsen Instituut, 1980.

BLALoCK. $H$. Causal inferences in non-experimental research. The Univ. of North Carolina Press, Chapel Hill, 1961. 
BLoos $\mathrm{Ch}$. Voeg-analyse in verband met chronische patièten, doctoraal scriptie, Sociologisch institumt van de Rijksuniversiteit te Leiden, 1971.

BREMER, G. J. en W. BROUWER. Ontwerp en toepassing van een huisartsen-anamneselijst, Huisarts en Wetenschap, 12, 1969, 321-322.

$B R E M E R, G$. J. Over het gebruik wan de huisartsen-anamneselijst bij vage, onduidelijke klach* ten, Huisarts en Wetenschap, 23, 1980, 53-58.

BUTLER, J. R. en MORGAN. Marital status and hospital use, British Journal of Preventive and Social Medicine, 31, 1977, 192-98,

CASSEE, E. Th. Naar de dokter, Boon, Meppel, 1973. (proefschrift).

CENTRAAL BUREAU voOR DE STATISTIEK. De leefsituatie van de Nederlandse bevolking, 1977.

deel 1. Kerncijfers, Staatsuitgeverij, 's-Gravenhage, 1978.

DIRKEN. J. M. Arbeid en stress, Wolters, Groningen, 1967. (proefschrift).

DOHRENWEND, B. P. B. S. DOHRENWEND. Sex differences in psychiatric disorders. Am. Journal of Sociology, 81, 1976, 1447-1452.

DOHRENWEND, B. P. en B. S. DOHRENWEND. Reply to Tudor and Gove's comment on 'Sex differences in psychiatric disorders", A m. Jourmal of Sociology, 82, 1977, 1336-1345.

DOPHEIDE, J. Verwijzingen door de huisarts; Enkele determinanten van het verwijscijfer van solo-huisartsen op het verstedelijkt platteland en forensengemeenten, Utrecht, Nederlands Huisartsen Instituut, 1982.

DROP, M. J. Kenmerken van gemeenten en verschillen in ziekte en afwijkend gedrag; resultaten eerste onderzoeksfase, Leiden, NIPG/TNO, 1971.

DROP, M. J. Arbeidsverdeling, normatieve integratie en typen van afwijkend gedrag, diss., Maastricht, 1979.

EUE, J. M. VON De wachtdagen in de ziektewet, Economisch Statistische Berichten, 1981. 3.42-45.

EinK, J. Th. M. VAN Levensgebeurtenissen en ziekte, Huisartsenpers, b. v, Utrecht, 1979. (proefschrift).

ES, J. C. VAN en H. R. PIILMAN Het verwijzen van ziekenfondspatiënten in 122 Nederlandse huisartspraktijken, Huisarts en Wetenschap, 13, 1970, 433-439.

EVANS, R. G. Supplier induced demand: some empirical evidence and implications, in M. Perlman, ed. The economics of health and medical care, The MacMillan Press, London and Basingstoke, 1974

EVANS, R. G. Bespreking van: The economics of health and medical care, The Canadian Journal of Economics, 9, 1976, 532-37.

FELDSTEIN. M. S. Econometric studies of thealth economics in M. D. Intrilligator \& D. A. Kendrick eds.: Frontiers of quantitatiwe economics, North Holland Publ. Cy, Amsterdam, 1974.

FLEMING, D. M. R. M. I. MAES. Facets of practice in the United Kingdom and Belgium, Allgemeinmedizin International, 9, 1980,5-11.

FOx. W. Gove's specific sex-role theory of mental illness: a research mote, Journal of Health and Social Behavior, 21, 1980, 260-267.

FUCHS, W. R. Who shall live?; Health, econornics and social choice, Basic Books, New York, 1974.

GAAG, J. VAN DER. An econometric anajysis of the Dutch healtin care system, dissertatie, Leiden, 1978.

GAAO, J. VAN DER en W. VAM DE WEN. The demand for primary health care, Medical Care, 10 , 
$1978,299-312$.

GADOUkEk, Riskante gewoonten en de zorg woor eigen welzijn, Wolters, Groningen, 1963. GADOUREK, 1. Absence and well-being of workers, Van Gorcum, Assen, 1965.

OOLDBERO. D. Phe detection of psychiatric illness by questionnaire, Oxford University Press, London, 1972.

GOVE, w. The relationship between sex roles, marital staltus and mental illiness, Social Forces, $51,1: 972,34-44$.

Gove, w Rex, marital status and mortality. American Journal of Sociology, 79, 1974, 45-67.

GOWE, W. R. E M. R. GEERKEN. The effect of children and employment of the mental health of married men and women, Social Forces, 56, 1977, 66-76.

GOVE, W. R. en A. F. TUDOR. Adult sex roles and mental illness, American Journal of Sociology, 78 , $1973,812-835$.

GOVE, W. R. en J F. TUDOR. Sex differences in mental illness, ent on Dohrenwend \& Dohrenwend, American Journal of Sociology, 82, 1977, 1327-1336.

OROENEWEGEN, P. en J. WAN DER ZEE. De Spreiding wan buisartsen over Nederland, deel II, huisarten en tandartsen wergeleken, Studie wit de Huisartsenregistratie, Utrecht, Nederlandse Huisartsen Instituut, 1982.

Grossman, M. L LENHAM. Health, hours and wages, in M. Periman ed., The economics of health and medical care, the Macmillan Press, Ltd., London en Basingstoke, 1974.

HEESTERS, J. De hononering van de huisarts als vrij beroepsbeoefenar vergeleken met die van de ambtenaar en de werknemer in de gezondheidszorg, Katholieke Hogeschool Tilburg, Reeks "Ter Discussie", 1980a.

HEESTERS, J. p. De opbrengst in de huisartspraktujk, (I), Katholieke Hogeschool Tilburg, Reeks "Ter Discussie", $1980 \mathrm{~b}$.

HEEsTERS, J. P. Aankleden of uitkleden? Katholieke Hogeschool Tilburg, Reeks "Ter Discussie', 1981 .

HCKS, D. Primary health care, a review, London, HMSO, 1976.

HIRSCHI, T. en H. C. SELVIN. Principles of causal analysis, in Lazarsfeld P. F. A. K. Pasanella en M. Rosenberg eds., Continuities in the language of social research, The Free Press, New York, 1972 .

HUGHES M. en W. R. GOVi: Possible causes of the apparent sex differences in physical health: an empirical investigation, American Sociological Review, 44, 1979, 126-146.

HUGHES, M. en W. R. GOVE. Living alone, social integration and mental health, American Journal of Sociology, $87,1981,48-74$.

HUISAKTS REGLSTRATRE COMMISSIE. Richthijnen woor uitschrijven uit het register versus handhaving inschrijwing, Mediscti Contact, 36, $1981,554-555$.

MULL, M. A day with the doctor: Germany, Update, 21, 1980, 607-612.

HYMAN, H. Survey design and analysis, Glencoe, The Free Press, 1955.

JANSEN, M, D. SIKKEL. Verkorte versies van de VOEG-schaal, Gezondheid en Samenleving, 2, 1981, 78-82,

JESSEN, I. L. c.a. Medische consumptie, Rijksumiversiteit Groningen, 1974.

JOHNSTONE, A. en D. GOLDEERG. Psychiatric Screening in general practice, Lancet, 20, 1976. $605-608$.

JoL, C. Samenlevingswormen en welijn, Sociaal Cultureel Kwartalbericht, 2, 1980a, 1, 7-18. IOL, C. Wie heeft er genoeg van het huishouden, Social Cultureel Kwartaalbericht, 2, 1980b, $2,7-16$ 
1OL, C. Dagelijkse bezigheden en welzijn, Sociaal Cultureel Kwartaalbericht, 2, 1980, 3, 8-21. KILPARICK, s. J. The distribution of episodes of illness, a research tool in general practice? Journal of the Royal College of General Practitioners, 25, 1975, 686 690.

KILPATRICK, S. J. An empirical study of the distribution of episodes of illness recorded in the 1970-71 National Morbidity Survey, Applied Statisties, 26, 1977, 26-33.

KILPATRICK, S. J. Consultation frequencies in general practice, Health Services Research, 12 , $1977,284-298$.

KOBRIN, F. E en G. E. HENDERSHOT. DO family ties reduce mortality? evidence from the United States, Journal of Marriage and the Family, 39, 1977, 737-745.

KOHN. R. en K. L. WHTE. Health care: An international study, Oxford Univ. Press, London, 1976. KoOIs, G. A. Sexualiteit, huwelijk en gezin in Nederland, Deventer, 1975.

KRONENFELD, J. J. Sources of ambulatory care and utilization models, Health Services Research, $15,1980,3-20$.

KRUIDENIER, H. J. Een onderzoek natar de factoren die de hoogte van het verwijspercentage beimvloeden, Landelijk Informatie Systeen Ziekenfondsen, 1976.

KuYVEnfoven, M. M. enF. TOUW, orten. Projekt "Pre-medische fase", Deel 1, literatuur-onderzoek, Utrecht, Inst. voor Huisartsgeneeslkunde der Rijksuniversiteit, 1976.

KUYVENHOVEN, M. M. en F. TOUW OTTEN. De verschillen en overeenkomsten in frekwentie wan eerste kontakten tussen agrarische, autochtone en forensengezinnen, Utrecht, Instituut voor huisartsgenceskunde der Rijksuniversiteit "1978.

LAWRENCE, P.S. Methods in the US National Health Interview Survey, paper EEG conference. Brussel, 1975; aangehaald in Nuyens e.a., deel IF.

LORANT, I. H. en L. J. KIMBELL. Determinants of output in group and solo medical practice, Health Services Research. 11, 1976,6-20.

LUFT, H. S. Poverty and health, causes and consequences of health problems, Ballinger, Publ. cy., Cambridge (U.S.A.), 1978.

LUTEYN, Fe relaties tussen ABV, MMPI en NPV, Nederlands Tijdschrift voor de Psychologie, $35,1980,215-222$.

MANNING, W. G., C. N. MORRIS J. P. NEWHOUSE, L. L. ORR, N. DUAN, E. B. KEELER, A. LEIBOWTTZ, K. H. MARQUIS, M. S. MAROUIS en C. E. PHELPS. A two part model of the demand for medical care, preliminary results from the Health insurance studies, in J. van der Gaag en M. Perlman eds., Health, economics, and health economics, North Holland Publishing Cy., Amsterdan, 1981

MARKS, J. N., D. P. GOLDBERG EN W. F. HILLIER, Determinants of the ability of general practitioners to detect psychiatric illness, Psychological Medicine, 9, 1979, 337-353.

Mc KINLAY, J. B. Some approaches and problems in the study of the usie of services, Journal of Health and Social Behavior, 13, 1972, 1.15-152.

MECHANIC D. Sex, illness behavior and the use of health serwices, Social Science and Medicine, $12 \mathrm{~B}, 1978,207-214$

MECHANIC, D. Correlates of physician utilization: Why do major multiwariate studies of physician utilization find trivial psychosocial and organizational effects, Journal of Health and Social Behavior, 20, $1979,387-396$.

MECHANIC D. The experience and reporting of common physical complaints, Journal of Health and Social Behavior, $21,1980,146-155$.

MERENS-RIEDSTRA, H. S. Leven zonder werk; een onderzoek bij arbeidsongeschikten, Tijdschrift voor Sociale Geneeskunde, 58,1980 , supp. 84-86. 
MERENS-RIEDSTR H. H. Leven zonder werk, diss. Rijksuniwersiteit Limburg 1981.

MEYER, J. L. Sociale atlus van de vrouw, Social en Cultureel Planbureau, SCP-cahier 11 , Staatsuitgewerij, "Gravenhage, 1977.

MIZRAHI, A en A. MZRAHI L enquête de 1970 sur les consommations médicalies, Consommation $_{3} 23,1976,3-67$

MOLL WAN CHARANTE, A. Ziektegewoel, ziektegedrag, diss. Utrecht, 1980.

MOOTZ, M. Ziekenfondslidmaatschap en het radplegen van de hüsarts, Medisch Contact, 33 ,

$1978,1465-1468$.

MOOTZ, M. Sociale indicatoren, gezondheidstoestand en verzekeringsworm, Medisch Contact,

$35,1980,857-860$.

MOOTZ, M. De patiënt en zi.jn naasten, diss. Rijksuniversiteit Limburg, 1981 .

MORELLC, D. C. H. G. GAGE en N. A. ROBNSON. Patterns of demand in general practice, Journall of the Royal College of General Practitioners, 20, 1970, 331-342.

MORRIS, J.N. Sociall inequalities undiminished, Tijdschrift woor Sociale Geneeskunde, 58, 1980 , supplement, $13-18$.

NATANSON, C. A Sex, illness and medical care, Social Science and Medicine, 11, 1977, 13-25. NATANSON, C. A. Sex roles as variables in the interpretation of morbidity data" a methodological critique, International Journal of Epidemiology, 32, 1978, 253-262.

NEDERLANDS HUISARTSEN INSTITUUT. Cijfers wit de huisartsenregistratie, vestigingen 3, 1981 . NEVEW, E. J. J. Uitstelduur en praktijkvoering, dissertatie Rijksuniwersiteit Limburg, 1980 .

NEWACHEK, P. W., L. H. BUTLER, A. K. HARPER, D. L. PIONTKOWSKY EN P. E. FRANKS InCOME and illness, Medical Care, 18, 1980, 1165-1176.

NEWHOUSE, J. P. J. E. WARE E C. A. DONALD. How sophisticated are consumets about the medical care delivery system? Medical Care, 19, 1981, 316-328.

NUYENS, Y. e.a. Nationaal Onderzoeksprogramma in de Sociale Wetenschappen van het Koninkrijk België, Project Eerstelijnsgezondheidszorg, Diensten van de Eerste Minister, programmatie van het Wetenschapsbeleid, z.j., z.p. (1979).

NUYENS, Y. De eerste lijn is krom, Van Loghum Slaterus, Deventer, 1980.

NIJHOF, G. Sociale ongelijkheid en psychische storingen, Link, Nijmegen, 1979 (proefschrift). NIyHOF, G. Sociale ongelijkheid, interpretatie en psychische gezondheidsklachten, Tijdschrift voor Sociale Geneeskunde, 58, 1980, supplement, 115-117.

OLIEMANS, A. P. Morbiditeit in de huisartspraktij|k, Stenfert Kroese Leiden, 1969 (proefschrift). OLIEMANS, A. P. en W. VAN DE VEN Morbiditeitsanalyse in een solo huisartspraktijk, Huisarts en

Wetenschap, $18,1975,437-448$.

OFFCE OF POPULATION CENSUSES AND SURVEXS. Morbidity statistics from general practice"

Second National Study, 1970-71, Her Majesty"s Stationary Office, London, 1974.

ORMEL, y. Over neuroticisme gemeten met de vragenlijst; een persoonlijkheidskenmerk of een maat voor psychosociale belasting? Nederlands Tijdschrift voor de Psychologie, 35 , $1980,223-241$

ORMEL, , Moeite met leven of een moeilijk leven, Konstapel, Groningen, 1980 b (proefschrift). PaIs, M. Een vragenlijst voor de (poli-)kliniek inwendige geneeskunde, diss. Leiden, 1977. PARKIN, D. Distance an anfluence on demand in general practice, Journal of Epidemiology and Community Health, 33, 1979, 96-99.

PETERSEN, $c$. Is een volksverzekering tegen ziektekosten economisch haalbaar? "Economisch Statistische Berichten, 67, 1982, 424-431.

PHILIPSEN, H. Afwezigheid wegens ziekte, Wolters/Noordhof, Groningen, 1969 (proefschrift). 
PHIIPSEN, H. De voorwaardelijkheid van algemene uitspraken toegelicht aan de samenhang tussen werkvoldoening en afwezigheid wegens ziekte, Sociologische Gids, 18, 1971, $320-332$.

PHLIPSEN, H. Levensfase, generatie en ziektewerzum, Rijksuniversiteit Limburg/Nederlands Instituut woor Preventieve Gezondheidszorg TNO, 1977.

PLOEG, H. MA VAN DER. Persoonlijkheid en medische consumptie, Swets \& Zeitlinger, Lisse, 1980 (proefschrift).

POMMER, E. J. en C.S VAN PRAAG. Satisfactie en leefsituatie SCP-cahier 13, Sociaal en Cultureel Planbureau, Rijswijk, 1978.

POPPEL, F. WAN. Sociale ongelijkheid voor de dood: nog steeds een realiteit in de westerse wereld, I en II, Demografie, bulletin van het Nederlands Interuniversitair Demografisch Instituut, 32, aug. 1978 , en 33 , sept. 1978.

POSTHUMA. B. H. Invloed van leeftijd en geslacht op verwijscijfers naar medische specialisten.

Instituut voor sociaal medische wetenschap R.U. Groningen, 1976.

POSTHUMA, B. H. en J. VAN DER ZEE. Tussen 1e en 2e echelon 1, Onderzoek op macro-niveau naar verwijs-, opname- en verpleegduurcijfers, Utrecht/Groningen, 1977.

POSTHUM,A, B. H. en I. VAN DER ZEE. Tussen $1 \mathrm{e}$ en 2 e echelon 2, Over praktijkgrootte en produktiecijfers van huisartsen, Utrecht/Groningen, 1978.

POSTHUMA, B. H. en I. VAN DER ZEE. Verwijscijfers en de verkleining van de huisartspraktijk, Gezondheid en Samenleving, 1, 1980, 59-68.

POSThUMA. B. H. Collectivisering van de gezondheidszorg, proefschrift in voorbereiding. RAuPP, J. L. M. Over werkwijzen van huisartsen, diss. Nijmegen, 1971.

ROELINK, H. Privacy van de arts, Tijdschrift voor Sociale Geneeskunde, 59, 1981, 422-427. RUTTEN, F. F. H. The use of health care facilities in The Netherlands, diss. Leiden, 1978.

SCHRIJVERS, G. Regionalisatie en financiering van de Engelse, Zweedse en Nederlandse gezondheidszorg, De: Tijdstroom, Lochem-Poperinge, 1980 (proefschrift).

SELLTIZ, C., M. JAHODA, M. DEUTSCH en S. W. COOK. Research Methods in Social Rellations, Holt; Rinehart, Winston, N.Y.; edition, 1966.

SIERKSMA, R. J. De empirisch-operationele benadering van vervreemding, Mens en Maatschappij, 46, 1971, 42-66.

StKKEL, D. Een verkorting van de VOEG-schial, Sociaal Cultureel Kwartaalbericht, 2, 1980, 3, 22-25.

SLOAN, F. A micro analysis of physicians' hours of work decisions, in, M. Perlman ed., The economics of health and medical care, The Macmillan Press, London and Basingstoke, 1974 .

SMULDERS. P. G. W. De effecten wan maatregelen om het ziekteverzuim te beinvloeden, Leiden, Nederlands Instituut voor Praeventieve Gezondheidszorg/TNO, 1980.

SOCIAAL CULTUREEL RAPPORT. Sociaal Cultureel Rapport 1978 en 1980, Staatsuitgeverij. s-Gravenhage, 1978, 1980.

SONSBEEK, J. L. A. VAN en J. T. P. BONTE. Het ontbreken van differentiële gezondheidsstatistiek, Tijdschrift woor Sociale Geneeskunde, 58, 1980, supplement, $118-121$.

STODDARD BARER. Analyses of demand and utilization through episodes of medical service, in $J$. van der Gaag en M. Perlman eds, Health, economics and health economics, North Holland Publishing Company, Amsterdam, 1981.

TESSLER. R., D. MECHANIC en D. DIMOND. The effect of psychological distress on physician utilixation: a prospective study, Journal of Health and Social Behavior, 17,1976 , 
343-364.

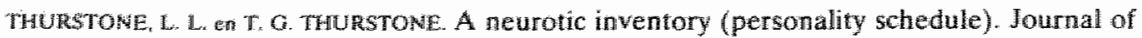

Social Psychology, 1930,3 , aangehaald in Wilde, G. J. S. 1970.

VELDEN, H. G. M. VAN DER. Huisvrouw, huisarts, huisgezin, Dekker en w. Vegt. Nijmegen,

1971 (proefschrift).

VEN, W. F. M. M. WAN DE Effecten van eigen bijdrage in de gezondheidszorg, I, II en III, Medisch Contact, 35, 1980, 155-157, 189-194 en 216-218.

VEN, W. M. M. WAN DE. Ziekenfonds versus particuliere werzekeringen in de gezondheidszorg, en II, Economisch Statistische Berichten, 1981, 524-530 en 552-557.

VEN, W. P. M. VAN DE. F. A. NAUTA, E. C. J. A VAN VLIET En F. F. H. RUTTEN Inventarisatie en achtergronden wan consumptieverschillen tussen ziekenfonds- en particulier verzekerden, Gezondheid en Samenleving, 1, 1980, 224-254.

VEN, W. P. M. M. VAN DE EN B. M. S. VAN PRAAG. Risk aversion and deductibles in private health insurance: application of an adjusted Tobit-model to family health care expenditum res, in $J$. wan der Gaag en M. Perlman eds. Health, economics and health economics, North Holland Publishing Company, Amsterdam, 1981.

VERBRUGGE, LOIS, Females and illness; recent trends in sex differences in the United States, Journal of Health and Social Behavior, $17,1976,387-403$.

VERHAAK, P. F. N. Psychische problemen in de huisartspraktijk, Maandblad Geestelijke Volksgezondheid, $1981,36,31-46$.

VERHOEFF E N. S. Gebruik van gezondheidszorgyoorzieningen in Nederland: een exploratief onderzoek; diss. Nijmegen, 1979.

WLET, R. C. J. A. WAN En W. P. M. M. VAN DE VEN. Analyse wan verschillen in medische comsumptie tussen ziekenfonds- en particulier verzekerden, Gezondheid en Siamenleving, 3 . $1982,54-72$.

WALDRON, I. Why do women liwe longer than men?, Social Science and Medicine, 10, 1976, 349-362

WAN, TH. T, en J. SOIFFER. Determinants of physician utilization, Journal of Health and Social Behavior, 15, 1974, 100-108.

WLDE, $G$ I S Neurotische labiliteit gemeten volgens de vragenlijstmethode, 2 e vermeerderde druk, F. van Rossen, Amsterdarn, 1970. (le druk in 1963).

WHENSKY, G. R. en L. F. ROSSITER. The magnitude and determinants of physicianminitiated visits in the United States, in J, van der Gaag en M. Perlman eds., Health, economics and heath economics, North Holland Publishing Company, Amsterdam, 1981.

Wullus, D. Scientific sociology, Prentice Hall, Englewood Cliffs, New Jersey, 1967.

WILLIGE, G. KAN DE en J. ORMEL. Over dagelijkse problemen en gebeurtenissen, Socical en Cultureel Planbureau, SCP cahiers, nr. 17, Rijswijk, 1979.

wollFE, B. L. Children"s utilization of medical care, Medical Care, 18, 1980, 1196-1207.

WOLFE, $B$, J. WAN DER GAAG. A new health status for children, in J. van der Gadag en $M$.

Perlman, eds., Health, economics and health economics. North Holland Publishing

Company, Amsterdam, 1981.

woonwonTH, R. S. The personal data sheet, Chicago, zonder jaartal, angehaald in: Wilde, $G$.

J. $S .(1970)$

WRIGH, JAMES D. Are working women really more satisfied? Evidence from several national

surveys, Journal of Marriage and the Family, 40, 1978, 301-313.

ZIEKENHONDSRAAD, Jaruerslagen 1970, 1971, Amstelveen. 
ZHELUIS, R. L. Sociale geneeskunde en sociale ongelijkheid in gezondheid, Tijdschrift voor Sociale Geneeskunde, 58, 1980, supplement, 19-32.

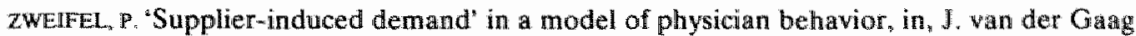
en M. PerIman "eds., Health, economics and health economics, North Holland Publishing Company, Amsterdam, 1981. 


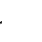


Bijlagen 
Bijlage A: Schematisch overcicht van onderzoeksresultaten op het gebied van de verklaring van lichamelijke klachten

\begin{tabular}{|c|c|c|c|c|c|c|}
\hline $\begin{array}{l}\text { auteur } \frac{f}{5} \text { jartal publicatie } \\
\text { jaartal onderzoek fussen haken } \\
+ \text { vindpladat gegevens }\end{array}$ & $\begin{array}{l}\text { antal }+ \text { soort } \\
\text { ondervraagde per }= \\
\text { sonen }\end{array}$ & $\begin{array}{l}\text { soort } \\
\text { klachtenlijst }\end{array}$ & $\begin{array}{l}\text { verband gevonden } \\
\text { met: } \\
\mathrm{b}=\text { bivariaat } \\
\mathrm{m}=\text { multivariaat } \\
\text { cursief bij } \mathrm{p}<.05\end{array}$ & & $\begin{array}{l}\text { indien } \\
\text { mulivariaat } \\
\text { met constant } \\
\text { houden van: }\end{array}$ & $\begin{array}{l}\text { soort } \\
\text { verband }\end{array}$ \\
\hline $\begin{array}{l}\text { Cassee }(1973(1967) \\
\text { p. } 76 \text { tabel } 20\end{array}$ & $\begin{array}{l}\left.145(300)^{23}\right) \text { pers. } \\
\text { tussen } 21-65 \mathrm{jt} \\
\text { wit Utrecht }\end{array}$ & $\begin{array}{l}\text { VOEG-verkorte } \\
\text { versie } 21 \\
\text { items }\end{array}$ & $\begin{array}{l}\text { leeftijd } \mathrm{f}=.09 \mathrm{~b} \\
\text { geslacht } .03 \mathrm{~b} \\
\text { opleiding }-18 \mathrm{~b}\end{array}$ & & n.v.l. & $\begin{array}{l}\text { product } \\
\text { moment } \\
\text { correlatie }\end{array}$ \\
\hline Jessen, e.a. $1974(1970)$ & $\begin{array}{l}1622 \text { ( } 16 \text { jr en ouder) } \\
\text { geheel Nederland }\end{array}$ & $\begin{array}{c}\text { ABV-N verkorte } \\
\text { ABV-NS versie } \\
23 \\
\text { zwánst } \\
\text { wegende items }\end{array}$ & $\begin{array}{lc} & A B V=N \\
\text { leeftijd } & -.035 \\
\text { geslacht } & 212 \\
\text { opleiding } & .058 \\
\text { inkomen } & -.024 \\
\text { burg, st. } & -.101 \\
\text { part/ZFv. } & -.024 \\
\text { werk/n.w, } & .125 \\
\text { chron.kw. } & -.086 \\
\text { ja-neen } & \\
\text { ziekenhuis } & \\
\text { geweest } & .038\end{array}$ & $\begin{array}{r}A B V-N S \\
.034(\mathrm{~b}) \\
.184(\mathrm{~b}) \\
-.057(\mathrm{~b}) \\
-.072(\mathrm{~b}) \\
-061(\mathrm{~b}) \\
-.064(\mathrm{~b}) \\
.172(\mathrm{~b}) \\
=.180(\mathrm{~b}) \\
\\
-.128(\mathrm{~b})\end{array}$ & n.Y.t. & $\begin{array}{l}\text { product momeni } \\
\text { correlaties }\end{array}$ \\
\hline
\end{tabular}

\section{Aakster, $1972(1968)$}

\$10.6. p. 111 ev

corr. matrix = appendix D
$1552(1039)^{24} 25-65$ ji 56 klachten

Nederlandse bevolking eigen klach=

tenlijst

General Index

of Complaints

-alle frequen-

tie en inten-

siteitsscores

tezamen geteld

\section{gesiacht $136 \mathrm{~b}$}

leeftijd $.065 \mathrm{~b}$

aantal kind. .1/4 b

soc. mobiliteit $.155 \mathrm{~b}$

desintegratie

gezinsleven $.158 \mathrm{~b}$

zie noot 25

product moment.

correlaties en

partiele corr.

coefficienten

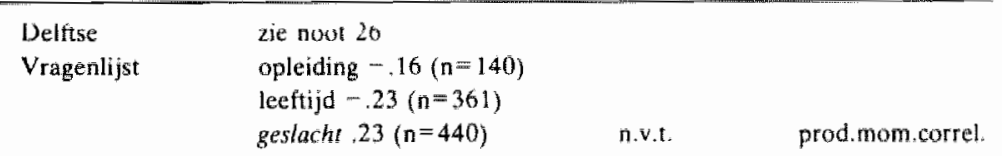

leeftijd (totale groep) $-.10(701)$

beroepsniveau 12 (602)

opleiding. $11(684)$

geen beroep . 15 (388)

\begin{tabular}{|c|c|}
\hline $\begin{array}{l}\text { Ambieft, a. } 4 . .1980(1979) \\
\text { artikel p. } 601\end{array}$ & $\begin{array}{l}2 \text { grocen normalen' } \\
\mathrm{n}=290, \mathrm{n}=440 \text { geen } \\
\text { gadere informatie } \\
\text { bekend dan resp. } \\
\text { afkomstig uit } \\
\text { Groningen en Fries- } \\
\text { land en respondenten } \\
\text { postenquêtes }\end{array}$ \\
\hline
\end{tabular}

Ormel, 1980, (1970,76,77)

$\$ 2 . \bar{p}$ p. 166

$\mathrm{n}=181$ steekproef
(jonger dan 65 jaar)
niet uit zuid(west)
Ned en $\mathrm{N}$ Holland
uit steekproef
uan Ieccen 1074

optelling van

14 items dit

$\mathrm{ABV}-\mathrm{N} \div$

NS tezamen

$\begin{array}{lr}\text { geslacht } & 5 \\ \text { inkomien } & -.12 \\ \text { plattelstad } & .12 \\ \text { niet actief } & -.30 \\ \text { actief } & \\ \text { correlatie }<.10 & \end{array}$

n.y.t. prodmom. 
leeftijd, opleiding.

correlaties

huisvrouwen vs vrouwen

met baan = alleenstaanden

resp. niet alleenstaanden

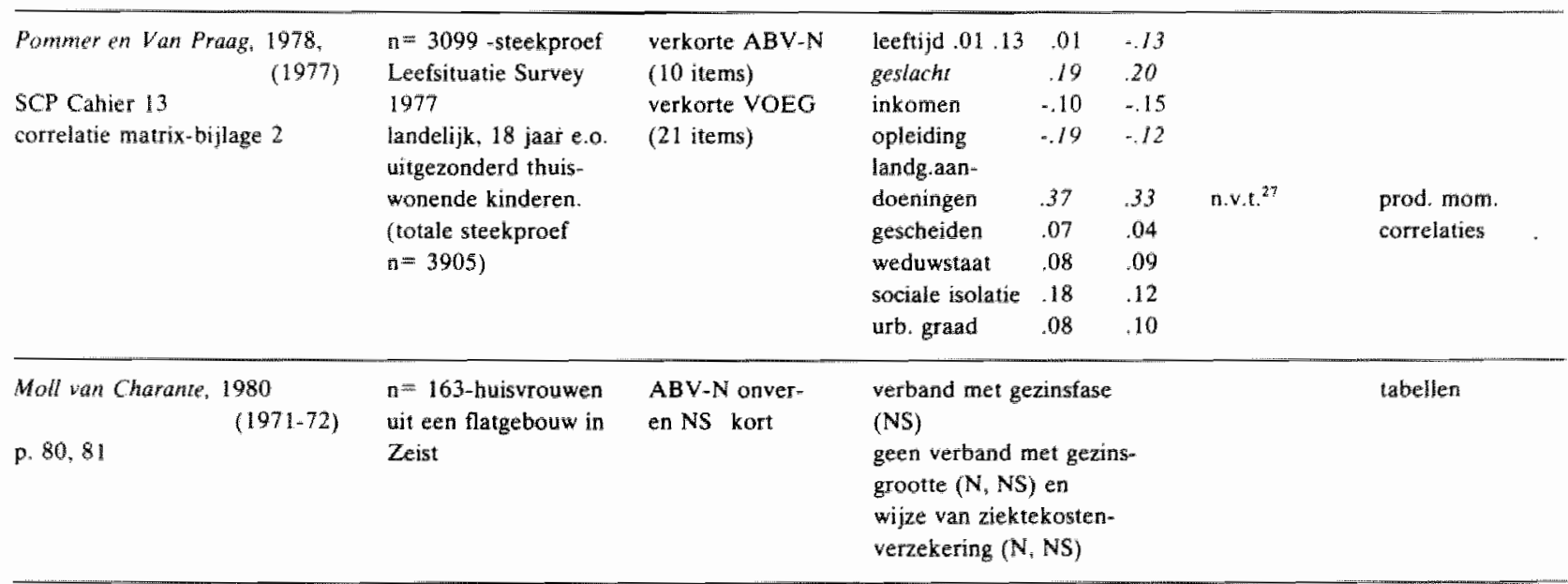

Nuyens e.a., 1979 (1977)

deel 1H.p. 250-275
1745 personeñ vañ

15 jr. en ouder- gesommeerd

spontaan geuite urbaniatie, tabel

leeftijd, toetsing 
Nuyens ea. 1979 (1977)

deel 1H-p. 250-275

tabellen \$ p. $312-346$
1745 personen van

15 ji. en ouder-

Nederlands sprekend;

inwoners van

het Vlaamse landsge-

declte in Belgiè

\section{gesommeerd} spontaan geuite

klachten in ge-

zondheidsdag-

boek uit 9 week

se periode -

soms gemiddeld

aantal klachten

$=$ soms $\%$ klagen-

den gestactin (ni)

Leftijd (\%) - vrouwen

jonger dan 50 jr. is

hoger en

vrouwen $50+$ gemiddeld

mear klachten

mannen $<50$ gemiddeld

meer klachten

Burg: staat - niet gehuwden meer klachten, vooral bij jongeren

Opleiding, SES hoe hoger inkomen

hoe meer

klachten

werk/niet werken - mannen $<50$ jr. niet werken - meer klachten dan werk mannen $>50$ jaar en vrouwen nische morb. tatel

toetsing

lettijd;

gomidueldon

ziektegeschie

deris,

chronische

morbiditeit

urbanisatie,

chronische aan-

doeningen en

ziek tegeschic-

denis eonstant

geslincht, lect ziektegeschicdenis, chro-

nische morb.

geslacht, lext. ziektegeschiedenis, chronische morb.

geslacht, leeft ziektegeschiedenis, chro- 
soon werk - meer dan 9 uur per dag, ploegendienst. $>1 / 4$ uur reistijd meer klachten (eigenlijk alleen $<50 \mathrm{jr}$.

voor jongere mannen de rest te kleine aantallen)

Groolle huishouden vrouwen $<50 \mathrm{jr}$, meer klachten bij kleiner huishouden

Dichtheid voorzieningen meer aanbod (buisararts, spec, rest) meer

klachten geslacht, leeft. ziektegeschiedenis, chronische morb. leeftijd, geslacht, riektegeschiedenis chron. morb.

\section{Andersen en Aday, 1978 .}

(1975-76)
7387 personen (niet in loganithmische inrichtingen) in de U.S.A.; i.v.m. 'oversampling' van verschillende minderheidsgroepen - îs het gewogen aantal $12.085^{29}$ transformatie van aantal ge= uite symptomen en algemeen . oordeel over de gezondheid

$\begin{array}{lc} & \text { alg. } \\ & \begin{array}{c}\text { oordeel } \\ \text { gezondh }\end{array} \\ \text { leeftijd } & .34 \\ \text { opleiding } & -.31 \\ \text { inkomen } & -.26 \\ \text { ras } & .04\end{array}$

symp- partiële coëff. tomen oordeel gezondh. $\quad$ zond ${ }^{30} \mathrm{I}$ .26

$-.07$

$=.10$

$-.11$ sympt. $\quad .409$

inkomen -.090

opleid. $\quad-.191$

ras $\quad-.107$

leeft. $\quad .196$

sympromen

leeftijd $\quad 240$

inkomen -0.71

ras $\quad 0.36$
Nihof, 1979. (?"? 1970?)

correlatie matrix, p.282-83 tabel 7 pág. 95
1544 mannelijke ziekenfondspatiẹnten (nict als zefstandig werkzaam) van $25-65$ jaar uit 5 Rotterdamse huisartspraktijken. Response + selectie (uitsluiting 68 zelf= standigen) uit de gehele populatie $(n=2675)$

\section{ABV}

VOEG

VOEG
Delftse Vra-

genlijst (DV)

Zung-schaal

(depressie)

ABV.NS

Langner schaal

stoningen )

(schizofrenie)

Psychotisme-

schaal

\section{VOEG} vo 
Biflage B: Een hulpmodel voor berekenïng van de variabele 'socialle status' voor niet metr gehuwde en geen beroepsarbeid verrichtende vrouwen.

\section{Overwegingen:}

Bij het toekennen van een statusscore aan niet meer gehuwde en geen beroepsarbeid wernchtende vrouwen met behulp van de scores die gehuwde vrouwen laten zien op een aantal mogelijke indicatoren van 'status', moet men twee zaken goed bedenken.

Ten exste mag men aan "inkomen" niet te veell waarde hechten. Het verlies van een kostwinner betekent meestal een gewoelige inkomensdaling in het gezin en bovendien is de relatie tussen inkomen en status voor gepensioneerden van een andere aard dan voor hen wier partner nog actief aan thet arbeidsproces deelneemt.

Ten tweede is het verband tussen opleiding en status sterk gemeratiegebonden. De oudere generatie heeft in het algemeen een lager opleidingsniveau dan de jongere en kon met naar verhouding minder vooropleiding hogere posities bereiken dan tegenwoordig het gevallis. Dit laatstgenoemde verschijnsel geldt a fortiori voor vrouwen.

In ons hulpmodel zullen we voor ouderen en jongeren de samenhangen apart moeten bezien. $U$ it het onderzoeksmateriaal hebben we de volgende indicatoren gekozen:

1. Netto-inkomen van het gezin (in 7 klassen ondergebracht)

(1) $<15.000$ gulden; (2) $15-17.000 ;$ (3) $17-21.000 ;$ (4) $21-25.000 ;$ (5) $25-31.000 ;$ (6) $31-40.000 ;(7)>40.000$.

2. Aantal jaren dag-opleiding (in $3 \mathrm{klassen}$ )

(1) 9 jaren of minder; (23) $10-12$ jaren; (3) 13 jaren of meer)

3. Aantal duurzame gebruiksgoederen (variërend van 0 tot 14 of meer goederen).

4. Een indlicator voor de kwaliteit van het wonen: een combinatie van waarde van de woning indien men eigenaar was en de bouwtechuische toestand of (voor huurders) de maandelijkse huur gecombineerd met de bouwtechnische toestand. Eigendom van de woning is consequent 1 punt hoger gewaardeerd: uiteindelijk zijn 5 categorieën gewormd.

\begin{tabular}{|c|c|c|c|}
\hline Categorie & waarde eigen woning o & huur per maand & techn. toestand \\
\hline \multirow[t]{2}{*}{1} & $<140.000$ (mediaan) & & slecht (code 1-3) \\
\hline & & tot $250 \mathrm{gld} .(\mathrm{med})$ & slecht tot matig (1-5) \\
\hline \multirow[t]{2}{*}{2} & $<100.000$ & & matig (4-5) \\
\hline & & $>250$ gulden & slecht tot matig (1-5) \\
\hline \multirow[t]{4}{*}{3} & $>140.000$ & & slecht $(1-3)$ \\
\hline & $100-140.000$ & & matig (4-5) \\
\hline & $<100.000$ & & goed $(6-7)$ \\
\hline & & tot 250 gulden & goed $(6-7)$ \\
\hline
\end{tabular}




\begin{tabular}{llll}
\hline Categorie waarde eigen woning of hut per maand & techn. toestand \\
\hline 4 & $>140,000$ & $>250$ gulden & $\begin{array}{l}\text { mattig }(4-5) \\
\text { goed }(6-7)\end{array}$ \\
\hline 5 & $>100.000$ & goed $(6-7)$ \\
\hline
\end{tabular}

Deze variabele (welstand genoemd) is uiteindelijk weer gesplitst in een aantal dummies. Deze variabelen zijn woor de categorie "vrouwen met partner" in verband gebracht met hum hiervoor beschreven sociale status en tot drie categorieèn gereduceerd. In de verschillende analyses (regressie-analyse, gewone kleinste kwadraten, met scalaire en dummy wariabelen) bleken de welstandscategorieën 1 tot 3 geen van elkaar te onderscheiden effect te vertonen, maar wel met de weggelaten klasse (5) en met categorie 4 te verschillen.

De uiteindelijke resultaten zijn als volgt (tabel B.1. - B.6.).

Tabel B.1.; Gehuwde wrouwen van 45 jaar of ouder.

Gemiddelden en standaarddeviaties indicatoren sociale status.

\begin{tabular}{|c|c|c|c|}
\hline & \\
\hline & gemiddelde & Sd & $\mathrm{N}$ \\
\hline afhankelijke variabele status $(1=$ hoog $)$ & 2.31 & .65 & 553 \\
\hline \multicolumn{4}{|l|}{ onafhankelijke variabele } \\
\hline leeftijd (in jaren) & 57.53 & 9.117 & 553 \\
\hline \multicolumn{4}{|l|}{ aantal duurzame goederen } \\
\hline (15 klassen) & 10.08 & 2.603 & 553 \\
\hline \multicolumn{4}{|l|}{ inkomen gezin } \\
\hline (7 klassen $)$ & 3.85 & 2.020 & 475 \\
\hline dummy onderwijs $1=9$ jaar of minder & .74 & .439 & 553 \\
\hline dummy welstand categorie $1-3$ & .36 & .480 & 553 \\
\hline dummy welstand categorie 4 & .21 & .407 & 553 \\
\hline
\end{tabular}


Tabel B.2.: Gehuwde wrouwen van 45 jaar of ouder. Product-moment correlaties tussen indicatoren van socilale status.

$\begin{array}{llllllll}1 & 2 & 3 & 4 & 5 & 6 & 7\end{array}$

1. status $(1=$ hoog, $3=$ lalag $)$

2. leeftijd

$$
\begin{array}{rrrr}
.05 & . & & \\
-.25 & -.14 & . & \\
-.37 & -.41 & -.42 & . \\
.33 & .18 & -.23 & -.33
\end{array}
$$

3. duurzame goederen

4. inkomen gezin

5. dummy weinig onderwijs

$(<9$ jaar $)$

6. welstand laag

$\begin{array}{lllll}.26 & .06 & -.14 & -.22 & -.15\end{array}$

7. welstand midden

$\begin{array}{llllll}.02 & .06 & .10 & .04 & .11 & (-.39)\end{array}$

De hoogste samenhang met status vertoont 'inkomen' $(r=-37)$ maar inkomen neemt bij hogere leeftijd sterk af $(r=-.41)$, evenals het aantal duurzame goederen. Weinig onderwijs ( $<9$ jaar) hangt samen met lage status en een eenvoudige behuizing eveneens.

\begin{tabular}{|c|c|c|c|c|c|c|c|}
\hline \multicolumn{7}{|c|}{$\begin{array}{l}\text { afhankelijke onafhankelijke variabelen } \\
\text { variabele }\end{array}$} & \multirow[t]{2}{*}{$\begin{array}{l}\text { con- } \\
\text { stante }\end{array}$} \\
\hline status & leeftijd & $\begin{array}{l}\text { dummy } \\
<9 \text { jir. } \\
\text { onderwijs }\end{array}$ & inkomen & $\begin{array}{l}\text { duurzame } \\
\text { goederen }\end{array}$ & $\begin{array}{l}\text { welstand } \\
\text { laag }\end{array}$ & $\begin{array}{l}\text { weistand } \\
\text { midden }\end{array}$ & \\
\hline B & -.0139 & .313 & -.089 & -.042 & .272 & .179 & 3.515 \\
\hline Sd & 0033 & .0604 & .0146 & .0118 & .0579 & .0664 & .2866 \\
\hline$T$ & 4. 19 & 5.18 & 6.09 & 3.5 & 4.71 & 2.69 & 12.26 \\
\hline
\end{tabular}

De schattingsresultaten zijn als volgt:

Tabel B.3.: Schattingsresultaten hulpmodel van de status van getrouwde vrouwen van 45 jaa.r of ouder

Multiple R. $51, \overline{\mathrm{R}}^{2}=.26, \mathrm{~N}=553$

\section{Commentaar:}

Voor de groep boven de 45 jaar blijkt leeftijd toch een relatie met status te hebben; hoe ouder hoe hoger in het algemeen. Een (hier niet gepresenteerde) stapsgewijze versie van deze 
analyse laat zien dat dit komt doordat het oorspromkeljke verband versluierd wordt ondat oudere mensen een lager inkomen en weinig duurzame goederen bezitten.

Voor de groep vrouwen onder de 45 jar is het model eenvoudiger. Opleiding is een scalaire wariabele en hoeft niet gesplitst te worden in meer of minder dan 9 jaar dagonderwijs.*) De variabele "aantal duurzame goederen" geeft naast inkomen geen informatie. Leeftijd blijkt in deze categorie (tot 45 jaar) geen effect te hebben.

*) N.B. Men moet bedenken bij de interpretatie van de resultaten dat "onderwijs' hier anders is gescored dan bij de oudere vrouwen. Daar hebben we een dummy variabele ingevoerd die de warde 1 aannam bij weing onderwijs, hier loopt de score van weinig naar veel. Het teken is dus precies omgekeerd.

Tabel B.4.: Gehuwde vrouwen jonger dan 45 jaar. Gemiddelden en standaarddeviaties vam de indicatoren woor sociale status

\begin{tabular}{lcrc}
\hline Variabele & Gemiddelde & Sd & N \\
\hline Status & & & \\
$(\mathbb{1}=$ hoog, 3= laag) & 2.31 & .68 & 801 \\
Inkomen (7 klassen) & 4.44 & 1.49 & 698 \\
Onderwijs (1 = weinig, 3 = veel) (3 klassen) & 1.58 & .67 & 801 \\
Welstand laag & .28 & .45 & 801 \\
Welstand midden & .25 & .43 & 801 \\
\hline
\end{tabular}

Tabel B.5.: Gehuwde wrouwen jonger dan 45 jaar. Product-moment correlaties indicatoren sociale status

\begin{tabular}{lrrrrr}
\hline & 1 & 2 & 3 & 4 & 5 \\
\hline 1. status & & & & & \\
2. inkomen & -35 & & & \\
3. onderwijs & -.30 & .22 &. & \\
4. welstand laag & .26 & -.16 & -12 & \\
5. welstand midden & -.02 & -.01 & .01 & $(.36)$ \\
\hline
\end{tabular}


Tabel B.6. Hulpmodel status gehuwde vrouwen jonger dan 45 jaar. Schatingsresultaten

\begin{tabular}{lccccc}
$\begin{array}{l}\text { ahankelijke } \\
\text { Wariabele }\end{array}$ & \multicolumn{3}{c}{ onafhankelijke variabellen } & Constante \\
\hline Status & Inkomen & Onderwijs & $\begin{array}{c}\text { Welstand } \\
\text { laag }\end{array}$ & $\begin{array}{c}\text { Welstand } \\
\text { midden }\end{array}$ \\
\hline $\mathrm{B}$ & & & .337 & .151 & 3.077 \\
$\mathrm{Sd}$ & -.123 & -.225 & .0518 & .0532 & .0855 \\
$\mathrm{~T}$ & .0148 & .0326 & 6.50 & 2.83 & 35.97 \\
\hline
\end{tabular}

Multiple $\mathrm{R}_{\mathrm{n}}=.45 \overline{\mathrm{R}}^{2}=.21 \mathrm{~N}=801$

Op grond wan de gevonden resultaten is de status berekend voor degenen aan wie het CBS geen code heeft toegekend.

\section{Bijlage C: Niet in de tekst vermelde resultaten behorende bij hoofdstuk 6.}

In deze bijage zijn enkele resultaten vermeld, die niet wolledig in de tekst zijn opgenomen. Ten eerste de bij figur 6.2-6.8 behorende waarden; nl. de proportie chronische aandoeningen per leeftijdsklasse (tabel C1), naar leeftije en geslacht (tabel C2), naar leeftijd en socialle status (tabel C3) en naar leeftijd, gesiacht en sociale status (tabel $\mathrm{C4}$ ).

Vervolgens de product-monent correlatie matrix van de onafhankelijke en afhankelijke variabelen in het klachtenmodel (tabel C5).

Als derde de schattingstesultaten van CHRON en ABVN met alle gepredetermineerde variabelen (tabel C6).

Ten vierde de frequentieverdeling van de $V O E G$-scores en ten vijfde schattingsresultaten in het tweede stadium met verschillende transformaties van de VOEG.

ad 1. De bij figuur 6.1-6.8 behorende waarden. Proporties chronische patienten per leeftijd/ geslacht/status categorie. LSO 1977.

Tabel C1: Proportie chronische patiënten per leefrijdscategorie. LSO 1977 (figuur 6.2)

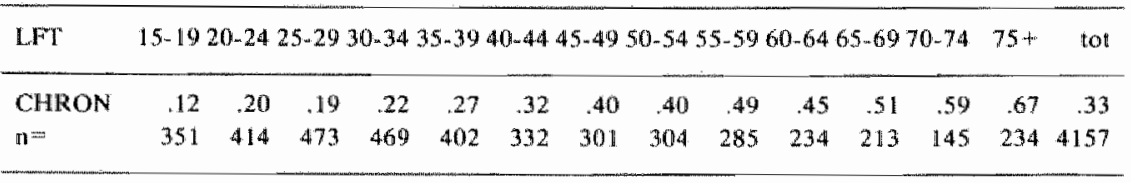


Tabel C2: Proportie chronische patiënten per leeftijdscategorie woor mannen en vrouwen LSO 1977 (figuur 6.3)

\begin{tabular}{lrrrrrrrrrrrrrrrrr}
\hline LFT & $15-19$ & $20-24$ & $25-29$ & $30-34$ & $35-39$ & $40-44$ & $45-49$ & $50-54$ & $55-59$ & $60-64$ & $65-69$ & 70.74 & $75+$ & 100 \\
\hline $\begin{array}{l}\text { mannen } \\
\mathrm{n}=\end{array}$ & 111 & .15 & .18 & .17 & .25 & .29 & .39 & .38 & .48 & .45 & .47 & .54 & 57 & .30 \\
& 185 & 198 & 248 & 239 & 214 & 181 & 145 & 159 & 129 & 133 & 100 & 61 & 99 & 2091 \\
\hline $\begin{array}{l}\text { vrouwen } \\
\mathrm{n}=\end{array}$ & .13 & .24 & .20 & .27 & .28 & .35 & .40 & .43 & .51 & .46 & .55 & .63 & .66 & 36 \\
& 166 & 216 & 225 & 230 & 188 & 151 & 156 & 145 & 156 & 101 & 113 & 84 & 135 & 2066 \\
\hline
\end{tabular}

Tabel C3: Proportie chronische patiênten per leeftijdscategorie en sociale status LSO 1977 (figuur 6.4)

\begin{tabular}{|c|c|c|c|c|c|c|c|c|}
\hline LFT & & $15-2.4$ & $25-34$ & $35-44$ & $45-54$ & $55-64$ & $65+$ & totaal \\
\hline \multirow[t]{2}{*}{ SES-hoog } & & .10 & .14 & .20 & .39 & .45 & .49 & .26 \\
\hline & $n=$ & 60 & 195 & 185 & 149 & 91 & 39 & 719 \\
\hline \multirow[t]{2}{*}{ SES-midden } & & .17 & .20 & .24 & .38 & .43 & .59 & 31 \\
\hline & $n=$ & 375 & 355 & 273 & 216 & 199 & 291 & 1709 \\
\hline \multirow[t]{2}{*}{ SES-laag } & & .17 & .24 & .40 & .43 & .53 & .57 & .37 \\
\hline & $\mathrm{n}=$ & 330 & 392 & 276 & 240 & 229 & 262 & 1729 \\
\hline \multirow[t]{2}{*}{ Totaal } & & .16 & .20 & .29 & .40 & .48 & .57 & .33 \\
\hline & $\mathrm{n}=$ & 765 & 942 & 743 & 605 & 519 & 592 & 4157 \\
\hline
\end{tabular}




\begin{tabular}{|c|c|c|c|c|c|}
\hline $\bar{E}$ & $\frac{5}{\frac{5}{5}}$ & 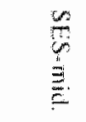 & $\frac{\infty}{E}$ & $\underset{x}{x}$ & 5 \\
\hline$=$ & 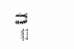 & $=$ & $\overrightarrow{i i}$ & & \\
\hline 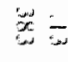 & $\bar{\Xi}$ & $\bar{x}$ & $w 5$ & 3 & \\
\hline$x_{0}^{\infty}$ & $\bar{\Xi}$ & $\bar{x}$ & $\Xi 气$ & $<$ & $s$ \\
\hline$\frac{\pi}{x}$ & $\Xi$ & $\underline{E}$ & $\Phi=$ & 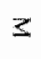 & \\
\hline 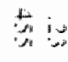 & $\bar{E}_{i}$ & 关 & $\mathscr{n}_{n}$ & $<$ & $\underline{w}$ \\
\hline 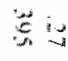 & $\pm \infty$ & $\bar{\alpha}$ & $F_{5}$ & $\geq$ & \\
\hline 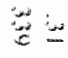 & Fis & $\bar{s}$ & 必 & $<$ & \pm \\
\hline 崖萂 & $\overline{0}$ & $\vec{x}$ & $\overline{\bar{E}}$ & 3 & \\
\hline 志 & $\bar{x} ;$ & 5 & 5 & $<$ & $E$ \\
\hline 怘士 & $=$ & $\infty$ & 昰心 & 3 & \\
\hline$U_{s}$ & $\equiv$ & $\overline{5}$ & 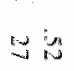 & $\sigma$ & $\$$ \\
\hline 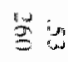 & $\bar{c} \bar{c}$ & $I:$ & 证 & 3 & \\
\hline 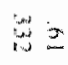 & 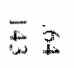 & 50 & 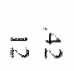 & $<$ & $n$ \\
\hline$\underline{E}$ & 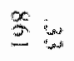 & $y$ & $\bigcup_{\Delta}$ & 3 & \\
\hline$\frac{2}{5}$ & $x^{\infty}$ & $\underset{\alpha}{\infty}$ & $\frac{\omega}{10}$ & $<$ & 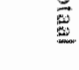 \\
\hline 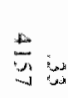 & $\overline{\mathrm{v}}$ & $\vec{z}$ & $\exists$ & & 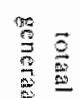 \\
\hline
\end{tabular}

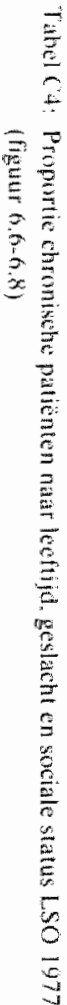




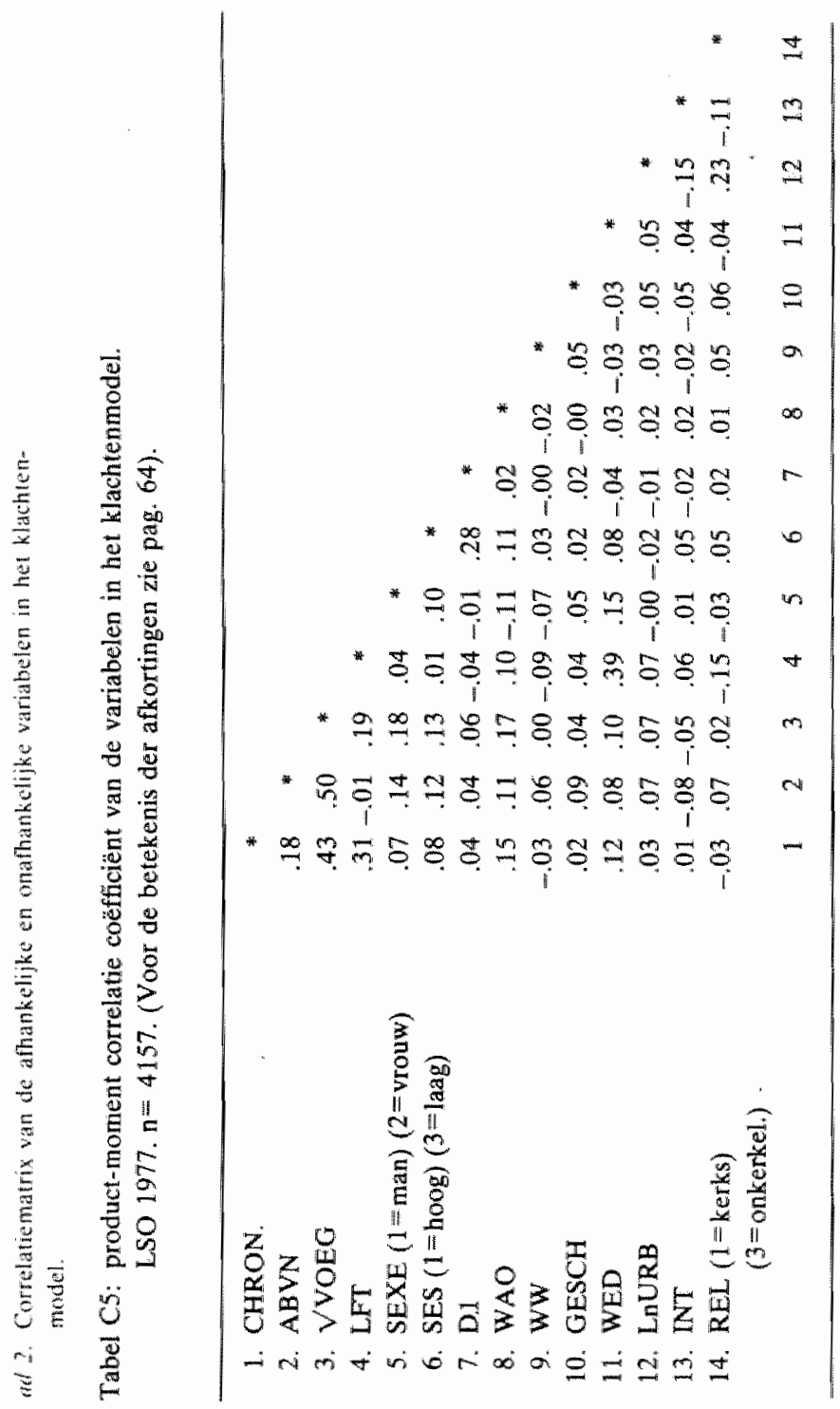


ad 3.

Tabel C6: Sichattingresultaten CHRON en ABVN met alle gepredetermineerde variabelen B-coëfficiènten en $\mathbb{T}$-waarden (gewone kleinste kwadraten) LSO $1977 n=4157$.

\begin{tabular}{cccc}
\hline \multicolumn{3}{c}{ CHRON } & \multicolumn{3}{c}{ ABVN } \\
\hline $\mathrm{B}$ & $\mathrm{T}$ & $\mathrm{B}$ & $\mathrm{T}$ \\
\hline $78 \mathrm{E}-02$ & 18.40 & $-.42 \mathrm{E}-02$ & -2.64
\end{tabular}

\section{SEXE}
(1=man; $2=$ vrouw)
$60 \mathrm{E}-01$
4.28
.48
8.43

\section{SES}

$(1=h o o g ; 3=$ laag)

$.31 E-01$

3.13

.21

$5.63^{\prime \prime}$

D) 1

\begin{tabular}{lcccc} 
(LFT35-44 j. SES=3) & $.75 \mathrm{E}-01$ & 2.62 & .11 & 1.01 \\
\hline WAO & .33 & 7.89 & 1.17 & 7.45 \\
\hline WW & $-.14 \mathrm{E}-01$ & -.25 & .84 & 3.96 \\
\hline GESCH & $-.14 \mathrm{E}-01$ & -.24 & 1.02 & 4.45 \\
\hline WED & $-.12 \mathrm{E}-01$ & -.40 & .52 & 4.50 \\
\hline LnURB & $.30 \mathrm{E}-02$ & .60 & $.57 \mathrm{E}-01$ & 3.02
\end{tabular}

\section{INT}

$(1=$ zwak; $9=$ sterk $)$

$-.22 \mathrm{E}-02$

$-.72$

$-.58 \mathbb{E}-01 \quad-5.02$

REL

( $1=$ kerks; $3=$ onkerkel.

$.71 \mathrm{E}-02$

.73

$.99 \mathrm{E}-01$

2.67

\section{CONST}

$-21$

10.77

1.93

7.86

Schattings-

parameters

$\mathbf{R}^{2}=.12$

$n=4.57$

$\tilde{R}^{2}=.07$

$m=41.57$ 
ad 4. Frequentieverdeling van de VOEG-scores in het LSO 1977.

Tabel C7: Frequentieverdeling wan de VOEG-scores in het LSO 1977. $n=4157$.

\begin{tabular}{rrrrrr}
\hline Score & $\mathrm{n}$ & $\%$ & score & $\mathrm{n}$ & $\%$ \\
\hline 0 & 959 & 23.07 & 13 & 40 & 0.96 \\
1 & 607 & 14.60 & 14 & 34 & 0.82 \\
2 & 490 & 11.79 & 15 & 37 & 0.89 \\
3 & 424 & 10.20 & 16 & 17 & 0.41 \\
4 & 329 & 7.91 & 17 & 13 & 0.31 \\
5 & 256 & 6.16 & 18 & 8 & 0.19 \\
6 & 243 & 5.85 & 19 & 3 & 0.07 \\
7 & 168 & 4.04 & 20 & 3 & 9.07 \\
8 & 148 & 3.56 & 21 & 3 & 0.07 \\
9 & 131 & 3.15 & & & \\
10 & 97 & 2.33 & onbekend & 10 & 0.24 \\
11 & 82 & 1.97 & & & \\
12 & 55 & 1.32 & Totaal: 4157 & & \\
\hline
\end{tabular}


ad 5. In onderstande tabel presenteren wij schatingsresultaten wit verschillende transformaties yan de VOEG. De verklaarde variantie blift ongeveer constant (de variatie zitin de 3 e decimaly. matr de $T$-waten voor de worreftransformate zijn iets mooier.

Tabel C8: Sehattingsresultaten 2 e stadium: verschillende transformaties VOEG met ABV en CHRO

\begin{tabular}{|c|c|c|c|c|c|}
\hline & 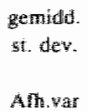 & 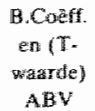 & $\begin{array}{l}\text { B.Coeff } \\
\text { mon (T- } \\
\text { cHRorde) } \\
\text { CHRO }\end{array}$ & $\begin{array}{c}\text { Constante } \\
\text { en (T) } \\
\text { wararde) }\end{array}$ & 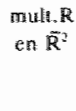 \\
\hline VOEO zander transtormatie & $\begin{array}{l}3.70 \\
3.855\end{array}$ & $\begin{array}{l}1.47 \\
1.2 \%\end{array}$ & $\begin{array}{r}5.24 \\
(4.23)\end{array}$ & $\begin{array}{r}-3.22 \\
(-7.24)\end{array}$ & $\begin{array}{l}32 \\
.10\end{array}$ \\
\hline Alle scores $>12=12$ & $\begin{array}{l}3.54 \\
3.42\end{array}$ & $\begin{array}{r}1.32 \\
(11.42)\end{array}$ & $\begin{array}{c}4.70 \\
(14.403\end{array}$ & $\begin{array}{l}-2.67 \\
-6.79\end{array}$ & $\begin{array}{l}.32 \\
.10\end{array}$ \\
\hline V(VOEG) & $\begin{array}{r}202 \\
92\end{array}$ & $\begin{array}{r}32 \\
(11.39)\end{array}$ & $\begin{array}{r}1.26 \\
(14.77)\end{array}$ & $\begin{array}{r}.46 \\
(4.75)\end{array}$ & $\begin{array}{l}33 \\
.80\end{array}$ \\
\hline Lafl (Woeg + 1 ) & $\begin{array}{r}1.21 \\
87\end{array}$ & $\begin{array}{r}33 \\
(11.43)\end{array}$ & $\begin{array}{c}1.23 \\
(14.76)\end{array}$ & $\begin{array}{c}-.36 \\
(-3.68)\end{array}$ & $\begin{array}{l}.33 \\
.10\end{array}$ \\
\hline score ovs rest (1) & $\begin{array}{l}.77 \\
.42\end{array}$ & $\begin{array}{r}.096 \\
\quad 6.54)\end{array}$ & $\begin{array}{r}43 \\
(10.49)\end{array}$ & $\begin{array}{r}.25 \\
(5.74)\end{array}$ & $\begin{array}{l}.22 \\
.05\end{array}$ \\
\hline $\begin{array}{c}\text { score }<\text { ? (mediann) }=0 \\
>2\end{array}$ & $\begin{array}{l}.50 \\
.50\end{array}$ & $\begin{array}{c}17 \\
(9.77)\end{array}$ & (111. .600 & $\begin{array}{r}-.27 \\
(-4.67)\end{array}$ & $\begin{array}{l}.27 \\
.07\end{array}$ \\
\hline $\begin{aligned} \operatorname{secte}< & <5(75 \%)=0 \\
>5 & =1\end{aligned}$ & $\begin{array}{l}.26 \\
.44\end{array}$ & $\begin{array}{r}.13 \\
(8.95)\end{array}$ & $\begin{array}{c}.52 \\
(12.22)\end{array}$ & $\begin{array}{r}-.39) \\
(-7.53)\end{array}$ & $\begin{array}{l}.27 \\
.07\end{array}$ \\
\hline $\begin{array}{l}\text { Alleen woor pers. met } \\
\text { VOEG }>1\end{array}$ & $\begin{array}{l}4.82 \\
3.75\end{array}$ & $\begin{array}{c}1.26 \\
(8.71)\end{array}$ & $\begin{array}{c}3.80 \\
(9.71)\end{array}$ & $\begin{array}{c}-1.06 \\
(-2.14)\end{array}$ & $\begin{array}{l}.27 \\
.07\end{array}$ \\
\hline $\begin{array}{l}\text { iden torate alle score } \\
>12=12\end{array}$ & $\begin{array}{l}4.60 \\
3.22\end{array}$ & $\begin{array}{c}1.09 \\
(8.83)\end{array}$ & $\begin{array}{l}3.41 \\
9.69)\end{array}$ & $\begin{array}{r}-50 \\
(-1.16)\end{array}$ & $\begin{array}{l}.27 \\
.07\end{array}$ \\
\hline $\begin{array}{l}\text { idem rofar noet } \\
\text { (WOEO) }\end{array}$ & $\begin{array}{r}2,32 \\
.844\end{array}$ & $\begin{array}{r}26 \\
(8.09)\end{array}$ & $\begin{array}{c}.86 \\
(9.23)\end{array}$ & $\begin{array}{r}1.08 \\
(9.59)\end{array}$ & $\begin{array}{l}.25 \\
.06\end{array}$ \\
\hline
\end{tabular}

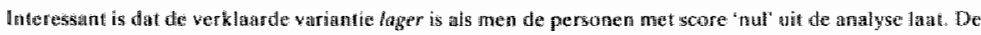

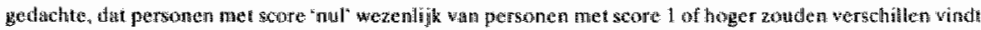
vin dezo resuliaten geen grond. 
Bijlage D: Beschrijving resultaten factoranalyse van de verkorte VOEG.

Tabel D1: Gemiddelden en standaarddeviaties 21 items - LSO $1977 n=4147$

notatie

gemidd. st.dew.

1. Is uw eetlust minder dan u normaal acht

EETLUST

1.91

.29

2. Hebt u nogal eens een opgezet of drukkend gevoel in de maagstreek

3. Bent u gauw kortademig

MAAGDRUK $\quad 1.79 \quad .40$

4. Hebt u nogal eens pijn in de borst of hartstreek

KORTADEM

1.81

BORSPIJN

$1.86 \quad .35$

5. Hebt u vak een vieze of zoetige smaak in uw mond

VIEZOET

1.92

6. Hebt u nogal eens hattkloppingen of bonzingen in de hartstreek

HARTKLOP

$1.85 \quad .36$

7. Hebt u het nogal eens benauwd op de borst

NAUWBORS

8. Hebt u nogal eens klachten over pijn. in botten en spieren:

$\begin{array}{lll}\text { SPIERP } & 1.67 & .47 \\ \text { MOE } & 1.69 & .46 \\ \text { HOOFPIJN } & 1.69 & .46 \\ \text { BUIKLAST } & 1.89 & .31 \\ \text { RUGPIIN } & 1.73 & .44 \\ \text { MAAGLAST } & 1.90 & .32 \\ & & \\ \text { TINTEL } & 1.81 & .39\end{array}$

15. Voelt u zich gauwer moe dan u normaall acht

GAUWMOE

DUIZELIG

16. Bent u nogal eens duizelig

LUSTLOOS

18. Hebt u nogal eens magklachten MAAGKLG

19. Voelt u zich nogal eens slaperig of suffig

SUFFIG

20. Stat ut in de regel "s-ochtends moe en niet uitgerust op

MOEOP

21. Hebt u nogal eens pijn in uw matagstreek

MAAGPIJN

1.92 
Tabel E1: Kerngegevens uit het 2nd National Morbidity Survey per leeftijds-/geslachtsgroep. Engeland en Wales $1970 / 1971$ zie grafiek $10.1 \mathrm{en} 10.3$.

\begin{tabular}{|c|c|c|c|c|c|c|c|c|c|c|}
\hline & & $\mathrm{A}$ & B & $C$ & $\mathrm{D}$ & $E$ & $F$ & $G$ & $\mathrm{H}$ & $I$ \\
\hline \multirow{2}{*}{$0-4 \mathrm{jr}$} & $\mathbf{M}$ & 2.87 & .10 & .81 & 3.79 & 17.0 & 20.3 & 67.9 & 44.2 & 11125 \\
\hline & $\mathrm{V}$ & 2.67 & .09 & .69 & 3.47 & 17.1 & 12.9 & 45.0 & 51.2 & 10475 \\
\hline \multirow{2}{*}{$5-14 \mathrm{jr}$} & $\mathrm{M}$ & 1.43 & .06 & .43 & 1.92 & 14.7 & 8.6 & 50.5 & 46.0 & 24858 \\
\hline & $\mathrm{V}$ & 1.46 & .06 & .41 & 1.93 & 13.1 & 7.3 & 47.1 & 50.7 & 23290 \\
\hline \multirow{2}{*}{$15.24 \mathrm{jr}$} & $\mathrm{M}$ & 1.20 & .07 & .55 & 1.82 & 6.5 & 6.0 & 57.3 & 53.3 & 21027 \\
\hline & $\mathrm{V}$ & 2.18 & .19 & 1.46 & 3.84 & 8.0 & 21.6 & 109.5 & 215.3 & 21799 \\
\hline \multirow{2}{*}{$25-44 \mathrm{jr}$} & $\mathrm{M}$ & 1.17 & .10 & .83 & 2.10 & 6.4 & 9.4 & 77.4 & 76.2 & 36434 \\
\hline & $\mathrm{V}$ & 2.05 & .25 & 1.49 & 3.80 & 9.0 & 17.0 & 124.1 & 212.8 & 38419 \\
\hline \multirow{2}{*}{$45-64 j r$} & $\mathrm{M}$ & 1.20 & .24 & 1.57 & 3.01 & 12.5 & 22.6 & 98.1 & 100.0 & $\begin{array}{ll}33 & 182\end{array}$ \\
\hline & $\mathrm{V}$ & 1.55 & .30 & 1.48 & 3.33 & 12.3 & 15.3 & 101.2 & 142.0 & 35436 \\
\hline \multirow{2}{*}{$65-74 \mathrm{jr}$} & $\mathbf{M}$ & 1.32 & .40 & 1.98 & 3.70 & 30.6 & 49.5 & 112.0 & 109.8 & 9332 \\
\hline & $\mathrm{V}$ & 1.41 & .45 & 1.95 & 3.81 & 29.4 & 31.1 & 96.3 & 118.5 & 13040 \\
\hline \multirow{2}{*}{75 jr e.o. } & $\mathrm{M}$ & 1.43 & .50 & 2.56 & 4.51 & 55.6 & 78.7 & 98.5 & 80.5 & 4388 \\
\hline & $\mathrm{V}$ & 1.38 & .58 & 2.51 & 4.46 & 611.0 & 52.4 & 88.4 & 83.0 & 9442 \\
\hline
\end{tabular}

$A=$ nieuwe episoden in tel jaar (eerste contacters)

B $=$ episode uit jaar voor teljaar (chronische problemen)

$\mathrm{C}=$ terugbestelcontacten

(consultaties-minus-episoden)

per ingeschreven patiënt

$D=$ consultaties $(A+B+C)$

$\mathrm{E}=$ percentage consultaties buiten praktijkpand (visites)

$F=$ acute opnamen

$\mathrm{G}=$ poliklinische verwijzingen

$\mathbf{H}=$ verwijzingen voor onderzoek

per 1000 patiënten

$1=$ antal personen in de betreffende leeftijdsgroep 
Figuur E 1
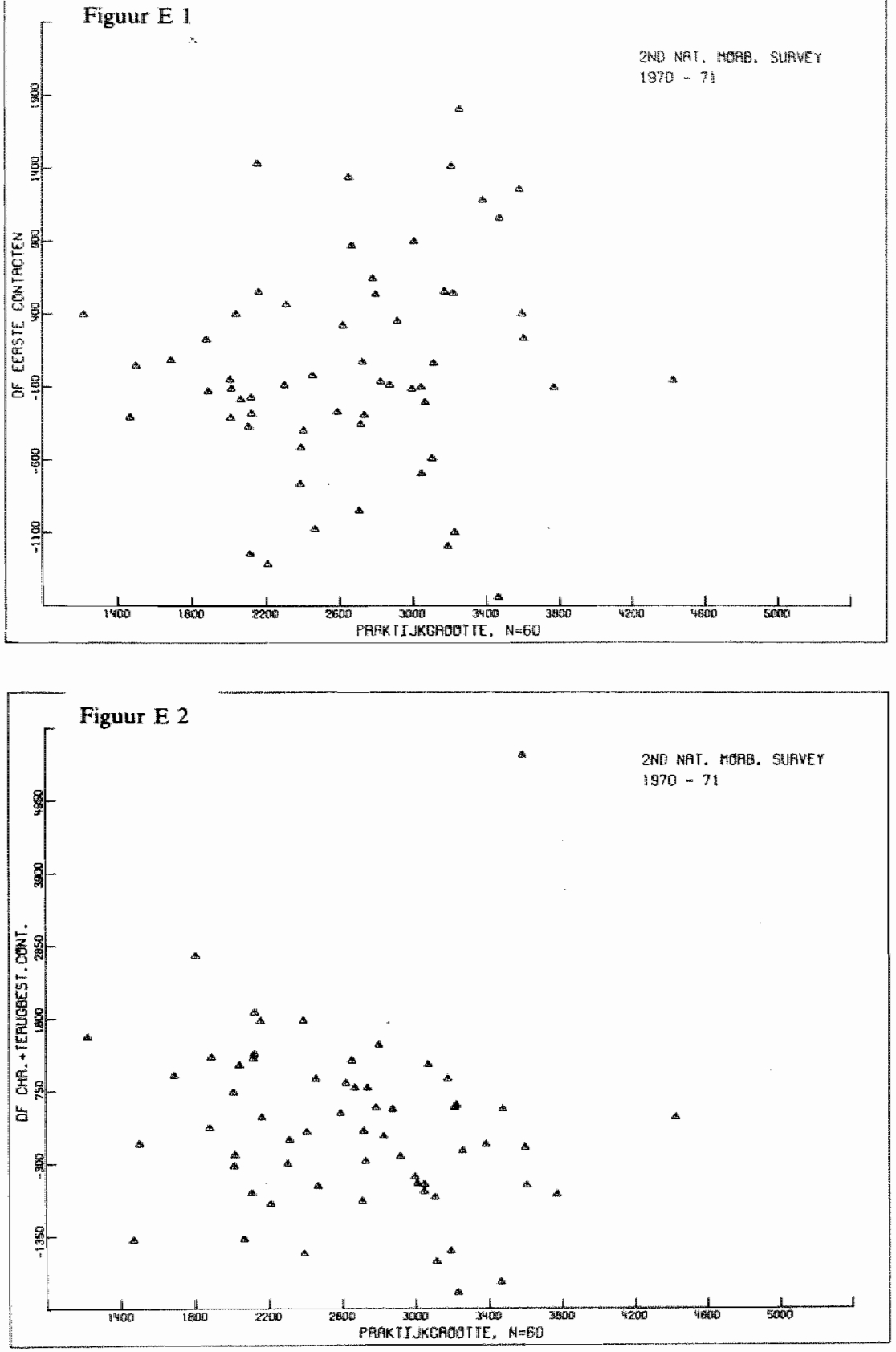


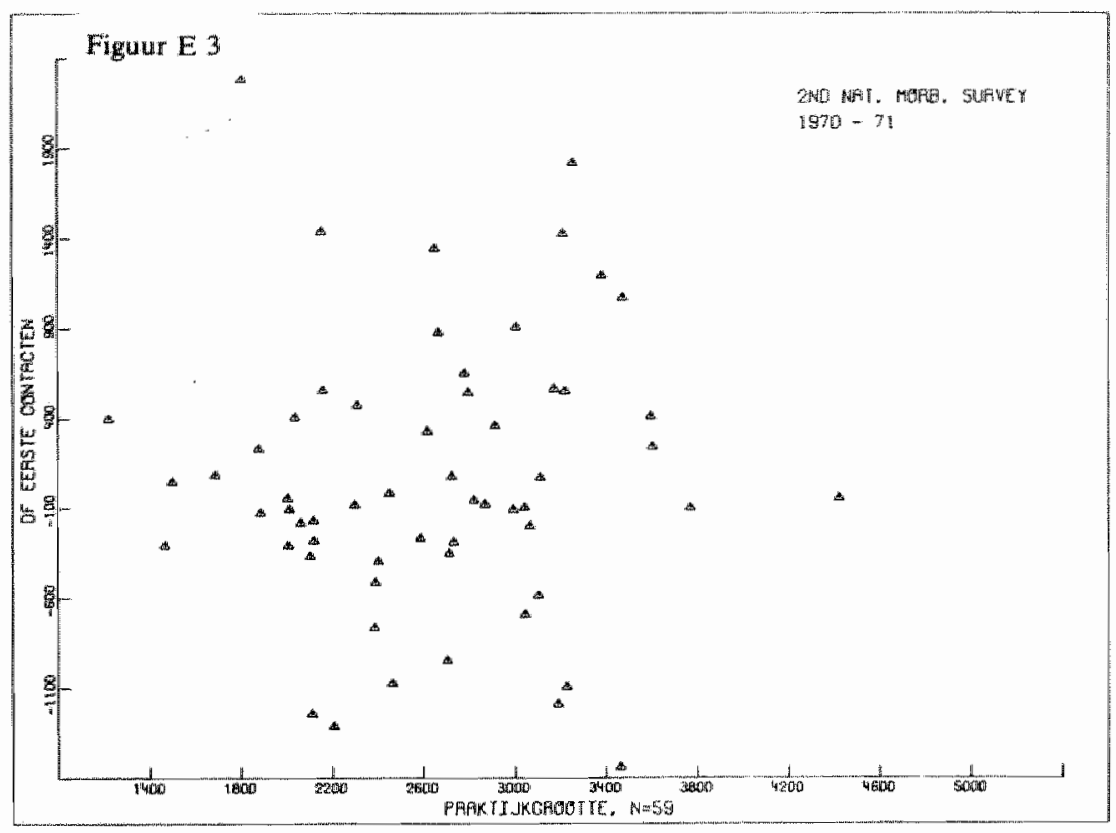

Figuur E 4

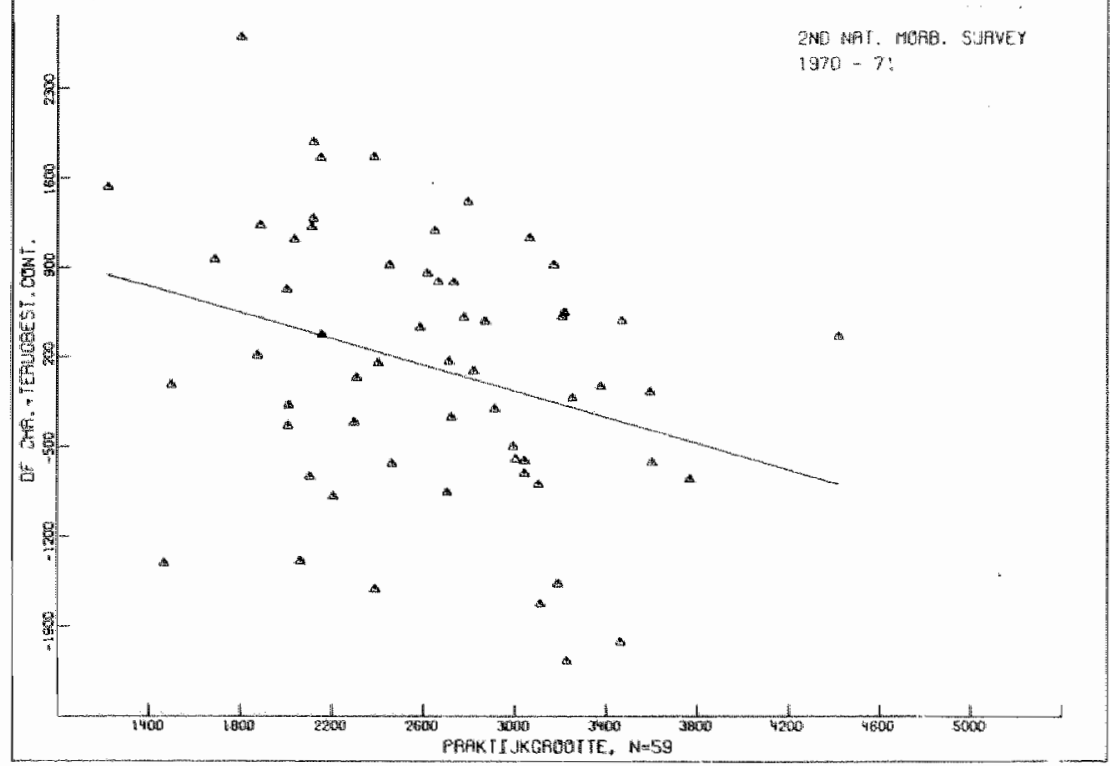


Figuur E1-4 Grafische weergave van het verband tussen grootte van de huisartspraktijk en het aantal contacten op initiatief van patiënt en huisarts voor alle praktijken $(n=60)$ en alle praktijken minus én extreme waarde $(n=59)$.

Bijlage F: Enkele niet in de tekst gepubliceerde tabellen behorende bij hoofdstuk XI, doktersbezoek in het Leef Situatie Onderzoek 1977.

In deze bijlage vermelden we de correlatiematrix voor alle in hoofdstuk 11 behandelde variabelen (tabel $F 1$ ) en vervolgens laten we in figuur $F \|$ zien wat de precieze relatie is tussen VOEG, bezoek aan de huisarts en bezoek aan huisarts en/of specialist.

Figuur FI: Proportie personen met contact met huisarts en/of specialist per VOEG-score.

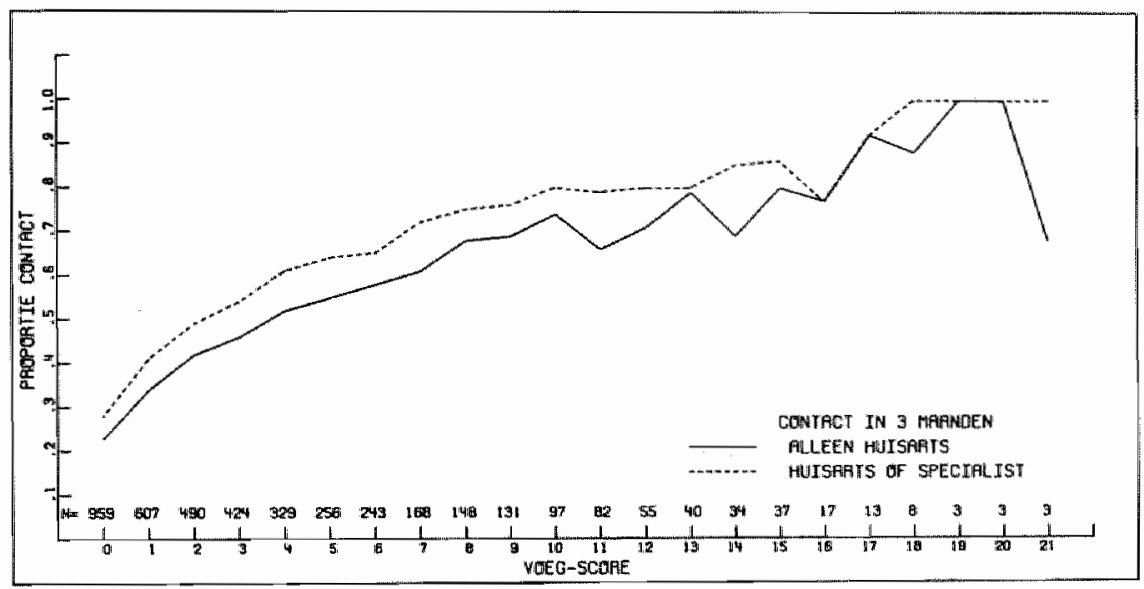




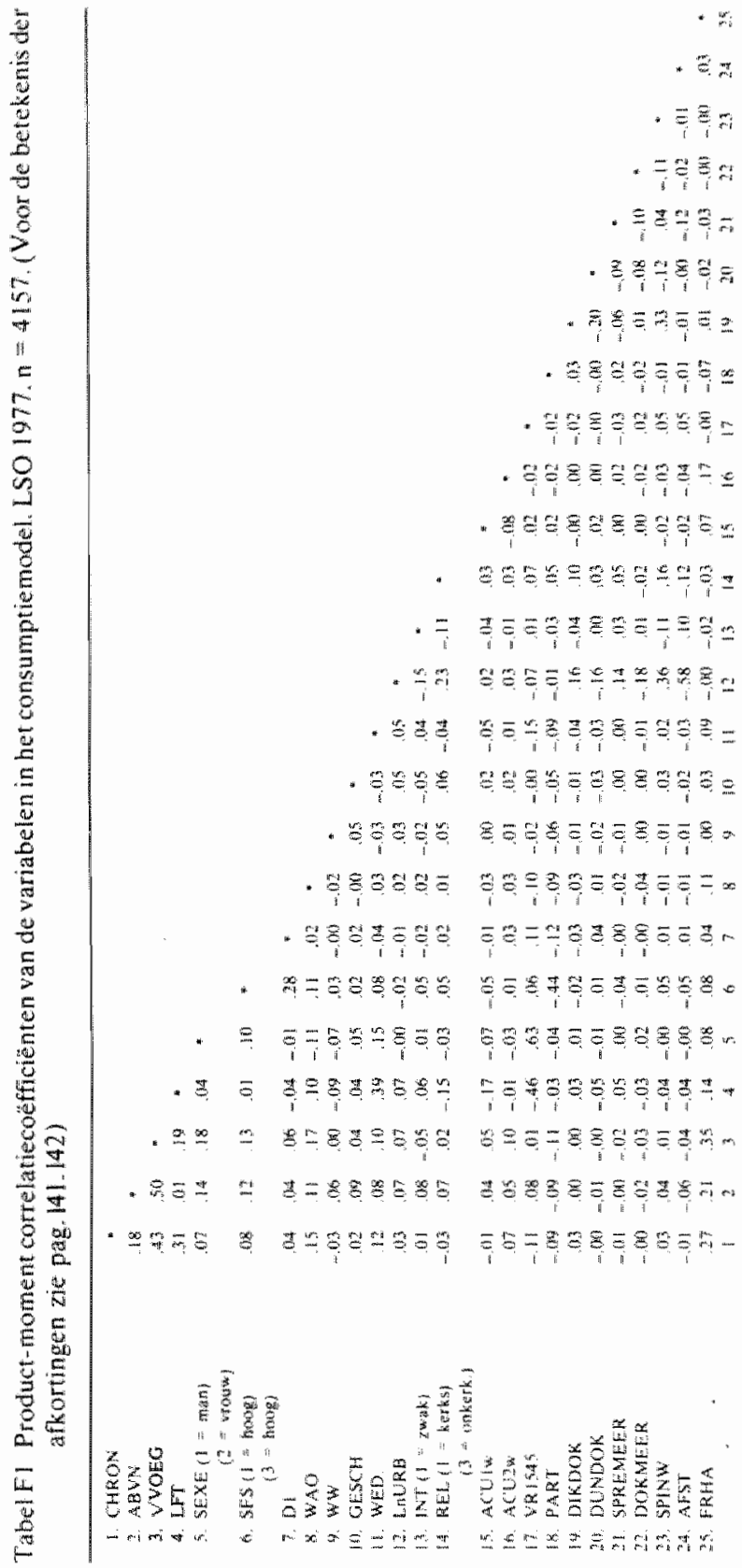




\section{Dankwoord}

Het zou een aardige stelling voor een proefschrift zijn om ervoor te pleiten dat, net als in de filmwereld, alle medewerkers aan een wetenschappelijke productie op de titelrol zouden moeten worden vermeld om recht te doen aan de collectiviteit van zo'n werkstuk. Gelukkig kent een proefschrift de traditie van het dank- of voorwoord, waarin allen die meegewerkt hebben aan het ontstaan ervan genoemd en bedankt worden.

Als eersten dank ik mijn promotoren, Prof. Dr. H. Philipsen en Prof. B. S. Polak, voor hun positieve en stimulerende opstelling, hun waardevolle commentaar en yoor de ruimte die ze mij gelaten hebben om een onderzoek uit te voeren dat ze geen van beiden zelf zo zouden doen. Het is geen onderzoek-met-de-werphengel, maar eerder het droogmalen van een meer om te zien hoeveel vis erin zat en ook de praktische betekenis voor de huisartsgeneeskunde is beperkt.

De referenten, Prof. Dr. C. A. de Geus en Prof. Dr. A. Hazewinkel, dank ik voor de grondige en kundige wijze waarop ze de eindversie hebben bestudeerd en van commentaar hebben voorzien.

Van allen die gegevens voor het proefschrift hebben verstrekt gaat mijn dank vooral uit naar Dr. D. L. Crombie, hoofd van de Research Unit van het Royal College of General Practitioners te Birmingham.

Op indirecte wijze hebben ook Riet Drop en Paul van Leeuwen tot dit proefschrift bijgedragen. De eerstgenoemde door mij op een kneedbaar moment in mijn ontwikkeling als onderzoeker door eigen woorbeeld te overtuigen dat het heel dom van een onderzoeker is om zijn tijd te verspillen aan hectische interview-campagnes als er overal in Nederland (en daarbuiten) gegevens-verzamelende instanties zijn die blij zijn als er iets met hun product gebeurt. De laatstgenoemde als man-op-deachtergrond zonder wiens nuchter advies ik niet aan een wetenschappelijke onderneming van enige omvang zou durven beginnen.

Een zelfide rol vervult mijn collega, Bouke Posthuma, wiens ontwikkeld normbesef op het gebied van het beoordelen en verrichten van wetenschappelijk onderzoek 
van grote invloed op dit proefschrift is geweest en van wie ik bovendien geleerd heb op een genuanceerde wijze te waarderen wat de economie kan bijdragen aan het bestuderen van de gezondheidszorg. Ik hoop dat de periode waarin wij in verband met het vervaardigen van onze proefschriften meer gescheiden zijn opgetrokken dan lang het geval is geweest, binnenkort gevolgd kan worden door een aantal nieuwe gezamenlijke producties.

Dat ik in dit dankwoord pas nu mijn instituut, het Nederlands Huisartsen Instituut, noem, doet onrecht aan de feitelijke invloed op het tot standkomen van dit proefschrilt.

Ik dank de staf en Beleidsraad wan mign instituut dat ik het in dit proefschrift beschreven onderzoek als instituutsproject heb mogen uitvoeren en ik dank Chris Bruins, voormalig directeur, Siem van de Kooij, als huidige directeur en Jozien Bensing als hoofd van de afdeling Onderzoek, dat zij de voorwaarden geschapen hebben waaronder ik het onderzoek heb kunnen volbrengen. Dat zonder Jozien dit proefschrift niet tot stand zou zijn gekomen hoeft geen nadere uitleg.

Mijn collega's van de afdeling onderzoek dank ik voor het strikt toepassen van de instituutsregel dat interne toetsing en kritiek niet rigoureus genoeg kan zijn. Ik mag op deze plaats niet onvermeld laten dat de wetenschappelijke cultuur binnen de afdeling juist dankzij deze kritiek-in-solidariteit onderzoekers van verschillende achtergrond en met verschillende creatieve en analytische vaardigheden tot een hecht productieteam heeft gevormd.

Van mijn naaste collega's wil ik gaarne met name Jan Peter Dopheide en Peter Groenewegen noemen die de verschillende concept- en definitieve versies van de tekst tot en met het gevaarlijke stadium dat de auteur het zelf niet meer merkt als een biadzijde aan de tekst ontbreekt, intensief hebben gelezen en gecorrigeerd.

Het bruikbaar maken van grote gegevensbestanden voor concrete analyse zou mij nooit gelukt zijn zonder de hulp van Hans ten Hoopen, als informaticus verbonden aan het Instituut voor Sociaal Medische Wetenschap van de Rijksuniversiteit te Groningen en van Marie Boschman, als interne steun en toeverlaat. Alleen ingewijden zien in één oogopslag hoeveel kunde en arbeid ten grondslag ligt aan het voor analyse gereedmaken van het in hoof dstuk $1 \mathrm{I}$ gebruikte bestand. Ook het werk van Ruud Severien aan het Engelse materiaal is van groot nut geweest.

I $k$ ben heel blij met de definitieve vormgeving van het boek. Voordat het zover was heb ik Willeke Koster en Marina van Geelkerken het leven zuur moeten maken met het dikwijls opnieuw laten tikken van geheel of gedeeltelijk herschreven vorige versies van het verhaal en dat alles in een handschrift waarin de Nederlandse taal op een niet geheel courante wijze werd vorm gegeven. Voor het omzetten van de getikte tekst in een beschaafd ogende publicatie heeft Mieke Cornelius gezorgd, die het omslag heeft ontworpen en de grafische vormgeving voor haar rekening heeft genomen. Het drukken van het boek was in de vertrouwde handen van Anton Leerentveld. Als het boek door anderen dan vakidioten en zeer naaste familie ter hand wordt genomen, dan is dat aan hen te danken. 


\section{Curriculum vitae:}

Ik ben geboren op 25 juni 1947 te Amerongen. Volgde een Middelbare Schoolopleiding aan het Marnix-College te Ede, waar ik in 1965 het einddiploma gymnasium-B behaalde.

Ik studeerde van 1965-66 Kunstgeschiedenis en van 1966-72 Westerse Sociologie aan de Rijksuniversiteit te Leiden waar ik in 1972 het doctoraal examen (cum laude) aflegde (hoofdvak: empirische en wijsgerige sociologie, bijvakken: medische sociologie en methoden en technieken van het sociaal wetenschappelijk onderzoek; resp. bij de hoogleraren prof. dr. F. van Heek, prof. dr. R. F. Beerling en prof. dr. H. Philipsen).

Vanaf 1 januari 1969 was ik als student-assistent en later als adjunct-wetenschappelijk medewerker verbonden aan het (toenmalige) Instituut voor Praeventieve Geneeskunde/TNO waar ik medegewerkt heb aan het project 'kenmerken van gemeenten en verschillen in afwijkend en ziektegedrag" van Maria J. Drop. Sinds april 1972 ben ik als onderzoeker werkzaam op het Nederlands Huisartsen Instituut te Utrecht, waar ik in de afgelopen 10 jaren gewerkt heb aan onderzoekingen waarin vooral de invloed van structurele aspecten (structuur van de gezondheidszorg) op het functioneren van huisartsen en het gedrag van patiënten onderwerp van studie was en is.

'De Vraag naar Diensten van de Huisarts' is een voorbeeld van een dergelijk onderzoek. Het project makkte oorspronkelijk deel uit wan een samenwerkingsproject tussen het Nederlands Huisartsen Instituut en het Instituut voor Sociaal Medische Wetenschap van de Rijksuniversiteit te Groningen; een samenwerking die heeft geduurd tot het vertrek van mijn Groningse collega B. H. Posthuma. Aan het tot stand komen wan dit proefschrift hebben door het beschikbaar stellen van gegevens meegewerkt:

- het Centraal Bureau voor de Statistiek te Voorburg

- de Research Unit van het Royal College of General Practitioners te Birmingham (Engeland)

- het Nationaal Ziekenhuis Instituut te Utrecht

- de Geneeskundige Hoofd Inspectie voor de volksgezondheid te Leidschendam. 